


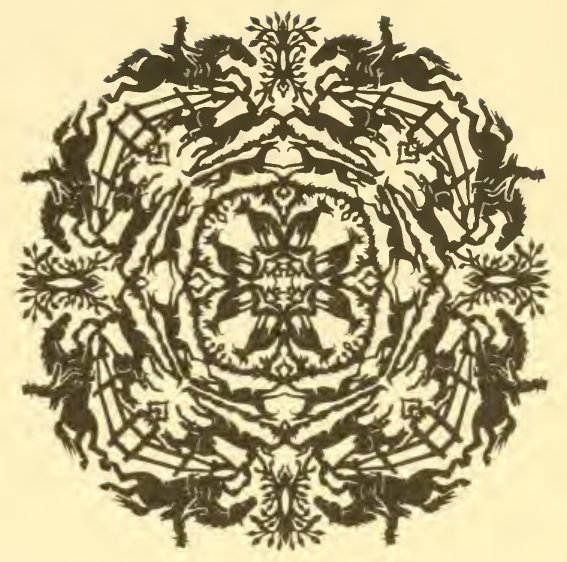

JOHN A.SEAVERNS 
Veternary thbrany

Tufts University

School of vetermary Medicins 200 Westboro Rd.

Worth Griton en $=+2 ? 5$ 

ON THE TRACK OF THE MAIL-COACH 




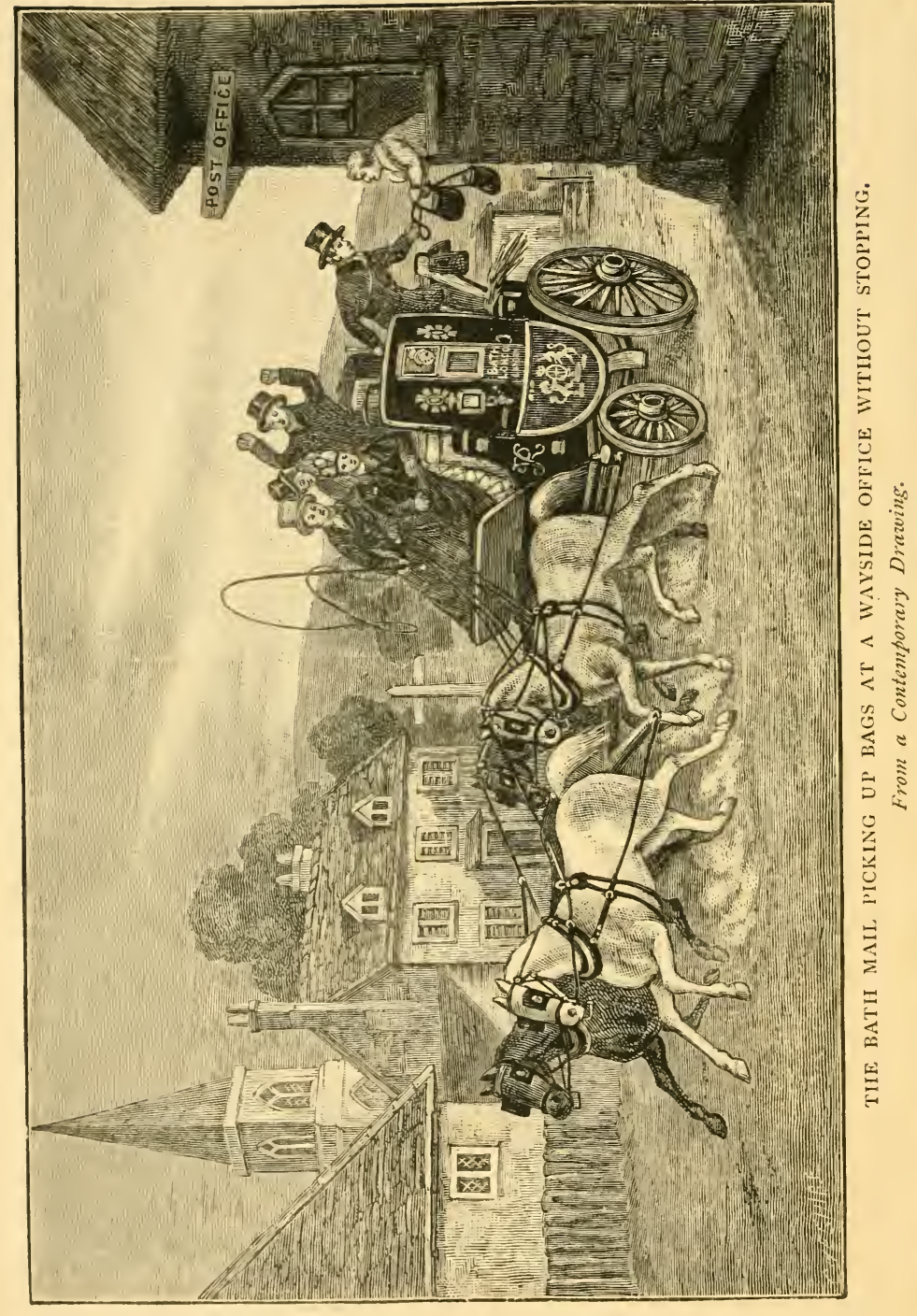




$$
\vdots \quad \rightarrow+1,-1+8=
$$

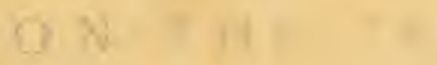

\section{THE MAIL-12OAYITH}

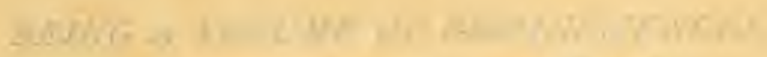

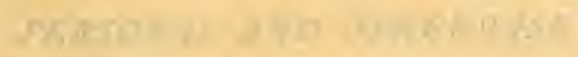
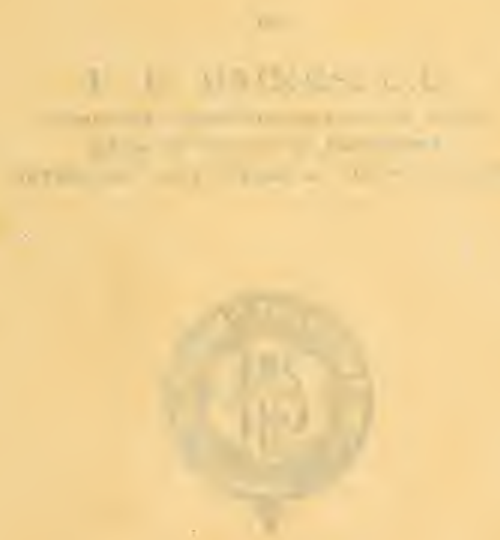

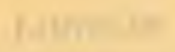

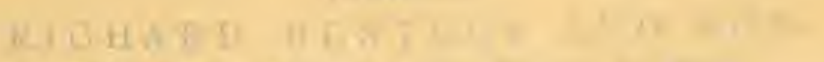

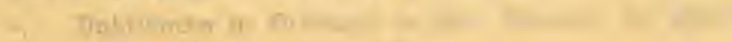





\section{O N THE TRACK}

\section{of \\ THE MAIL-COACH}

BEING A VOIUME OF REMINISCENCES

PERSONAL AND OTHERWISE

BY

F. E. BAINES, C.B.

-SOMETIME INSPECTOR-GENERAL OF MAII.S-

Editor of 'Records of Hampstead'

AUTHOR OF 'FORTY YEARS AT THE POST OFFICE'

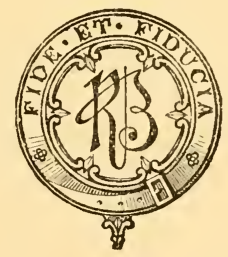

LONDON

RICHARD B EN TLEY AND SON

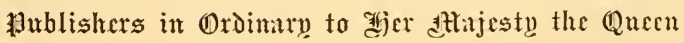

I 895

[All rights reserved] 

THe mail-coach period still has a firm, and possibly an increasing, hold on the public mind, but the officials and others who actually took part in the work of that stirring time-whether on the highroads or within the walls of post-offices - are rapidly passing away.

I have been eager to preserve what those who remain, and some of those who are no more, have told me of matters within their own observation in that remote epoch, as well as what in other ways has come to my knowledge. I have included, too, such of my own recollections, not necessarily postal, as should secure continuity and cohesion in the narrative.

Not all that I had to relate could be included within the limits of 'Forty Years at the Post-Office.' Many omissions, I am but too conscious, still have to be supplied.

There is something yet to be written of interest about the cross-posts and other lines of mail-coach communication, and also about the coaching and posting inns which maintain an existence on the deserted mail-coach roads. 
In this volume I have limited myself, for the most part, to the Track of Mail-coaches, making for the chief ports of the United Kingdom, and I have added some anecdotal matter bearing on the telegraph. Also, having long held certain views with reference to postal and telephonic facilities in rural districts, I have taken this opportunity of giving expression to them.

Here and there I have afforded a glimpse of the complex public work which has been undertaken in the past, and which is still performed with fidelity by provincial postal officials, whose duties do not, as a rule, come under notice, but, as the late Home Secretary is reported to have stated, on the occasion of a Civil Service festivity in June, 1895, are discharged ' in the twilight, through the mist of which the fierce glare of public observation and public applause can rarely penetrate.'

F. E. B.

Bournemouth, November, 1895. 


\section{O N T EN T S}

CHAPTER

PAGE

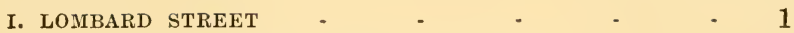

II. THE LIBERTY OF ST. MARTIN'S-LE-GRAND - $\quad 21$

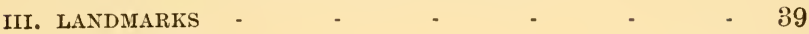

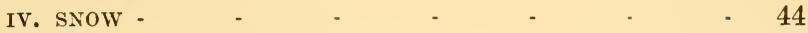

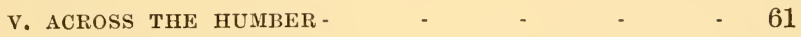

VI. EAST AND SOUTH-EAST $\quad-\quad \quad-\quad \quad-\quad-75$

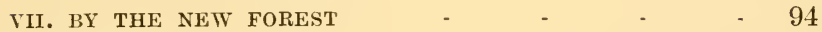

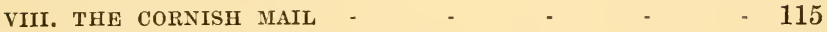

IX. BY SEVERN, TAFF, AND TOWY $\quad-\quad+\quad-143$

X. VIÂ ST. ALBANS $\quad$ - $\quad$ - $\quad$ - $\quad$ - $\quad$ - 163

XI. THE PORT OF LIVERPOOL -

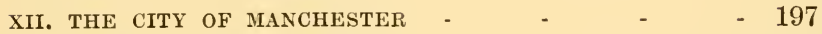

XIII. BOUND FOR THE BORDER - $\quad$ - $\quad$ - $\quad$ - 220

XIV. A JOURNEY DUE NORTH - - - - - $\quad$ - 244

XV. WESTWARD HO ! - $\quad$ - $\quad$ - $\quad$ - $\quad-255$

XVI. TELEGRAPHS ON THE TRACK - $\quad$ - $\quad$ - 281

XVII. PILLARS OF THE PAST $\quad$ - $\quad$ - $\quad$ - $\quad 306$

XVIII. A FUTURE FOR THE GLEBE - $\quad$ - $\quad$ - 325

APPENDIX A

APPENDIX B $\mathrm{B} \quad$ - $\quad$ - $\quad$ -

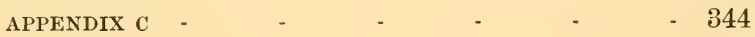

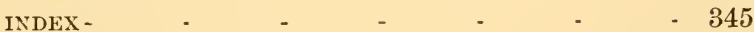





\section{ON THE TRACK OF THE MAIL-COACH}

\section{CHAPTER I.}

LOMBARD STREET.

In Lombard Street, in the reign of Queen Mary, 'a coming event cast its shadow before': at the sign of the Cradle was to be found amongst his books Rowland Hill.

My personal knowledge of the old General Post-Office in Lombard Street, which was the true birthplace of the mail-coach system, is derived from a visit of two hours' duration, paid to a remaining fragment of the original building in the year 1848. So, in order to cover, as best I may, very obvious deficiencies in that respect, I propose to begin at the beginning of all, carrying my readers back even as far as the outbreak of the Great Fire of London in $\mathbf{1 6 6 6 .}$

At that date there stood in the 'Lumbard' Street of 1379, at the corner of Sherborne Lane, the old church of St. Mary Woolnoth. Behind it, within the area enclosed by Sherborne Lane on the one side, and 
Abchurch Lane on the other, was, as I believe, the famous Cardinal's Hat Tavern (though it is proper to add that a recent authority assigns to the corner of a court leading from Abchurch Lane to Cornhill the site of the Cardinal's Cap Tavern) and a host of other tenements. Of these the Great Fire made a clean sweep, stopping short at, or at all events but slightly injuring, St. Mary Woolnoth, while it utterly destroyed the adjacent church of St. Mary Woolchurch Haw.

On the vacant ground, circa 1675, Sir Robert Viner, then Lord Mayor, or his father, built a large house. In it, according to Pennant, Sir Robert entertained King Charles II. With a license which now seems remarkable, the Knight, when the King was about to retire, laid hold of his royal guest and swore, 'Sir, you shall take t'other bottle,' to which the not wholly reluctant monarch rejoined appropriately, 'He that's drunk is as great as a ling.' And, turning back, he did as he was bidden.

About the end of the last century a deep excavation was made near this spot, when, fifteen feet nine inches below the surface, the workmen came on the trace of an old Roman street. Overlying it, and beneath a stratum of brick, two feet thick, were found three inches of ashes.

Curiously enough, I remember that when the foundations were being got out for the new General Post-Office (West), a thick layer of ashes was cut through, as though the buildings then removed had been erected on the burnt remains of the earlier city 
destroyed by the Great Fire. Similarly, in Lombard Street, a great conflagration may have destroyed buildings left by the early settlers.

Against the probability of the Lombard Street discovery pointing to the existence, in the period of the Roman occupation, of a paved city, may be set the fact that when, towards the end of the eleventh century, beams were blown by a tempest from the roof of St. Mary-le-Bow-a church only a furlong or two from Lombard Street-they sank in the soft earth of Cheapside for twenty feet or more, there being neither British pavement above ground nor Roman pavement below to check their descent.

The most recent excavation that I know of near Sir Robert's dwelling was one in 1894, occasioned by digging out the foundations for the new building now in course of construction for the Guardian Fire Insurance Society; but although the workmen dug down far deeper than sixteen feet, no fresh discovery of note was made.

Viner's mansion did not long remain a centre of civic hospitality. There was quickly an end to entertaining monarchs, whether merry or otherwise, or, indeed, guests of any condition. For Sir Robert's convivial visitor saw fit very shortly to play the lively jest of closing the Exchequer, whereby his host lost the not insignificant sum of four hundred and sixteen thousand pounds. No wonder that the 'Prince of Goldsmiths' had to call his creditors together in 1683 , at the sign of the Vine, No. 77 , 
Lombard Street, and satisfy them as best he could.

According to West's splendid work on the 'Signs of Old Lombard Street,'* this same Robert Viner (or Vyner) set up the statue, removed in 1779 , of John Sobieski, on horseback, trampling on the Turk. Times changing, he put a new head on the statue, and made it do duty for Charles II. trampling on Oliver Cromwell, thus forestalling in effect the example of the versatile Vicar of Bray.

By this time the General Post-Office of the day had outgrown the scanty accommodation of Cloak Lane; and early in the last century Sir Robert's house, being available, was acquired by the Government, which transferred the Post-Office to it. To Viner's spacious brick building entrance was obtained from Lombard Street by a gateway, part of the site of which is now occupied by the Guardian Office. The gateway opened into a quadrangle. Like all adapted buildings, it was ill suited for a post-office. A public passage cut through the property from one lane to the other; another open way, which still exists, struck through the very heart of the group of buildings (for there were several) from Lombard Street to what is now King William Street. But at all events here was more space than in Cloak Lane.

In Lombard Street sat Anthony Todd, when, as Secretary of the Post-Office, he drafted the dismissal of Benjamin Franklin from the office of postal agent

* Leadenhall Press. 
for the plantations in North America. Here J. Palmer, of Bath (wherever he may have concocted the historical Bristol, Bath and London essay of 1784), framed his schemes of mail-coach extension, taking not even his nominal masters, the PostmastersGeneral, into his confidence, and leaving no paper trace that I am aware of in the shape of contracts or calculations of his successful, but highly independent, labours.

Here, too, in Viner's mansion, sat, as Secretary for thirty years, Palmer's lieutenant and Todd's successor, the famous Freeling. So, in Post-Office Court, the postal servant of to-day treads classic ground and rubs shoulders, in imagination at least, with the mighty men who, before the days of Rowland Hill, helped to make the Post-Office what it has since become.

Some part of the original building yet remains. When, to anticipate, the General Post-Office was removed in 1829 to St. Martin's-le-Grand, the new street known as King William Street, leading to London Bridge, was cut from St. Mary Woolnoth obliquely across the old site-taking large slices out of Sherborne and Abchurch Lanes, but leaving intact that long, narrow slip extending from Lombard Street by Post-Office Court to the new rectory house of St. Mary's Church, now, like the old one, occupied by the department at a rental of nine hundred pounds a year. That is all that is left of the old Post-Office, which was famous in its day. 
For, although the feats of penny postage are inseparably associated with St. Martin's-le-Grand, the Post-Office had won a name and its way into public favour long before the first stone of the building of 1829 had been laid-long before the public had begun to find the high rates of postage oppressive, and the speed of mail-coaches susceptible of increase.

'The Post-Office,' says Pennant, in his 'London,' ' gives wings to the extension of commerce;' and, 'in the more confined and humble scenes of social life,' wrote the Saturday Magazine of December 1, 1832, ' the posts spread comfort and joy with a liberality which we seldom hear sufficiently acknowledged.' These were welcome tributes to the work of Sir Francis Freeling, freshly transplanted to the new westward office.

Two of the chief features of the inner life of the General Post-Office in Lombard Street (and from 1829 to 1839 of the new office) were taxing and franking. None but the most expert could determine at a glance the rate proper for an inland letter, and just before mail-time, when hundreds of unpaid letters, and letters to be prepaid, would be dropped into the letter-boxes or handed through the window at Lombard Street, it needed a lightning hand to tax them with the proper charge, and mark it in large figures by quill pen on the front face.

Every enclosure, however light, involved an increased charge, and to such an extent was this rule carried that a sheet of paper, containing a protested 
bill of exchange, with a notarial ticket affixed to it, was taxed with three rates of postage.

As for franking, that gave no particular trouble, care at least being taken in the latter days not to pass a pack of hounds or a roomful of furniture, as at earlier periods, and to see that no Member of Parliament exceeded his rightful number of daily franks. This was easy enough, as all letters under frank passed through the chief office. I do not think franks were available by cross-post.

The privilege of franking, Pennant says, was first claimed by the Commons in 1660, and allowed to both Houses by the Crown in the following year. It was asserted, in 1763 , that the loss occasioned by the abuse of this privilege was not much less than two hundred thousand pounds, and in 1839 actually more than three hundred thousand pounds. But, however long franking had been in existence, the 4th of George III., A.D. 1764, is the first legislative enactment on the subject.

By 1802, so far from being alarmed at the abuses and loss of revenue of which the franking privilege admitted, Parliament, with much gusto, and by fresh enactment, allowed each of its members to send ten and receive fifteen letters per diem, weighing an ounce apiece, free of postage.

Franks were necessarily supervised at the PostOffice; once, tradition has it, rather too much so. For the chief officer on duty at the Lombard Street Post-Office on the evening of Tuesday, September 29, 
1812, receiving at six o'clock the London Gazette, containing a royal proclamation for the dissolution of Parliament, conceived it to be his duty there and then to pounce on letters from Members of both Houses put into the post-office that day under frank, and charge them all with postage. With impartial severity, he treated Lords and Commons alike, and letters coming to them unpaid, as well as franked letters, shared the same lot. But this vigorous official was a trifle too smart. Parliament, dissolved on the publication of the Gazette at night, had been a living force at noon, and a frank given then was just as good as it had ever been.

Even Sir Walter Scott, according to a recent authority, seems to have preferred a frank to payment of postage. 'Any parcel,' he wrote to Miss Wagner, from Edinburgh, February 7, 1828, 'will reach me safely, addressed under cover to Francis Freling [sic], Esq., General Post-Office."* This was an expected copy of verses. Letters addressed to Freeling would pass free. If, as Sir Walter's friend, he was merely to have been the custodian of a prepaid packet, 'Care of 'would have formed part of the address. But this was apparently a private postal parcel, enclosed in a cover to an official person, which would thus escape postage.

It is strange that the public, that is, as recipients of letters, put up so long with optional prepayment, which left in many cases heavy postage to be paid * The Nineteenth Century, February, 1895. 
no delivery. Yet for the most part they positively seemed to like it-at any rate, not to object. Not every receiver of unpaid letters, however, appreciated the pleasure, witness Sydney Smith, Combe Florey, September 23, 1829. 'I cannot,' said he, 'from the bottom of Somersetshire, attend in person, as a letter (two and sixpence postage) yesterday invited me to do.'

More than fifty years before Sydney Smith received his letter, Johnson had had an unpleasant experience of the kind. The Doctor, in April, 1776, was called on by the Post-Office to pay seven pounds ten shillings. A friend had sent him from the East Indies a packet by private hand. The ship put into Lisbon, and the Customs authorities there probably did what used to be and perhaps is still done by the British Customs-they seized all post-letters and handed them to the Post-Office.

Ten years later than the pungent rejoinder of the famous divine and wit, Sir John Burgoyne is said to have had a similar experience of high postal charges when in Dublin in 1839. A packet of papers, intended to have been sent as a parcel by mail-coach, was put into the post, and cost him as a letter eleven pounds, instead of perhaps a shilling as a coach parcel.

I do not think that the system of postal accountkeeping was imperfect; on the contrary, I believe it to have been accurate and thorough. But had the plan now in vogue, of daily instead of quarterly 
accounts, been in operation all along, many of the defalcations which occurred, let us say at the end of the last century, would have been avoided, because the daily balances could not have reached considerable figures without attracting attention.

Moreover, bon $\hat{\imath}$-fide errors, in which there was no real defalcation, would have been cleared up in good time. For example, although Daniel Richardson, Postmaster of Chatham, was reported, on July 5, 178., to be seven hundred and thirty pounds in arrear, the debt ran on for several years, until it was discovered, in 1792, that he had not claimed seven hundred and four pounds which was due to him for Returned Letters. At most he owed six and twenty pounds.

The postmaster of a mail port was found to be deficient, when his books were balanced on October 10 , 1785 , in the enormous sum of $₫ 2,591$. However, in the next thirteen years he or his estate paid in large amounts, and so nearly wiped off the indebtedness.

But the bad system of long credits allowed small offices to run up large debts. Balances were advisedly left outstanding, in the expectation that disbursements and remittances would reduce them. They did not always do so. In 1814, the aggregate balance in the hands of the six hundred deputies who then held office in Great Britain alone, was hardly less than a hundred thousand pounds.

No doubt the Civil Service Commissioners now provide a suitable test examination for candidates 
desirous of entering the Accountant's Office. But in the old days a ready way of gauging capacity was to set the youngster to cast long columns of figures, and see if the total brought out agreed with a preascertained sum. One poor youth laboured for hours, and totalled his cast a penny too little. "You are a penny wrong; you must add up the columns afresh,' said the stern examiner. 'Oh, sir!' replied the neophyte, dismayed, ' will it do if I pay you the penny?'

When quarterly accounts were still in vogue, the worthy Postmistress of Cowes followed a capital plan. She had a son in the Bank of England, to whom in due course particulars of receipts and disbursements were forwarded. He made out the accounts, his mother signed them, and no head post-town stood better with the Accountant-General in London than that on the banks of the Medina.

In Lombard Street days, post-offices were frequently handed down from father to son, sometimes even to the third, if not the fourth generation. The late Mr. Norwood, Postmaster of Dover, told me that the Dover post-office had been in his family for a century. The post-office at Liverpool. was in the hands of the Bannings for three generations-at any rate, three successive Bannings held the appointment.

To take an example, in my own native county, the Prices-grandfather, father, and son-have held the postmastership of Ware since 1812. A new plan now operates, which practically throws open every vacancy to the whole service. So the clerk at Penzance 
becomes the Postmaster of Barnet, the Postmaster of Scarborough the Incumbent of Taunton, and family claims fall to the ground.

Still happily, here and there, to the advantage of the State, the old plan prevails-a given locality doing its best to keep the approved stock in its midst. The most thorough-going postal family I know of is that of the present Postmistress of Wetherby. Her mother was postmistress, and her father postmaster, before her. Two of her brothers are in the Morpeth post-office, another brother and a sister are in the York office, and two more of the family, with, I think, a third coming on-i.e., under training-assist their sister in managing the posts and telegraphs at Wetherby itself. Surely that service is not an unkindly one which retains so many descendants of the parent stock.

It is not probable that Lombard Street would have taken kindly to the modern plan which deprives appointments of all sentiment. A worthy but brolien-down merchant can no longer be made postmaster of a principal city. A fit member of the service is not to be brushed aside in favour of a soll who was lucky enough to have had a good father. Todd and Freeling might have echoed the lament of Hindostan. 'The British raj is very just, no doubt,' said a Hindoo gentleman to an English commissioner of my acquaintance; 'but then it's so dull, so monotonous. One knows in the Civil Service exactly what is going to happen next. The chief 
cook of last night may not become the ruler of a province to-day.' No longer is a leaf taken from the book of the Sultan Osman, who is said to have been so impressed by the dexterity with which a gardener planted cabbages that he forthwith appointed him to be Viceroy of Cyprus.

Mail-coach developments, although extensive, had not reached the full at Lombard Street. The greatest achievements were yet to come.

Mail robberies troubled the official mind most. Great care was taken, not always with success, to secure safe stowage of the bags in a special box built into the body of the mail-coach, and fastened by lock and key. The exact dimensions of the mail-box are not on record, but the few guards remaining agree in their recollection that it was three or four feet wide and deep, and perhaps a couple of feet broad.

An old colleague of mine, a great traveller by coach, disdaining all measurements, puts it neatly, that the mail-box would just hold a man doubled up. This would have been an obvious advantage had the duties of guard included the 'doubling up' of a refractory passenger or negligent official, and stowing away the remains out of sight.

The rule was for the guard, when sitting on his perch at the back of the coach, to keep his feet on the locked lid. On the Bristol and Portsmouth mail, it was not unusual, when the box was full, for the guard to sling some bags beside him. No pas- 
senger was allowed to sit at the back of the coach with the guard; that was a rule which was sternly enforced, and admitted of no exception.

In spite of the mail-box being under the feet of the guard, and so, to all appearances, secure at least from attackis by way of the lid, the Leeds mail on one occasion lost sixteen of its bags near Higham Ferrers, by the robber forcing the lock.

If the department was robbed of its bags, it took a lofty revenge on the supposed delinquent, Huffey White, by publishing his description all over the country: "He is marked with the small-pox in large pits deep in the slin; his nose turns up; he has a squeaking voice; he has served on board the hulks; he has been transported for life; he is well known at all the police offices.' Conscious, perhaps, that the hypercritical might regard the terms of this public notice as somewhat deficient in politeness, the department had the grace to add, ' $\mathrm{He}$ is mild in manner, and does not talk much.'

White was a dandy as well as a burglar. He wore a blue under-coat with gilt buttons, white waistcoat, blue pantaloons, and a yellow belcher handkerchief round his neck. Never were mails more genteelly rifled.

If mail-coaches could be despoiled at the halt in towns, what might not be done on the King's highway? Even the plan of protecting the mailriders under a grant of fifteen hundred pounds a year, which early in the century had been obtained from 
the Treasury, did not always prove effectual; indeed, it was not on every ride that protection could be given. As, for example:

'General Post Office,

$$
\text { '16th July, } 1827 .
$$

"WHEREAS on the Night of Thursday the 12th instant, about a Quarter past Ten o'clock, the Driver with the Mail was feloniously stopped by two Men on the King's Highway, between Leatherhead and Dorking, opposite Givon's Grove, when the Men fired two Pistols at the Driver, and severely wounded him.

'A Ramrod was found near the spot, and is supposed to have dropped from the Pistol of one of the Offenders.

'If either of the Persons concerned in the said Felonious Attack, or any Person knowing thereof, will surrender himself, and make discovery whereby the other Offender or Offenders may be apprehended and brought to justice, such Discoverer will be entitled to One Hundred Guineas Reward, and will also receive HIS MIAJESTY'S most gracious PARDON.'

But the most exciting, because the most daring, robbery of all was one that took place much earlier -I think in 1812 - of the down night mail from Lombard Street for Ipswich. The bags were crammed with bankers' parcels, and the thieves found a rich booty in the notes of the private banks at Hadleigh, Manningtree, Ipswich, and Woodbridge. A reward of no less than one thousand pounds was offered, and the theft was long a stock story in the Post-Office.

I cannot claim that it was in a mail-coach, but certainly in a coach of some $^{\circ}$ sort, that a lady passenger strongly advised a gentleman-a stranger, also riding inside - to put, for security against robbers, all the money he had, amounting to ten guineas, 
into his right boot. When on Hounslow Heath, Finchley Common, Hartford Bridge Flats, or where not, the customary highwayman appeared, presenting pistols through the coach-window, and demanding of the lady her money or her life. She, protesting poverty, promptly advised inspection of the gentleman's right boot. As a consequence, the highwayman rode off ten guineas the richer. Upbraidings within the coach no doubt followed.

Next day, at the inn, the lady, then in safety, explained her strategy. She had had a thousand pounds in her pocket, which she saved by her ready wit, and out of it handsomely presented the gentleman with a hundred pounds, in compensation for his loss and mortification.

The guards were well armed, but whether firearms were ever actually used in repelling an attack on the mail I cannot say, although in Lombard Street days they were, no doubt, so used now and then. That the display of arms has. warded off an attack more than once is certainly the case. Mr. Thomas Doughall, now living at Carlisle, was one of the last mail-coach guards appointed. He entered the service in 1839, at nineteen years of age. His defensive equipment, when on duty, consisted of a blunderbuss and a pair of pistols. Once a party of sailors commenced stoning the coach, and then attacked it; but when the guard, having produced his artillery, was preparing to fire, they caught sight of his warlike paraphernalia and decamped. 
I have heard of but one accident resulting from the arming of mail-guards, and that was in Scotland in the old days-in 1836. Strange to say, it occurred at a wedding. The guard of the Aberdeen and Ballater mail-coach, being off duty, incautiously lent his blunderbuss to a friend for the purpose of firing a festive salute. The friend fired not wisely but too well, and blew off his own hand.

Colonel Corbett, however, cites another mishap, which ended fatally, at Ballina in Ireland. The blunderbuss of the Sligo mail accidentally exploded, and cost a poor countryman his life.

By degrees the security of the mail became assured. Had the race of Turpins, Abershaws, Nacheaths and $\mathrm{Du}$ Vals survived, it would have found the work of the road grown too hot for comfort by the time that Lombard Street ceased to be the focus of mail-coach administration.

That time was approaching, but many years passed before it was reached.

A Cabinet Minister once told me that experience showed that thirty years were needed to carry out a great public reform -in maturing opinion, and getting the Government of the day to act. This particular reform took up just forty years. In 1789 it was mooted, in 1814-15 inquired into, in 1829 accomplished.

Never was a new and commodious structure for postal business more urgently required.

The Lombard Street post-office was by no means 
insignificant in size. It cost annually four thousand pounds to repair, a thousand to warm, and five thousand to light. Most of the business was done with the aid of oil-lamps, partly because almost every letter had to be held up against a bright light for the detection of enclosures, and partly because the rooms were rather dark. But it was a miserable building in which to lodge a great Government office. Sir John Tilley cannot yet have forgotten its discomforts. His office, when he was very young, was, I once heard him say, the disused litchen of the old rectory-house of St. Mary Woolnoth, which the PostOffice rented, and which, prior to 1832, faced Sherborne Lane, south of the church.

Houses were also taken for postal purposes in Abchurch Lane, in order to ease the strain; but these extensions were to little purpose. The mailguards' room was not twelve feet square; it had to receive, every night, eighteen guards, as well as twelve assistants, with tools, bars, and great-coats. There was no place for the deposit of firearms. The Comptroller had to share a room with his clerks. When persons preferred to speak to him alone, the clerks had to retire, quitting their own work and interrupting that of others.

The housekeeper used two small rooms-one without a fireplace, up a wretched staircase, 'narrow and worn out,' leading to second and third floors above. Had the building eaught fire below, the whole establishment upstairs would probably have been swept 
away without hope of rescue. In one of her rooms the housekeeper, as well as her family, lived; in the other, she cleaned, inter alia, a hundred candlesticks, of which process it may be assumed the dwellers above became daily aware.

The letter-carriers' room, with eighty men in it, was ' unwholesome and offensive.' Daniel Stow, the Superintending President, said the Inland Office was too small by half. The crowded state of the three great sorting offices rendered necessary an enormous consumption of vinegar for fumigation, such being the approved antiseptic of the period.

Outside it was no better. The public found themselves in tight places. To gain access to the unpaidletter posting-box and the paid-letter window, they had to struggle up long passages, six feet wide from Lombard Street, five feet wide from Abchurch Lane, and four feet wide from Sherborne Lane. Between six and seven o'clock in the evening, from eight to ten thousand persons streamed into these culs-desac. Robberies and rows, despite the constables, flourished.

For the mail-coaches (seventeen were running out of London in 1814, but seven only started from Lombard Street) there was scarcely standing room. Two coaches had to be loaded up in Cornhill and Bank Street, and six at the Gloucester Coffee-house, nearly three miles from Lombard Street.

Public traffic during the despatch of the night mail had to be stopped. Sherborne Lane, on the 
west side of the office, was crooked, inconvenient, and only ten feet wide; Abchurch Lane, on the east side, little better. The coaches had to drive over the pavement in passing each other. Finally, the Lombard Street office lay east of Cheapside, while very nearly three letters to one were delivered to the west of it.

Parliament could not shut its eyes to the serious inconvenience which the public sustained. It determined to remedy the matter, and appointed more than one Select Committee to examine the question. To rebuild on the Lombard Street site was to effect but a partial and temporary remedy; to move to the northward, as had been proposed, was against the general drift of correspondence; to build a new post-office a mile to the westward seemed the true solution. That was the course agreed upon.

Fourteen years later-i.e., on September 29, 1829 - to the joy of all who served under its roof, bidding farewell to Lombard Street for ever, Freeling carried the staff and the secretarial chair to what the Saturday Magazine has described as 'Smirke's magnificent building-the new and spacious office erected for the purpose, on the site of an ancient college and sanctuary in St. Martin's-le-Grand.'

The mail-coaches had yet some years to run before there came the beginning of the end. With the new life which removal to the new building seems to have inspired, all previous efforts were rivalled and even surpassed. 


\section{CHAPTER II.}

THE LIBERTY OF ST. MARTIN'S-LE-GRAND.

IF I can only boast of two hours' acquaintance with the General Post-Office in Lombard Street, at any rate $I$ have spent twenty years under the roof of its successor, and twenty more within the walls of the second post-office in the Liberty of St. Martin's-leGrand. As for the third office, just completed, rooms were prepared in it for occupation by the branch of the department in my charge, but, although I saw the building grow up under my eyes, I have never set foot within its walls.

The selection of St. Martin's-le-Grand as the site of the new Post-Office, gave great satisfaction to owners of property there, and was approved on all hands. It enjoyed, justly enough, the reputation of being one of the worst parts of London. Those who recollect, as I do, Seven Dials in its palmy days of dirt and dissipation, of racket and rascality, will have no difficulty in realizing the state of some parts of the Liberty of St. Martin's-le-Grand in the first years of this century. 
Time was when at the Cheapside end sanctuary could be found. The aroma of that delectable period still hung around the place. The respectable ratepayers formed themselves into a vigilance committee-so little was the King's peace kept-and paraded the Liberty until two o'clock in the morning. John Grant, who lived next door to the watch-house, testified that he could not sleep for the noises at every hour of the night. George Lee, who had resided at 39, St. Martin's-le-Grand for thirty-two years, said the houses were so old that only six had been rebuilt since the Fire of London, a hundred and fifty years earlier. Parliament made a clean sweep of rookery and court.

The site settled, what about the building? The Select Committee considered it indispensable that a competition of architects should be invited, and, baleful suggestion from the Post-Office point of view, that the Office of Works and Buildings should be called in to advise.

'An office,' said the committee, 'for the receiving and delivery of letters which should be concealed behind a front fit for a palace, and flanked by triumphal arches, would present an incongruity no less offensive to good taste than inconsistent with rational economy.'

This was, I fear, a fling at poor Mr. Kaye, architect or buildings-surveyor of the Post-Office, who was really a very capable person, and had prepared plans and elevations. Smirke came to the front. He 
began to build - at all events to prepare the groundin 1818 , but eleven years elapsed before the new office was ready for occupation.

The building needs no eulogium, either as regards beauty or design; but I doubt if it realized quite the severe simplicity which the committee of 1815 desired. It certainly adopted in principle a main feature of Kaye's plan - a large court within for public use. 'A central hexastyle portico of the Ionic order, the columns fluted, the frieze plain, the cornice with appropriate ornament of dentals in its bed mould,' scarcely reads as though 'ornamental decorations introduced for the mere purpose of embellishment,' which the committee appeared heartily to detest in Kaye, were wholly avoided by Smirke. The total cost of site and building was about $£ 330,000$.

There might be amongst architects and men of taste differences of opinion in regard to style, elevation and disposition of space in Smirke's structure, but there was none on the cardinal point of providing ample means of access for the mail-coaches. The prime consideration of facility of entering, loading up, and departing, stamped itself on the accepted plan, and may any day be traced in the drive which, with the street, goes round the building and expands into an open courtyard at its northern extremity.

The up-coming coaches entered at the south end, discharged their mails at the north end, and, such as Sherman horsed, drove straight into the Bull and Mouth yard opposite. 
Now began a settled course of acceleration of pace and improvement of vehicle and service. The Duke of Richmond, as Postmaster-General, turned to the work with energy and skill.

In 1834, M. de Haussez, a French politician, published a long account of his visit to England in the previous year. The labours of the Post-Office had already borne fruit. He described the English mailcoach as an elegant carriage, and admired alike horses, harness, and roads. He thought, however, that the French diligence got over the ground as quickly as the English coach. But it was found that while the English mail ran at an average speed, including stoppages, of nine or ten miles an hour, the malle poste in France travelled only four or five miles an hour, and at its best six.

All the same, the service was not without its hostile critics. The foreigner, indeed, gave us better words than our own familiar friends; inasmuch as the Quarterly Reriew, in 1837, when locomotion by road was at its best, took a gloomy view of the dangers of stage-coach, if not of mail-coach travelling. It wrote :

' Iet notwithstanding the moral improvement of the drivers, the improved construction of the coaches, and the improved state of the highroads throughout the kingdom, stage-coach travelling is more dangerous than it ever was before, owing to the unmerciful speed of the swift coaches and the unmerciful loads which are piled upon the others, like Pelion upon Ossa, or suspended from them wherever they can be hung on.

" Coachman," said an outside passenger to one who was 
driving at a furious rate over one of the most mountainous roads in the North of England, "have you no consideration for our lives and limbs?" "What are your lives and limbs to me?" was the reply. "I'm behind my time!" '

The Quarterly Reriew referred not without reason to unmerciful speed and heavy loads. England was said to be the Inferno of horses.

It is no doubt true that it is the pace rather than the distance which kills. In Persia it is, at least in the beginning of the century it was, the habit of a chupper, or express horseman, to travel enormous distances, even from Teheran to Bushire, which cities are seven hundred miles apart, without change. Stages of forty miles were not unusual. But then the pace was an even four or five miles an hour, and at that rate sixty or seventy miles could be traversed daily for several days in succession.

With us, for the mails, at any rate, short stages of eight or at most ten miles were the rule, but the pace was in many cases very great, the roads sometimes deep, and the hills always trying.

Even now, the stages of some of the heavily laden parcel-coaches are longer than desirable; as, for example, from Barnet to Welwyn, fourteen miles; Welwyn to Henlow Station, fifteen and a half miles. However, the pace is moderate, the running time for the last-mentioned stage being two hours and three minutes.

The Reriew was not alone in its strictures. Anstey's 'New Bath Guide' had already furnished, in its 
edition of 1830 , a lively picture of stage-coach travelling on the Great Western Road :

'Even so late as 1804, the writer of this note travelled from London to Derry Hill-a place between Chippenham and Calne -on his road to Bath in a four-wheeled lumbering carriagea mulish vehicle, between a broad-wheeled waggon and a stagecoach-in company with ten inside, sixteen outside, including guard and coachman, and with baggage piled up full six feet above the roof. This compact but discordant mass of live and dead lumber, regularly booked but not legally ensured, left London about three o'clock in the afternoon and was broken down at Deiry Hill at nine o'elock the following morning, having moved over about ninety miles of ground in eighteen hours. The smash was tremendous-the screams, the groans, the exclamations, the curses, and the prayers of twenty-six persons, were various, discordant, and even ludicrous, but distressing. Some suffered severely, some trivially, and others not at all. The note-ist and two other persons walked to Chippenham, about two miles distant, hired a post-chaise, drove to Bath, and compelled the coach-proprietor to pay for the same. Other passengers were confined for some weeks at the White Hart Inn, Chippenham, by bruises or broken limbs.'

Whatever may have been the actual state of mailcoach travelling, there is no doubt that the PostOffice, stimulated perhaps by Committees of Enquiry, strained every nerve to bring about perfection.

It was necessarily a nice question with the department, in 1835, whether new mail-coach services should be put up to public competition or arranged by agreement with persons of known substance and ability. Efficiency was best secured by the latter course, but economy and the task of procuring the assent of the Treasury to fresh expenditure pointed to the expediency of adopting the former. 
' The first feeling of Mr. Palmer, with whom mailcoaches originated,' wrote Sir Francis Freeling, 'was to get the public service done well-to apply to the persons most competent to secure all the advantages of a firm and vigorous execution of his plans. I was brought up in the same school, and as far as the matter has rested with me, I have always pursued the same principle.' But Freeling's influence then was on the wane, and, however sound his reasoning might be, it did not follow that it prevailed.

In the Post-Office nowadays open competition is the rule; but it is not clear to me that it has always secured better results than were obtained under Palmer and Freeling's plan.

It may be mentioned, in passing, that the Bristol and Portsmouth coach was established under Freeling's immediate superintendence about the year 1786. As Palmer's lieutenant, and inspired by the vigour of his chief, he travelled by the coach on its first journey. Fifty years later, within three weeks of the date when the pen was laid aside for ever, Sir Francis was still recommending accelerations of what he termed 'a child of his own.'

The price to be paid for mail-services depended to a great extent on the number of passengers allowed to be carried.

There was naturally a struggle in the official mind between cheap contracts but many mail-coach passengers, and fewer passengers, greater swiftness and punctuality, but higher payments to the contractors. 
The struggle, I have little doubt, goes on still in mail-train questions, inasmuch as numerous passengers and heavy luggage are sore hindrances to punctuality.

It is not easy, however, to fix with absolute precision on the number of passengers, exclusive of coachman and guard, actually allowed to travel by the mail. In the old fast post-coaches only four passengers, all insides, were carried; and on the mail-coaches, in 1792, Mr. Herbert Joyce* speaks of five being allowed, four inside and one outside, presumably next the coachman. He adds that 'in 1821, as in 1836, the number of passengers by a mail-coach was limited to four inside and four out'-total eight-but on some coaches no more than three outside passenger's were allowed-total seven. In 1832, the Saturday Magazine pictorially represented one outside passenger, and assuming four passengers inside, the total would be five. In Parliamentary evidence, in the late twenties, I find the number spoken of as limited to six.

The Liverpool and Preston fast mail, running in the thirties, was built to carry only six passengers. De Quincey speaks of seven, the four insides being indignant at the presumption of the three outsides seeking to dine with them. A surveyor's clerk of 1838, who travelled freely by the mail, tells me the numbers were: one on the box, two behind the coachman, four inside-total seven. A print of the Quicksilver shows a like number.

* 'History of the Post-Office,' H. Joyce, C.B. Bentley, 1893. 
Mr. M. J. Nobbs, reputed to be one of the very last of the mail-guards, writes that:

'The mail-coach I travelled on was allowed, during the last ten years of my service on it, to carry eight outside and four inside passengers-twelve; instead of three outside and four inside passengers-seven; as was the case when I first started work as a mail-guard, i.e., in 1836.'

So far as regards England and Wales. In Ireland, the guard of the Dublin and Wexford mail-coach puts the number of passengers carried by his mail in the last days before the railway at twelve-four passengers inside, and eight outside.

The explanation of these varying figures, I have little doubt, is that the department by degrees gave up or relaxed its limitation of passengers, and so got its mails carried at less cost. It certainly set the example of swift coaches, and cultivated the taste for travelling. But, whatever the cause, the growth of activity on the road during the twenty years which preceded the opening of the railways was phenomenal. In 1815 , the net revenue produced by the stage-coach duty (including, of course, that paid by the mailcoaches)--twopence per single mile run-had been $£ 218,000$; in 1825 , just before the move from Lombard Street, it was sixty-six per cent. more; and in 1835 , six years after it, the revenue amounted to within a fraction of half a million sterling, equal to an increase of a hundred and twenty-eight per cent. on the revenue of 1815 .

If William Chaplin was by far the largest coach- 
horse proprietor in London, especially when he went into partnership with Benjamin Worthy Horne, Edward Sherman's name ought to be familiar in the postal mouth as a household word, if only because his London horses stood in the Liberty, on the very spot where the Post-Office has now concentrated its administrative organization.

Where the mail-coach horse mangers ranged, the chariot-horses of the Romans may have fed; for underneath was the foundation of the old wall of London, and where Sherman's horses pawed the ground, on being put to, I have picked up a tile of, perhaps, A.D. 306-when the Romans rebuilt and walled London-with the broad mark of the moulder's thumb yet imprinted on the clay.

Sherman at the outset was a stockbroker; then he married in succession three rich wives; built, or altered, the Bull and Mouth, and stabled his horses beneath it. With plenty of capital and a fine head of cattle, he sent coaches out of his yard in 1836 which were models of construction and finish. The night mails to Glasgow and Leeds worked, of course, to a Post-Office time-table; but with the day coaches Sherman had a free hand, and the ground flew beneath his horses' hoofs.

Then was the coaching world astonished by the spectacle of journeys performed by the day mail to Birmingham in twelve hours ; to Exeter, by the flying Telegraph, in $17 \frac{1}{4}$ hours; to Leicester in $11 \frac{1}{4}$ hours (the boasted 'elegant post-coach' from the Swan with 
Two Necks, Lad Lane, of 1812, carrying only inside passengers, took fourteen hours in running to the George, in the Haymarket at Leicester); to Manchester in $17 \frac{1}{4}$ hours; to Portsmouth, to Woodstock, and to Worcester, at a noble pace; and to Shrewsbury, by the memorable Wonder, in sixteen hours.

It was Sherman, according to Colonel Corbett, who made the gallant attempt to run the new railway off the road, by means of the Red Rover, from the Bull and Mouth to Manchester, in the winter of 1837. But the sentiment which may still induce the traveller to prefer, in the summer solstice, a spin of a dozen miles over a fair rolling country behind four 'prancing tits,' to being drawn by the iron horse, was not long proof against the blandishments of a spacious cushioned compartment, for a six or eight hours' journey by steam, as an alternative to an eighteen hour's' journey on the top, or even in the inside, of a coach at any time of the year; and Sherman, with his Red Rover, fared no better than Don Quixote with his wind-mill.

The Marquis of Conyngham, the most transient, probably, of all Postmasters-General, retired for the second time on May 30, 1835, after a tenure of office of only twenty-two days, and so made way for Thomas William, Earl of Lichfield, who, no less than the Duke of Richmond, bent his mind on mail-coach development with vigour and success.

Lord Lichfield did his part well. Twelve new coaches having been put on by his predecessor, he effected accelerations, and put on more new coaches 
still, amongst others the Gloucester and Brighton mail, which commenced running on August 16, 1836. It left Gloucester at two a.m., and reached Brighton (1.52 miles 6 furlongs) at five p.m., starting from Brighton on the return journey at seven-thirty a.m. As this was about the last mail-coach established, some details may not be out of place. It ran at ten miles an hour, and cost-at threepence a mile for the horses, at $2 \frac{1}{8} d$. for the coach itself, for tolls at bridges and for wages of three guards-in the aggregate, $\approx 1,354$ a year.

Some idea of the postal defects it was designed to remedy may be gathered from the fact that the towns of Gloucester and Chippenham, distant from each other only thirty-five miles, were five days' post apart.

So much did passenger traffic hinge on convenience of hours, that, had the mails been despatched from Gloucester at five a.m., rather than two a.m., the contractors would have accepted nearly five hundred pounds a year less from the Post-Office.

Such accelerations as had been achieved cheered the heart of the dying Secretary. It had ever been with him, he wrote to Lord Lichfield, 'a favourite object to put the great communications between the principal towns on the best possible footing, and what his assistants had accomplished went far towards that object. The important measures shaped were, Freeling declared, ' in pursuance of the earnest desire we have all felt to improve the posts of the country.' I know not if these loyal and kindly words were the 
last that he wrote, but a few days later Secretary Sir Francis Freeling was dead.

Freeling's death took place in London on July 10, 1836. For a few weeks postal affairs were administered by his eldest son, George Henry, who held the office of Assistant-Secretary. A vacancy soon occurring in the Commission of Customs, Sir George was appointed to it, and the Freeling dynasty, at the PostOffice, came wholly to an end.

The name itself survived within the walls of the department until a few years back, directly in the person of the late Mr. F. H. Freeling, Surveyor of the department in the Channel Islands, and indirectly in that of Mr. Freeling J. Lawrence, an esteemed official who, after long service, has retired into private life.

A part of my apprenticeship to secretarial work in Smirke's Post-Office was served under a master of his craft, whom I will call $\mathrm{X}$, and who sat in a room, shared by two assistants, which looked out, at the back, on Foster Lane. One of these- $\mathrm{Y}$-was of a theatrical turn, and the other was, I think, the son of a literary man. Both were jovial spirits. Of them there was related to me many years ago a mirthful incident, the account of which, no doubt, has received some embellishments in repetition.

One day the chief was absent. The two assistants, as the day wore on, whiled away the time by bombarding each other with official books and bundles of X's office-papers. It was hot weather, and the windows were open. At length, by mischance, out of 
a window flew an Imperial Calendar, marked with the name or number of the room. It fell in the narrow lane, at the feet of a passer-by, who speedily appeared in the Secretary's office, purple with anger.

$\mathrm{He}$ was shown into X's room, where $\mathrm{Y}$ (who was the real culprit) received him with gravity, and deplored the occurrence, which was attributable to a wild young married man (with a wife and three little children), named $\mathrm{X}$, who had that moment left the building. $\mathrm{Y}$ would at once write a minute to the Postmaster-General, and advise his dismissal. On this the visitor relented, and protested that he would, in that case, withdraw his complaint, as it would be lamentable if the youthful wife and little children suffered for a giddy act of the young father. Mr. X, he advised, should be rebuked, and cautioned as to his future conduct. A fatherly eye ought to be kept upon the young and thoughtless fellow.

At first, Y, secretly overjoyed at the turn affairs had taken, professed himself reluctant to adopt this course, from a high sense of public duty; but, at length, on renewed appeals, he magnanimously gave way. So nothing more was heard of the unlucky shot into Foster Lane, and $\mathrm{X}$ to this day, in his retirement, is not aware of the goings-on of his satellites on that eventful afternoon.

There was another incident.

When salaries were paid quarterly rather than monthly, as at present, some of the younger men, and perhaps even the older ones, became rather 
inadequately supplied with cash in the third month of the quarter, and during that month tradesmen's bills were paid with possibly somewhat less promptitude than at other times. The creditors knew how the land lay, and when cash was available.

Once, on pay-day, a tailor appeared at the PostOffice, peremptorily demanding payment from a customer. He would listen to no excuse or delay, and vowed that he would not leave his debtor's side until he was paid.

'Oh, very well!' said Z, who was a humorous youth but little disposed to pay bills. 'If you must have your money, come with me to the next room.'

In that room was a descending lift, which to this day is always in motion. Z lightly sprang upon it, and, waving his hat to his amazed and bewildered creditor, bade him a graceful adieu, and disappeared from view in the depths below.

Indeed, not a few of my colleagues, as the quarter advanced, seemed to be in the condition of the sprig of fashion who, when asked what was the cause of his neglecting to pay his debts, replied: 'Inadequacy of means.'

Tailors were, however, not always so aggressive as in Z's case. The clouded brow of a young man, who has since risen to distinction in paths outside the Post-Office, once attracted my attention. He explained that his tailor had had the audacity to request payment of an account. The wealth of my young colleague chiefly lay in being well connected and 
having a good figure. 'Tell me,' said I next day, 'what happened.' 'Of course I made the tailor apologize. I said to him, "Look here; if this is repeated, I shall take away my custom.", "What did he say to that?' 'That he was very sorry. It was quite an oversight, and should not happen again. I was not to think of my bill (which I certainly shall not), and would I let him measure me for a new coat?'

The business of the Post-Office grew with great rapidity. Efficient service, low rates of postage, increase of population, activity and extension of trade -all told their tale. Freeling was dead, Naberly had retired, and Sir John Tilley had succeeded Sir Rowland Hill. He cast his eyes on the western side of St. Martin's-le-Grand. In due course a second General Post-Office, from the design of Mr. Williams, of the Office of Works, arose in the Liberty.

The late Mr. Ayrton, Member of Parliament for the Tower Hamlets and First Commissioner of Works, laid the foundation-stone in the late sixties. He was not prone to indulge in ornate elevations. The Committee of 1815 would have found him architecturally a man after its own heart. I recall the gravity with which, at the little ceremony of stonelaying, he declared that he aimed at constructing a building for use rather than for show. Success in both respects marked the effort.

Williams's office was a more costly affair than Smirke's. The social atmosphere of the Liberty had been purified; rents as a consequence had risen. 
Property on the one side cost almost double what it had fetched on the other. The building itself, however, was cheap enough. 'Site and structure came to rather more than four hundred thousand pounds.

Smirke's office is still, in spite of cruel gashes, as solid as a rock; its successor, as would be expected, scarcely less so.

But when Sir John Tilley laid his plans, postal telegraphs had hardly loomed on the horizon. Fawcett was yet to come with his vivifying influence - the parcel post, aids to thrift, and other beneficent schemes. Lefevre was still to arise and push to completion his dead friend's ideas, and engraft on the department far-seeing plans of his own. More space was soon needed.

All eyes turned to the Bull and Mouth, which had been largely rebuilt, and named the Queen's Hotel. It was highly prosperous, and somewhat difficult to acquire. But money can do most things. The PostOffice stepped forward and bought it, and built upon the site, from the design of Mr. Tanner, the third office in the Liberty, which is now in occupation and known as the General Post Office (North). It cost, in land, compensations, and structure, four hundred and twenty thousand pounds.

My official room, on the first floor of the northeastern angle of the General Post-Office (West), commanded a full view of the hotel. I saw the process of demolition from first to last. The old coffee or smoking room at the back was, I am 
tolerably sure, the coffee or commercial room of Sherman's time; and that and some of the bedrooms, without fireplaces, which were survivals of the original building, gave an idea that, as measured by modern wants, the old-fashioned inns were not without their discomforts. Rats were plentiful.

As signs and relics of the old Bull and Mouth, the modern Queen's Hotel bore on its front wall two enormous tablets; the larger, sixteen feet high and eight feet wide, richly moulded, contained the following inscription :

\section{'Milo, the Cretonian,}

An Ox slew with his fist, And ate it up at one meal.

Ye Gods! what a glorious twist!'

On the smaller (four feet high and five feet wide) figured a fine young bull, modelled apparently on Paul Potter's immortal work at the Hague, and beneath it

- the grotesque masque of a himan mouth. These tablets were presented in 1887, by the PostmasterGeneral (the Right Hon. H. C. Raikes, M.P.), to the Guildhall Museum as memorials of an old City inn.

Smirke's office opposite regulated the full flow of mail-coaches for exactly nine years. Then the tide slackened. Yet until 1854 a trace of the old days survived in a branch of the department styled the Mail-Coach Office. One of its functions was to determine distances. 


\section{[ 39 ]}

\section{CHAPTER III.}

LANDMARKS.

Nот indeed all, but many of the coach-roads on the northern side of the Thames were measured from 'the place where Hicks's Hall formerly stood.'

It would seem that I am not the only native or parishioner of Chipping Barnet who has aimed at verifying the site of that and other famous places in the Metropolis, from which distances along the coachroads were as a rule reckoned.

Knight's 'London,' of 1841, devotes part of a chapter on suburban milestones to the fruitless travels of Jedediah Jones, a schoolmaster of Barnet, in attempting to discover Hicks's Hall. Jones, after a weary day which yields no result, spends his penultimate shilling on a frugal meal, and his very last on the guard of the Holyhead mail, in obtaining a lift outside the coach from Highgate to Barnet.

I have been more fortunate. Park's ' History of Hampstead' and some other publications clear the matter up beyond a doubt. Besides, a wall tablet still indicates in some detail the site of Hicks's Hall. 
Six or eight places have been accepted by various authorities as the points from which measurements were made, viz.: for the eastern roads, Shoreditch Church and the Standard in Cornhill; for the southeast, the Stone's End in the Borough, which I take to have been the south end of Blackman Street, near the King's Bench Prison; for the south, perhaps the Obelisk in Westminster Bridge Road; for the western roads, Hyde Park Corner; and for the northern roads, St. Giles's Pound, which stood near St. Giles's Church; Holborn Bars, and notably Hicks's Hall.

Of these, the most ancient was probably the Standard in Cornhill; the best known, at any rate in the Post-Office, Hicks's Hall.

Shoreditch Church stands in the High Street, exactly opposite Old Street, where the Kingsland Road and the Hackney Road conspire to make, with the other two, what is still known in rural parts as a four-want way.

The Standard in Cornhill dated from a very early time indeed. It was an ingenious, but imperfect, contrivance for receiving Thames water, raised by mere pressure of the tide. Sometimes the Standard overflowed, at others it ran dry. Known indifferently as the Carrefour, Foure Spouts, or Water Standard, it stood at the intersection of Leadenhall Street, Cornhill, Bishopsgate Street, and Gracechurch Street. (In the later great fire of 1765 , by the way, all these four corners were alight at the same time.)

Eventually, the Standard became a nuisance, and 
was discontinued July 10, 1671, one Nicholas Duncome being paid fifteen pounds ten shillings for clearing it away. But, as in the ease of Hicks's Hall, distances continued to be reckoned from its site for a century or more after the column had been taken down.

The Hall, dating from 1610 or 1612, was planted in an open space next St. John's Lane and St. John Street, on the southern edge of Clerkenwell parish.

It was built by Sir Baptist Hicks (or Hickes), partly for the use of the justices at Sessions, and partly as a Bridewell, or house of correction. It fell into ruin, and was replaced, in 1780 , by the present Sessions House on Clerkenwell Green. A new house of correction, where the Fenian attempt took place, provided for the custody of misdemeanants, hard by.

I recollect very well hearing the Clerkenwell explosion. I was in my room at the Post-Office at the time, and the effect was as though a heavy piece of furniture had fallen down on the floor above.

Sir Baptist was a wealthy silk-mercer of Cheapside, $\mathrm{He}$ was knighted early in the seventeenth century, subsequently made a baronet, and finally a peer, under the title of Lord Hickes of Ilmington and Viscount Campden. He died in 1629, his widow erecting a monument to his memory in Campden Church, in Gloucestershire.

Hicks's Hall survived in name long after it had ceased to exist as a building. It stood, as the record in St. John Street shows to this day, one mile one 
furlong and thirteen yards from the Standard in Cornhill, and four furlongs and two hundred and five yards from Holborn Bars.

The latter were formerly to be found across Holborn, east of the top of Gray's Inn Lane and Middle Row. If I may trust to Bayly's map of 1765 for one fact and my own recollection for another, the Bars must have crossed the road exactly in front of a barber's shop-Gillingwater's, I think-outside which, in the late forties or early fifties, I surely saw one of the last of a series of remarkable placards. When bear's grease was supposed to be the finest possible restorative for hair growing thin, hairdressers or perfumers would occasionally electrify London by announcing in the largest possible type, 'Another 'Tremendous Bear just Slaughtered!' Thus too did the barber, no doubt to amuse the public eye.

Before Holborn was paved, the roadway in wet weather was knee-deep in mud, and one of the earliest road-tolls levied in England was for its repair. It does not seem improbable that the Bars were erected partly for the purpose of enforcing and collecting the toll from travellers to the City, and partly for marking the City boundary, as in the case of Temple Bar.

So, along the highroads, carefully measured from one or other of the seven points, bowled such of her Majesty's British mail-coaches as I propose to touch on-to Hull; to Yarmouth; to towns on the Dover road; to the New Forest; to the West of England and Cornwall; through South Wales; to Liverpool 
and Manchester; to Carlisle, and to the Far North. On other highroads, the best in the world, I shall follow the track of the Royal mail-coach in Ireland.

While direct attacks of freebooters on the coaches, or the furtive theft of bags, might be frustrated by incessant vigilance, a sufficient armament, and an effective constabulary patrol, there was one formidable difficulty which no foresight could evade, no lapse of time eliminate, and that was the snowfall which, in any winter, might stop up the mail-roads altogether. 


\section{[44]}

CHAPTER IV.

SNOW.

Personally I have no recollection of being stopped, or even hindered, in my movements about the country at any time by snow, except perhaps on one occasion.

I was staying at Matlock, and having in the forenoon cleared off my official correspondence, I decided on employing the afternoon in riding across the lower range of the Peak of Derbyshire, and surveying the telegraph arrangements of Wirksworth and Ambergate. It began to snow heavily as I started from Matlock, and when I had ridden as far as Wirksworth further progress was attended with risk; indeed, I saw that even to get back in due course to Matlock Bath, the sooner I turned my steed's head round the better for both. The Peak is not a pleasant place in which to be snowbound; so I gave up the visit to Ambergate, and swiftly sought and regained the warm shelter of the Bath Hotel.

But the experience of the department in every winter has been that of struggles on road or rail, more or less arduous, with snow. 
With the record fresh of what mail-coaches had endured in winter time, it was an anxious question, in the very early days of railways, how the trains would fare in snow of a depth sufficient to hinder or stop a road coach. That question was soon set at rest. On December 20, 1836, in the deep cutting through the Cowran hills, on the Newcastle and Carlisle railway (along which the mails had just begun to be sent), the snow had accumulated to the depth of four or five feet, and a crowd of country people assembled to see what would happen to the train. Down came the Hercules steam-engine; it dashed right into the drift, cutting its way through with perfect ease and flinging snow chimney high, as the foam of a stormy sea.

On the occasion of the same storm, the snow lay on parts of the Dover road in drifts from eighteen to thirty feet deep. The French mails were sent by steamers from the Thames, and by the same vessels inland mails were landed at Gravesend and Ramsgate. Between Canterbury and Dover the mails were conveyed by stages. The road was not reopened until the new year had turned.

On Sunday, December 25, all the mail-coaches due reached London. On Monday, the 26th, only sixteen out of twenty-four arrived at all (twenty-seven were despatched nightly, but on the return journey twentyfour coaches were due as night mails and three as day mails). On Tuesday only two came in before noon,

$$
\text { * 'Encyclopædia Britannica,' } 1842 .
$$


and only five later on, so that seven night mailcoaches, instead of twenty-four, drove up to the PostOffice. On Wednesday an improvement was noticeable: fifteen coaches arrived in the course of the day. On Thursday, twenty, and on Friday, the 30th, all, except the Dover mail, reached London.

When the facts of Boxing Day were known, the Surveyor of Mail-Coaches, although ill and in bed, was equal to the occasion. On Tuesday, the 27 th, he arose, brushed his doctor aside and came down to the office. Calling the London mail contractors together, he laid his plans, and with eleven coaches, instead of twenty-seven, despatched Tnesday's night mail; grouping the bags on selected vehicles in order, as he graphically expressed it, 'to rake the kingdom.'

One coach to Salisbury took all three loads for the Exeter roads; a Bristol coach cleared off the West of England mail. The Norwich coach, viâ Newmarket, swept most of the eastern counties; lateral expresses branched off here and there, and filled in the gaps. The Holyhead and the Manchester coaches provided for half the Midlands, the great towns redistributing the mails, where the roads were open, right and left.

The Edinburgh coach, drawn by six horses, conveyed all the Scotch bags--the Glasgow mail as well as its own-and masses of bags for the Eastern Midlands. So heavy was the combined mail, so important, so difficult to redistribute with accuracy, that the Surveyor sent down with the coach one of the most dependable of his officers to see it safely through. 
This was Mr. J. H. Newman, some time Surveyor of the South-eastern Postal District of England, and now residing at Dorking, in Surrey. Mr. Newman recollects that, due to the roads being heavy and obstructed with snow, he did not reach York until Friday, the 30th, instead of Wednesday, December 28.

Again the mail-guards repeated the story of devotion to duty. Webb, who left St. Martin's-leGrand at eight p.m. on Tuesday, February 2, did not reach Bath until four p.m. the next day; he turned back with the up-mail the same night, and arrived at the Post-Office only at noon on Thursday - that is to say, after forty hours' exposure to the weather, two nights being spent on the top of his coach.

The guard (Cox) of the up Bristol coach, of the night of February 2, brought his mails into St. Martin's-le-Grand at one p.m. on the $3 \mathrm{rd}$, five hours and fifty-seven minutes late. The marvel is that he brought them in at all. At Calne the coach had become blocked in a snow-drift. Cox procured a light cart, and started a post-boy on horseback as pilot in front. They struggled on until within two hundred yards of Beckhampton Inn and the Waggon and Horses (which latter was surely just what they stood in need of) on the Downs; there, within sight of the cheering lights of both, the post-boy and his horse fell headlong together into a drift, and the cart could be got no further.

Then the guard abandoned the vehicle, mounted 
a saddle-horse, and carried his bags to Marlborough, accomplishing twelve miles in six hours. At Marlborough post-horses were available. He tried a short cut through Savernake Forest (the same 'lawny thickets of Marlborough' which De Quincey speaks of), only to be baffled by the snow, and compelled to turn back to the highroad. Thereon he found several coaches buried wheel-deep, and blocking the way. Intent on his own mails, he contrived, by great exertions, to run the blockade and get to Hungerford. Here the Great Western Road became clearer, and, with spirit unabated, this valorous official set himself to make up lost time. In fifty-eight miles he regained an hour and ten minutes, and at last reached the General Post-Office. When he got there, he heard that all the mail-coaches due off the Western Road were missing.

Moore, guard of the Worcester mail, was overturned during the night in a snow-drift, but by great strength and activity he righted the coach, and, impounding carthorses, brought it forward to Enstone. He must have been own cousin to the man-if not the man himself-(an Irishman, by the way) who, according to tradition, in the north yard of the General PostOffice, got underneath a mail-coach, arched his back, and, in the presence of the Postmaster-General of the day (who had wagered a dozen of port with a friend), lifted all four wheels clean off the ground. A mailcoach weighed not far short of a ton.

Mr. C. Boniface, of Summerhill, Dublin, is another 
of the old race. He was a mail-guard for exactly fifty-one years-beginning with Irish mail-coaches in June, 1836 ; travelling over all parts of Ireland; suffering from exposure on roads blocked with snowdrifts; and winding up his long and arduous service in June, 1885.

Upset four times, and having, as he tells me, adventures too numerous to mention, this fine old survivor of the past recalls especially two violent storms-of snow in 1838, and of wind in 1839-which respectively filled up the highroads with snow and fallen trees, and for a time stopped all traffic.

'Peter's in an awfu' feery-farry the nicht, neebers ; ye wud think he was a mail-gaird,' says Ian Maclaren, by the mouth of Drumsheugh. Thus, amongst other ways, have the activity and devotion of the old racenow alone represented by a solitary survivor or soof the mail-coaching days left marks both on history and fiction.

No doubt it was customary for guards and others to give an inkling, when they could, at the post-office of the presence of a Surveyor or other superior official on the mail-coach. In Swansea it is a tradition that a particular guard would, on such occasions, on passing along the Strand, wind a special mot, as Wamba did, on his horn, so that the knights of the sorting-table within the post-office might have warning that the foe was upon them before the mailcoach reached the office door.

The achievements of guards Cox and Moore are 
perhaps examples of endurance and resource. In other ways, not, howerer, connected with the mailservice, some curious instances of presence of mind and the reverse have come within my experience. Amongst them, I recollect, when the town-hall of Leeds was in course of construction, in the fifties, seeing a workman cling to the chain of a windlass fixed in the scaffolding of the tower, and resting his feet on a knob or hook at the extremity, allow himself to be hauled up, dangling in mid-air, to a height of probably sixty or eighty feet. Similarly, in the construction of the new General Post-Office (North), it was a common practice for labourers to be lifted twenty or thirty feet in the air, holding on to a chain, and then to be swung by a partial revolution of the foot-plate of the steam-crane from the southern side to the eastern front. In either case, a momentary dizziness would have meant destruction.

On the other hand, while I was travelling by rail to a Midland town, and my train was passing through a cutting, the reservoir of a cotton-mill, filled to overflowing by heavy rain, burst and swept down bales of cotton on to the line, throwing the train off the rails and bringing it to a standstill. No one was hurt. But because the line was flooded, we, the passengers, had to pass along by the foot-boards of the carriages, clamber on to the engine, and slip down easily enough from the front of it to terra firma. Perhaps the upward gradient left the ground dry there, or possibly the platelayers had made a rough 
pathway of old sleepers, but in any case there was neither difficulty nor danger in getting down and across the line to shelter, dry-shod. One passenger, however, a man in the prime of middle life, was paralyzed with terror. He could get as far as the tender, but no further. At last the guard and fireman made him shut his eyes while they carefully lifted him down and carried him to a house hard by.

Again, a friend of mine told me that he and two other gentlemen, having procured leave to do so, once paid a visit of inspection to the Menai Tubular Bridge, all three walking on the broad top of one of the tubes. When midway between Carnarvonshire and Anglesea, the self-possession of one of the three friends failed. He dared go neither forward nor backward. In the upshot he had to lie down on his back, and each companion taking a leg, they actually drew him in that position back to the starting-point.

The Waggon and Horses at Beckhampton has been, I am told, in the hands of the same family for several generations, and has enjoyed, as a roadside inn should, a great reputation for excellent home-brewed beer. Wayfarers had need, in the thirties, to be strengthened by a generous stimulant, in facing the breezes of the wide-spreading downs, and well armed, in preparing for the possible attentions of highwaymen. For not only was there, early in the century, a gibbet west of Beckhampton-memorial of a mail-coach or other highway robbery-but two and a half miles on the 
London side of the pleasant town of Calne was to be met with the anything but pleasant Cherhill ganga goodly company of footpads who, in mail-coach days, stuck at nothing.

A former Vicar of Cherhill tells* of the defence, at the assizes, of an alleged highwayman (possibly one of the Cherhill men) by the late Mr. Henry Nerewether, who was so successful in his address that his client was acquitted, and left the court with a character altogether spotless. The same night, on the way home, Mr. Nerewether was stopped on the downs; timely help arrived, the freebooter was arrested, and found to be the lawyer's client of the morning.

But although the Waggon and Horses at Beckhampton was a familiar sight to travellers by the Bath road, the true Beckhampton Inn-twenty-six miles from Bath, where, I take it, passengers by the down night mails snatched, soon after five a.m., a very early breakfast, as an earnest of better things at Bath or Bristol-still stands, but it is in private occupation.

Less than a mile west of the famous barrow or mound-one hundred and seventy feet high, and in diameter five hundred feet at the base, and more than a hundred at the top-known as Silbury Hill, will be found, at the junction of the Calne and Devizes roads, a substantial square-built house of two stories and fourteen front windows. It has its principal face towards the former road. With a central porch,

* 'Cherhill Gleanings,' Rev. W. C. Plenderleath, M.A. 
and thickly covered with the foliage of creepers, it is the beau-ideal of a first-class posting-inn in the best of the coaching days. Large training stables are attached to it, and young race-horses occupy looseboxes where formerly pairs of post-horses found a home. This was once Beckhampton Inn.

In 'Forty Years at the Post-Office' I have recounted the adventures of mail-guard Nobbs, in carrying the mails to Aberystwith, in the late thirties. I will now add that, properly to appreciate the difficulties of that journey, it is needful to bear in mind that the distance from Cheltenham to Aberystwith is $116 \frac{1}{2}$ miles; that the young man rode in a mountainous region (Padnor Forest is 2,163 feet, and the top of Plinlimmon 2,463 feet, above sea-level), in the depth of a severe winter; and that the concluding part of the journey had to be traversed, partly by post-chaise, partly by cars, and partly on foot.

The winter of 1836-7 must have recalled, to anyone then alive to remember it, the great snowstorm of January, 1776, when, according to Gilbert White, the company at Bath, who wanted to attend the Queen's Birthday Drawing-room, were strangely incommoded. Many carriages which had struggled as far as Marlborough were there stopped altogether. 'The ladies fretted, and offered large rewards to labourers if they would shovel them a track to London. But the relentless heaps of snow were too bulky to be removed.' 
In 1854-5, just before I became a postal servant, the winter was remarkable for the duration of frosty weather, but I have no note of the extent to which it affected the mails. I was more concerned in those days with telegraphs, and the frostier the weather, the better we got on, until the wires snapped and struck work altogether.

In February, 1855, there were seventeen days in which the mean temperature was below thirty-two degrees. The like had not since been known until 1895, when from January 25 to February 18 there were twenty-five such days. Darwin seems to have been impressed by the cold of the earlier period. 'I estimated,' he wrote, 'that the winter of $1854-5$ destroyed four-fifths of the birds in my own grounds. *

But the posts ran in 1854-5, to the best of my knowledge, with reasonable punctuality. History, as far as the weather went, did but repeat itself. 'December 24, 1785, to January 7, 1786,' records Gilbert White, ' ' hard frost; 14 th to 21 st, deep snow; February 22 to March 10, hard frost. On May 1 and 2, thick ice.' He says, however, nothing about the Selborne postman, nor, indeed, of mail-riders, who somehow had to struggle through the snow.

It was in London on January 22, 1881, as White had found it on January 22, 1776. 'But the Netropolis itself exhibited a still more singular appearance than the country; for, being bedded deep in snow,

$$
\text { * 'Origin of Species,' John Murray, } 1860 .
$$


the pavement could not be touched by the wheels or the horses' feet, so that the carriages ran about without the least noise.' I was at a Surveyors' meeting at Malvern, and did but hear rumours of serious stoppages of the mails. Had there been mail-coaches on the road, they must have given in altogether. Tewkesbury, I recollect, was blocked with snow, except where, in the town, a roadway had been cut.

The winter of 1894-5 compares in duration and severity-if not in amount of snow-fall, at least in respect of frost-with many of the trying winters already referred to. Even snow made itself felt in no small degree. The beginning of February found the whole of Great Britain wrapt in a white shroud. The appearance of the land recalled the January of 1881 I have just referred to. The North of Scotland, however, from a postal point of view, was the chief sufferer.

Sutherland and Caithness were practically sealed up. Near Wick, the mail-train, on the way to Georgemas, became embedded in a snow-drift twenty feet deep and half a mile long. The snow on Blair Atholl Station platform was up to the knee; in the cuttings it was over a man's head. Three engines braced together, with a steam-plough in front and a carriage full of workmen behind, prepared to charge a block in Struan cutting. But the attempt was relinquished as hopeless.

As in 1887 , so in 1895 , the Dava cutting filled up 
with snow; and a train, which was sent to the relief of other blocked trains, strove to penetrate the obstruction, with the only result that its snow-plough, two engines, and the intrepid superintendent and assistant-engineer of the Highland line, crashed into wreaths of snow twelve to fifteen feet high, and there remained until a rescue-party arrived. Where it was possible, the local mails were put on board steamers, and forwarded to the Northern ports by sea. One block in Caithness continued for eight days.

On the Skye line, the mail-train, after cutting through heavy drifts, encountered a twelve-foot wreath at Auchterneed, ran into it, and stuck fast.

The department had a very trying time in the South of Scotland, the fall of snow being greater than anyone living can recollect in that quarter. The lines between Carlisle and Ayr and Glasgow were liept open; but the Stranraer line, which branches from the Carlisle-Ayr line at Dumfries, and runs for about seventy miles through a highly picturesque, but in parts rather wild, country, as well as the Portpatrick and Wigtownshire and Whithorn lines, were all hopelessly blocked. The mail-train, with a sorting carriage attached, was snow-bound at Creetown for two days and a night before it was released, and the Post-Office sorters suffered a good deal.

The Larne steamer, on her way back from Ireland, at the commencement of the storm had to anchor at the mouth of Loch Riyan for a long time; and after- 
wards, having made a fresh start, the captain had to anchor again further up the loch. Next day he reached Stranraer. All the bags and baskets which had accumulated at Dumfries had to be sent by train to Ayr (Stranraer being inaccessible by land), whence they were taken to Stranraer by sea at night. For this purpose the Princess Victoria, or the Princess May (I am not now sure which), was brought round to Ayr.

The beautiful vessel was a wonderful sight when bearing up for Ayr Harbour. It was a day of bright sunshine, with a blue sea, like the Bay of Naples. The rigging, bridge, and all exposed parts of the vessel were covered with snow and icicles. The perils of the night were over, but Captain Campbell is reported to have said that he never could have imagined such blinding drift and intense cold as he and his men had to endure until they got fairly into the loch.

The country roads were of course wholly impassable for man or horse. But people in remote places nevertheless cried out loudly because they did not receive their Scotsman newspaper by post as usual.

In Ireland, even in the South, the drifts on Sunday, February 10, about Fermoy, were eight to ten feet deep. The mail-trains from Cork for Dublin could get no farther than Buttevant. Between that station and Dublin there are said to have been fifteen miles of impassable snow.

Great were the sufferings of the sorting-officers in 
the travelling post-office of the American mail-train for Cork. They had nine hundred and twelve bags in their charge, and were more than a day late in arriving at Queenstown. They left Dublin about daylight on Sunday, and before mid-day they were blocked in the snow, remaining stationary for five hours below Kilmallock, and for three hours below Charleville. They were twenty-seven hours and ten minutes in the sorting-vans, a blizzard blowing outside and the temperature being below zero within. The Cunard steamer was detained for a whole day.

In England, there were scarcely ferrer opportunities of devotion to duty. On the highroads, thanks to the efforts of the local authorities, ploughs and shovelling gangs were brought to bear; but in the Pickering, Darlington, and Hexham districts, the quantity of snow which fell offered great obstruction, and caused serious interference with the postal service.

About Pickering, the fall of snow was the heaviest known for forty or fifty years, the drifts in some places rising to the height of twelve feet. On January 1, 1895, the mail-cart service between Pickering and Rosedale Abbey (ten miles north of Pickering, in the heart of the Cleveland Hills) the road to which is almost entirely across open moors, was wholly suspended. It was only restored the next day after prolonged efforts. The mail-cart (which could be got fortrard by stages of but ten yards at a time) had 
to be left on the highroad, the mails being taken on horseback across the fields.

The services in the districts of Middleton-inTeesdale, near Darlington, and Haltwhistle, near Hexham, were carried on with much trouble, as was also the case near Thirsk, Malton, Northallerton, Bedale, and Durham; but the greatest difficulty of all was in the Pickering and Rosedale Abbey service, as already described.

'The marked feature of this Arctic winter' [referring, no doubt, to the snow], says a correspondent writing on February 28, 'has not spared Shropshire and North Wales. In Carnarvonshire the roads have been blocked. Our first heavy fall was on Saturday, January 12. The mail-cart from Newport to Shifnal was also stopped, and on that Sunday the cart from Congleton (Cheshire) failed to get through a drift on the road to Chelford. The drivers from Carnarvon to Llanberis and Beddgelert both had to leave the mail-carts, and slinging the bags on their horses' backs, make the best of their way on foot, returning with the inward mails in the same fashion.

'Both last month and this the line between Bala and Blainau Festiniog has been blocked for several days, and the outward mails had to be diverted viâ Llandudno Junction.'

A letter from Laxey, in the Isle of Man, dated February 14, said, "The trams have all stopped rumning; as in some places they pass through, the snow is eighteen feet deep. I was speaking to a man 
yesterday, who has lived here, in Laxey, sixty years, and he never remembers such an awful blizzard.

- We had no post from last Monday until Saturday, and then the postman brought the letters in saddlebags slung over the horse's back. Last night he had to walk, carrying the sacks himself, eight miles from the steamer. I think, if it lasts much longer, you will not have many more letters from me.'

The great feature of the winter, however, was the duration, rather than the severity, of the frost. One careful observer records that it commenced on December 27, 1894, and ended only on March 6, 1895 -a period of seventy days. During this period, with two exceptions, the minimum temperature on the ground was below thirty-two degrees. There were days when the intensity of the cold was very great; five degrees below zero in Leicestershire, eight degrees in Kent, and even seventeen degrees in the hill country of Aberdeenshire, are examples.

Happily for the postmen, intense frost-trying though it was-meant dry walking in country roads and along rural lanes and footpaths. For of rain there was naturally next to none. The month of February, 1895, was nearly as dry as the absolutely rainless February of 1891. Not more than an eighth of an inch of rain fell. Even if snow-bills were plentiful, the Post-Office was put to no expense for special boating and ferriage in the rural parts. 


\section{[6I ]}

\section{CHAPTER V.}

ACROSS THE HUIBER.

I A a a fraid it is less the size and importance of the chief port on the Humber-its population, activiiy and wealth-which causes the memory to retain a lively impression of my arrival within its precincts for the first time, than the fact that I had just settled up one of the heaviest hotel bills it had ever been my lot to experience. My arrival on the Humber, therefore, was rather in the nature of a strategic movement in the face of the enemy, than a voluntary sojourn within sight of its broad and swift-running stream.

For with several colleagues I had been engaged in the North of England, in the early seventies, in surveying and concerting telegraph arrangements. We had fixed on Scarborough as a convenient as well as pleasant centre from which we might arrange divergences to some of the neighbouring towns within our programme of visits - out in the morning, as it were, and back again at night-and rooms, certainly very fine, spacious, handsome rooms, had been 
secured for us at a leading hotel. But when the first bill in due course came in for our entertainment, we found that the apartments might well be deemed sufficient in their appointments, inasmuch as we had inadvertently occupied an ambassadorial suite.

Now, the travelling allowances of officials of our degree were not quite equal to those out of which an ambassador presumably would defray his costs. So we discovered that urgent business at once called us to a distance, and we left Scarborough, and moved southwards, with pleasant recollections but depleted purses. Thus I arrived somewhat earlier than projected on the northern bank of the Humber.

It is well known that Kingston in Kent, Kingstonon-Thames, Kingston in Canada, Kingston, Jamaica, and perhaps many other Kingstons, flourish; but the greatest of them all is certainly the north-eastern seaport of Kingston-upon-Hull.

The true name of the great post-town next the Humber is, however, in a fair way of being forgotten; and the little river, which rises at Driffield, twentyeight miles away, on which the town stands, and from which it derives its modern title, is probably far more widely known than even the broad estuary which receives the Hull's inland waters.

With the gradual change of name from Kingston to Hull there has been a more rapid obliteration of the former landmarks. There is no citadel now. It was last used for military purposes in 1848, and its final remnant-the south block-house-was pulled down in 
1863. Sword and gun have been wholly superseded by the pen-the fosse by the wet-dock. Commerce, fostered by the mail-coach, and stimulated by cheap postage, has swept away the fortifications.

The old town remains virtually an island. The Hull, seventy yards wide, on the east side, the Humber on its southern front, and a succession of docks on the western side, admit of complete circumnavigation, should a modern explorer essay the task.

With more than adult vigour the new town has, in one direction, overleapt this watery barrier, and now extends fully a couple of miles beyond it.

In Hull, in 1808, the elder Nathews gave his first entertainment, under the title of "The Mail-Coach Adventures.' These must have been plentiful for the subject to be popular, and sometimes humorous, as well as exciting, inasmuch as a feature of the programme was a favourite comic song styled 'The Mail-Coach.'

To the port of Hull belongs the distinction of providing the merchantman to which the worst of Australian bushrangers-always excepting the leader of the Kelly gang-one Michael Howe, was apprenticed. Howe was not, however, born in Hull. He broke his indentures, entered and deserted from a King's ship, was tried at York for highway robbery, and was finally transported, in 1812 , to the penal settlement in Van Diemen's Land. There, being assigned as a servant, he again absconded, joined twenty-eight other desperadoes, and for six years ranged the colony far and wide, making his name notorious by robbery 
and murder, after the manner of a bush ranger wholly given up to crime. Twice in custody, he twice escaped from justice, until at length, like the Kellys, he was shot down in an attack on his last hiding-place.

But we may brush aside the recollections of Howe, and recall the remarkable fact that the Right Hon. C. P. Villiers, who in July, 1895, was returned to Parliament as member for Wolverhampton (which he has continuously represented since 1835), was a candidate for the representation of Hull in 1826. The Right Hon. W. E. Gladstone, who has just retired from Parliament, was still a schoolboy at Eton at the time of Mr. Villiers' candidature.

In Mytongate was born, with the century, John Wheat,* who, when I penned the previous paragraph, was said to be one of the oldest printers in England. He was 'at case' before the battle of Waterloo, and could recall, not merely the inking-balls of early typography (which I recollect myself to have seen used with the old Stanhope press), but the days when the editor of a newspaper in Hull considered it quick work to publish London news only four days old. That was possible when the post went wholly by York, and, perchance, lagged between York and Hull.

In the first part of the century, the postal key of Hull, it is hardly too much to say, was the little town of Barton, near the southern bank of the Humber, opposite Hessle. Here the river is from two and a half to three miles wide, and the tide runs fast.

He died in Sheffield, September, 1895. 
Hence, those who would reach Hull by coach direct had to face the passage of the Humber, either (as in very early years) by sailing hoy, or, after 1816, by steamer to Hessle, on the northern bank, or direct to Hull itself. To be exact, it is five miles one furlong five chains to the eastward from Barton Pier to the centre of the entrance of the Humber dock.

The ferry at Barton-on-Humber had a real importance of its own, apart even from the Hull trade. It was in the line of direct road from London to Beverley Minster, Driffield, Scarborough, Whitby, and Flamborough Head; and Hull was reached that way in 174 miles from Hicks's Hall. But, because of the trying passage of the Humber, another route, through York, was made far greater use of, even though it increased the length of the journey to $236 \frac{1}{2}$ miles.

So the Waterside Inn at Barton became an important place much earlier than what are now understood as mail-coaching times, but while stage-coach passengers crossed by the Barton ferry, the Hull mails took the York route. They do so, almost, to this date, inasmuch as the night mail comes up to Milford Junction, not far from York, on its way to Normanton, by the North-Eastern Railway, and it is only the day and some other mails which avoid that great angle, and run round the easier corner formed by the crossing of the river Ouse at Selby by the Great Northern Railway.

A stage-coach ran from London through Lincoln 
to the Waterside at Barton, it is said, as early as 1723, but it was nearly eighty years later, i.e., not until April, 1801, that Hull for the first time received its London mail direct by this route.

The cathedral city, it is said, was put into communication with the Metropolis by mail-coach in 1786 . But Lincoln's only connection northward was by means of the stage-coach mentioned, and that vehicle, it is probable, carried no bags. Hull got its London letters from York off the London and Edinburgh mail. and little Barton-on-Humber procured its handful of correspondence by tapping the same source at Bawtry, near Doncaster. Letters between Barton and Hull went a long way round.

At last the Lincoln coach was extended to Barton and the Ferry. Sending its passengers to Hessle or Hull by the steamer, it stabled itself and its horses at the Waterside Inn, and did so until about 1837, when the service ceased. This hostelry is worth remembering. It was a substantial building, consisting of a central block and two wings, with spacious courtyard and oftices in rear. Only the north wing remains in occupation; the rest has long since been pulled down. Cattle, which used to crowd the ferry, pass by rail; such local mails as cross the water go, for the most part, by the steamer to New Holland, and Barton's place in the great machine of public locomotion seems to be no longer.

The post-office of Hull, like some other great postal centres, can recall the day, at the end of the eighteenth 
century, when its staff was very limited. In 1798 Dickey Sagg was its prized and only postman. $\mathrm{Mr}$. Sagg was a small man, and wore a swallow-tailed coat-a combination of facts which passed not unnoticed by the boys of the grammar-school. But Richard, though small, was himself again when delivery-time came round. He had the reputation of being the fastest walker in England; and he delivered the letters for the whole of Hull by his single hand, covering one half of the town in the morning, the other in the afternoon.

Mr. Sagg was autocratic in his methods. He would take his stand in a square or court, and call out the names on the letters for people residing there. The inhabitants then came out for their letters. If they kept Sagg waiting, his language was more vigorous than polished; and he would rebuke the slothful by taking the letters to his home, for them to fetch at their pleasure. It would be a deeply interesting experience to see how Mr. Sagg's successor would now, a hundred year's later, be received by the public at $\mathrm{Hull}$ if he acted thus.

I am glad that I know where the dust of this doughty Yorkshireman rests. His gravestone stands, or once did, in Holy Trinity churchyard, against the wall on the south side, near the west door. I have ascended the belfry of Trinity Church: would that I had paused at the foot to take a copy of the inscription to the memory of the fastest postman on record. 
It passes comprehension what could have come to Mr. Rodmell-the first postmaster appointed to Hull in the nineteenth century - to select as a successor to Sagg, who did the work of two postmen, a one-legged man, John Stones, to struggle with it alone. Yet there was nothing to complain of in the way in which Stones comported himself, except, perhaps, that he had a genial preference (as I should have) for persons who called for their letters at his house in Dagger Lane, rather than for those who put him to the inconvenience of delivering the letters as addressed. To facilitate business, he considerately wrote up over his door the legend, 'The Postman lives here'; so that really it could never be alleged with truth that the postman was not to be found. All the same, Mr. Stones distributed the letters vigorously throughout the town; and the stumping of his wooden leg was a familiar sound in the streets.

There was another postman of mark, who, like a sensible Yorkshireman, took life as easily as possibleJoseph Jarvis. He was in the habit of starting out with the letters, then going home to breakfast at eight o'clock, and beginning again at ten. Neighbours expecting letters would call at his house to get them, a proceeding which saved time, was quite simple and easy, and had, as in Stones' case, and from the postman's point of view, much to recommend it. Jarvis was wise in his generation. He ensured leisure and to spare for courting and marrying Elizabeth, daughter of Ralph Darling, Mayor 
of Hull. After marrying the Mayor's daughter, he left the Post-Office, as might be expected, and took, I am bound to add, a public-house in Ryton Gate, called the Phœnix Tavern, which was rather a come-down after the Mayor's House. He died August 24, 1828, aged sixty-five.

Jarvis would have done better if he had eschewed the tavern and taken a leaf out of the book of the Coal-heaver, who, about his time in the present century, came from heaving coals at Thames Ditton for ten shillings a week to be the Rev. William Huntington, of Providence Chapel, Gray's Inn Lane. By virtue of his preaching, he married the titled widow of a lord mayor, and rode in his own carriage, instead of taking to a public-house or throwing coals out of a barge.

One young postman, named Mosey, had also an eventful career. A smart and active youth, he was taken into the office by Mr. Rodmell in 1810, and, thanks to natural gifts, had by 1841 risen to be postmaster. He held office down to my time-in fact, until 1864. I have known several most efficient officers of control who, like Mr. Mosey, rose in this way from the ranks, first being employed as postmen or telegraph messengers.

The post-office at Hull has had its flittings from a little room, which still exists up a court (though its delivery-window is papered over and lost to view), to a fine building, which worthily houses it, in the Market Place. 
In 1689, the court or passage I speak of lay between Grimsby Lane and Blackfriargate. This location is attested by the fact that, in the passage, lived Dr. Lilley, and the postmaster of the day ' gotte amaine to ken hyn throgh comyn toe Deposite lettres yn ye Box.'

The department has ever had a secret hankering after offices up long passages. Perhaps at the end of a narrow entry office room was cheap, or a passage gave an idea of shelter from the weather. Not alone in London, or in Hull, but in scores of places, Post-Office Court, marked the site of the establishment.

In Dartmouth, I recollect the old post-office was in a garden; at Canterbury, in Leeds, and in many other towns, the perplexed client had frequently to find his way up a court or side-passage.

So, after Grimsby Lane was vacated, came another site of the same kind, for, in 1792, the post-office was situated in a long narrow passage called Post-Office Entry, leading out of Bishop Lane. The postmaster was then John Wray, who held the office until liodmell's appointment in 1805. Of the building in Bishop Lane, it was said in a local history, "The exterior of this place is entitled to no particular notice,' which was rather an uncivil remark.

The narrow passage leading up to the Bishop Lane office was perfect in its way. At a certain state of the tide it was flooded with water, and boys earned a modest competency by exercising the honourable 
function of carrying a letter through the wave to the letter-box for a penny. Here was a penny postage regardless of weight, which eclipsed Sir Rowland's best performance!

But this was not all. A very stout man frequented the passage, and Mr. Mosey used to tell, with glee, how when he opened his mouth-that is, stuck his arms akimbo-other dogs who had letters to post might bark in vain; for no one then, to the full enjoyment of the stout man, could, except at his pleasure, pass either to the post-office or from it.

This picturesque arrangement of office met the wants of the good people of Hull for forty year's. In 1831 , a move was made to a house, now in $\mathrm{Mr}$. Jesseyman's occupation, in the Land of Green Ginger. Here was rented a single room, about fifteen feet square, in which the postmaster and his two assistants did the whole postal work.

As for the six postmen (Hull had grown larger by that time, and received more letters) who needed a quiet corner for arranging the inward correspondence, was there not the usual fine airy passage outside at their disposal? What greater facility could be desired? The public especially had plenty of space, inasmuch as they stood in the street and dealt with the postmaster through a hinged flap in the window, as was the general custom. Thus at Hull the office advanced with the times.

But as the age progressed, wealth and luxury increased, and even Yorkshiremen grew in a sense 
fastidious. They declined to stand in the street and be rained upon, or blown about, whilst registering letters or buying stamps; and having had enough, a couple of hundred years before, of Blackfriargate, they now constrained the department to remove itself, in 1843 , to Whitefriargate, to premises erected by the Brethren of the Trinity House. Even here the public were not long content, for by 1847 they insisted on an enlargement, thus critical had taste become in this serious matter of an adequate post-office.

But with penny postage, savings bank, postal orders, and telegraphs, even the Trinity House Chambers extended did but suffice for a bare thirty years; so in due course came the grand, and perhaps final, move to the Market Place.

No more blocking up of gangways by fat men; of sorting up an open passage; of standing out in the rain to argue with the postmaster. The Government (egged on, I do not doubt, by Mr. Norwood, M.P., who then sat for Hull, and was a power in the land) built a brand new post-office, four stories high, giving, instead of an apartment fifteen feet square for all purposes, a sorting-room which alone is seventyeight feet long, and nearly half as wide, and which towers aloft, having a ceiling twenty feet above the foot-mark of its tenants.

Within my own personal experience the force of the Hull post-office has been enlarged from thirty-seven to three hundred and seventy-five persons. Its cost, like its persomnel, has increased tenfold. 
In 1839 , before penny postage came in, the weekly average of letters at Hull was two thousand five hundred; now it is more than three-quarters of a million. The York bag would sometimes contain a single letter; now it is full of letters. By the night mail, a hundred and fifty bags and parcel baskets are sent off-a mountain of matter, which needs two or three vehicles for its conveyance to the railwaystation. Mr. Duesbury has no sinecure.

O memories of Dickey Sagg, of Johnny Stones, and the leisurely, mayor's-daughter-marrying Jarvis! how would any one of you now compass, singlehanded (and one of you single-legged), the delivery of letters for Hull in a day? How now, Billy Levitt, borough-bellman, would you contrive to carry the bags, brought by the down night mail, on your arm, as you did in the old coaching days, from the south end of the Humber pier to what residents in Hull as in every other large town in England are given to term the General Post-Office?

What would have been your astonishment, Postmasters of Hull in the eighteenth century, at there being a demand, not only for one post-office, but for thirty-one or more in the town, besides the head office on the island, facing the river-to say nothing of fifty-one sub-offices lying outside in the villages, which include those with the deeply interesting names of Wawne, Swine, Roos, Skirlaugh, Bewholme, and Thorngumbald? Though, by the way, Bilston, in Staffordshire, by far eclipses Hull in curious names, 
for in and around the former are Catch-em's-Corner, Gibbet Lane, Hangman's Row, Darkhouse Lane, Shift End, Throttle-goose Lane, and so on.

The service by mail-coach to the Humber virtually ceased when the bags were diverted from the road north of Lincoln to the railway and taken to New Holland; but from Lincoln, southwards, the mailcoach continued to run through Sleaford to Peterborough until September, 18t6, when it was taken of the road.

The Hull coaches are now, I think, almost wholly forgotten; and the ferries, except that to New Holland, are little more than a tradition; but trade and population increase without a check. Absorption of the extensive docks into the system of the NorthEastern Railway sounds the latest note of progress and points to a fresh lease of prosperity for this ancient seaport. 


\section{[ 75$]$}

\section{CHAPTER VI. \\ EAST AND SOUTH-EAST.}

Atrentive reader's of the works of Charles Dickens will be aware that, when David Copperfield went the second time to visit Mr. Peggotty at Yarmouth, he travelled by the mail, on the night of a storm, which grew worse as he passed through Ipswich, seventy miles from London, at, I assume, twelve minutes past three o'clock in the morning.

I, too, went down to Ipswich not long afterwardsthat is, while the so-called railway mania was still a living force-and had two novel experiences: the vision (as I believed it to be at the time) of an actual ghost, and an introduction to the level, the theodolite, and the art of surveying for a railway, which I have not yet forgotten.

In 1846 speculation ran ligh. The spirit of gambling broke out in epidemic form; enterprises of all kinds were set on foot, but the construction of railways - on paper-chiefly caught the public mind, and turned the public head.

Everyone with a coat to his back, and some know- 
ledge of the three R's, could reckon on receiving a guinea a day and expenses for his valuable services in connection with projected lines, whether as traffic inquiry agent, or eren amateur engineer; the trained land surveyor could command his own price, and the untrained youth could soon pick up a smattering (as I did) of field-work, which enabled him to run a base line, take angles-even levels-keep a field-book, and plot a section, with the best.

An elder brother (who had properly graduated in the profession, and whom I accompanied to Suffolk) had, some months earlier, planned, as the result of a few weeks' work, a line from Barnet to Tottenham, a distance of six or eight miles. He took his map to the Eastern Counties Railway Company, who gave him five hundred pounds for it-so easily was money made at that period-and then put it in a pigeonhole, where, unless Sir Cusack Roney afterwards tore it up, it is, perhaps, still.

My ghostly visitor at the ancient inn we stayed at in Ipswich came through the wall, arrayed in purest white, quite in the orthodox way, at four o'clock on a summer's morning, wavered about the end of the bedroom for some moments, and then, gliding across it after the manner of ghosts, again passed easily through the wall. A few years ago I slept a second time in the same imn, and, as I fancy, in precisely the same room. If so, the mystery cleared itself up in the most matter-of-fact way.

In the wall opposite the foot of my bed was a fire- 
place; on its left, a small second door, which I had not noticed, and which had doubtless admitted the ghost; and to the right hand, a clothes-press, in which the diaphanous drapery suitable to such a visitant no doubt was kept.

In the early morning, and not aware of the room being occupied, one of the family must have come in, clothed in 'white samite' (or a clean nightgown), 'mystic, wonderful,' for his or her habiliments.

Passing from imagination to substantial realityfrom the baseless fabric of a dream to actual factI would mention that not far off the Ipswich road, in a village postally subordinate to Colchester, the subpostmistress is eighty years of age. On visiting her office one morning at half-past six, the postmaster found her sitting at needlework. He tells me, also, that on calling one evening with the rural postman on his return journey, it was too dark to see inside the office, so the old lady, without any hesitation, stepped outside, and, kneeling down at the doorsill, timed and signed the postman's bill. This seems to speak well for the healthful tendencies of employment in a small country post-office. I should like to clinch the argument by adding that with this old lady there had lodged for forty years a still older one, who died quite recently at the age of a hundred and two. But, unluckily for my contention, I cannot find that the latter took any part in postal work.

My brother and I were engaged on the preliminary survey for the railway from Ipswich to Lowestoft. 
Trains of fish-carts, I remember, carrying bloaters to the London market, creaked along the road at night. This was part of the traffic on which the new railway would have to depend. Coaches still blew their horns in spite of the coming line.

We comported ourselves as though the county of Suffolk was our private farm. For we secured as assistants two stalwart young poachers, who enjoyed themselves amazingly, especially along the hedgerows and in the copses, and, being native to the soil, apparently knew quite well a cock-pheasant from a wisp of hay, and a hare in her form from a fencestake. With them we surveyed where we listed.

A fine growing plantation near Campsey Ash stood in the way of the base-line; our two poachers went in with sharpened bills and made short work of it. Next morning, when Lord Rendlesham came on the ground, he found a bee-line cut through his young spruces, wide enough for two men to walk abreast; but I suppose country gentlemen were hardened by that time to such things, for his lordship, on the whole, took the matter kindly, and made no fuss. We were rather sorry to have cut eren a single twig of so courteous an owner's spinnies.

Some landowners were not so polite. Once while sketching and measuring the pleasure-grounds and out-buildings of a small estate, the owner, with a numerous following, peremptorily ordered us off his property. We submitted, and withdrew. Next morning by daybreak we were there again. and before the 
foe had got his shaving-water in front of him every measurement was made.

Then did the Parliamentary bar reap golden harvests, and contests before Lords and Commons suggest the legends, more or less well founded, of a railway company which spent a million sterling before it got its Bill; and of an eminent counsel whose 'retainers' were so numerous that his habit was to stroll in the Park while Select Committees were sitting at Westminster, so that he might not, by bestowing his talents on the brief of one client, give him a preference to the prejudice of others.

There was no opposition to the Ipswich extension line to Lowestoft, and the railway now runs over the lengths which my brother and I surveyed and staked out.

It was not so, howerer, in the district traversed by the Dover mail. There, as is well known, local opponents drove the trunk-line of the South-Easter'n Railway Company out of the true direction, forcing it to make an elbow at Redhill. Ultimately the company had to reduce the distance at great cost, by constructing a netr main-line from London, through Sevenoaks, to Tunbridge.

All unconscious, hotrever, of any approaching check to their prosperity, the coach and the postchaise rattled along the Dover road, as though it were, in truth, what the complacent Briton perhaps deemed it to be-a permanent highway of the nations.

It is an undeniable fact that (as Mr. F.'s aunt insisted) there are milestones on the Dover road, but 
it would have been not less to the purpose had the lady claimed that there were also turnpikes.

On the Great North Road, in the forties, we were fairly well supplied with turnpike-gates, but my impression is that in such respect no way out of London could compare with the first three or four stages of the Dover road. Gates were fixed at the Green Man, near the Surrey Canal; at New Cross; Deptford; Crooked Log, Welling; Stone Bridge, near Northfleet; at Chalk Street, south-east of Gravesend; and at Strood, two miles beyond Dickens's Gad's Hill and within hail of Rochester-seven gates in twenty-nine miles. Some, no doubt, cleared others, else a fourin-hand from London to Rochester must have cost in tolls alone a good round sum.

Probably no one who has driven over the first stage will forget the half-mile pull up Shooters' Hill to the crest of the road-not, indeed, over the highest point, but at considerably more than four hundred feet above sea-level. Perhaps it was from merciful consideration for mail-coach and post-horses that the old Bull Inn, where the first change took place, was planted half-way up the hill, 81 miles from London, so that it was a fresh team, and not the blown steeds from the White Horse in Fetter Lane, which had to tackle the remaining half of the ascent. The old house has been pulled down, and a new Bull Inn built on the same (north-eastern) side, very near the top, but it matters little to the Dover mail where the Bull is situated now. 
The department at one time maintained at Gravesend a shipper of mails. Many years ago, on the occasion of an official visit, I saw the old gentleman on the pier there. He explained, though not to me, the method of embarking ship-letter mails, as the outward-bound vessel came down stream at speed from one of the docks up the river.

'We ship them,' said he, 'as we used to harpoon a whale, having a long staff with a hook instead of a spear at one end, and a line at the other. Then, as the vessel comes down, we lie as near her course as we dare for safety, and harpoon her as she passes; that is, we catch hold of a rope, or port-hole, or what not, with the hook, and pay out the line steadily, until by degrees it tightens and our little boat is going as fast as the big vessel. Next we haul up close alongside; they throw us a rope, we tie it round the bags, they haul 'em up, and all's done, except the shouting.'

The reporting officer had to turn this account into strictly official language, and then thought he had rendered a most picturesque report.

From London Bridge to Dover, through Rochester and Canterbury, the distance is seventy-one milesi.e., by avoiding Chatham. Originally the London coach ran through Chatham town, along the High Street and up Chatham Hill, stopping by the way at the Mitre. But to save time was especially important, as, in view of the Continental mails and Government despatches, and the racing speed at 
which the Foreign Office couriers travelled, the shorter the road irs the better.

A by-road, called, as at Barnet, the New Road, was accordingly cut, which branched off from the Rochester High Street at Star Hill, ran at the back of Chatham High Street, and overlooking the town and the Medway, ended at Chatham Hill on the Dover road. Here a big mail-robbery once took place, to which I revert further on.**

Not much is altered in Canterbury since the Rothschilds' expresses flew through St. George's Gate, darting along the High Street, changing horses perhaps at the Fountain (where I have stopped, and which still lodges the visitor as well as it ever did), or perhaps at the mail-coach inn next the Guildhall - the Union, now a printing-office. Then, with fresh and fiery energy, they galloped through St. Peter's, and out on to the London road at St. Dunstan's, the Rothschilds' boys paying toll at Harbledown Turnpike, or plying the whip about Boughton Hill, while the rather sluggish mail-coach was trundling its wheels over the first bridge across the little Stour.

None overtook the Rothschilds' expresses. There is still living in Dover a post-boy, the last, or the very last but one, of those early days-Mr. William Gravenor. He rode the final express, in 1842, from

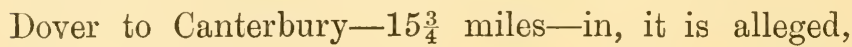
the very short period of thirty-three minutes. The * See p. 84 . 
horses were changed thrice before Gravenor handed over his charge at Canterbury to the late Harry Pincher, who took the despatches forward.

On that occasion, I am told, the whole journey from Dover to London (it is, as I have said, seventyone miles to the Surrey side of London Bridge) was performed in three hours and forty-seven minutes; equal to a mean speed, including stoppages, of $18_{\frac{3}{4}}^{3}$ miles an hour. This, although an extremely high rate, seems feasible with five-mile stages, but the swiftness of the run from Dover to Canterbury was certainly phenomenal.

The mean speed of the express, however, considerable as it was, does but recall what, according to Stow, Bernard Calvert did, either for a wager or his own pleasure, on July 17, 1619. He had provided beforehand relays of horses along the London and Dover road, and an eight-oared barge to await his arrival. Then, starting from St. George's Church in Southwark, at three o'clock in the morning, he rode on horseback to Dover, reaching that port at seven. He went into his barge, was rowed to Calais and back, again mounted his horse at Dover, soon after three o'clock in the afternoon, and reached St. George's Church, Southwark, in the evening at a little after eight o'clock, 'fresh and lusty.'

There is a curious restlessness about post-offices - the sites of them, I mean-which it is difficult to explain. Even in Canterbury, one of the last of 
places to favour the gad-about, the Postmaster-General has pitched his tent half a dozen times in fresh spots; in Canterbury Lane-but that was long ago; in St. George's Street, opposite the church dedicated to that saint; afterwards, six doors lower down; then, again, at the corner of Whitehouse Lane. Another bold shift planted it opposite Guildhall Street; finally - a nomad no longer-it halted on the site where I have known it for about twenty-five years, and where it now seems likely to remain.

The mails on the Dover road were no more exempt than other mails from attacks of freebooters. In August, 1814, poor Cephas Bates, with a foreign mail from Dover in his charge, on drawing near to Canterbury, was set upon, opposite the guide-post to Barfrestone and Eythorne, by two men, robbed, and violently beaten. One 'villain' had large whiskers, the other had none to speak of; one wore a short jacket, the other a long one. By these marks they were to be known.

Time wore on until, on the night of June 6, 1826, came the robbery near Chatham. Seven mail-bags and a box of letters mysteriously disappeared from the night mail between that town and Rainham. The empty receptacles were found next morning in a field near Chatham Hill. A reward of one hundred guineas stimulated search after the robbers. I think it was in connection with this latter case that a skilfully-planned alibi was set up, which brought off the adroit principal scot-free. 
Two thieves, as like each other as twins, dressed themselves in similar clothes, conspicuous in pattern and cut. One thief visited a number of West-Country towns, treated guests at the inns, complimented the barmaids, flattered the landlords. He paid his bills liberally and promptly as a man of spirit, and won the good opinion of all. Meantime, his confederate robbed the Dover mail.

When the actual robber was caught and brought to trial, plenty of honest people from the West-barmaids, commercial travellers, and landlords-came forward and swore an alibi. The poor gentleman languishing in the dock they would know amongst a thousand. Anxiety had paled his face, maybe, but those whiskers, the cut of that coat, the prisoner's height and bearing, they would swear to. $\mathrm{He}$ was no more guilty than the jurors, or my lord. 'Not guilty,' then said the jury promptly, without turning round in the box.

From the accident of Calais being opposite Dover, the mind-whether lay or official-insensibly turns from Dover as a large and important town, a fortress, and the chief of the Cinque Ports, to Dover as the goal of the first stage on the journey to the Continent and the eastern ends of the earth. If one launches on this view of the subject, the difficulty is where to begin, because a local historian of mark is inclined, with perfect justice, to date the earliest cross-Channel communication from an epoch before the Christian era. That opens a wide field of history. 
But as it is not clear that Julius Crsar had postal communication in hand-though there must have been such, or the reports sent home by him of the progress of the war in Britain would have fared ill-I am content to adopt the historian's latest view that the year 1782 saw the beginning of the regular packet-service across the Straits. That is a comfortable date, which synchronizes nearly with the establishment of mail-coaches and the Norwood postal dynasty at Dover, which lasted far down into my time. In the late fifties, Mr. William Norwood told me in the moonlight, about eleven o'clock one summer's night, as we were watching the embarkation of the overland mail, that the Dover post-office had been in his family for a hundred years, so that they had dealt with Calais mails under the second King George. There have, however, been many changes of postmasters in the last thirty years.

The Admiralty Pier and the cross-Channel service loom large in the duties of the Postmaster of Dover, but the chief official is a captain of the Royal Navy. There were regularly-appointed officers to take charge of the Indian mails through France-Mr. C. W. Wittenoom, whom I never saw, was one; and Messrs. John Payne and Thomas Fredericks, whom I knew very well, were others. At one time they saw the mails safely to Alexandria, afterwards only as far as Marseilles.

The latter told me of some early experiences in travelling through France, which were very trying. 
By a Postal Convention of April, 1843, the Government of King Louis Philippe bound itself to her Majesty's Government to convey the Indian mails over French territory-i.e., from Calais or Boulogne to Marseilles-in seventy-two hours.

The acceleration secured by this convention was a gain of as much as thirty hours on the previous time of transit under the convention of May 10, 1839, when the hundred and two hours which the French Post-Office were then allowed sometimes extended to one hundred and twenty-one. Bad roads, inundations, highways blocked, a sheet of ice twenty leagues long, near Paris; tired horses, at some stages none at all available-these and other casualties soon ate into time. Moreover, the old posting diligence was cumbrous in build, and incapable of attaining, even in favourable circumstances, the requisite speed.

Under the new convention, as a material advance, a very light fourgon was constructed, suitable for quick travelling. It had a coupé for the English and French couriers in front, and, while there was enough space for the mails, these unhappy gentlemen had to sit with cramped-up legs, whatever the temperature or time of year, for the greater part of three complete days. Mr. Fredericks remarked that once, on being lifted out of the fourgon at Lyons, or wherever it was that water conveyance commenced, he was quite unable to stand at all, and lost for a time the use of his legs altogether.

Mr. Payne, too, had anything but pleasing ex- 
periences. Of course, what his colleague suffered he in turn underwent; and as he was a much bigger, taller man than Fredericks, standing over six feet, and broad in proportion, his distress must have been greater still. Once he had an eventful trip. He lost forty-eight minutes in the run from Calais to Marseilles by a tragedy and a variety of other circumstances.

At St. Etienne, a child ran across the road, and unhappily was knocked down by the fourgon and killed on the spot. Further on the journey a not unusual incident stayed progress: the wheels were found to be insufficiently lubricated. Four times they caught fire, and had to be cooled and greased afresh. Linch-pins tumbled out and wheels came off. The fourgon came in collision with a cart, the postillion was flung from his saddle, was found to be seriously injured, and had to be left behind. At Neuilly, on going up a hill, eight horses being yoked to the fourgon, the leaders, though ridden by a fresh postillion, revolted and drew it down a bank. The two couriers jumped for their lives, got safely out, flung themselves on the horses, cut the harness, and righted the wrecked conveyance. This happened twice.

Such were some of the experiences incidental to posting the Indian mail across France.

In Dover, at the museum in Market Square, in the Plomley room, will be found the model of the King George passage-boat, which carried his Majesty's 
mails between Dover and Calais within the present century. The curious in such matters will be interested in learning that this old craft is a topsail cutter (long out of date), having a peculiar square sail, set like a flying kite, which could only be used in a light fair breeze. Having no lower yard to support the sheet, it became a balloon under pressure of air, so a strong breeze made it useless. Yet by its means, with a fair wind, King George's mails were carried across to France in three hours. What happened when the winds were adverse, as they sometimes were, I prefer not to say.

However, a shrewd conjecture may be formed. There has not been very much change, probably, in the wind and weather occasionally experienced in the English Channel since the days of King James I., when it is recorded that the Spanish Ambassador was held by 'cross winds in the Downs almost a sevennight before they would blow him over.'

It is certain that his Excellency lay in Deal three days waiting for a wind to embark; and his further detention was the subject of rather malicious rejoicing on the part of Sir John Finett, the King's master of the ceremonies, who had only received on parting an old gilt pot and a pair of gloves -in value together about thirteen pounds-a gift which Sir John declared was to the shame of both of them.

Foreign envoys, apparently, in the eyes of Court officials, were born to be fleeced and spoken of with contempt unless the vails were handsome. 
They knew what to look for at home :

' For as Lord Marmion crossed the court

$\mathrm{He}$ scattered angels round ...

* * * * * *

And he their courtesy to requite

Gave them a chain of twelve marks' weight

All as he lighted down.'

That was the example to which (in the opinion, apparently, of Sir John Finett) men of spirit with missions from abroad were bound to conform, regardless of the bearing of such a course on the official allowance for travelling expenses.

On the other hand, while sailing craft were the only packets available, the Vicar of Backwell and Curate of Maidstone electrified those parishes with the account of a journey to France in 1814, under the title (which must have puzzled some at least of his rural parishioners) of 'Mon Journal de Huit Jours.' What he really accomplished was the transit from Maidstone to Dover, Dover to Calais, Calais to Boulogne, and back again, and this he did so rapidly as to be scarcely more than a week away from his flocks. That the journey should be considered to have been performed with extraordinary swiftness is some indication of the state of the communication of that day; though it is proper to add that a writer, in commenting on the reverend gentleman's volume, expressed surprise, not that the author should have seen so much in so short a time, but that in 'huit jours' any man of common-sense 
and observation should have seen so little and fancied that he had anything to tell.

In the public mind, Robert Fulton, Patrick Miller, and Lord Stanhope are inseparably associated with the invention of the steamboat, at a date between 1787, when Miller published his book on the steamengine, and 1807, when Fulton's steamboat was placed on the Hudson. But the earliest inventor of all appears to have been Jonathan Hulls,* who, as far back as 1737, took out letters patent in London for a paddle-wheel steamer, and wrote a descriptive pamphlet. But it does not appear that Hulls was able to do more than demonstrate on paper the practicability of his scheme. It contemplated a condensing engine, which was to actuate a piston, by vacuum following on condensation, and not by expansion or direct pressure of steam. But whether the Symington engine, or another, was the first afloat, steam was in no hurry to visit the English Channel.

According to Mr. Paterson, 1820 saw the first steamer put on the Dover station. In 1837 the Admiralty took up the service which the Post-Office had for many years maintained, and ran steamers with the night mail, not only to Calais, but to Ostend. Then, as now, the French Government provided for the Calais day mail-service. Sometimes the passage was accomplished in two hours. When I first crossed, in the fifties, the steamship Queen took me over in about two hours and ten minutes. My recollection * Quarterly Review, vol. xix., 1818. 
is that we disembarked in the Roads, and landed by boat. The day of the Calais-Douvres was yet to come. Indeed, I do not think that the larger vessels have ever been put on the night mail-service.

Somewhere in the sixties-I cannot now remember the exact year-the contractors for the Dover and Calais mail-packet service made a great advance; they built a number of small but swift paddle-wheel steamers, the Breeze, Wace, Samphire, and Maid of Kent, of from 133 to 161 tons, and all of a hundred and sixty horse-power.

These seem mere cockle-shells wherewith to encounter a storm in the Straits of Dover; yet, after nearly thirty years of good work, they are still running, and, what is more, make the night mail passage to or from Calais-the shortest navigable distance being $22 \frac{1}{4}$ miles-usually in about an hour and threequarters. The Samphire indeed, on February 14, 1895, accomplished the voyage in less than an hour and a half, and the Maid of Kent, having lately come out of dock, I dare say does as well. But this is far from approaching the unsurpassed performance of the Calais-Douvres on the day service, when, on June 14, 1889 , she crossed in an hour and two minutes.

For many years the night mail-service, under the contract of March, 1878, cost no more than from eight to ten thousand pounds a year. But the price since then has gone vigorously up. Under a new contract of January 15, 1894, the London, Chatham, and Dover Railway Company, for conveying the night 
mails, receive a subsidy of twenty-five thousand pounds a year. In the old contract the time allowed for the performance of the outward trip was two hours and five minutes, and for the homeward trip two hours and ten minutes; under the new eontract an hour and three-quarters is allowed in either direction.

Having regard to the highly important character of the Dover and Calais mail-service, and to the speed at which the new packets, about to be placed on the Holyhead station, will probably cross St. George's Channel, it is not too much to expect that the new century shall scarcely have begun before the English Channel will be habitually crossed in an hour. 


\section{[ 94 ]}

\section{CHAPTER VII.}

BY THE NEW FOREST.

'D.L.T.A.R.' was the sole text of a cabalistic telegram which, in the forties, I used to receive every morning from Southampton, in the telegraph office at Waterloo Station, and send upstairs to the General Manager. In after-years it transpired that the message merely meant that the Dorchester Line of Telegraph was All Right. So much for a mystery!

If such were my introduction to official life, before I became a postal servant, almost my last act, under the Postmaster-General, was in like manner associated with Southampton and the skirts of the New Forest, inasmuch as when I was about to leave the PostOffice in 1893, we began to consider, in connection with the parcel post, the expediency of reviving the mail-coach service to Southampton. There was even the idea that, by means of the ordinary mailcarts, we might collect and deliver parcels in connection with it throughout the district of the Forest itself.

For the first thirty miles from the Post-Office we 
should probably have traversed the old well-worn Salisbury and Exeter mail-coach road-passing from London by Kensington Palace Gate, through Hounslow, over the Thames at Staines, by Virginia Water, and so to the Golden Farmer. This is a little wayside inn near Bagshot. It is a landmark of some importance to travellers, for near the inn the highway divides, the main line going on to Basingstoke, the branch diverging due South.

The Golden Farmer has had a share in the history of the road; for there was a time when Turpin (affecting all mail-coach routes out of London alike, and being engaged on business which admitted of no delay) frequented Bagshot Heath and Hartford Bridge Flats, and stabled his nag at this inn.

It was a vantage-point: he could take either the Basingstoke road and look after the Falmouth or Devonport mail and the night coaches and postchaises which kept the way busy and profitable, or, if disposed towards a quiet evening, he might amuse himself with the watches of sober folk making for the New Forest. If, again, he was in good trim, his purse low, and Black Bess in high fettle, was there not the main road to London at his disposal, and his Majesty's mails both going and coming?

The parcel coach would have gone over the river Blackwater and through Farnham and Winchester to Southampton-a distance from St. Martin's-leGrand, as nearly as possible, of eighty miles. This was the route of the old mail-coach, which, leaving 
London at eight o'clock p.m., was due to arrive at Southampton at half-past four in the morning, and was continued through the Forest into Poole. There is, indeed, a slightly shorter cut to Southampton from Farnham, through Alton and Bishop's Waltham, by which about a mile and a half may be saved; but this road omits Winchester, leaving it as much as ten miles to the restward, and such omission did not suit the department in the old days, nor would it do so now.

In Southampton, in 1586, lived Chidiock Titchbourne, a member of a family which dated from before the Conquest. D'Israeli, in his 'Curiosities of Literature,' dwells fully on the tragedy of his death, but does not say precisely where he resided. $\mathrm{He}$ could write with 'sweetness and tenderness,' says D'Israeli, who had found a letter of Titchbourne's in the Harleian MSS.; but nobility of mind and a cultivated intellect only served to bring about high treason (he stooped to a conspiracy against the life of Elizabeth), a sacrifice to friendship, the Tower, and a last scene in Lincoln's Inn Fields.

Three hundred years later the public, as most people will remember, were absorbed in another Hampshire episode. A fraudulent claim plunged the Tichborne estate into an enormously expensive litigation, which ended in the chief conspirator suffering a long imprisonment, and capping his career by publishing, in 1895, an affidavit which told the world what all reasonable people must long have 
known of the imposture which had been carried within measurable distance of success.

There are two roads from London to Poole on the western side of the Forest. The longer goes from Winchester, viâ Romsey, and then winds by forest glades to Poole.

At Romsey was to be seen, in the old mail-coach days, an apple-tree on the roof of the abbey church, which had grown there from an unknown date. A lady still living in Romsey (daughter of the postmaster whose office arrangements I inspected in the seventies) recollects eating apples from this very tree. It probably disappeared when the roof was renewed, some time in the fifties.

In those days the up and down mail-coaches passed through Romsey in the night; the mails were habitually hauled up to or lowered from the bedroom window. Heavy-eyed with sleep, after a long country walk, the postmaster once let down in error, as the Postmaster of Barnet had done, a domestic bundle, which, on the arrival of the coach in London, puzzled the 'tick' officer not a little.

These droll mis-sendings still continue, but in other ways. The sorting-carriage which runs nightly from Manchester to Crewe picks up, by apparatus, bags from some of the principal Cheshire towns which are not on the direct mail line of railway to London.

The bags are brought some miles by horse and cart to a wayside station, and the driver of the mailcart, after packing them in leathern pouches, 
transfers them, by means of the apparatus, to the sorting-carriage as the train passes by. On one occasion the clerk who opened the pouches so received was surprised to find that, in lieu of a mailbag from Macclesfield, the driver of the cart had carefully packed up the nose-bag containing his horse's feed. Consequently the poor steed lost its supper.

Winchester is not without its recollections-though they are fast fading away-of the Southampton mailcoaches. There is still preserved a specimen of the numerous copper tokens which at one time were freely issued, perhaps as advertisements. This, one, however, was struck in honour of 'J. Palmer Esqre. . . . as a token of gratitude for benefits receired from the establishment of mail-coaches.' On the obverse is the presentment of a coach and four horses in the act of trotting. The designer must have been a sound political economist, inasmuch as he adopted as the legend the words: 'To Trade-Expedition. To Property-Protection.'

More interesting still, in the cathedral close, is a moss-grown tombstone inscribed with lines to the memory of the last mail-coach driver on this road. Whether he drove the Red Rover, I cannot say, but such was the name of the last mail-coach from London to Southampton by the Farnham road. It ran to the old White Hart in Winchester, where I have stayed, but which, like the coach and its driver, belongs alone to the past. 
The slightly shorter way to Poole is through Cadnam, by way of Stoney Cross and Picked Post to Ringwood, and on by Ashley Cross.

Stoney Cross was rather an important point when coaches ran, because it was the changing-place between Southampton and Ringwood, $19 \frac{3}{4}$ miles. I can remember nothing but a low-roofed, straggling inn, not very far from Cadnam, with abundant out-buildings, almost in the Forest, and close to the Rufus Stone. Here Field-Marshal H.R.H. the Duke of Cambridge held his last review of a large body of troops.

The memorial, put up by the Lord Delawar of about a century ago, to commemorate the death of the Red King (William II.), from the arrow of Sir Walter Tyrrell, is supposed to occupy the site of the historical tree. But when I was last in the Forest, not alone the tree, but even the stone had vanished. It had been encased in an iron covering calculated to resist the knives and chisels of those intelligent wayfarers who, with a fine taste, generally leave to posterity, when they have the chance, their interesting initials cut into objects of historical importance.

By a singular coincidence the decline of mailcoaching was the signal for a rapid increase in the trade and population of Southampton. Coaches apart, two epochs, as essentially connected with the mailservice as with the prosperity of the town, occur in its history, and seem to stand out with distinction from other local events. The opening of the London 
and South-Western Railway in May, 1840, allowed for the first time of the delivery of the mails by rail from London in the town itself ; and the anchoring, a year or so later, in Southampton Water of the first mail-packet which the Peninsular and Oriental Steam Navigation Company sent into the estuary, marked the rise of Southampton as a great port.

When Lieutenant-Colonel Paterson compiled his road-book, the most he could say about the packetservice from Southampton was that soon after the arrival of the mail-coach from London, a packet sailed every morning for Cowes, in the Isle of Wight, and returned to Southampton, in winter at three, and in summer at four o'clock.

That was the egg which, being warmed and hatched by the enterprise of shipping companies and the town of Southampton, has developed into a bird of stupendous dimensions. The little Isle-of-Wight service still goes on every day except Sunday, and it calls on Parliament annually for a modest vote. But fleets of floating palaces passing to and fro between Southampton and the ends of the earth overshadow the Cowes boat, and unduly dwarf its importance and antiquity.

The earlier event, viz., the opening of the railway, resulted in benefits which at once came home to every one but those associated with the coaching interest (who of course saw no good in it). At a swoop the journey from London-from the PostOffice, from the Spread Eagle in Gracechurch Street, 
the Bell and Crown in Holborn, or the Cross Keys, St. John Street-instead of taking nine hours, was reduced to about three. The night-mail traveller found himself snug in his bed at Southampton soon after midnight, instead of shivering outside a coach on Bentley Green, below Farnham, and he was well through his beauty sleep by the time the mail-coach and its drowsy insides had caught a distant glimpse in the moonlight of Winchester Cathedral.

In a word, the eight p.m. coach at its best arrived at 5.30 a.m.; whereas the 8.50 mail-train from Nine Elms got in at seventeen minutes past midnight. Perhaps I may as well contrast the up-service. The mail-coach started from Southampton, driving through that splendid avenue of trees on the London Road, which is still in full vigour (though some of the giants have gone), at 9.18 p.m., darkness, however, shrouding the view, and got to St. Martin's-le-Grand about 6.22 next morning; the train left at 1.15 a.m., and reached Nine Elms at 4.25 .

The Dolphin in the High Street, which preserves to this day all that is best of the quaint, cosy, oldfashioned character which I had remarked in it forty years ago, was the head and front of the coaching and posting business. It also provided for part of the mail service. But the Coach and Horses, Above Bar, now a music-hall; the George, just above Bar Gate; and the Star, in the High Street-all of which exist-had also a share. In its day the Dolphin, at election times, has had its windows handsomely 
smashed by the rival faction for housing politicians of the wrong colour.*

The opening of the docks and rail, however, were the turning-point of postal prosperity. Up at a bound went the number of letters and the population. When the century began, Southampton was but a small town, up a muddy creek, and contained less than eight thousand souls; while coaches were in high career its inhabitants were a bare twenty thousand; when the railway had opened, and the docks had got well to work, they were nearly forty thousand; and now, in 1895, with the Channel dredged and deepened, many of the shoals cut away, acres of fine deep docks available, and at hand an unsurpassed service of railway trains, running at high speed, there are not fewer than seventy thousand people in Southampton.

Of all my recollections of post-towns out of Herts, Southampton stands earliest. In the late forties, after a short service at Waterloo terminus, I used to receive at the General Post-Office telegrams brief and to the point, such as :

'Cooper [or Williams],

Southampton,

to

Post-Office,

London.

'Arrived the West India mail. Despatches by mail train ;'

* While the bombardment went on, a lady of my acquaintance had the singular experience of sitting within one of the rooms which sustained the attentions of the mob. 
or, anticipatory and ornate :

'Postmaster,

Southampton,

to

Post-Office,

London.

'The Peninsular and Oriental Steam Navigation Company's steamship Ripon, with the Indian mail on board, now coming up Southampton Water.'

Postmaster Lankester, nominated by the Treasury, and strange to his work, fortunately had two capable assistants, Messrs. Cooper and Williams. As Lord Hammond of the Foreign Office stated of himself and his colleague, they divided the world between them, so far as the packet-service went. Lankester looked after the outward despatches, Williams the making up the mails, and Cooper and Williams the arrivals.

'It was at one time,' writes Mr. Williams, 'part of my duties to meet the P. and O. steamers at the Motherbank, where they had to perform quarantine, and to bring the mails to land. For this purpose the company supplied me with a sailing yacht of about eighty tons, and subsequently with a small steamer.

"We used to cruise up and down the Solent both in the summer and winter, looking out for the steamer. We then followed her to her moorings, and attached ourselves to her without allowing her crew to touch a rope. The bags and boxes were then shot down a gangway into our vessel, after having received a baptism of hot vinegar. Many a night have I passed lying on the boxes during the run to Southampton Pier, perfectly regardless of plague or yellow fever.

'The mail-coaches, from west to east, passed through Southampton to Portsmouth, Brighton, etc., and travelling as they did over Salisbury Plain, used to carry mail-bags hung over the guard's seat, and therefore in winter much exposed to the cold, so that in sorting the letters one seemed to hold lumps of ice in the hand.' 
The varied service of the immediate predecessor of the present Postmaster of Southampton gives a good idea of the training which administrative officials got in the old days, and still in some degree get (though not to anything like the extent which I think would be advantageous to the department), while serving their novitiate.

Mr. Pellatt entered the Post-Office in January, 1838. He was sent to Bury St. Edmund's to assist a Surveyor in the duties of his district. The first thing that this youth of seventeen had to do was to go to Weedon, and constitute that place as a posttown. He writes:

'In January, 1839, I was sent into the home district, to induct the new deputy of Luton. In those days the term "postmaster" was not used. Before I had been at Luton many days Mr. H. Mellersh [afterwards Assistant Army Postmaster in the Crimea] brought me a letter from Colonel Maberly, directing me to go to the northern district of Scotland. At Perth, the headquarters, I remained until I was ordered off into the South Wales district to take charge of the Pembroke post-office, where I remained till the latter end of November, when I travelled back to London by mail-coach, the journey occupying two nights and a day.

'I remember going, early in 1840 , to Lynn to see the effect of the introduction of Penny Postage on the duties of that office. Mr. Robinson Crusoe was the then postmaster. [He must, I apprehend, have long been back at home from the posts of Juan Fernandez, though Mr. Pellatt does not refer to the fact!]

' In November, 1840, I once more was sent off to the southern district of Scotland, and next to the eastern district.

'In January, 1851, I took charge of the office at Stevenage. The postmistress was at the point of death, so the office had to be removed to my lodgings. I had the whole of the duties to 
perform myself, both night and day. The up and down mailcoaches passed through during the middle of the night. I was thus prevented from going to bed. During three weeks I never once went to bed. I had about two or three hours' rest on a couch out of the twenty-four hours. The effect was intense pain in $\mathrm{my}$ feet; they were so tender I could scarcely bear the weight of my stockings.'

Falmouth was still the port for the Indian mails when the Peninsular and Oriental Steam Navigation Company first established themselves at Southampton. The letters* of the learned German professor, Dr. Richard Lepsius, furnish a time-bill of the outward voyage to Alexandria. He sailed from Southampton on board the Peninsular Company's steamer Oriental at ten a.m. on September 1, 1842. Bunsen saw him and his companions off.

It reads oddly now that because the wind was against them they did not reach Falmouth for a full day afterwards. There they lay for about five hours, awaiting the London mail. At three o'clock it arrived. After touching at Gibraltar, the Oriental reached Malta on the 11th. Here the voyagers were compelled to wait nearly three days for the post viâ Marseilles, the journey from London to Paris alone then taking thirty-one hours. On the 18 th the steamer reached Alexandria.

Of course there still is, as there was then, a despatch of Indian mails through France. Then it fell in at Malta or Alexandria with the boat from Southampton. In the fifties, Sir Rowland Hill took the oppor* 'Letters from Egypt,' etc. Bohn, 1853. 
tunity of a change in the arrangements to give some of his young men a run with the overland mail to Egypt. That was a journey to be remembered. The late Edmund Yates was one of the selected group. His trip extended to Cairo. He wrote a graphic account of it which appeared originally in Household Words, and afterwards in a collection of his early pieces, entitled 'After Office Hours.' I had the good luck to be sent to Egypt too.

The charge of my seventy-eight boxes of mail-matter was, until I got them safely on board the Vectis at Marseilles, an exciting responsibility. A count of seventy-seven at one point and seventy-nine at another added, especially in the case of one short, a not always welcome zest to the proceeding. At London Bridge, Dover, Calais, Paris, and Marseilles the count was a critical moment; and riding in the mail-van with the boxes through France, I furtively took now and then a supplementary opportunity of overhauling my charge. It was a moment of thankful relief when the janissary at Alexandria sang out the Arabic equivalent of seventy-eight, and especially when her Majesty's Agent gave me a receipt in full for my despatches.

For many years the two lines of mail-packets in the Mediterranean were steadily maintained. The Southampton boats conveyed to Alexandria the bulk of the overland mail at the cheaper (sixpence the half-ounce letter) of the two rates of postage in force, and the boats from Marseilles to Malta and Alexandria took 
the later letters at the higher rate of ninepence or tenpence the quarter-ounce.

But in 1870 a material change was made. Marseilles ceased to be the mail-port, and Brindisi, further east, near the mouth of the Adriatic, was chosen in its place. This shortened the sea transit to Port Said in Egypt from 1,508 miles to 930-which was no unimportant gain. The last mail-packet left Marseilles on December 11, and the first packet sailed from Brindisi on December 30.

In 1880 yet another change occurred. Under the International Postal Convention, territorial transit rates had been reduced; and it was found possible to send all the correspondence for India, etc., overland throughout. Accordingly, on February 1, 1880, the Southampton steamers were released from contract obligations; and the Indian mail-line resolved itself into the Brindisi service alone. The Peninsular and Oriental Company had already transferred its marine headquarters to London.

It was a blow, I thought at the time a fatal blow, to the interests of Southampton when the P. and $\mathrm{O}$. Company removed their steamers from the Solent to the Thames. But I was mistaken. The port is more extensive-more important than ever.

For more than half a century the Royal Mail Steam Packet Company have been the steady friends of Southampton, sending thence their superb vessels to the Brazils and West Indies. The packets for the latter now make for Barbadoes as the West Indian 
port of arrival. In the old days they ran direct to St. Thomas.

Once Mr. Lambert, now Surveyor of the Post-Office in South Wales, and formerly on the staff of the late Mr. Kains, the West Indian Surveyor, whose office was at St. Thomas, met with an uncomfortable experience. He had occasion, on the arrival of the steamer from Southampton, to go up with the mails from St. Thomas to Nassau, in New Providence, the most northerly of the Bahamas Group. Her Majesty's packet was then a small schooner.

' IVe were crossing the Bahama Banks,' wrote Mr. Lambert to me, 'by a course which is rarely taken by small coasters, but which saves about forty miles. The water is no great depth, and so clear that you can see every stone on the bottom, conchshells, and huge sponges such as you would pay a guinea for in England. The most striking sight on this occasion was a "school" of whales of the kind called black fish. There were ten or fifteen around us, and presently one came alongside the vessel so close that I could almost have jumped on his back. He was twice the length of the vessel, and glided past us, going our way without any apparent movement of tail or fin.

'So far all was pleasant. Not so the return trip.

'We started from Nassau rather late on a Saturday, and though the day was lowering and the wind not quite fair, the captain decided to cross the Banks again. The wind as we got on the Banks became more and more adverse; we could not steer a right course, and as it would not have done to get out of the proper channel with night coming on, the captain decided to anchor.

'The anchor was let down and the ressel rode to it for a time; but as the night wore, the wind rose and our little ship began to drag her anchor. More and more chain was let out, but all to no purpose; we were drifting fast, and every now and then we would pass a coral rock just awash, which would have torn the 
vessel's side out if we had touched it. Finding the anchor would not hold, the captain got several "pigs" of iron ballast and fastened them to the cable, each one about two yards from the other, and eventually, when captain and crew were worn out with fatigue and anxiety, the anchor ceased to drag, and our little vessel rode steadily head to wind. Then all but the watch turned in with thankful hearts and slept till morning.

'At daylight captain, crew, and myself turned out and began to prepare for a start. But it was not an easy matter by any means. We were all soon well-nigh exhausted. The labour of getting in the chain with the iron ballast attached was enormous, and it was not until I routed out three passengers who were in the cabin (two Wesleyan ministers and a reader), and induced them to help us, that we got our anchor up and our vessel under way. We had some very ticklish steering to get safely off the Banks, but once away from them and out in the deep, deep sea, although it was blowing hard, we were happy, because safe.

'After the little vessel was got into order and washed down, and all hands had breakfasted, the IVesleyan minister read the Sunday Morning Service, and followed it up with one of the best sermons I ever heard, preached without MS. or notes of any kind.

'Nassau was a very quiet, unimportant little place when I was there, but in the time of the American Civil WVar it became famous as the rendezvous of the blockade-runners.'

Stirring incidents may also be found in the experience of Mr. Turner, lately Postmaster of Leicester, who very many years was engaged in surveying the posts in Jamaica. There he, while officially employed, twice or thrice nearly lost his life from the torrential rains which occasionally descend on that beautiful island.

Once, after inspecting the post-office at Port Antonio, in riding up a ravine and attaining a height of two thousand feet, Mr. Turner felt the 
narrow pathway, weakened by excessive rain, slip from under him. His horse lost its footing; the rider, flinging himself off on the bank, just contrived to save himself, while the unlucky steed fell sheer two hundred feet, and then into the bed of a torrent lower still. Negroes working in a coffee-patch near at hand went down for the saddle and bridle, but the poor horse had, of course, met its end.

Again, on Mount Diablo, near Kingston, Mr. Turner was riding on horseback, also during heavy rain, in front of a carriage which was descending the mountain, when suddenly he found himself shot forward as from a catapult, horse and rider being both knocked down by the horse and carriage behind rushing down the smooth road, rendered slippery by wet, and cannoning against them with irresistible force.

On the other hand, he once experienced a pleasant imprisonment in the Rectory of Hope Bay, as, owing to the rising of the rivers between Hope Bay and Buff Bay, he could neither get back nor go forwards. The Rector made him his guest, and, until the water's subsided, lavished on the Post-Office official hospitality which has never failed in Jamaica, in spite of the varied fortunes of that magnificent but, since the abolition of slavery, not always prosperous possession.

Another steady friend of Southampton is the Union Steamship Company, which has developed from small things to great ones-from the Roman of eight hundred tons to the Scot of seven thousand. 
Other mail-carrying lines enter the port of Southampton-some as callers, some to stay. The Inman Line, changing its name and its port, now sails its ships under the American flag, and has left Liverpool for Southampton. The North German Lloyd steamers also call here for mails and passengers.

Southampton has been the scene of many sorrows, as when the Amazon was burnt at sea, and the Rhone went down at St. Thomas; and those who saw the crowd of grief-stricken applicants at the steamship agents' offices or around the dock-gates, when the heavy news came in, will not readily forget the sight. It has had its moments of triumph, too-when the Sovereign in person opened the new dock; when, again, the first ship of the United States' transplanted line, with the American mail on board, was, in the language of the advisory telegrams of my youth, 'steaming up Southampton Water'; and when, quite lately, T.R.H. the Prince and Princess of Wales opened there the largest graving-dock in the world, 750 feet long.

The telegraph-service, too, at Southampton has had its romance. At the entrance of the Solent, on a little promontory which juts out from the New Forest, is a solitary isolated fort-Hurst Castle. There is, or was when I went there twenty years ago, a rambling building near at hand, which serves as offices, and perhaps as barracks. In this building a steady young telegraph clerk, belonging to the Southampton office, was employed in the seventies to signal the 
passing of the mail-steamers up and down the Solent. For some time it was noticed he had been depressed in spirits. He declined to join a projected staffsupper on pay-day at Southampton, alleging that on the day appointed he would be quite unable to attend. This was but too true.

When the end of that particular day came, the current work (it was afterwards found) had been scrupulously completed, the day's messages neatly collected and arranged in the customary parcel, the diary entered up, the instrument left in good order, and the office trim and neat. At the proper timeeight o'clock-but not before, the young man went off duty. Next day his hat was found upon the beach, but he himself was never seen again.

The mystery remains unsolved, though at the time it was generally thought that the old, old story had embittered the young man's life.

I recollect that, at the time of my visit, it was said that the "Woolwich infants' in position were too short for the battery. What would happen to the embrasures and artillerymen on the occasion of ball practice or a salute was an interesting problem. But, at the worst, it could only have been the platforms, not the guns, which needed correction.

Southampton supplies a singular example of the law of averages. A recent return to Parliament shows the average time occupied during the year 1894 in conveying the American mails, via Southampton, by the United States steamers Paris 
and New York, between the General Post-Office in London and the Post-Office in New York.

The distance from St. Martin's-le-Grand by way of St. Paul's Churchyard and Blackfriars Bridge is-to Waterloo Station, and thence by rail to the ship's side at Southampton, $80 \frac{1}{2}$ miles; from the dock here to the quayside there is 3,069 nautical miles, and I suppose it is half a land mile further to the New York post-office-total $3,613 \frac{1}{2}$ statute miles. The mails carried by these two vessels respectively covered this great distance, on an average, outwards, in 7 days 6 hours 55 minutes; and despite fogs, storms, icebergs, or what not, on the Atlantic, the road up or the way blocked in Queen Victoria Street or on Bennet's Hill, the bags achieved the inward journey in 7 days 6 hours 56 minutes.

There was only in point of time a minute's difference (on the average of a year's runs) between taking the mails $3,613 \frac{1}{2}$ miles in one direction, and bringing them $3,613 \frac{1}{2}$ miles in the other. As the service is not performed under the British flag, I cannot say whether the same course, and therefore the identical mileage, is covered on the outward as on the return trip; but the distance named appears to be, at any rate, the mean or average distance.

On June 13, 1895, a brand-new steamship of 16,000 tons, according to one account, and therefore the largest vessel afloat, or of 11,000 tons, and still one of the largest according to another (the former figure probably representing builder's measurement 
and the latter registered tonnage), brought mails and the British Ambassador from New York to Southampton. This arrival may be accounted the first-fruit of that active competition which is designed to place the Hampshire port (by the way, there is legally no such county) in the fore-front of British harbours, and utilize to the full the 'longest graving-dock in the world.'

No wonder that the Town Council of Southampton desire to express a grateful appreciation of the services rendered to the port by the London and SouthWestern Railway Company ; and to confer, in proof of their sentiments, the honorary freedom of the borough on Mr. W. S. Portal, the Company's Chairman. 


\section{CHAPTER VIII.}

THE CORNISH MAIL.

Tastes of course differ; but in my opinion there are few more attractive spots than the Lizard Head, on the coast of Cornwall. It is eighteen miles from Falmouth, and eight or ten from Helston. The Lizard 'Town,' as it sees fit to call itself, is perched high up on a tableland, at the verge of the great Goonhilly Downs, overlooking Mount's Bay, the offing of the Fal, and the English Channel generally.

Here I have retired to consider and concoct many a piece of official scheming, and occasionally from the signal-house on Beast Point, which was once in possession of the Post-Office, have watched and signalled the mail-steamers as they passed to and from Plymouth and Southampton.

At the same time, the reader must not be led away by my personal predilection for the Lizard to assume that it has a band and a pier, or even bathing-machines and broad sands. Far from it! The best walking-places are on the tops of the hedges, and although one may bathe in comfort at Kynance 
Cove, even there, picturesque as the cove is itself, the sands of this splendid, health-giving, rock-bound coast are not much to speak of.

I recollect the late Rector of Llandewednack running breathless into Penmenner, where I was staying, to say that the beach near the lighthouse was being carried bodily away. A neighbouring farmer had moved off with a single cartload of sand.

Lizard Town viewed with lordly indifference the goings and comings, at Falmouth, of mail-coaches, which never dreamt of approaching the Lizard; and, so that she got letters now and then, it mattered little to her how she got them. The workers in serpentine were not much concerned in correspondence. Besides, they had the life-boat, which lies under the lee of the lighthouse, to look after. Enough for the day were the cares thereof.

Not so, however, at Falmouth, Penzance, Truro and the like. To them, a swift post was of the greatest consequence. Falmouth especially looked on the quick running of the mail-coach through Cornwall as the best guarantee of the success of the great docks then in view. Truro took thought for its tin.

So, hardly had Lord Lichfield, as PostmasterGeneral, taken up the reins at St. Martin's-le-Grand, when the southern towns of Cornwall, by the united voices of the High Sheriff, two mayors, ten magistrates, the clergy, the gentry, bankers, solicitors, and others, made a powerful appeal. They deprecated the circuitous and hilly route of Salisbury and Yeovil 
for the West of England mails, and besought that the Quicksilver royal mail-coach might follow the shorter route of Ilminster taken by the Telegraph, and that the bags might be sent forwards from Devonport without the delay of a night.

The Post-Office was nothing loath. The officials threw themselves con amore into the work of acceleration. They and Lord Lichfield were in constant communication. The first point was to determine the shortest road to Exeter from Andover, which was a coaching town of no mean consequence. Men yet living in Andover recollect a coach passing through it at every hour of the day and night. Some of the famous inns still stand. The White Hart, in Bridge Street, is yet as it was of old, and the Star, in the High Street, to which the noted Telegraph ran, is little altered. But the Catherine Wheel, at which the still more noted Quicksilver changed horses, though it remains in Bridge Street, has fallen-some may think risen-from its former estate; half is a coffee tavern, the other half a reading-room.

At Andover, in the old electioneering times, a singular incident occurred. Sir F. B. Delaval's agent, an attorney, conceived the notion of inviting the officers of a regiment quartered in the town to a good dinner at the George, in the name of the Mayor, and at the same time he invited the Mayor and Aldermen in the name of the officers. When the author of this practical joke was discovered, as he was soon after dinner, the Colonel, in wrathful reprisal, threw him 
out of the window, the unhappy attorney's legs being broken in the fall. In due course, an item appeared in the bill of costs against Sir Francis: To broken legs, surgeon's bill, and loss of time and business, in Sir F. B. Delaval's interests, $£ 500$.

This was deemed a monstrous charge. For my part, I think Sir Francis, if liable at all, got off very cheaply, inasmuch as I call to mind that when a chief official of the Post-Office, while inspecting a new line of telegraph in Suffolk, unhappily was thrown out of a dog-cart, and sustained a broken leg and other injuries, the doctor's bill alone came to a sum not very far short of the claim raised against the politician.

The two great authorities on main roads were Cary and Paterson. Cary had long been on friendly terms with the Post-Office. In 1798, when he brought out his 'New Itinerary,' and afterwards his ' County Atlas,' he declared them to be compiled from actual admeasurement, by command of his Majesty's Postmaster-General, for official purposes.

Again, on January 14, 1820, postmasters were directed by an official notice 'to give any information they may be able to Mr. Cary, in his inquiries about country seats or roads.' Now, although Cary had chained the minor distances with care, he was said to be not always arithmetically correct in computing the sum of the major measurements. Paterson, according to Lord Chancellor Campbell,* imitated Cary's Roadbook, even to its errors.

* 'Chancellors of England,' vol. vi., p. 562. 
Andover was an important point as a junction of highways, but the shortest cut from it to Exeter was uncertain.' A very careful investigation, however, shewed that the Ilminster route, branching from Andover, was the most direct of the three ways to Exeter. This road, after leaving Andover, sixty-seven miles from the General Post-Office, passes through Amesbury, Wiley, Mere, Wincanton, and Ilchester, and after traversing Ilminster makes for the Devonshire Inn and Honiton. The hostelry in the old days bore a thatched roof and a ponderous sign. Both have been removed. Seventeen years ago it was converted into a farmhouse, and the only characteristic relic of its past is the porch, with sitting accommodation for tired and thirsty souls who halted by the way.

By Ilminster, the new route proved to be only $103 \frac{1}{2}$ miles from Andover to Exeter, and so it brought the post-office at that city within $170 \frac{1}{2}$ miles of St. Martin's-le-Grand, as compared with $173 \frac{1}{2}$ viâ Salisbury and Yeovil, and 176 $\frac{1}{4}$ viâ Salisbury, Blandford, and Dorchester. When one looks at these roads on the map, the distance by Blandford seems much more than six miles the longest of all.

To the Ilminster road the Quicksilver-some of whose drivers are still living - was diverted. It rattled along at ten and a half miles an hour, continuing the service without a check to Devonport (and, indeed, by branch coach to Falmouth), and delivering the mails at Exeter in $16 \frac{1}{2}$ hours, at Devonport in 
$21 \frac{1}{4}$ hours, and at Falmouth in twenty-nine hours from the General Post-Office. This was a feat to be proud of.

I think it was at Devonport in the late fifties that a story was told of an assistant in the post-office, whom I will call Miss Bridget B. She was quite an original character, and was rather hostile to feminine customers.

In the rotunda leading to the counter at the Devonport post-office, a small pane of glass commanded a full view of the interior, and it was not at all uncommon for young women who wished to buy stamps or take out a money order, before venturing within, to peep through the glass pane. If the coast was clear, they would be heard to say: "She is not there now. We will go in.' Sometimes when they did get to the counter the lady had returned to her post, from which she kept a watchful eye on any attempt to approach one of the young men in attendance.

All the same, if Bridget, who had a soft heart under a harsh exterior, was rather obnoxious to the one sex, she was a favourite with the other.

One day my colleague was entirely disconcerted. She had admonished one of the stampers for some misdoing, when the reproved official tartly rejoined, 'Well, at all events, I never set the office on fire.' It seems that 'Sister' (her pet name amongst the staff) had a drawer distant from any gas-jet, where she kept a small mirror, a hair-brush, etc., and a piece of candle. In the absence of a candlestick, 
her method was to press open a neiwspaper, lying for delivery or despatch, and insert the candle in the folds.

This impromptu candlestick enabled her to compass some of the mysteries of the toilet; and it was firmly believed by the stampers and clerks that on the night of a fire, which actually did break out in the Devonport office, she had left the candle burning in the newspaper on closing the office.

Large placards were issued offering a reward of fifty pounds for the discovery of persons supposed to have flung lighted matches into the letter-box. But not a single person on the establishment breathed a suspicion. All were loyal to 'Sister.' It was not until after her death, many years later, that an old official cleared up the mystery.

The traveller may still encounter the inns of the old days on the great Cornish road to Falmouth and the Land's End. If Kelly's House, the first stage out of Launceston, is no longer an inn, but a factory, the King's Head at Five Lanes stands as of yore-a solid, square-set building, unchanged by sixty years of restful ease. Jamaica Inn, now a temperance hotel, was built by a retired Jamaica settler. Because of its erection at a spot where the great road traverses a desolate moor, the good folk of Altarnum, hard by, said it was 'a bould ventur.' In course of time a village sprang up around the inn, and ' a bould ventur' gave place to the good Cornish name of Bolventor. Should 
anyone assail the solid foundations of this story, I might triumphantly retort that on Stockdale's careful map of 1824 there is to be found Jamaica Inn, but no Bolventor, and that on the new Ordnance map of 1889 will be found Bolventor, but no Jamaica Inn.

Indian Queen, at the extreme south-east corner of the parish of St. Columb, is not only an inn, but a village. Let a Cornish colleague of the past tell the tale. He says :

'I lived for twenty-three years within three miles of the place, and have spent many hours in the old bar-parlour [enforeing, no doubt, the principles of sobriety and thrift]. I have been told by my father that Indian Queen was a very important centre in the old coaching days; as it was a sort of junction, where all the mails for St. Columb, Padstow, etc., were brought, and I think also for Wadebridge. When I first knew the place it consisted of the old inn and about a dozen houses, but now it has grown to quite a large village, with two chapels, a chapel-of-ease, a Literary Institution and News-room, etc., but still retains the old name of Indian Queen.'

In Truro the mail-coaches ran to the Royal Hotel, at the bottom of Lemon Street. At Falmouth they halted at The Green Bank Hotel, which stands at the head of the harbour, and still (as in the old days, when Commissioner Bowen surveyed the port and laid down buoys for sixteen sail of battle ships) opens its hospitable doors to the traveller-that comfortable inn where guests stay as long as they can, and where servants remain for a generation.

As a fact unique at mail-coach inns, I will mention that the same official who filled the useful post of 
boots at this hotel, and collected the guests' letters for the North and London mails, before my first visit to Falmouth, in the fifties, is there still. He was boots before the railway was made from Truro, and when we could only reach Penzance by taking coach across to Redruth (whence may be seen the English Channel in the east and the Atlantic in the west). $\mathrm{He}$ is a faithful servant of the establishment ruled by the genial Mitchells-the father in the past, the daughter in the present-to this day.

Tribute has already been paid in another work to the extreme sagacity of mail-coach horses in Scotland. A colleague of the past relates a story of remarkable intelligence shown by an English horse drawing a mail-cart forty years ago in distant parts of Cornwall. It is best told in the postmaster's own words :

'Back in the early fifties, I was the clerk at Truro, and passing rich on fifty pounds a year. It was my duty, in addition to sundry odd jobs during the day, to do the whole of the night sorting, and to take charge of the office from ten p.m. to five a.m. At that time Truro was the forwarding office for all the district westwards, and the correspondence for all the North of England and the Midlands passed through it. There was a mail-cart which left Penzance at ten p.m., and leaving Hayle, Camborne, and Redruth en route, arrived at Truro at two the following morning. This was the up North mail, forming a junction with the coach starting from Falmouth at two a.m., and covering the ground to Truro in a single stage. The driver of the cart was one of the hangers-on to be found attached to almost every country inn. Half stable-boy, half boots, he was a sort of man of all work, and could do anything, from driving a pair of horses to waiting at table.

The twenty-six-mile drive from Penzance to Truro in the 
dead of the night was a wild and fearsome journey. Skirting the shore of Mount's Bay, without as much as a broomstick to shelter him from the fury of a south-east gale, the driver met a branch eart on Marazion Green, and took over the correspondence from the Helston and Lizard district. Crossing the causeway, over the Hayle district the roar of the breakers could be distinctly heard, thundering against the ironbound coast. Connor Downs brought him to the once prosperous mining district of Camborne and Redruth. The clatter of a thousand stamps, pounding the ore, and the giant arms of the pumping engines rising and falling with every stroke of the piston, gave the country a weird and unearthly aspect, and this was not improved on his passing through Scorrier and Chacewater, where, for many generations, human moles had been burrowing for tin and copper, and had left the surface defaced with huge piles of attle-monuments of an industry now, alas! fallen into decay.

'One dark and stormy night, having done the work up short, I was listening for the horn which the mail-cart driver always blew to announce his approach. The horn was silent, but presently I heard the clatter of the horses' hoofs, and the rumble of the wheels as the cart drew up at the office door. After waiting some time and finding the driver did not bring in the bags as usual, I went out, and there he was, helplessly intoxicated, leaning forward against the splashboard. I tried to arouse him, but the case was hopeless; so getting the key, I examined the cart, and found he had no mail from any place nearer Truro than Hayle. And here comes in what I venture to think is an extraordinary instance of sagacity and intelligence on the part of the horse. The driver had dropped off to sleep shortly after leaving Hayle, and lay a helpless log for the rest of the journey of nearly twenty miles. The horse had pulled up at every turnpike, stopped the regulation time at each post-office [where it was the practice of the Postmaster to leave the office door unlocked, and hang the bags on a peg behind it, so that the driver might help himself], trotted into Truro, and pulled up at iny office to the minute.'

There is not a more temperate, sober, and well- 
conducted class than the postmen of the United Kingdom, but here and there an exception may be found.

In Derbyshire a postmaster of my acquaintance had reason to suspect the habits of a postman who drove a mounted post. 'I will survey your round to-morrow, Harrison,' said the postmaster. 'All right, sir; I'll be ready at a quarter to six.' The morning came, the chaise was brought, and master and man started off.

'The pony goes well enough, Harrison; I will hold the whip.' Presently, as by custom, the steed, unchecked by lash, stopped at the Saracen's Head. After a great deal of urging, a fresh start was made, only to precede a second unauthorized halt a mile further on, at the Blue Boar. In short, there were four such points at which the pony was daily accustomed to halt and the thirsty postman to take morning draughts.

Seeing that I have (superfluously enough) testified to the postal merits of horses, I must go out of my way, as an act of bare justice, to refer to the services rendered to the department by another member of the quadrupedal family, viz., Jack, the wire-haired terrier, whose home was for many years in the New Bath Hotel at Matlock Bath, in Derbyshire.

This remarkable and most intelligent dog I am told has already been praised in print by a popular writer; but I draw my facts this very day fresh from the Bath itself. Jack never failed to meet visitors on their 
arrival and welcome them at the entrance to the hotel. He was always to be found the next morning waiting on the doorstep to conduct them to the post-office.

Then, like a dog of good business habits, after giving his clients time to attend to what posta! matters they had in hand, he was at their disposal as guide, philosopher, and friend, to accompany them in rambles around the lovely neighbourhood, and trot ahead on the most charming walks.

The old dog well knew all the best points in the vicinity, and, being but rarely swayed by the known proximity of choice bones, never took his charges twice over the same ground. In all this he showed a true regard for the postal revenue, which these lines seek to acknowledge; he first took visitors to the postoffice to buy postage stamps, and next led them walks, in giving accounts of which by post the stamps were necessarily used up.

Poor Jack, who met with a tragic end while in the bloom of old age, at twenty-two, led an eventful as well as an active life; inasmuch as he thrice narrowly escaped an accident which would have been fatal, only to succumb at last to what I trust was pure misadventure.

Parliament used at one time annually to vote eighteenpence a week as subsistence-money for a cat employed to catch mice in the Central Telegraph Station, which was in the nature of a reward to an individual for eating his own bread and butter. But there was no vote for Jack in recognition of 
his revenue services; the member for his division might at least have put a question on the paper, and mildly harassed the Government of the day in his interests. But, as it proved, he was not even given the run of his teeth now and then in the Perishable Articles branch of the Returned Letter Office, as a national, if honorary, servant and deserving dog might reasonably have expected.

Having referred to the sagacity of horses and dogs acting independently, I am impelled to give an instance of collaboration. A public carrier, proceeding to Dumfries, had as passenger a young woman ; as freight, a pony tethered to the cart; and as guard, a dog. He called at a house to deliver a parcel, and when he came back, all three were gone. Ultimately he discovered his horse in a stable near Dalbeattie, the dog holding him fast by the bridle, and the young woman in safe custody.

This gamesome damsel had for a frolic loosened the halter and sprung on the pony's back. The latter, seizing the opportunity, tore away full gallop towards his distant home; the dog, seeing a part of his charge in the act of desertion, dashed off in pursuit, overtook the runaways, sprang at the halter, seized it in his teeth and held on, checking the pony's speed, to the last extremity. The girl's screams brought wayfarers to the rescue, and so came safety and an end of the story.

However, to get back to the far-away duchy. Cornishmen are proverbially tender-hearted; still, 
years ago it used to be a subject of speculation how it was that lapses of punctuality in the post from St. Austell to Higher Sticker gave rise to little or no complaint. The delivery was made by a small, weakbacked, not very physically-fit man; and it was supposed that the sympathy of those he served caused them to refrain from grumbling at late arrivals of correspondence. The office, too, looked aside as far as it properly might. When it was obliged to take notice, his poor back was the invariable excuse. 'One day,' writes a correspondent, 'when I had to speak to him more seriously than usual, he said, "Well, I will tell you the truth: there were more people than usual on my round that day who wanted shaving." Now, as the masculine part of the population cared just as much about being shaved as about getting their letters, no complaint arose. Pity kept the others silent. The invalid had for years combined the duties of a rural postman with those of a barber, and had stayed on his rounds to shave or cut the hair of any who needed the tonsorial office while he should have been delivering his letters.'

The times, one need not write, are changed since June 18, 1821, when Thomas Carlyle, at Edinburgh, explained to Jane Carlyle, at Haddington, the delay in the arrival of 'Nochden's German Grammar' by the fact of the London smacks being all becalmed.* They are changed not only as regards postal methods affecting the North, but as regards Cornish posts too.

* 'Early Letters of T. Carlyle.' Macmillan, 1886. 
In 1821 the London mail did not reach Penzance until late in the evening. Letters which left London on Monday, and arrived on Wednesday night, could not be answered until Thursday night, and the answers did not reach London until the following Monday.

A letter posted in time for the first despatch from London on Monday morning would now reach Penzance early enough to admit of a reply being sent by the mail which is delivered in London on Tuesday evening. By taking thought, it is also possible to arrange that a letter sent by the last despatch from London on Monday night shall secure a reply by the last delivery on Tuesday night-one day instead of seven days for the complete course of post.

Though instances can be indefinitely multiplied, it may be added that the times are also changed since an old lady, still living at Bamborough, who knew Grace Darling, could most cheaply send a pair of boots to a sister in service by carrier to Sunderland, and thence by smack to London, conversely as Carlyle obtained his 'Nochden.' The parcel post takes books or boots, if need be, from door to door-from London to Bamborough or Edinburgh, from John o' Groats to the Land's End-in a few hours for a few pence.

Of the days when the Post-Office sailed its own packets to places beyond sea, the historian of the Post-Office, Mr. Herbert Joyce, in his admirable and exhaustive work, makes effective mention. 
I will do no more than preserve the names of two gallant men-the Captain, Norman, who fought and died, and the Naster, Watlins, of twenty years' service, who fought and lived, on board the Falmouth packet Montagu.

'Teneriffe, Nov. 9, 1813,' writes Watkins. 'We arrived at Madeira on the 1st, and landed the mail. At four a.m. on the 2nd were attacked by an American privateer schooner-exchanged broadsides. The above quitted at nine p.m.

[A broadside more or less seems to have been of little moment to the old salts of the Montagu, and all in the day's work.]

'The 3rd at eight a.m., a schooner astern, coming up fast. At three-ten commenced action. At three-twenty-five schooner boarded with a large body of men on the starboard quarter; her jib-boom in our main rigging. Captain Norman, surgeon, two seamen, killed, and four wounded. We at last succeeded in clearing our decks; three-thirty-two p.m., the schooner got on our larboard quarter and boarded with great superiority of men. The Montagu only thirteen men left; myself at that moment wounded in left hand and thigh. I ordered the mail to be sunk; (aided by Almighty God) we succeeded in clearing our decks. We manned the guns on the side of the enemy, and had soon the satisfaction to see the schooner walk off from us, leaving us without a brace or bowling unshot.'

The stout Montagu's losses in the action were four men killed and twelve wounded-eight, including the brave master, dangerously. Only five sound seamen were left to fight and sail the ship. Before Watkins, disabled, quitted the deck to go below, he 'gave orders to the gunner, who came out of the magazine at that moment, that the colours were never to be hauled down as long as a man remained; that I would be with them presently.' 
' Fight on my men, Sir Andrew sayes, A little Ime hurt, but not yet slaine; Ile but lye downe and bleede a while, And then Ile rise and fight againe.'

The ancient ballad of Sir Andrew Barton, from Percy's 'Reliques.'

'During my stay below to stop my blood I was for some time insensible.' The stay below of the dangerously wounded man was not more than three minutes. "When I was lifted on deck, I saw the ensign on the quarter, and immediately ordered it to be secured to the starboard main rigging, which was done by George Butler, a black man.... The Montagu's guns never ceased firing. From the most gallant conduct I saw displayed from my friend and commander, Captain Norman, before he fell, I determined that the British flag then flying on the Montagu should never be disgraced by his successor.'

There was naturally not much delay about promoting Watkins as soon as he got home. 'It was Watkins,' wrote Freeling, 'by whose gallantry the enemy were at length beaten off, after a desperate and gallant defence.' 'Let Mr. Watkins' appointment' (as Captain to the Montagu) 'be made out immediately,' ordered Lord Chichester on January 29, 1814.

Posterity surely affirms both Freeling's tribute and the action of Chichester.

When the Post-Office packets at Falmouth were transferred to the Admiralty, in 1823, the packet agency was abolished as a separate institution. The 
agent, Mr. T. M. Musgrave, had seen a varied career -at one time in the Treasury and Lord Malmesbury's private secretary, then in the Alien Department of the Secretary of State's office, next packet agent at Lisbon, and then packet agent at Falmouth, where he was expected to extend civilities to distinguished strangers and 'speed the parting guest.' On the abolition of the agency, Mr. Musgrave was transferred to the Controllership of the Twopenny Post in London, in Gerard Street, Soho, and ultimately was appointed to be Postmaster of Bath.

Afterwards, at Falmouth, came as postmaster $\mathrm{Mr}$. Gay, whose son attained great popularity as a surveyor. Between the two the Gays' service in the department extended over more than seventy years. Gay senior was followed in office by Miss Jane Seymour Wood, who almost invariably witnessed the transfer of mails between packet and coach.

It is said that when the first outward Indian mail was put on board the packet at Falmouth, it was carried under the arm of Williams, coxswain to Admiral Ellis, superintendent of the port.

William Rufus Ellis, in the fifties, succeeded Miss Wood. Could William Rufus but have married Jane Seymour, there would have been a concurrence of royal names not usual in postal experience.

There are still numerous head offices in charge of postmistresses. The most considerable, I think, are Folkestone, under Miss Spearpoint, and Dorking, under Miss Lanham. 
At this moment the two head post-offices in the United Kingdom which have been longest under postmistresses are probably Penryn in Cornwall and Tuam in Ireland.

As far as I remember them, all the offices so controlled were models of neatness and good order. At Cirencester, indeed, when, about 1857, Mrs. Martha Squires was postmistress, the post-office was distinguished beyond all other offices in the fact that every bundle of letters was carefully wrapped up in blue paper before being despatched.

When, as sometimes has been the case, the expediency of dispensing with date-stamping has been advocated, the value of the practice from a legal point of view has generally defeated the innovators. Mr. Newberry Cox, the postmaster of Falmouth, would be an effective witness to call in such an inquiry. $\mathrm{He}$ has been able, when needful, to establish triumphantly the date of his birth by flourishing before authority a letter written (probably on Bath post, as was customary) by his father to his grandmother, announcing the fact of the grandson's arrival in the world, and the outer sheet of the letter bears a very distinct impression of the dated stamp of the Taunton postoffice of August 14, 1833. The production of this document has obviated the need of a certificate of birth, and has been always accepted as legal proof.

There was from the first a strong postal flavour about Mr. Cox's young days. His earliest experience of public life was to travel part of the way 
from Taunton to Falmouth, a distance of a hundred and twenty-three miles, by mail-coach. He left the former town with his parents in a specially-hired coach at ten-thirty a.m. on one day, and, changing vehicles, probably at Pople's New London Hotel at Exeter, got into Falmouth by the mail at half-past four the next morning.

Being a lover of salt water to the core, he stole away betimes, as soon as he could shift for himself, and found his sea-legs by roughing it all over the world. Mr. Cox, it is true, has not sailed the Arctic or the Antarctic Oceans, but certainly the North and South Atlantic, South Indian and North and South Pacific Oceans, the China Seas, and the Bay of Bengal were in due course traversed by the adventurous youth from Falmouth. The experience thus gained-unique in the case of a postmaster-stood him in good stead, when, in 1856 and later, his duty required him to be beating about in Falmouth roads, or outside, in the open Channel, waiting for the incoming or out-going mail-packets.

When I last saw Mr. Cox afloat, he was alone in his boat, running before the wind, and apparently endeavouring to measure its fitful force by laying the mast of his craft as nearly as possible parallel with the surface of the sea. He had taken me orer to inspect official arrangements at St. Mawe's, and we mere returning--he in a cockle-shell, I, less courageous, in a broad-backed steam ferry-boat.

I have borrowed the rough note-book of this inde- 
fatigable official, and now print a few of its introductory pages so that the reader may judge of what derolves on the postmaster of this ancient port.

'I was appointed,' he writes, 'Postmaster of Falmouth on July 19, 1856, being then between twenty-two and twenty-three years of age, and being told at the time I was the youngest head postmaster in the kingdom. I was to be on probation for a fortnight, and thus prove whether I was competent or not. The duties all being new, strange, and complicated, almost frightened me; but I thought what one man can do, another can ; so I gave myself up body and mind, and at the end of my probation was considered able and fit, and the office was handed over to me.

' My staff then consisted of my wife, myself, three town postmen, and three rural postmen-total eight.

- My hours were seren a.m. to ten p.m., with no time for meals but what could be caught between the sale of stamps, issue of money orders and other window duty; and here I would say every single penny stamp had to be cut from its sheet with a pair of scissors. The present perforation (a boon indeed to PostOffice officials) had not then been invented. I say seren a.m. to ten p.m., because the office was open to the public during those hours, except for a quarter of an hour to despatch each of two mails, and for an hour to sort two in-mails. The duties did not cease at ten p.m., inasmuch as at that hour the North mail was due by four-horse coach from Plymouth-there was then no railway communication below Plymouth. The mail never arrived within half an hour of ten, it was often much later. All the letters, etc., had at once to be stamped by myself and sorted off for the delivery at seven-thirty next morning.

- The foreign-ship letters charge generally amounted to ten or twelve pounds a day. Registered letters had to be separately entered on a green form, folded in it, and directed, this form being signed by the addressee and returned by the postman, the delivery receipt to be duly filed and kept for record. When this had been done, bags had to be made up for despatch at onethirty a.m. (up North mail, middle of the night, you see!) ; bags 
for Penryn, Truro, Grampound, St. Austell, Lostwithiel, Bodmin, Liskeard, Devonport, Plymouth, and London and Exeter Railway.

'At the best of times, if the work was kept up close to the hour of office-closing, and the North mail got in in good time, I might get out of the office by eleven o'clock, not fit for much, you may well think, except for supper and bed. Then at one-thirty a.m. the mail-guard would linock me up for the mails. On several occasions in the depth of winter I have had, when the mail due at ten p.m. had not arrived at one-thirty a.m., to go part way to Truro in the bitter weather, meet the down mail, send the guard back to Plymouth, and bring in the down mails. I wonder who would do this in these times? After despatching the one-thirty a.m. mail I was free until seven a.m.

'This continued until some time after the railway reached Truro-I think about four years, during which time I never failed to make the appointed despatch on one single night; which means I never had one fair night's rest during the whole time, and I did more than two days' work for every day, and at least six hours every Sunday. Here I would add that for the first twelve years of my service I worked double tides-that is, the hours covered were equal to twelve days a week, and Sundays beside; and for the first twelve years I was in the service I had no holidays whatever.

'During several years foreign mails were not only received at Falmouth, but were also despatched thence for the West Coast of Africa, Cape de Verde Islands, Brazil, and River Plate; West Indies, Cape of Good Hope, and the United States. For the Brazils we used to put them on board a steam-tug and go out to sea to meet the outward steamer, no matter what the weather might be.

'The last time I remember well. Mr. Robert Fox* was there. The night was coarse and dirty. We stopped out until about six a.m., then, as the steamer did not put in an appearance, we went ashore, and had just comfortably got to bed, when we were roused out and had to start again with the outward Brazil mail, the steamer having arrived.

* A member of the great Quaker family at Penjerfick and of a firm at Falmouth. 
' The years 1867 and 1868 were, I think, the busiest years for foreign mails. At that time we had a Cape of Good Hope, a Brazil, and a United States line, the latter two being royal mails. I had on one occasion, on one day, to deal with two outward mails and one homeward mail. How I got through I can't tell, for at that time no extra pay for help was allowed; and although I worked almost night and day, until later years, I got nothing extra for it; yet all was done without any hitch,

'I have on more than one occasion gone to London without breakfast, and back next morning, and attended in the office all day afterwards.

'In the year 1863 I had a curious experience, which I have always thought had some bearing on the closing of the American War.

'During the month of January, a large blockade-runner, a steamer called the Peterhoff, came in here. Several gentlemen landed from her, and came to see me at the office. After a chat, they told me they had a lot of documents they wanted to get into the Southern States to raise money; it was of the utmost importance that they should get them through the blockade; if I would put them in a bag, label and seal it for them, they would give me any sum I would take-I was to make up a false mail, of course. If I would do this, they could manage to get it through, and no one would be the wiser. I refused to do it.

' On the first occasion, they left saying they would call again next day. This they did for several days, telling me every man had his price. I told them, not an Englishman, and they would find it so. After calling for more than a week and finding it no use-trying all in their power; saying that money was no object: and that whatever I wanted I should have-the ship sailed, and I heard no more of them.'

Such has been part of the postal experience of Mr. Newberry Cox.

In August, 1882, having gone out to the Lizard for an official purpose, I was told by the sub-postmaster that a mail-steamer had come ashore a day or two 
before. I went across to the postal telegraph signalling station on Beast Point, a mile from Lizard Town, and could see nothing. 'Go to the cliff's edge,' said the younger Skewes, the signalman. I went almost to the edge, and still saw nothing. I took a step more, and looked over the edge.

There, two hundred feet below, was a great vessel of perhaps three thousand tons burden lying as though at anchor, her bowsprit touching the vertical cliff, her keel, alas! on the rocks. It was the North German Lloyd steamer Mosel from Southampton, bound for the port she never reached-New York.

Happily, there was no loss of life; passengers and crew alike were safely landed. As a means of reaching the Mosel, a basket had been slung on a hawser made fast to the mast and carried some way up the cliff. Looking down the precipice, I saw a young lady, the daughter of a neighbouring vicar, promenading below on so much of the deck as was not awash, having adventurously essayed the basket in order to experience how, in practice, that means of escape felt.

The Mosel had missed her way in a dense fog. The merest quiver of the compass-card, a point south instead of west, would have kept her clear of Beast Point and the Man-of-War rocks, sent her safely into Mount's Bay, and on her course for rounding the Land's End. But it was not to be. She struck under the signal-house at seven a.m. Mr. J. N. Cox, son of the active postmaster, sitting in the signal- 
room, heard the crash and was on the cliff, under which the Mosel lay fast, in two or three minutes. In a few minutes more a telegram was in Falmouth, begging that all available help might be sent; and as fast as the alarm could be given, and the boat launched, the lifeboat crew and the coastguard from Lizard Town were on the scene of disaster.

By great good-fortune, the steam-tug Rosetta of Falmouth, on the look-out for homeward-bound vessels, was drifting close by. She heard the crash and cries for help, and, guided by the sound, found the vessel ashore. The Rosetta was alongside within ten minutes of the striking of the Mosel, and conveyed the first load of passengers to Cadgwith Cove, two miles off.

When she returned to Beast Point, all but the firstcabin passengers had been taken off in boats, and the Rosetta took on board the rest, and landed thern with the mails and specie at Falmouth. The little tug rescued in all two hundred and forty-seven of the Mosel's passengers.

The mails were sent by railway to Southampton, and again despatched thence, the day following the wreck, to New York.

The poor vessel lay for many weeks on the rocks, attempts to float her off being in vain. One day a foretaste of the equinoctial gales lifted her somewhat; she parted amidships: the stern half slipped off into deep water, and after awhile the fore part heeled over and disappeared. That was the end of the Mosel. 
Penzance in the early sixties still possessed a postmistress who, from the yet earlier twenties, assisted by postromen fully six feet high, had ruled her office with a hand of steel not always hidden by the velvet glove. Two of her rules of official life admitted of no exception. When 'Box Closed,' 'Mail not Arrived,' or 'Mail not Sorted,' was placarded on the square foot of hinged office-window, no appeal could induce her to open it, nor would she ever give change.

Once a traveller, staying at the Union Hotel close by, publicly wagered that he would break through the blockade. His plan was to knock persistently at the little window when 'Box Closed' was notified. At length, the pane of glass being reluctantly opened, he victoriously thrust in his bundle of letters, and, as he thought, won the day. But he reckoned without the postmistress; for my stout-hearted colleague, I rejoice to say, as promptly flung back his letters into the street.

The fame of this exploit being noised abroad, a certain army Colonel undertook to sap the postmistress's position on the giving-of-change question. $\mathrm{He}$ had better luck. Presenting himself at the window, he tendered a half-crown, requesting to be supplied with a shilling's worth of postage-stamps. 'I give no change,' said the lady. 'Oh, very well !' replied the Colonel.

With military strategy, he withdrew for the moment to his base of operations; then, returning armed with 
a bag of sixty pennies, tapped gently at the window, and, with polished courtesy, suavely asked for 'A penny stamp, if you please, madam.' The postmistress fixed her enemy with the glittering eye of triumph, took the penny, gave the stamp, and briskly shut the window. A minute later there was a second knock, a second inquiry for "A penny postage stamp, if you please, madam'! I know not at which pennythe third or the thirtieth-the citadel capitulated. But in the end the Colonel ungallantly won the day, and retired bearing off all the honours of war.

If the army were victorious at Penzance, the nary, on the other hand, sustained, at about the same time, a serious reverse, strange to say, in Derbyshire.

A postmistress of Buxton, in reality a woman of abounding energy on occasion, as I seem personally to recollect, had a constitutional dislike of hurry. Once, tired of waiting for a money order which had been long in course of preparation, a navy Captain testily said he would call again for it in six months' time. In half an hour he renewed his visit: 'Is that money order ready now ?' 'What money order?' inquired the lady. "The order asked for half an hour ago.' 'Oh, the six months are not yet up. It shall be ready by then,' was the answer.

In Mount's Bay, in the fifteenth century, a ship came ashore laden with foreign leather. Somehow or other, Simon Eyre, a shoemaker in Leadenhall Street, heard of it. He scraped together every available penny, walked down from London to Penzance, 
bought up the leather, or as much of it as his money would purchase, got it by some means up to London, amassed a fortune, built a public granary, became Lord Mayor, and was knighted. He erected, if not the first Leaden Hall itself, at any rate a handsome chapel near at hand, provided wedding portions for young maids, and died in 1459 . He reproduced, even if he did not anticipate, the story of Richard Whittington and his cat, and he was certainly the prototype of Sir Titus Salt, who purchased for a mere song the neglected parcel of alpaca at Liverpool, and turned it to such account that with the produce he built the model township of Saltaire and achieved more than one good end.

Penzance has a strong claim on the good-will of the miner-outside the old post-office stood, I recollect, the statue of one of her sons, a benefactor of mankind-the great Sir Humphry Davy. 


\section{[ I 43 ]}

\section{CHAPTER IX.}

BY SEVERN, TAFF, AND TOWY.

The first holiday that Lord Colchester, her Majesty's Postmaster-General, enabled a certain young clerk to take, was partly spent in what was then the little-known but picturesque seaside town of Ilfracombe. So small was this watering-place forty years ago, and so sparsely was it visited in the springtime, that the arrival of a stranger, however young and inconsiderable, fluttered the public mind.

While at Ilfracombe I received a letter in an official cover, referring, no doubt, to some merely trifling matter; but the fact of its arrival-I had been seen reading the letter, or must have dropped the cover, 'On Her Majesty's Service,' in the street-caused much speculation. The Customs or the Commissioners of Excise had evidently sent down an emissary to look after malpractices affecting the revenue. Amateur smugglers and the keepers of private stills, if any, may be supposed to have held their breath.

It was here, half a century ago (when a scare prevailed about bank-notes, because of forgeries which 
had been discovered, and every lind of paper security was looked upon askance), that a tourist with a brandnew five-pound Bank of England note in his pocket found himself literally penniless. No one would change his note, and he had no other money, so that, but for the good offices of some philanthropic individual who became aware of his hard case, he might have starved.

Five-pound notes certainly formed no part of my equipment, and gave me no trouble; on the contrary, I could have borne a heavy burden of that sort without a murmur.

From Ilfracombe-from the little harbour which lies under the Lantern Rock-I set sail for the Welsh coast, and landed at Cardiff. My recollection is of a long walk from the landing-place to a moderate-sized town, abutting on an ancient castle with a ruined wall. I strolled within the boundary to view the grounds, no one hindering.

When, many years later, I visited Cardiff again, an embattled tower guarded the castle entrance, and nothing short of artillery could have pierced the newbuilt wall. The magnificent home of the Bute family presented quite another aspect. Coal and new docks had enriched both castle and town.

There can hardly be a borough in the United Kingdom which has eclipsed, or even equalled, the vigorous growth of Cardiff. The mere village of a century ago, with its handful of inhabitants, has developed into a great town containing a hundred 
and fifty thousand souls. The postal staff, which at the time of my visit consisted of eight men and a boy, now numbers more than four hundred men, and nearly a couple of hundred boys. The coal which lies in the hills behind, and the docks which fringe the shore, are, however, more eloquent of progress than any postal facts which I can adduce.

In 'Forty Years at the Post-Office,' I am conscious of having paid less attention to the posts of South Wales than to those of the northern part of the Principality. Having now got as far as Cardiff, let me handsomely repair my fault.

That roads in South Wales were in a very bad state up to the end of the last century is of course well known. An authority* states that

' The earlier the date of the roads, the worse they were planned. This was the case throughout the kingdom. When the land was originally enclosed, the top of the hills being less fertile than the bottom, the road was generally pushed there by the landowners.'

Mr. Howells, a witness from Wales, created great amusement before a Royal Commission which examined the question of highways about a hundred years ago. When asked what he knew of the condition of the roads in Wales, he replied that there were none. 'Then how do you travel?' asked the astonished chairman of the Commission. ' In ditches at the bottom of the valleys, my lord,' was the reply.

Towards the end of the century the main roads of * Agriculture, etc., in Wales, 1801. 
South Wales had been greatly improved, and had become fit for vehicular traffic. Accordingly, in 1787, quickly following the new mail-coaches, put on the Bristol road in 1784, and on the Great North Road in 1786, the first mail passed by coach through the counties of Brecon, Carmarthen, and Pembroke, to Milford Haven.

By 1802 the principal mail-route from London to South Wales lay through Bristol, and across the Severn by ferry to Chepstow; whence it passed by way of Newport, Cardiff, Swansea, and Carmarthen, to Milford Haven, which port had therefore two services. A mail-coach with a guard ran once a day in each direction. In 1825 the pace was quickened, and the eight o'clock night mail from Lombard Street got to Swansea six or seven hours earlier.

At Milford Haven, according to a public notice, the Irish mails were 'immediately conveyed to large and commodious steamers.' The mails for Pontypridd and Merthyr Tydvil were sent up from Cardiff by mail-cart once a day, until the year 1854, although the Taff Vale Railway had been opened for passenger traffic in 1841. Colonel Maberly apparently could not come to an agreement with the railway company.

When at length terms were arranged, the Taff Vale Railway carried the mails to Merthyr Tydvil and Pontypridd, then called Newbridge. I recollect turning aside on one occasion from my official duties at Pontypridd to visit the pit, which had just been the scene of a great mining disaster, when miners 
were entombed for a week or more, and were rescued only by the gallant efforts of a party of volunteers inspired and led on by the mining inspector, Mr. Wales.

The rescuing party burrowed into a great wall of coal which shut off the sealed-up gallery from the open one, and then, breaking a small driftway through the last length, passed in restoratives to the imprisoned men, and eventually got them out alive. I visited one of the rescued in his house, and looked on a man, pale and worn, it is true, but who had been face to face with death for eight or ten days and had never lost heart.

Even if railways proper had been long delayed, it is conceivable that tram-roads on the highways would still have rendered cheap postage possible and profitable; inasmuch as a paragraph, which seemed to forecast a feasible plan, appeared in the Cardiff and Merthyr Guardian of January 14, 1839, to this effect:

'A plan is said to be in agitation to establish tram-roads by the side of turnpike-roads capable of competing with railways for all ordinary purposes, and at infinitely smaller expense as well as risk. This plan is said to be at this time in operation at Llanelly. The cost, it is said, would be $£ 1,350$ per mile. Thus tram-roads might have been made to Birmingham for $£ 146,000$, while the railroad has cost $£ 6,000,000$.'

Such a tramway was subsequently laid between Swansea and the Mumbles, and a passenger car (which I occasionally travelled by) drawn by a horse, and at one time propelled, to the best of my belief, by 
steam, passed between both places twice daily, the fare being a shilling each way.

Thus there were, before the railways came, two routes for the mails, if not three, from London into South Wales-(1) by Gloucester and Breconn ; (2) by Bristol and across the Severn from New Passage; and (3) by Faringdon and Cirencester, and over the Severn by the Old or Aust Passage.

A good deal of interest attaches to the Passages; that called New being as old as the Roman occupation of Britain, and the Old ferry being no more ancient than the seventeenth century.

Where the Bristol Channel narrows to the estuary of the Severn, the river Avon turns off due east, and makes Bristol, eight or ten miles inland, a seaport. A few miles further up the estuary, where the Severn is more than two miles wide, there are, on the Gloucestershire bank, New Passage, and on the Monmouthshire bank, Portskewet.

A mile or two further still are Aust or Old Passage on one side, and Beachley on the other; but the latter is on the point of a peninsula lying between the Severn and the Wye, and on a direct road to Chepstow. New Passage is $10 \frac{1}{2}$ miles, and Aust Passage $11 \frac{3}{4}$ miles, by road from Bristol. The branch . railway to New Passage is rather longer.

For a length of time-say from Palmer's mailcoach year up to about 1829-the New Passage route was, for the Glamorganshire mails at any rate, the better of the two, as the Aust or Old ferry was ill 
provided with suitable appliances. But in the latter year the route by the Old ferry was greatly improved, a new road being cut from Chepstow to Monmouth, and a new bridge thrown across the Wye. The route of Aust became the quickest from Bristol to Liverpool, and from Chepstow to London.

Naturally, it was of much consequence that between Liverpool and Bristol-the second and third ports in England-the course of post should be as rapid as possible; and one of the latest feats of the PostOffice, while coaches yet had their day, was to put on a fast mail between these ports viâ Aust and Chepstow.

Up to nearly the end of the twenties the main road from Bristol to the Mersey lay through Gloucester and Birmingham, the angle thus formed being considerable. But when, thanks largely to the former Duke of Beaufort, the crossing of the Severn at Old Passage was greatly facilitated, and the new road and the new bridge opened, the distance was reduced from 189 miles, viâ Birmingham and Runcorn, to $158 \frac{1}{4}$, viâ Chepstow and Woodside. From Chepstow to London, through Faringdon, Aust, and Beachley, is $127 \frac{3}{4}$ miles, and by way of Bristol and New Passage, $138 \frac{1}{4}$ miles.

From the cessation of the through coaches, on the opening of the Midland line from Gloucester to Birmingham in December, 1840, if not on the opening of the Grand Junction line in 1837, the letter-bags for Liverpool had circulated by way of 
Birmingham; but when that vast work, the Severn Tunnel, was completed, it became possible to organize a through postal service from Bristol, viâ Hereford and Shrewsbury, to Crewe, and so to Liverpool and ail parts of the North and North-West. Thus the elbow at Birmingham was avoided, and the course of post quickened.

The Severn from bank to bank, between New Passage and Portskewet, is about two and a quarter miles wide, though from pier to pier the distance is only a mile and a half. At high-water, and in the daytime, crossing by ferry-boat was all very well; at low-water, and at night, in cold stormy weather, it was, I recollect, not so pleasant. One stepped out of a railway-carriage, warmed by occupation, on to a windy platform near the water's edge, descended a kind of wet scaffolding or stairway, and got on board the ferry-boat.

If the tide were running fast, the are of a great circle had to be followed, so as to hit off the opposite landing-place to a nicety. A freshet, too, might occur in the Severn, and there was the prospect of a cold, because unoccupied, railway-carriage to get into at the other end. However, to send the mails this way saved time. A bag could be got from Bristol to Cardiff by Portskewet in two and a half hours, whereas to send it by way of Gloucester usually took about five hours.

The great tunnel follows the course of the New Passage ferry. It dips from the level of the railway 
at Pilning, about fourteen miles from Bristol and a mile from the river-bank in Gloucestershire, and, crossing the Severn with fifty feet of solid rock above the crown of the arch in the middle of the stream, comes up again in another mile of deep cutting to the South Wales line at Portskewet. So, with two miles of open work and more than two miles of tunnelling, this undertaking represents from four to five miles of expensive railway. It was commenced in 1873, and completed and opened for passenger traffic in 1887 , at a cost of about two millions sterling.

In the formation of the tunnel, a diver performed a noteworthy feat. Mr. Charles Richardson, C.E., in charge of the tunnel works, tells the story.

During the progress of the works, it became necessary to shut a door in a driftway, full of water, formed under the bed of the river. It was a quarter of a mile away from a deep shaft in which water had risen more than a hundred feet. The driftway itself was only a few feet square, and along this pitch-dark, narrow passage, hindered by timber struttings above, and by rails and rough débris on the floor below, it seemed impossible for any human being to pass and shut the door.

The diver, Lambert, was sent off. Although strange to the works, he went down the deep, waterlogged shaft without hesitation, and, in the dark, groped his way along the driftway until he got within seventy yards of the door, but could drag his air-pipe no further. He had a terrible time in getting back to 
the open air. Next a foreign diver came, with diving apparatus which dispensed with an air-pipe. But on realizing what had to be done he gave up the attempt.

The brave Lambert, nothing daunted by previous failure, borrowed the foreigner's dress, and went down a second time. But the helmet, badly fitting, pinched him under the water-pressure so cruelly as to cause insupportable pain, and force him to return almost at once. Another helmet was made. Then he went down and shut the door, and so the flood was stopped and the drift cleared.

The full fruition of this great undertaking is perhaps yet to come, but meanwhile a mail-van may pass under the estuary, direct from Penzance to Crewe, and thence to whatever destination may be required.

There is no more to be said of the Old and New Passages. The opening of the tunnel was the end of their existence. The waters of the Severn flow swiftly through the Shoots, or spread with gentle ripple evenly over the English stones, undisturbed by the ferry-boat for Portskewet; and the traveller seated on the disused pier at Beachley may gaze as wistfully as he pleases on the Gloucestershire shore, but no boat will come off to land him, as of yore, under Aust Cliff.

Twenty-five years ago I ordered a bed at the Ivy Bush, at Carmarthen, which I greatly regret that I have never yet had the chance of occupying. Business compelled me, on the day of ordering it, to go straight 
through from Cardigan to Swansea, and I have never been in the town since. The inn is old and well known-placed by Cary, in his road-book of 1798 , at the head of all the posting inns in the town. Carmarthen itself is the junction point of the roads from Gloncester viâ Brecon, and from Bristol viâ Passage, to Haverfordwest and Milford Haven. It is $232 \frac{3}{4}$ miles from Hyde Park Corner viâ Portskewet.

At the Ivy Bush, even so far back as 1822, twelve mail and post coaches stopped and made their change. It has a history, social as well as postal. Here died -not indeed where the Ivy Bush is now established, but in its old abode in King Street, not far from the post-office-Sir Richard Steele. In it was born a brave man, William Nott, son of the landlord, a contractor for conveying his Majesty's mails. He entered the army, rose high, marched on Cabul, and rescued the heroic Lady Sale.

Then he came home, was created a Knight Grand Cross of the Most Honourable Order of the Bath, received from the East India Company a pension of a thousand a year, and died at Carmarthen while yet in his prime, in 1845, sharing with the gallant Picton, who fell at Waterloo, monumental honours in his native town.

At the Ivy Bush died the Marquis of Waterford, father, I take it, of the wayward young Marquis, the report of whose youthful escapades filled many a countryside with terror when I was a child. One of two sisters became his younger lordship's Mar- 
chioness; the other, the wife of Earl Canning, who gave me my appointment.

To this inn they brought the captured leader of the French attack on Fishguard, somewhere between the outbreak of the war with France in 1793 and the Peace of Amiens in 1802. The inn has lodged Horatio, Viscount Nelson of the Nile; it has seen the Government riders go through at full gallop with express mails, changing horses on the old bridge over the fine river Towy, and off again before the bystander could realize that they had fairly drawn rein at all.

In 1821 the Ivy Bush, I gather from Mr. Spurrell,* missed its opportunity. His Majesty King George IV. passed through Carmarthen. The town forthwith lost its head. In the prevailing enthusiasm, populace and post-boys conspiring, the spent four, which had galloped up from St. Clair's Bridge, were detached at the tanhouse, and did not go on to the inn. A fresh four, evolved from no one knows where, were instantly put to, and instead of smiles and salutations being exchanged with a loyal multitude lining the Bush windows, the landlord bowing at the door and foreseeing knighthood at the King's hands, the royal chaise was spurred across the Towy and on the road to Brecon or Neath, before the fervent crowd had become well aware of the fact that the King had been in their midst. Royalty had a better chance of being seen when, in July, 1863, H.R.H. Prince Arthur slept at the Ivy Bush.

* 'Carmarthen,' etc., 1879. 
From an early period the post-office in St. Mary Street displayed its energy. It made a striking contribution to local history by handsomely setting itself on fire, April 8, 1812, and blazing with such fury (being established in a chandler's shop and aware of its capacities) and with such destruction of property that the event, and the exciting fact of gunpowder being stored next door, are a tradition in Carmarthen to this day.

When, in the forties, the District Surveyor had time to deviate from the beaten track and visit the small sub-post-offices up the valleys or on the moorland of South Wales, a rich field for revision and reproof sometimes spread itself before him. 'What are those rows of letters on your shelf?' 'Oh yes, sir! I am fery sure they are valentines-oh yes!' 'But how do you know; have you opened them?' 'Oh ye-es ; it may be five or two or maybe six I hev opened-oh yes!' 'And what are these letters in this dusty pigeon-hole, which have been here, I see, a week or more?' 'Oh yes, I hev not hed time to go with them, sir; but it is Friday, or next week, or tomorrow, I sall be sure and deliver them, sir; oh yes, it wass to-day I wass going. Oh yes!'

It is only within comparatively recent years that the free delivery of letters has been fully extended to the remoter rural districts of South Wales; so that not only was it usual for rows of letters to be exhibited in sub-offices, but they were to be seen in public-house windows, village schools, etc.; whence 
they were sent to outlying farms by common carriers and others who passed on certain days of the week.

Going back a hundred years, things were of course more primitive still. A local historian says: 'At this period an old woman brought the letters from Brecon to Merthyr Tydvil, and they were taken to the Crown Inn and placed, a dozen or less in number, on a little round table; and if anyone expected a letter, he or she would drop in and look them over.'

As to opening letters, the postmaster of a large Welsh town tells me that, many years ago of course, he witnessed the following scene at a sub-office.

A villager having entered, Mr. Jones, the subpostmaster, thus addressed him:

Mr. Jones. 'Shou'! I wass make a mistake with your money order histerday.'

Villager. 'Inteed! How wass it, Mr. Shones ?'

$M r$. Jones. 'I put it all right again, shou'. I took the letter out of the pox, and made a fresh order and put it in, and sent the letter off all right.'

Villager. 'Thank you fery kindly, Mr. Shones; yes, yes, inteed, for sure, it was fery goot of you-for sure !' [Exit Villager.]

The ex-Mayor of a Welsh town must be responsible for the following story:

In Glamorganshire an old postboy, crossing a lonesome spot with mails, was met by a thief, who presented two pistols at him and demanded the mails and bullion. The postboy cried out, 'Ton't shoot me, 
and I will give you all I haf got,' and at the same time prepared to pass over the bags.

'Put,' said the postboy, 'I wiss you would fire a pullet through my hat to help me to satisfy my master that I haf been robbed.' Bang! and through the hat went the bullet. 'Theer,' said he, holding his hat at arm's length. 'Yes, yes, that will do; it will make pelief that the pullet went almost through my head. Now, do you mind firing another through the preast of my coat?' With this, he opened his coat, and the thief fired a second time. "That iss very goot,' said the postboy, 'and they will be satisfied that I had a fery narrow escape from a pullet through the heart.'

But as the thief was walking away with the booty, the postboy seized him by the collar, and presented his own loaded pistol point blank at him, crying out, ' Giff me pack my mails, you rasskel, and your empty pist-ols, or I will plow your prains out! Yes, yes, for sure!' And so the tables were turned. It must be admitted that the robber had a simple, not to say ingenuous and trusting nature.

There is not a single Welsh postwoman remainingat any rate, not in South Wales-who still wears the tall hat. That adornment seems to be extinct. The strong shoes, short petticoat, linsey dress, crossover, and even the frilled cap, flourish yet; but the tall hat went out with the trim old orange-woman whom travellers may remember at Carmarthen Junction, on the South Wales line. Her husband was a working 
hatter, who, no doubt, bought and furbished up these articles whenever he could get them; and passengers, to whom such hats were a novelty, purchased at the junction the very last of its kind daily from off the head of his far-seeing wife.

One Welsh postwoman, however, of the tall-hat period must not be forgotten. If the pleasant town of Whitby has produced a John Percival, South Wales has not been without its Nanny Loughor. When, two years ago, John Percival, postman, put down his wallet at Whitby at the age of seventy-two, after forty-six years' service as a postman, a bag of chinking sovereigns was an earnest of local appreciation.

Mr. Percival had run his long course without being absent a single day from sickness, and without being reported for a single fault, and he had safely delivered nearly six millions of letters, and walked, in the discharge of his duty, not very far short of ninety thousand miles.

Fifty years earlier, in January, 1837, there was living at Neath, in Glamorganshire, Nanny Loughor, who had then attained the great age of ninety-one (some say ninety-two), but was as erect as a young woman of twenty. She had for forty-five years carried the post between Neath and Swansea.

In so doing, Nanny walked, it is said, more than ninety thousand miles. However, this can only be a rough estimate, and probably below the true total. For when Ann Price, postwoman between Bristol and Chewmagna, died in 1837, after twenty-eight years' 
service, she had walked with the letters an estimated distance of seventy-four thousand miles.

But whether Nanny trudged four times or five the equivalent of the earth's circumference, she accomplished a noble walk before the end. When it came, I have not been able to find out, but the last glimpse I catch is of this active soul marching down the street at Neath, carrying forty or fifty pounds' weight of coal on her head, and walking as smartly and erect as ever, as though her burden of fourscore years and ten was but a sweet-smelling posy.

As regards the performances of my feminine colleagues, I think, on the whole, that Mary Jackson, lately postroman at Bilston, carries off the palm for pedestrianism, health, and endurance. From 1819 until 1870, Nary, like Percival, never missed a day's work except on four Sundays, when delivery was experimentally suspended. I suppose a quarter of a million of miles must be the tale of Mary Jackson's walks to Ettingshall and Prince's End with the post. Weather made no difference; sickness never came near her; holidays she had none.

Mary's only comment on those who sought to relieve her of her Sunday's trudge was, I grieve to relate, that they were 'a pack of fools!' She was a thrifty soul, and charitably disposed, bequeathing at her death a good round sum of money to the Wolverhampton Hospital.

At Newport (Mon.) I used to see, when inspecting the telegraphs, the old Westgate Hotel: not the fine 
structure of recent years, but the old inn remarkable as bearing traces of the Chartist riots of 1839 in bullet-marks on its front. The so-called Chartists (a political charter of six points being the rallying cry) were assembled in the neighbouring hills, and led on to Newport in force by John Frost, who had been its Mayor and a magistrate.

The main object, of course, was, by agitation and armed force, to compel in some way acceptance of their political views; but the local object, it was firmly believed, was the capture of Newport, the breaking up of the bridge across the Usk, and the seizure of the mail-coach carrying her Majesty's mails to Birmingham. The non-arrival of the Welsh mail was to be the signal of success to confederates in Warwickshire. The rioters attacked the Westgate Inn; were fired on by the military; left several of their number dead on the ground, and fled. The mails went off as usual.

Three principal and forty minor abettors-Jack the Fifer and David the Tinker amongst the latter-were put on their trial for treason. Campbell prosecuted, Pollock defended, and Tindal sat as Chief Justice of the Commission which tried the prisoners.

Israel Firman, aged ninety-one, was amongst the witnesses for the Crown. His unearthly aspect is said to have struck fear into all beholders. Edwin Thomas, grocer, explained how the mails were conveyed from Newport to Bristol. He was a Chartist, and thus interesting; but he was not a very authori- 
tative witness on postal matters. Frost was convicted, got his sentence commuted, eventually was pardoned, and died at Stapleton, near Bristol, in 1877, aged ninety-three. No harm had been done to the mailcoach or the lines of communication. The post-office now covers the site of the little inn where this venerable demagogue was born.

There is a delightful antiquity about tolls which have been levied as a manorial perquisite from 1267. For repairing Holborn Lane, in London, etc., tolls were collected from 1346. The establishment of turnpike-gates by statutory enactment dates from 1663 . But they were introduced at a very much later date into Wales.

The Rebecca riots of 1840 had a certain bearing on postal affairs, inasmuch as, directly, they led to the abolition of turnpikes in South Wales, and, indirectly, to the gradual disturnpiling of the roads elsewhere. The Post-Office could then no longer throw in freedom from toll as an inducement to passenger conveyances to carry the mails at low rates or for nothing.

It seems hard that Sioni Scybor Fawr had to suffer the heavy punishment of transportation for life for his share in breaking up a practice which certainly bore with some severity upon a portion of the population. Unluckily for him, he was held in bad repute, and an example had to be made in vindication of the law.

But Dai y Cantwr's fate, in 1844, excited the public feeling in his favour; the onerous sentence passed 
upon him, being, it was popularly held, out of proportion to his offence, turned local condemnation into general pity. He himself bewailed his hard fate, as was natural, in soft flowing Welsh, composing in prison a lament, which $\mathrm{Mr}$. Spurrell has preserved in part, and in which occur these lines:

'Instead of liberty long captivity

Is added to my grief.

* * * * * * * *

I shall be sent from my country,

From my father's house, notwithstanding tender bringing up,

To the midst of the black hordes,

Over the sea from my fair confines.'

The Lady Godiva took 'the tax away, and built herself an everlasting name'; but the luckless Dai y Cantwr, who took away a toll, had for his reward twenty years' transportation, and so far from being a principal figure in a triumphal progress, he became, in quite another sense, Drych $i$ fyd uyf $i$ fod-a spectacle to the world. 


\section{CHAPTER X.}

VI Â ST. ALBA N S.

IF I am acquainted with one part of England better than another, it is surely the first twelve or fifteen miles of the London and Holyhead road, from the General Post-Office, or from 'where Hicks's Hall formerly stood,' to the Highstone at Hadley ('Hadley Pillar,' my predecessor, Thomas Tasker, who measured its distance from Lombard Street in 1795, and found it to be rather more than twelve and a half miles, preferred to call it), or to the site of the old turnpikegate at South Mims.

' Never more,' wrote a lively author, nearly fifty years ago-'never more, as St. Paul's clock is verging towards eight, shall we hurry down the narrow outlet of the Swan with Two Necks, Lad Lane, and secure the place of honour on the box of the Holyhead mail, for a ten miles' ride on a summer's evening. A short ride by the mail-we can only say of it as Johnson said to Boswell in a post-chaise: "Life has not many better things than this." Cautiously the skilful coachman, in his pride of 
scarlet and gold, steers his impatient leaders through the mazes that conduct to St. Martin's-le-Grand. A minute's pause at the side-entrance of the Post-Office, and the guard is then seen emerging from the lamplit passage into the brightness of the western sun, with porter after porter bearing the lexthern bags. They are rapidly stowed in the boot, amidst perfect silence. "All right" is the word, and we are briskly trotting up Aldersgate Street; and then the stories of what the road was before Mr. Telford took it in hand, and how Mr. McNeill [meaning McAdam] has laid down a mile of concrete that will never be rutty, and -but we are upon the place [Barnet] where the quarrel between York and Lancaster was fought out, and so we bid a mutual good-night.'*

The writer describes the road as it now presents itself, but in the early part of this century access to Barnet and St. Albans was gained from London by only one route - that is, through Islington and Holloway, and over the western crest of Highgate Hill, passing the old house which Cromwell is said to have occupied, and so by Sir Roger Cholmondeley's School, and the western front of the Wellington Inn, to Finchley. In 1813 a new road was cut on the eastern side of Highgate, from Whittington's almshouses on the southern slope to the eastern front of the inn at the northern foot of the hill.

By this means the terrific gradients of the old road * 'The Land We Live In.' Orr and Co., Amen Corner, circa 1850. 
(which, by the way, I have often driven over, behind a four-in-hand, even when the surface of the roadway has been dangerously smooth from frost and traffic) were largely avoided.

The first attempt at improving the road was to construct a tunnel under the summit of the slope; and the tale of the works falling in, while the workmen were absent at dinner, was still fresh in 1840 , so long did news hold good in rural parts even after the thirties.

The plan of a tunnel was abandoned in favour of a deep cutting. The great viaduct, about to be reconstructed with steel girders, which crosses this cutting and connects Highgate with Hornsey, gives an idea, by its height, of the elevated crest which had to be removed in forming the new road. In later years another road was made-much of the land alongside which is still unbuilt upon-from the Regent's Park, through the western part of Hampstead, to the Great North Road near the Torrington Arms at Finchley, with the object of shortening the journey to or from the west end of London. This forms a direct way, almost straight as a right line, from Orchard Street in Oxford Street to St. Albans.

These comparatively modern formations have obliterated every recollection of the original road of all, the road along which in all probability Edward of York and his victorious army swept triumphantly on their return to London after the event of Barnet Field, in 1471. 
That road started from Holborn, and included what was Gray's Lane, and is now Gray's Inn Road, on the way to King's Cross. Then, passing St. Pancras old church on the eastern side, it followed what I believe to have been Maiden Lane (now known as York Road) to Highgate, and went by Crouch End, Hornsey Great Park, Muswell Hill, Colney Hatch, and Fryern Barnet to Whetstone, whence it was continued by the existing road to High Barnet.

This ancient highway may easily still be traced, being for the most part, except about Fryern Barnet, a spacious, well-made thoroughfare; but in Elizabeth's time it was girth-deep in mud and full of holes, from the early autumn to the late spring months.

All who are acquainted with the St. Albans road through Barnet will call to mind the dip on Finchley Common, near Brown's Wells-a favourite rendezvous of the highwayman Dick Turpin.

A Scotchman, in the middle of the last century, had bought very cheaply a fine well-bred hack, with the intention of riding on horseback, like Lord Monboddo, all the way to Edinburgh. There was no discoverable blemish to account for the low price accepted.

All went well through Highgate and to the edge of Finchley Common, when, descending the dip, the rider observed another horseman approaching. The Scotch gentleman's horse at once sidled up to the new-comer, as though he would ride him down, and behaved in so menacing a way that the stranger promptly produced his purse. Explanations and apologies ensued. 
On ascending the opposite slope, a post-chaise drew near. Again the sidling process was gone through. Now, however, blunderbusses were thrust through the window, and threats were used that, unless the alarmed rider drew off, the inmates would fire upon him.

At Whetstone or at Barnet the Scotchman lost no time in selling his horse for the best price he could get, being careful in his next purchase to avoid a steed which gave any sign of being acquainted with the habits of knights of the road.

The vigorous overflow of the population of London, as soon as the century had turned, began rapidly to people suburban parts, and the highroads out of London lost the lonely air which hitherto had marked them.

'I went to England again on a short visit in 1829,' wrote Mr. Richard Rush, an envoy from the United States. 'I was amazed at the increase of London. . . . Finchley Common, desolate in 1819, was covered with neat cottages, even villages.'

This process went on more rapidly still after the opening of the Great Northern Railway to Highgate and Finchley; but about the fifties, when Macnamara's Royal Day Mail was the principal road conveyance to and from London and Barnet, Finchley Common, to the confines of Whetstone, had still long lines of hedges unbroken by a single house. This is not the case now.

'A few years ago,' wrote the late Louisa, Marchioness of Waterford, 'I thought I would post down 
to Tyttenhanger, in the old way. But it was a street the whole way to Barnet, and, when the people saw the white horses and postillions in blue, they came crowding round.'

North of Chipping Barnet there has been no change to speak of. On Telford's road to St. Albans the houses cease abruptly at the edge of the town. There was until lately but a solitary house-the Green Dragon Inn-between Barnet and South Mims, a distance of quite three miles.

On the York road some houses have been built, and although at night the way is solitary for the two miles which lie between Hadley Highstone and Potter's Bar school-house, yet occasional residences dot its eastern side, and cheer the wayfarer by day.

But Chipping Barnet itself has altered past recognition. Trees wave in the thoroughfares; it coquets with the electric lamp. A new town has sprung up. Gone are most of the posting-houses; the Green Man has been razed to the ground; the extensive stables which the vast traffic of the great highway in the old coaching days had called into existence can hardly be traced; the very troughs which watered the thirsty draught-horses of the numberless stage-waggons journeying along the road are there no longer. Even the cage for misdemeanants has disappeared, although the stocks survive.

After many years of depression and inactivity, a slice of good luck aroused the slumbering energies of the town: the railway was extended to its very doors; 
building ground rose to a premium; the Ravenscroft bequest of April 28, 1679, which hitherto had realized only forty pounds a year, suddenly blossomed into an annual income of fourteen hundred. On the security of this accession of wealth, twelve thousand pounds have been raised and spent on a new church, whose embattled tower may be seen from Hampstead Heath, jutting up into the sky line, and the venerable grammar-school of Queen Elizabeth's foundation has been further endowed, remodelled, and enlarged.

To lecture in this school-house, I remember, came, early in the forties, a remarkable figure-that of the intrepid missionary and traveller, Dr. Wolff. He had just returned from Bokhara, after ascertaining the tragical but heroic end of two English officers, Colonel Stothard and Captain Connolly. In penetrating the country, Wolff had disdained, perhaps from policy, all disguise, and, writes Layard in his 'Early Adventures,' 'entered the city of Bolihara, dressed in his robes as a Doctor of Divinity, and holding open in his hands a large Bible, out of which he read or chanted aloud certain passages.' Deemed to be insane, he escaped molestation.

A broad and level thoroughfare for the most part carried the stream of man and beast through the old town, though here and there it was dangerously narrow. Even now, where the High Street passes the north-eastern corner of the north aisle of the church, there are barely twenty-six feet to the wall of the opposite house. 
Still, the road was hard and sound, which was more than could be said of other parts further along. For instance, when, in 1815, the idea of sending the Holyhead mail viâ Barnet was first mooted, the road through North Wales was in so dangerous a state that an inspector of mails expressed his belief that a London coachman would sooner lose his bread than engage to drive along it.

Towards Hadley, at the site of the old Green Man hotel and posting-house, the thoroughfare widens, and from this point Telford, in the twenties, cut his new road to South Mims and St. Albans, so avoiding the circuitous and hilly road by Hadley. Henceforth, the Highstone, set up by Sir Jeremy Sambrooke in 1740 to commemorate the Battle of Barnet, did but guide the way for the mails to Alconbury Hill, Wetherby, and the North. The Liverpool mails and others took to the new cut.

The Sage of Chelsea seems to have been a trifle envious of the fame of the greatest of road-engineers. 'Telford,' said Carlyle,* who met him at dinner in 1821, 'was one of those persons to hear whom would make one admire, and wonder how they have got the name and the emolument they enjoy at present. Telford spoke of his friend the Duke-of-this, and his friend the Marquis-of-that-all honourable men.'

Telford was nearly cut off in his early prime by a singular accident. In 1788 a crack showed itself in one of the pillars of the old church of St. Chad at * 'Early Letters of Thomas Carlyle.' Macmillan, 1886. 
Shrewsbury. The vestrymen met within the church to consider the matter, and called him in for an opinion. His advice was that they should first and without loss of time move elsewhere for deliberation, as at any moment the church might fall on their heads; and that they should next lower the bells and take down the tower. However, his audience thought otherwise, and Telford left them, on which they gave orders to workmen to cut away a part of the pillar and repair it. Two mornings later, as St. Chad's clock was striking four, down came tower and bells, smashing in the nave and wrecking the church.

On March 22, 1426, the monks of St. Albans Abbey marched in solemn procession to Barnet. The peck of March dust, which blew from the east over Gladsmuir Heath and the open ground where Hadley Church now stands, plentifully besprinkled the cavalcade, yet it was a splendid sight for the villagers. At the head of the column rode the Duke of Gloucester; after him, his retinue; at his right side, perhaps princes of the Church; at his bridle hand, the secular power. Behind came the monks, chanting a service as they approached the dwellings of men, the trappings of the horse and the lance-heads of the spearmen flashing back the rays of the westering sun as it sank over the wooded ridge of Dyrham Park and Elstree in the Vale.

Nearly fifty years after Gloucester's march, with footsore devotees, dusty and wayworn, lengthening 
the rear, there swept across the same heath the forces of Edward IV., confronting those of Richard Neville, Earl of Warwick and Salisbury, marching from the North. They met on Easter Day, April 14, 1471, at Hadley, just outside Barnet. Highways, meadow-lands, the seats of the nobility, farmhouses, and modern villas have effaced all traces of the heath. But its limits and aspect may easily be surmisedsoft turf and broken ground dotted with clumps of trees stretching as far as the eye could reach. The tenacious soil of Middlesex and Herts favours the growth of the oak, and keeps a grass-grown surface fresh as a bowling-green.

Here then, for the most part level or with gentle undulations, would be an open battlefield, three miles by two. One can picture Warwick's host extended on the low crests of Dancer's Hill and Bentley Heath; its left resting on Ganwick Corner, and its right on Dyrham Park ; and Edward's force, clear of the town, its right lying on the Mount next the school-house at Hadley, and its left on the crest of Ridge Lane and the cartway leading to Barnet Gate-a clear mile between the opposing lines. Then came the battle. Before long Warwick lay dead under the trees at Hadley Highstone, and Edward's men were sabring the routed as they fled to Ridge, to Barnet, Cockfosters, and Mill Hill.

It was on Gladsmuir Heath that, as Collier states, ' the last petals of the Red Rose were scattered to the winds.' 
In the sixties I recollect striving to produce some imitation of both events. A gay cavalcade crossing Hadley Green preceded festivities in honour of the marriage of the Prince and Princess of Wales, and later on, a sham fight on the adjoining common became the Battle of Hadley. Every thoughtful arrangement that could be desired by the foe had been made by us. 'Gentlemen of the Old Guard fire first,' was the chivalric order of the day when the extreme right had been crumpled up and the centre duly broken by the advent of the Ale. The old Guard were nothing loath, either to shoot us down or drink our health. Even artillery had been in contemplation to enhance the welcome, and cavalry to the extent of four Herts Yeomen were held in reserve for the purpose of cutting up stragglers. No detail was neglected which tended to the personal comfort of those who were opposed to us. Neither Edward nor Warwick could have been more considerate.

Passing Hadley Highstone no longer, the Holyhead, Liverpool, Manchester, Carlisle, and other coaches branched off along Telford's new road, and drove to St. Albans direct. Some London mail-coacheswhether on this road or others-made very long runs without change of vehicle. For example, the same mail-coach went through to Holyhead. The Carlisle coach was changed only at Manchester, the Edinburgh at York, the Glasgow at Carlisle, and the Falmouth at Exeter; while the coaches for Liverpool, 
Leeds, Hull, and Devonport ran from end to end without change.

The cathedral city of St. Albans is nine miles from Barnet. It had not reached its present ecclesiastical dignity in the coaching days, nor when I first knew it. A cathedral in our county was a privilege which came to us only in the year 1877 ; for although Barnet has always stood in the Liberty of St. Albans, and mainly in the county of Herts, St. Albans Abbey Church did not become a cathedral nor the ancient borough the seat of a bishopric and a city until towards the close of that year.

Before Lord Grimthorpe took in hand the work of restoration, St. Albans Abbey had far advanced on the road to ruin. In 1870, while Divine service was being performed in the fabric, the clerk of the works heard mysterious sounds. They came from the sinking tower. It was shored up only in time to avert its entire destruction. Not so fortunate, I recollect, about the same period, were the Dean and Chapter of Chichester Cathedral. There, notice of an impending catastrophe was given mainly by fine powder floating in the air in the nave. The Dean, after perambulating the cathedral, deemed it right as a precaution to order the withdrawal of all employés. Next day, a tradesman of the town, looking (as he told me a few years later) at the lofty spire, had his attention diverted for a moment by a customer: when he looked again, the spire was gone!

They must for long have linown at St. Albans that 
the building was not so strong as it should be, inasmuch as in so remote a year as 1323 two immense columns on the south side fell, pulling down with them the entire wooden roof, part of the southern aisle, and much of the cloister wall.

Scarcely less vehement than the Battle of the Gauges, waged by Brunel and Stephenson fifty years ago, was the Battle of the Roofs which ensued on the proposal to replace the low-pitched roof of the abbey by one of high-pitch. In the end, the question being as it were put to the vote, the 'high-pitchers had it.'

A country's history, it has been said, may be found broadly written in sign-boards. St. Albans and Barnet being ever loyal to the throne, there was a Crown Inn in both. Herts is famous for its herds; so the Bull figures in each town. The Woolpack at Barnet, on the great road to Leeds, and at St. Albans, on that to Kendal and the North-West, symbolized a staple trade of the midland counties. The Hartshorn recalled at Barnet the glories of Enfield Chase, and at St. Albans the antlered herds of Gorhambury. The Red Lion, still to be found at both places, was, I suppose, heraldic, and had the same origin as the Green Dragon, the Blue Boar, and other strange beasts which still figured on the signboards of roadside inns in the old coaching days.

There were two other points of similarity between the towns. Both possessed a cage for the temporary incarceration of evil-doers. I recollect the position of ours, near Wood Street, Barnet. The cage at 
St. Albans, which stood near Church Street, and the Barnet cage were swept away many years ago.

The story* is told of a sturdy rogue finding, in a wayfarer whom he had attacked on the St. Albans road, a stronger man than himself, and one, too, armed with a pistol. In the result, the rogue was compelled, on pain of death, to march before his captor to the Barnet cage; where the latter, having considered what a troublesome person he had on hand, prudently bade his prisoner wait outside while he went to fetch the keys, as he carefully explained, to open the cage and lock him up. If he ever returned at all, I suspect he found reason, like Dogberry and Verges, to thank Heaven he was ' rid of a knave.'

It is recorded by Mr. Ashdown that the Birmingham Wonder coach reached St. Albans, in 1826, at 8 a.m. -in two hours from the Peacock at Islington. This was no doubt identical with the Shrewsbury Wonder, which passed through Barnet at 7.5 a.m. The Peacock is ten miles from Barnet, and the Peahen at St. Albans nine; so if a few minutes for stoppages be deducted, the speed of the coach was fully ten miles an hour. Considering the long and steep hills which occur between London and St. Albans, this was a high rate for even a day coach to maintain with an unvarying punctuality.

Amongst the mail-coaches which passed through St. Albans, the first was that despatched from Liver* ' Old Barnet,' Stevens. 
pool, July 25, 1785-the very first, in fact, of Palmer's mails to run over the Great North Road. Of course, long before 1785 other conveyancespost-coaches especially-had taken the St. Albans route.

Post-coaches, which became frequent in the twenties, must not be assumed to have had a postal flavour about them any more than post-chaises. They were merely swift forms of stage-coach-' limited coaches,' in short, drawn by four horses, furnished with coachman and guard, carrying no outside, and usually not more than four inside, passengers. Some of these post-coaches professed to run faster than the mail, which was feasible enough, with light loads and no detention for bags.

A post-coach reaching London in two days started from the Cross Keys in Dale Street, Liverpool, and went through Warrington, Macclesfield, Derby, Leicester, Northampton and St. Albans.

A few years later, when the Royal Mail-coach appeared on the scene, London was reached in twentyseven hours, from the London Tavern and Talbot Inn in Liverpool, to the famous Swan with Two Necks in Lad Lane, and this coach, for a fare of three guineas, took its passengers over the better road of Lichfield, St. Albans and Barnet.

Seeing that even when her Majesty had come to the throne, and the road was as fine as it could be made, the journey occupied twenty-one hours, this early performance of the Liverpool mail-coach was, 
as it seems to me, highly creditable. But it spent two nights on the way.

It is time, however, to refer more particularly to the port of Liverpool, the London coaches for which ran, as I have stated, viâ St. Albans. 


\section{CHAPTER XI.}

THE PORT OF LIVERPOOL.

Business took me to Liverpool for the first time in the summer of 1851-thirteen years after the last coach with the Lancashire mails had been despatched from London. The glories of the road had already been forgotten. The new excitement was to travel in a train hauled up by rope from the Lime Street Terminus to Edgehill Station, or by one which used to run down the incline by mere attraction of gravity.

Statham, the aged postmaster of the nineties, had been succeeded by the Banning family, who ruled the post-office from 1798: Thomas (Statham's assistant) until 1819, William (Thomas's son) until 1847, and Charles (brother of William), the best known of all, until 1875 .

Mail-coaches had not been established in Statham's time a day too soon. Highway robberies in North Cheshire and South Lancashire had become rife. Bags sent by the new coaches mostly escaped scotfree, because, perhaps, of the blunderbuss, yet mounted riders carrying the mails in wallet and 
saddle-bag were freely attacked. In short, the footpads, baulked in one direction, operated in another.

At five o'clock in the morning, on Thursday, September 15, 1791, the post-boy, on his way to Manchester, carrying on horseback the Liverpool bag for Rochdale, and other bags, was set upon by four men at a point about a mile from Warrington, robbed of the mails, and killed.

The active Postmaster of Warrington - William Orrett-drew up a minute description of the malefactors and spread it far and wide. One was soon secured. He wore his black hair tied, a brown coat with yellow buttons, a spotted velveret waistcoat, dark velveret breeches; his stockings were mingled blue and white cotton, and his hat had a narrow brim and high crown. He was marked out for detection. Two of the others, if not all, were eventually brought to justice. Still, robberies of the mail became so frequent in particular localities that, in the first three months of 1800 , four had been committed on one road within a distance of twelve miles. The Treasury loosened the public purse-strings, and allowed fifteen hundred pounds a year to be spent in guarding the mails at night on the principal roads.

It is a singular fact that the same period-almost the same year-which saw the birth of the great system of mail-coaches, produced the still greater discoveries (more strictly, perhaps, inventions) which were to work the downfall of Palmer's handiwork at the very zenith of its fame. While mail-coaches were 
commencing their journeys to Liverpool and elsewhere, Watt was preparing to enrol specifications for improvements in his steam-engines, and Evans of Philadelphia was breaking his heart over that grand idea of high-pressure in the application of steam to revolving machinery which, it seems probable, has alone made the non-condensing locomotive possible.

Meantime, the Liverpool mail-coaches, from the traffic point of view, were already falling behind the age. They started at both ends, from the necessity of the service, late in the day. The enterprising George Boulton, of the Golden Cross, Charing Cross, saw his opportunity. In 1807-8, he started a sixinside coach, on alternate days, at seven o'clock in the morning, sent it by Burton and Uttoxeter, and allowed it to spend but one night on the way.

The Burton road was fifteen or sixteen miles the longer, and in many parts sandy, deep, rutty, hilly, and narrow. But the sagacious Boulton-no novice as a coach-master-knew what he was about. His competition thinned the mail-coach traffic. Elated by success, he then established a four-inside coach, taking the Lichfield route, and cutting out the mail altogether.

The eighteen contractors between London and Liverpool groaned aloud; to use the phrase of my predecessor, Thomas Tasker, Boulton 'kibed their heels' -in other words, took the wind out of their sails. But their lamentations were in vain. To start early in the day was not to be thought of by the Post- 
Office. Eight p.m. from London, and even later from Liverpool, were hours of departure as immutable as the laws of the Nedes and Persians. Eight o'clock from London is still the hour of despatch; half-past ten, or, at the earliest, a quarter to it, was always the mail-coach time at Liverpool.

Eight years later matters had got worse. Again there were complaints from Lad Lane and all along the line. In 1816 there were four London and Liverpool coaches, other than the mail, running chiefly by day, and spending but one night on the road; still, the passengers by mail were two nights on the coach. Only three inside passengers were booked at Liverpool for London by the mail-coach during the whole month of June. The contractors could retrieve the lost traffic only by quickening the running and shortening the stops.

They did both, the public necessarily gaining by the competition. In 1818, long before Telford had finished his work, the down Liverpool mail ran to the Roebuck, in the High Street of Newcastle-underLyme, by six o'clock in the evening, and so made Liverpool about midnight instead of three or four o'clock in the morning.

On one occasion, when the up Liverpool mail, which passed through the Potteries, had changed horses at Monks' Heath, after leaving Congleton for Newcastle, a pack of hounds ran by in full cry. The horses which had just performed the stage, harnessed as they were, started after them, took every leap, and, 
after a two hours' run, one, if not all four of them, came in at the death. Then they were led back to the changing-place, and in due course took the down mail into Congleton the same day.

William IV.'s reign had not ended before the highways had been levelled and straightened, their surfaces made hard and smooth, and stoppages cut down to a minimum. The letters arrived in Newcastle-underLyme at half-past eleven in the forenoon; they were due in Liverpool before five in the evening.

When the post-office was in Post-Office Place, the letters of the merchants were largely distributed by means of the Alphabet, an arrangement equivalent to the private boxes of the present day. A gentleman of my acquaintance who, in the early thirties, was in the habit of accompanying his father, a merchant of Liverpool, to obtain letter's, thus describes the arrangement. At a given time after the arrival of the mailcoaches, and when the assortment of the inward mail was completed, a curtain drew up, disclosing pigeonholes arranged in alphabetical order, glazed, and secured by lock and key. The renter of a box saw at a glance whether there were letters for him or not. The fees for the use of the Alphabet were then the perquisite of the postmaster, and brought him a good two thousand a year. There were comfortable pickings in what the modestly-paid civil servant of the present day must reasonably regard as the good old times.

The fastest mail-coach working out of Liverpool 
ran $30 \frac{1}{2}$ miles to Preston. A post to Preston, viâ Ormskirk, had been established in 1757 , but of course it was not until mail-coaches had become general that this one, which in after-years became the swiftest in the country, was put on the road.

The fame of the Preston mail still survives in Ormskirk, although it merely stopped at the old George and Dragon Inn, on the Market Cross, now the site of the post-office, to pick up mails and passengers. The time allowed for the run from Ormskirk to Liverpool is said to have been 'about an hour.' As the distance is $13 \frac{1}{4}$ miles, the pace was eridently smart.

Its fame survives also in so remote a town as Bournemouth; for I met there lately a resident whose first mail-coach ride was in 1836 , by this renowned vehicle, from Clayton Square, in Liverpool, to Preston. Scott drove the coach, and four bright chestnut horses sped its course.

A story has been told of a gentleman who, in spite of warnings from the superintendent, would play tricks with a bear or other savage creature in the Zoological Gardens in London. One day some human fingers were found outside its cage. At the Liverpool post-office, in the forties, the letter-boxes for the outgoing mails were swiftly closed at the appointed moment by means of a powerful lever. One day a forefinger was found in the letter-box. Neither of the maimed persons made any complaint.

In 1831 the only trace of this port being a packet- 
station was that furnished by steamers carrying a mail to the Isle of Man thrice a week in summer and once a week in winter. The passage usually occupied from eight to ten hours. But in another ten years Samuel Cunard had appeared on the scene, and had despatched his first contract mail-packet, the Britannia, to New York. In 1851, when for the first time I stood on the landing-stage and saw his vessels lying at anchor in the Sloyne, he was in the full blast of competition with the Collins Line.

At this moment there are no ferrer than forty-six distinct lines of steamers-some under contract for a term of years, some not-conveying letter mails, or parcel mails, or both, from Liverpool to places beyond sea, there being to North America alone eight separate steam lines, the oldest of all taking its name from the late Sir Samuel Cunard, of Halifax, Nova Scotia.

Around his slender figure clusters much of Liverpool's greatness-at least, of her ascendancy as a Transatlantic mail-packet station. Nowhere is the story told with greater fulness and vigour than in the 'Life of Sir George Burns,' of the great Cunard company which, from 1840 to the present day, has sent its floating palaces weekly to the United States with unfailing punctuality, unsurpassed speed, and extraordinary immunity from accident and loss.

It was not so with the ill-starred competing line of Collins, which only lasted eight years, and sustained great losses. Its operations were naturally 
watched with intense interest on the American side. I recollect, although imperfectly, how such once was shown. The Arctic, I think it was, had sailed for New York. She did not arrive in due course, part of her machinery having failed. The Cunard boat which followed brought no tidings; even the succeeding Collins boat had not sighted the sister-ship. Anxiety for her safety rose in New York and throughout the States to fever-heat. At length, early one Sunday morning, a large steamer slowly hove in sight. She flew the Collins flag.

The battery thundered forth salutes, and as though by electric impulse divining the occasion, all the bells in New York's steeples clashed into jubilant peal; and on that Sunday morning, in the city itself and as far as the telegraph could carry the news, the safe arrival of the Arctic pointed the text of many a sermon.

I would that her subsequent history had been no more tragic; but the fate of the Arctic and Pacific, if not the Atlantic, all vessels of the same line, is a very sorrowful tale, as told in the records of marine disaster.

Too little, in my opinion, has been made of the services of Cunard as the indomitable pioneer of Transatlantic mail-packet lines, unless, indeed, the grant of a baronetcy is held to be a sufficient recognition of conspicuous merit. It is true that he did not accomplish his great work unaided. Without the organizing genius and high mercantile reputation of 
George Burns, of Glasgow, the ripe practical knowledge of David MacIver, of Liverpool, and the resources of both, his enterprise might have failed. Still, he was its central figure-a figure, by the way, which was as familiar a sight in Water Street, Halifax, as the Province Building which houses the Legislature of Nova Scotia or the old wooden church of 1750 .

For those who have visited Halifax, I may mention that Sir Samuel Cunard resided in a house in Brunswick Street, north of the Garrison Chapel, on the opposite side. The baronet's garden reached down to Water Street, where Cunard's Wharf is situated, and where the first Cunarders-Unicorn and Britannia -were docked in 1840-41. But there are no Cunards in Halifax now, although the firm of S. Cunard and Co. is still doing business at the old stand.

Until Cunard took up the Transatlantic question, the mail-service was of a very uncertain kind; in fact, passages by the largest and best vessels were often greatly prolonged, and those of vessels of the smaller class were more protracted still. The Hon. Charles Augustus Murray* relates how he sailed from Liverpool, on April 18, 1834, on board the good ship Waverley, 530 tons, bound for New York. After putting into Fayal for repairs, they anchored off Sandy Hook on July 25, three months and a week after leaving the Mersey. This, it must be owned, was a passage of phenomenal length.

* 'Travels in North America.' Richard Bentley, 1841. 
When the well-known Mr. George Ticknor,** of Boston (Mass.), paid his second visit to Europe, he reached Liverpool on June 25, 1835, after what is described as 'a prosperous voyage' of twenty-five days from New York. This was not held to be a long passage at that time.

After steam had come, the great geologist Sir Charles Lyell voyaged by the Britannia more than once. On February 1, ' in the winter of 1844,' writes Lyell - ' in the winter of 1840-41,' says Mr. Hodder - the Britannia was beset by ice at Boston. A frost of unusual intensity had caused the sea to be frozen over in the harbour, although the water is as salt there as in mid-ocean. The ice was seven feet thick at the wharf where the Britamia lay, and two feet thick at a distance of seven miles out.

Twice a day the tide, rising twelve feet, uplifted this vast sheet and let it down again; yet the surface remained even and unbroken. No sooner was it understood that the mail was imprisoned, than the public spirit of the whole city was aroused. At their sole cost (refusing a subsequent offer of repayment) the citizens cut a canal, seven miles long and 100 feet wide, through the ice; and on February 3, only two days after her appointed time, the mail-steamer, amidst the cheers of a concourse of people, passed through, and, breaking up as she went a newly-formed sheet of ice two inches thick, stood out to sea.

It may be remarked in passing that the high* 'Life of G. Ticknor.' Sampson Low, 1876. 
minded people of Boston have more than once shown that they know well the times and the seasonswhen, with stout hearts, to throw the tea overboard, and when, with strong arms and good will, to set the icebound Britisher free.

The first voyage of the Britannia from Liverpool to Boston, in 1840, was estimated to occupy fourteen and a half days, which may be taken approximately as the time likely to be required for a voyage to New York. In the early fifties the passage of the Cunard Company's boats from Liverpool to New York was twelve days and one hour. In a Parliamentary return, No. 184, of 1895, will be found records of voyages from Queenstown performed by the Cunard mail-steamers well within six days, some even within five and a half days.

For a time, about 1860, the department tried the plan of sorting at sea the American mails to and from Liverpool. The father of the service was the late Nr. George Nash, a cheerful, energetic official whom I remember very well. He lost his life in the wreck of the Hungarian on the rocky coast of Prince Edward Island.

The Americans, very justly, regarded the establishment of the British Marine Postal Service as a wonderful undertaking. In fact, we were for many years ahead of the United States in peripatetic sortation.

That great country, with all her facilities-extensive railway system, vast waterways, magnificent 
river-boats, and so on-had not a single travelling post-office, on land or water, at the time when British sea post-offices were established. But now we have given up sorting on board, while the Americans, in connection with the Germans, have recently revived the plan.

It would probably cost thirty thousand pounds a year to sort the Anglo-American mails on board the Cunard and White Star steamers-at all events this is the best estimate I can form-and if so, it is more than doubtful whether any occasional acceleration which would result could be in any sense remunerative. One may pay too much even for a good thing. The sortation resources of our large home post-offices are so great that there is little to be gained by doing the work at sea, even under the most favourable circumstances. Still, marine sorting has a shew of energy and enterprise about it which I cannot but regard with friendly interest.

'Rome,' writes a friend, 'consolidated her conquests and maintained intercourse with her colonies by constructing roads. England has done much to the same purpose by her splendid mail-packet services, that of which I write extending even to the shores of the Pacific.' Most people will agree.

If mail-coaches no longer bring mails to the Mersey, mail-ships pour in enormous masses. Liverpool is the only provincial port at which an inward mail of considerable bulk is ever sorted on the spot. Bags landed at other ports are, as a rule, sent on 
unsorted to London. Now and again the Liverpool office has to meet a heavy strain.

The inward American mail brought by the Teutonic to Liverpool, December 26, 1894, contained a hundred and twenty-five miles of letters, and nearly forty miles of books, newspapers, and other postal packets; at any rate, this is one way of putting it. Greater sobriety of language might perhaps be more acceptable to the statistician, so I will put the letters at a million and a half, and the books, etc., at three hundred thousand nearly. I will add that, if the bags had been packed in a block, it would have measured twenty-three yards in length, five in width, and two in height. Such a disposition of facts will surely meet all views.

Yet the mileage stated conveys in reality a more perfect idea of the multiplicity of thoughts expressed in written words than at first sight appears. Assuming that each letter contained at least an octavo sheet of notepaper written upon three of its four sides, the Teutonic's mail, even disregarding the books, would represent a paper band of writing, nearly two feet deep, stretching from London to Stafford. That is the sort of letter which cousins in the West exchange thrice a week with their correspondents in the old country, the process helping, no doubt, to accentuate the fact that blood is thicker than water.

These numbers and dimensions may be contrasted with those of the mail from Liverpool by the Sirius for New York in the late thirties. The latter contained 
a handful of letters, which could have been comfortably carried in the captain's pocket.

Not alone to Glasgow and Cork belong the glories of deepening a shallow channel. Liverpool has also successfully confronted the natural obstacles which threatened her anchorage, and while I saw, in the fifties, the great bar, formed by the Burbo bank off New Brighton, high and dry at low-water, there is now, I believe, never less than twenty feet of water on it, eren at the lowest tides.

But this is not all. For as long as I can remember tugs have taken off mails and passengers to the Transatlantic packets lying in the stream. Now all is changed. On June 12, 1895, the great steamship Germanic, of the White Star Line, came for the first time alongside the famous landing-stage, and within a quarter of an hour after the arrival of the special train from Euston, was on her way down the Mersey to New York.

This was on Wednesday. At two-thirty p.m. on Saturday, the 15th, the mighty Campania, of the Cunard Line, bound, like the Germanic, with the mails for New York, left her moorings in the Sloyne--the same moorings, perhaps, at which, forty-four years ago, I used to see the red funnels of the Europa, Asia, Africa, and Arabia, and others of the line, resting from their labours or preparing for fresh runs across the Atlantic. The Campania came slowly over the mile or two of water to the landing-stage-a tiny steam-tug catching at her head to steady it, as she 
swam easily across the flowing tide, just as the little stable-lad holds on to the snaffle-rein of a Derby winner coming out for a morning walk.

Drawing twenty-eight feet of water, but with half a fathom to spare under her keel, the Campania came to, at the mooring-posts, and lay alongside the Prince's stage with as little effort as an admiral's barge takes up her station by the flagship.

As she floated there, motionless and close in shore her bridge and wheel-house towered above the stagesheds, as, years ago, the bowsprit and figurehead of the old East Indiaman used to project above the roadway at Limehouse.

At 4.30 the London train rolled in to the Riverside Station, and at a quarter to five o'clock, five minutes before high-water, the ship's bell rang and the Campania sailed for New York.

After Statham's death the Banning family rose in opulence and repute. Thomas, the new postmaster, had to control a rapidly increasing postal business. His domestic concerns were not less engrossing; for, like Sherman, of the Bull and Nouth, he married in succession three wives. In the office were his sons, William and Charles, and also a connection, Joseph Banning. It was quite a family party.

When Charles came to be postmaster he was not without his trials. Under the mild rule of his father and brother, discipline within the walls of the postoffice had become more homelike than official, and 
the staff had been recruited with unsuitable people, under the bad old patronage system.

In time things righted themselves, and the Liverpool office became that model of efficiency which it is to this day.

Mr. Rich, the present incumbent, has had, in various cities, from 1842 to 1895, a far wider range than any of his predecessors. Six years a clerk and superintendent in the Bristol post-office, six years chief-clerk at Bath, ten years controller at Manchester, ten years chief-clerk at Liverpool, twenty years its postmaster, surveyor of South-west Lancashire towns, of Birkenhead and the Isle of Man, he has won his responsible position by sheer hard work, cool judgment, and tried capacity. His opinion has been sought on most practical questions of importance.

I will mention a characteristic incident. The advent of Christmas cards was very sudden in Liverpool, and altogether unexpected. One Christmas Eve-a Sunday-Mr. Rich, who was then controller, paid a visit to the post-office, and, to his surprise, found the staff overwhelmed by an avalanche of cards. It was not possible then to obtain more force. But the chief was equal to the occasion. He took off his coat, tucked up his shirt-sleeves, and set to work, an example which electrified the men, who threw such extraordinary zeal and enthusiasm into their duties that the despatch of the night mail was saved and every missive sent forward.

Mr. Rich is about to retire. Whenever he looks back 
on fifty-three years and a half of postal service, he is warranted in accounting himself, if his modesty allow, not merely the official on the active list of longest service, but the possessor of the widest knowledge of the inner working of the Post-Office of any one of its servants. Except the reduction of high rates of charge to uniform penny postage, he has seen every modern change in the mode of carrying on the business of the department, and has taken no small share in the preparations for most of them.

It startles me to think of the phases of progress which the Liverpool post-office has witnessed, even within my own experience. In 1851 I found the electric telegraph, then in the hands of a private company, established in two rooms in No. 1, North John Street, at the corner of Dale Street. There were three double-needle instruments, eight or ten clerks, and as many messengers - a score of persons all told, and the annual cost, perhaps, was a thousand pounds. There are now nearly a thousand telegraph officials, who cost more than fifty thousand pounds a year, and the number of telegraph instruments working from the chief office and the office in the Stock Exchange is nearly two hundred.

As for letters, in 1851, when I first knew Liverpool, the post-office delivered, I believe, fewer than two hundred thousand letters a week; whereas now, in 1895, I must estimate them at over thirteen hundred thousand. They absorb the services of a brigade of 
more than eleven hundred persons, about sixfold the staff of my early days.

I must not pretend to a complete insight into the whole of the improvements effected at Liverpool by the eminent public servant to whose official life I have thus briefly adverted, but I doubt if even the department know, and I am quite sure the public in Liverpool do not know, half that Mr. Rich has brought about.

The city of Liverpool has shown herself, in a hundred ways, in sympathy with every advance of science-by her University College, her electric railway, her vast new waterworks, etc. But to my mind the latest, and by far the cheapest, work is not the least interesting.

There is now a complete line of telegraphic or telephonic communication all round the Bay of Liverpool for life-boat service. Crosby and Formby 'speak' direct to Bidston, New Brighton or the Orme's Head. This is a system which I trust is the forerunner of other systems of similar completeness to be undertaken by the Post-Office around the coast. 
CHAPTER XII.

THE CITY OF MANCHESTER.

When I first visited Manchester I found the postoffice established in a large, dark, and, for postal purposes, ill-arranged building in Brown Street, which had been designed as a borough court, and not as a post-office at all. The department has had to find out for itself by painful and costly experience, that, of all the administrative mistakes which can be committed with the eyes open, occupation of an adapted building for the business of a head postoffice stands in the front rank.

However, this error has been retrieved by the erection of an imposing and spacious edifice in Spring Gardens, close at hand, which houses all branches of business except the parcel post.

Nanchester considered herself a seaport long before the Ship Canal was completed, or even planned. Intersected by three river's, not to speak of the Bridgwater and other canals, she had some claim to be styled a city of the waters.

'But,' says a comparatively modern writer, 'not- 
withstanding the vast chainwork of roads, canals, and railways connecting Manchester with Liverpool, the men of the former town have still a hankering for something more in this respect. They want to see a ship actually sail up to their town. They would have Manchester a port.'

What was a dream in 1840 has since become a solid reality. Ships do sail, or, at any rate, steam, or are towed up to Manchester, and the Ship Canal has made the inland city a real port, practicable for vessels of the largest size.

In the forties $M r$. Punch bestowed considerable attention on the administration of the Post-Office. Management at Manchester did not escape his goodtempered shafts :

' One unhappy clerk is placed to do the work of a dozen, and the exhausted official, though eager to get through the whole, frequently bursts into convulsive sobs. We are given to understand that such is the difficulty of getting money orders cashed, that there is a positive depression in the value of these documents. An order for fifteen shillings was quoted at twelve and sixpence a day or two ago.'

Looking back sixty years, I do not know where a busier mail-coach centre could be found than Manchester. Coaches were despatched in all directionsto London, Liverpool, Chester, Birmingham, Sheffield, Derby, Leeds, Halifax, York, Hull, Carlisle-there was no limit to them.

By the mail-coach road through St. Albans and Derby, Manchester is a hundred and eighty-six miles from the General Post-Office. An alternative route 
through Congleton, which is five and a half miles to the westward of the true road, used to be half a mile longer.

As a matter of fact, the first $37 \frac{1}{4}$ miles of the St. Albans road-i.e., to Hockliffe-were common to most of the coaches. Here, however, the Manchester mail turned off and made for Northampton, Leicester, and Derby, whence there is a clear course through Ashbourne, Leek, and Stockport.

By the other route coaches would hug the Liverpool road as far as Congleton, and then pass through Wilmslow. There was once hardly a choice between the two highways. But when the hills about Hockliffe were levelled, the road made of a proper width and shape, a new road cut from Stone Bridge to Wednesbury and all the hills avoided, I am not sure that Congleton was not the shorter and the quicker way.

The mail by night did the hundred and eighty-six miles to Manchester in nineteen hours ; Colonel Corbett speaks of the Telegraph covering the ground by day in eighteen hours.

The great coaching inn, recognized by De Quincey, was the Bridgwater Arms, at the corner of Market Street, next the High Street. It has long since ceased to be an inn, and its site is now covered by the premises of Messrs. Harrison, Griffin and Company, which, however, include a part of the original building. But in 1802 it was, says Mrs. Banks, 'a handsome new hotel, in front of which a semicircular 
area was railed off with wooden posts and suspended chains.'

Later on, in the thirties, the inn had H. C. Lacy for landlord, by whom it was considered, rightly enough,* ' unworthy to send a person or a parcel by a more circuitous route than can be obtained elsewhere.'

On a window-pane in one of the untouched rooms of the old hotel are the following lines scratched with a diamond, and dated 1797 :

'Adieu, ye streams, that smoothly flow;

Ye vernal airs, that gently blow;

Ye fields, by flowing spring arraid;

Ye birds, that warble in the shade.

$$
\text { * * * * * }
$$

Unhurt, from you my soul could fly,

Nor drop one tear, nor heave one sigh;

But forced from C(elia)'s charms to part,

All joy forsakes my drooping heart.'

An arched entrance, which belonged to the yard in the rear of the hotel, still exists, and the inscription on the window-pane was certainly there in June, 1895, thanks to the careful thought of the present occupants of the premises.

It is easy to recall the swirl of the four-horse mailcoach for the North or the East as it swept in on its way to or from the post-office close by, to pick up or set down passengers at the inn, the artist on the box being no more daunted by the narrow semicircular drive, and the posts and chains which limited

* 'Cotton,' H. Bannerman and Sons, 1893. 
it, than later on by the long acclivity of Shap Fell, leading towards Carlisle, or the dreary stretch of moorland on the Sheffield road.

Though, by the way, for dreariness, there was little to beat the highroad to Shap, once clear of Kendal. The hearts of the timid, going North from Manchester, must have sunk within them as they found themselves, in the darkness of a winter's night, on the rough lonesome hill two and a half miles long, leading over the Fell to the village and to Penrith; and many a passenger wished himself back in the commodious coffee-room of the Bridgwater Arms or safe in the snug shelter of the Greyhound at Shap.

It has always struck me, however, that the most trying mail-coach journey the townsfolk of Manchester had to encounter was that across the moors to Sheffield; not, of course, on account of length, but of bleakness.

After the coaching period, and when telegraphs began to cover the island, the Magnetic Telegraph Company carried a main trunk over the high ground in a direct line between Manchester and Sheffield, and the maintenance of the wires-especially in a gale of wind or during frost and snow, was ever, as I have been told, the severest duty which befell inspector or lineman.

Recently, a lady informed me that she, as a child at school at Attercliffe, had four times a year to make the journey of thirty-eight miles viâ Glossop, her father putting her into the coach at Manchester, and 
a governess meeting her at Sheffield. On returning to school after the Christmas holidays, she used to arrive stiff and numbed by being shut up for seven weary hours in a coach, without the chance of a run to stretch her legs or a eup of tea to keep up the circulation; pierced by the cold of the snow-covered upland, and sickened by the smell of the dirty straw which littered the coach-floor. Such was a young girl's experience of travelling by the mail in the times around which remoteness sheds something of a halo.

Though, for that matter, it was not schoolgirls alone who suffered. A gentleman of my acquaintance travelled up as a schoolboy from Brighton to London by coach about December 21, 1840. Dr. Blimber's young pupil rode outside. He left Brighton at nine or ten o'clock in the morning, and on arriving at the Green Man and Still in Oxford Street, soon after nightfall, was found to be unable to stir a limb from extreme cold, and had to be lifted off the coach, carried indoors, and restored with hot wine and water.

Apropos of the Sheffield mail-coach drive, I cannot forbear a reminiscence of the Postmistress of Sheffield, who gave up duty in the early seventies. Of course, the headship of the office in Miss Wreaks' time was not the great and responsible post to which it has since grown, but still it was, and always had been, an appointment of importance.

This lady was a very efficient postmistress, a good 
disciplinarian, and well able to reduce to order fractious or careless officials of the opposite sex. The old chief-clerk, full of nervous apprehension, would quake at the prospect of his chief's reproof when anything went wrong. Any promoted officer would be told she had given him her confidence-he was to 'beware not to forfeit it.'

Then, her duty done, the lady would unbend, and, departing from the use of official English, would break out into the racy Hallamshire vernacular, and invite the happy man to her parlour to eat a piece of parkin (the Yorkshire reader will own to the genuine ring of my story), and, pouring out a glass of Marsala wine, enjoin him, hospitably, to 'tak' ho'd, an' sup.'

I remember that Mr. Scudamore and I went down to Sheffield in 1858 to concert with Miss Wreaks and the Surveyor arrangements for annexing the telegraph business to her duties. But, although approaching seventy years of age, the stout heart of the postmistress did not quail before the approaching burden. What, in the event, did really disturb her was the avalanche of official papers which telegraphy hurled upon her desk. In fact, after a year or two's experience of the new work, she retired from office in 1872 , and until January 8, 1884, lived out a peaceful life at Weston Bank.

As in the case of Liverpool, its great neighbour, Manchester, on the whole, has been fortunate in its postmasters. What was written of one in ' 1772 was true of another in 1887. 
In the disused churchyard of St. Ann, in the centre of Manchester, now in part absorbed in town improvements, and in part planted and laid out as a garden, there was visible, until 1891, a memorial slab bearing the inscription :

'Here is interred John Willatt, late postmaster of this town, who departed this life July 24, 1772, aged 41 years.'

Of him it has been written that he was 'second to none in this part of the kingdom in the knowledge of his profession.'

The same words might with truth have been added to the simple memorial of John St. Lawrence Beaufort, his moder'n successor, in the beautiful cemetery of Prestwich.

My private belief is that Willatt died of pure grief. In the second decade of married life the Willatts lost two of their children, and as they entered on the next, sharp sorrow again visited the modest home. In 1772, in Nay, a third son died; in June, a daughter ; in July, the father.

Sarah, Willatt's widow, of more elastic mould, bent to the storm and survived it. She succeeded her husband in the Manchester post-office, outliving him by nearly thirty years. The history of the Willatt family is comparable, in some of its features, to that sad story told by the monument which may be seen to the west of the mail road, in Stanwix churchyard, near Carlisle.*

As for the memorial slab itself, that is hidden away * 'Life of Archbishop Tait.' Macmillan, 1891. 
beneath the flagstones which form the frontage of the shops in St. Ann's Place, and the last resting-place of this sorely-stricken postmaster now resounds with the footsteps of wayfarers who throng the thoroughfare between St. Ann's Street and King Street; so that John Willatt's sole visible memorial is the entry, No. 67, in the parchment scroll deposited in the parish chest.

In 1860 came the appointment of $\mathrm{Mr}$. Beaufort as postmaster. He had been Surveyor of the posts in those parts, and was in the flower of his age and of great capacity.

The postmastership of Manchester gave ample scope for his particular kind of administrative ability. $\mathrm{He}$ laboured assiduously for twenty-seven years, taking over the telegraphs, organizing the parcel post, building a new post-office, and extending the deliveries; though, strangely enough, he strongly opposed for many years, on the ground of public convenience, a city delivery in the evening, which is now greatly valued.

Besides the work of local organization, Mr. Beaufort took part in many departmental committees of importance, and in the general preparations for the parcel post he lent a vigorous hand. Indeed, he rendered help of an indispensable kind, in undertaking to draft sets of rules for the guidance of the several classes of officers appointed to deal with postal parcels. The result was an admirable example of compact, yet lucid, compilation.

Mr. Beaufort died at seven o'clock at night, on 
December 1, 1887, after an illness of some duration. I mention the hour because, ill as he was, he literally died in harness, signing in the afternoon, as his ultimate act of office, what is known as the Voted Service Account.

As this large-hearted man did his work to the very end of his life, so was he thoughtful for others to the end, enjoining, feeble as he was, that his chief clerk, who brought him the last official document, should be suitably refreshed before leaving the house. Of his sort are the men who build up the reputation of a department of State, their ability, their vigour and their justice inspiring respect, and their consideration for others ensuring the service of heart as well as brain.

The long train of mourners-men and women from his staff-who followed their postmaster's remains to the last resting-place attested by their emotion the regard in which he was held.

Such was one of the best officials who ever served the Post-Office, and his merits must be the excuse for dwelling on them at length.

Between the Willatt family, whose work at the post-office ended in 1793, and Mr. Beaufort, three postmasters intervened-one a bookseller, Harrop; the next a beneficed clergyman, the Rev. R. H. Whitelock, who was not only Postmaster of Manchester, but held a cure of souls at Chorlton-cumHardy, and another in Lincolnshire; and, in my time, Robert Peel Willock, a cousin of the great Minister. 
I never saw Mr. Willock myself. He was an excellent officer, if, at last, rather a choleric old gentleman. All great men have their amiable weaknesses, and one of his was a very intelligible dislike of being plagued with official papers after four o'clock, when his brougham was in waiting at the door. $\mathrm{He}$ held office for the long term of thirty-two years.

Mr. Willock driving off at four o'clock, and Mr. Beaufort signing postal papers as he drew his latest breath, were very different men; but each served the State according to his lights.

A hundred years ago the postmistress and her daughter, helped by a couple of postmen, did all the work of the Manchester office. In the current year Mr. Harley finds employment not merely for two, but for 2,222 established functionaries, besides a small army of town and suburban sub-postmasters and their assistants. So much for the effect of cotton manufacture and other forms of industry on postal developments in the great city of Manchester.

Old inhabitants, in 1840 , used to tell of the time when the coach for Liverpool-I trust not the mailstarted from Manchester at six o'clock in the morning and reached its journey's end at about the same time at night. I looked in Bradshaw lately: the nine o'clock morning train from Manchester is due in Liverpool (thirty-four miles) at nine-forty a.m., being forty minutes, instead of twelve hours, in completing the run.

The course of post was largely responsible for a 
practice which struck a writer in Blackilood's Magazine of 1839 as remarkable, viz., that Manchester dined at one o'clock. 'Thus,' wrote he, 'the very heart of the day-when the light is best and the head is clearest-is consumed at Manchester by the Dinner.'

The explanation was simple enough : first, that it was the survival of a habit which dated from a patriarchal time, when, as Dr. Aikin observed, "the manufacturer worked hard for a mere livelihood and had accumulated no capital'; secondly, that when he had become wealthy and could dine at what time he pleased, the London post came in so late in the afternoon, and went out so early next morning, that there was no alternative but to dine and rest in the middle of the day, and buckle to with correspondence until supper-time. Even at Her Majesty's Accession the down night mail came in at three p.m., and the return mail was despatched at ten o'clock next morning, so leisurely was the business of life gone through.

Postmasters, not at Manchester alone, but generally, seem to be regarded by the inquiring public as the head of a Universal Information or Agency Bureau, and are addressed on many other than postal topics. A former Postmaster of Manchester tells me that an enterprising American once wrote to him explaining how prejudicial he had found to be the alteration of the Customs duties, known as the McKinley tariff. $\mathrm{He}$ stated that it was his intention to undertake a 
lecturing tour against the tariff, and he begged the postmaster at once to supply him, for that purpose, with patterns of all sorts of Manchester goods to show around !

Amongst questions put to postmasters in their official capacity, on a multitude of subjects, only two, to the best of my knowledge, have turned upon matrimony. One was propounded, in 1890 , by an extremely deaf old lady, who had to be addressed in a very loud voice, much to the edification of a crowded public office. The point was whether the particular ceremony of marriage which her daughter had gone through was or was not legally binding.

The postmaster explained that matters of that sort had not yet been added to the business of the postoffice, and suggested a reference to the local clergyman. The old lady, however, had already consulted the reverend gentleman, who had himself adroitly advised consultation with the postmaster. Next, the name of the superintending registrar was mentioned, but he, too, had been seen on the subject.

The discussion had therefore come to a dead-lock, when a happy thought struck the appellant. She would telegraph to Mr. Gladstone, who was then in opposition in Parliament, to take the matter up and settle it. A full telegram was accordingly despatched, every needful particular being given, and an answer being prepaid. In due course a reply arrived, but only to the effect that the Right Honourable gentleman was absent abroad. This greatly exasperated 
the old lady, who loudly proclaimed her opinion that, when Mr. Gladstone went 'gallivanting about like that, he should leave someone at home to do his work.'

In the other instance, a young woman applied to be informed, at the registered letter counter at Manchester, if that was the register office. On being answered in the affirmative, she requested to be told the fee. Learning that it was only twopence, she at once desired to register, at so moderate a price, the banns of marriage between herself and her young man. Necessarily, she was referred to the public registrar of marriages.

All sorts of questioners present themselves-

'Please, sir, can you tell us when it's fireworks night at Bellevue?' politely inquired, at the public counter in Brown Street, two country cousins who had come in to Manchester to see its wonders.

I must record an extremely neat repartee. In a cathedral city, but I will not say in Manchester, resided two ladies of the same name. One was the wife of an eminent person; the other, of one not so well known. A letter arrived bearing the name common to both-Mrs. Blank-and in addition the name of the post-town. It was delivered to the less conspicuous lady. Next day the rightful owner reproached the postmaster, remarking: 'You must surely be aware that I am the Mrs. Blank.' 'Madam,' rejoined the Postmaster-General's deputy, 'I am aware of it, and I own we are to blame; but I am certain 
that no further mistake will occur if you will kindly request your correspondents to address you in future as " the Mrs. Blank.",

Another adroit reply, though, I fear, one that verged on the mutinous, occurs to me. I knew, in the past, a Surveyor, a strict disciplinarian, i who, although an excellent officer and a just man, was liable to occasional accessions of irritability. On visiting a certain office, the postmaster of which followed the profession of chemist, he rebuked the official in no measured terms. 'I am afraid, sir,' said the postmaster, 'you are not quite well to-day; pray allow me to recommend one of my patent liver pills.' The Surveyor himself related this anecdote with zest, and fully realized, and I trust benefited by, the homethrust.

Another postmaster showed considerable readiness in repartee, but that was in Ireland, where humour is proverbial.

Once, at a post-office in the West, Mr. Anthony Trollope, when Surveyor, wished, for urgent reasons, to inspect the official books on a Sunday. This being demurred to, the Surveyor, a little nettled, declared he would sit where he was until the books were brought. 'Then, sir,' said the postmaster, 'you'll just sit there till you die.' Exit Mr. Trollope.

Reference to Ireland reminds me that a long time ago seven Irish labourers, all brothers, named Doyle, used to come over year after year to harvest on Squire Vernon's estate at Hilton, near Wolverhamp- 
ton. It was the custom for some of them on Saturday to obtain money orders, which one of their number posted on the following day. One Sunday Pat, with letters for the post, came to the door of the old post-office. A passer-by, noticing the situation, courteously informed him that the post-office had been removed to new premises higher up the street. 'Oh!' said Pat, 'this is the place where I have always posted my letters.' He then broke one of the panes of glass in the window nearest the position of the old letter-box, and, having dropped his letters through the aperture, walked away contented. Messrs. Bass and Co., to whom the premises belonged, on hearing of the circumstance, good-humouredly treated the matter from the diverting point of view, mended the broken pane, and sent the letters to the post-office.

On another occasion an Irish labourer applied for a money order to the postmaster, who relates the anecdote, and who was then a young clerk. When the name of the remitter was required, the applicant gave his own name, which the clerk could not catch. 'How do you spell it?' he asked. The Irishman replied: 'Sure! and if a fine clerk like you can't spell it, how d'ye think a poor man like me can ?'

At the Yeovil office, when the notice about the purchase of Stock by Savings Bank depositors came out, an aged widow asked the postmaster for advice. She wanted to buy such 'stock'-meaning, of course, stock-in-trade-as, with fixtures, would set up her son 
in business, and she saw great advantage in the new plan-'We shall have Government security for' our goods,' said she.

The term 'stock' has puzzled more than one person in the rural districts. A postmaster told me that, on questioning a sub-postmaster on the subject, the latter said he supposed the Government must have cows and pigs, and such-like stock, for sale.

Four years ago a young man having a sum of four shillings deposited in the Post-Office Savings Bank, applied on the usual form for the conversion of his deposit into Government Stock. The minimum charge of ninepence being deducted, his investment stood at three shillings and threepence. About a fortnight afterwards he called a second time and filled up the necessary form for the sale of his Stock. Ninepence being again deducted, he was left the possessor of half a crown. He then added sixpence to that amount, and redeposited three shillings in the Savings Bank, a wiser if also a poorer man by all these transactions.

On being asked his reason for making the original purchase, the depositor explained that he had been reading an advertisement of ' a probable rise in Stock,' and he thought that he would like to try his luck. Of course, a rise in Consols, to have yielded the investor a profit of even a single penny on the sale, would have had to be as much as two and a half per cent.; whereas, in the market for Consols, a probable rise might mean one of not more than an eighth per 
cent. An advance at half per cent.-let alone five times as much-would be the cause of considerable excitement on 'Change.

But the most artless client of the Post-Office was a good woman who presented herself to a postmaster in Herts, and, paying down on the counter the modest sum of three halfpence, demanded a postal order for twenty shillings. A new light broke on the applicant when it was explained to her that payment of commission alone did not complete the transaction.

There was another postal circular, issued, I think, in Mr. Fawcett's time, describing the advantages of the Post-Office in all its branches, and a copy was delivered at every house in the kingdom. In the course of this delivery the head postman, not, however, at Manchester, but at Bilston, was asked by a collier's wife, 'What's this? Is it from the cloob?' 'No,' he replied; ' it is a circular from the PostOffice, telling you of its many advantages - cheap letters, and so on.' To which the woman answered: 'We do waïnt that; we nivver yet had a letter in our lives, and we do waänt to have one bä̈d.'

Here, by the way, once came a letter addressed :

'Mr. White,

' The Split Crow,'

which was intended for the Spread Eagle Inn. Another addressed :

'Mr. Black,

'The Bonk Hoss [Anglicè, Pit-bank Horse] with the Hovel on his back,' 
was meant for the Elephant and Castle Inn-the sign in each case, and not its legend or written description, leaving an impression on the memory.

Counter clerks at most post-offices are full of resource, and help the doubting public out of many difficulties. Several years ago two ladies of my acquaintance went to the Hampstead Green post-office to send a money order to a foreign tradesman in Oxford Street. 'What Christian name?' inquired the clerk. 'He is a Turk, and has none.' 'We must have a Christian name,' insisted the clerk. 'But you can't. His bill merely says "Kotzemolien.", 'Oh, very well; that will do: cut his name in two, and make the order payable to "Kotze Molien." , This stroke of genius settled the matter.

A lament on the decease of a Manchester man has been sung by the premier postman-poet, the late Edward Capern :

'Another hearth with vacant chair,

Another lute lies broken,

Another widow wets her hair,

And eyes the treasured token.'

Capern's subject was Dr. Mark, of 'Little Men' celebrity. The Doctor was the founder of a kind of peripatetic College of Music. He trained a number of little boys as instrumentalists, and travelled throughout Great Britain, giving concerts with them.

Other postmen than Capern have turned poets, but I know only one instance of a poet turning post- 
man.* John Critchley Prince, otherwise known as the Prince of Provincial Poets, who died in Manchester in the summer of 1866 , wrote in June, 1842, as follows from London, whither he had gone from Hyde, near Manchester :

- You will forgive me not answering your letter earlier, as I have been so unsettled. I find my earliest friends the most faithful, after all. Is it not lamentable that, after being feasted, flattered, lionized, and promise-crammed for twelve months, I am now compelled to sink down to a penny postman, at $15 \mathrm{~s}$. a week? It stings me to the quick. I go to my new appointment (at Southampton) to-morrow. I do not know how I shall like it-not very well, I am sure-though I shall be then really and truly a man of letters.'

On reaching Southampton he found that he was required to attend at five o'clock in the morning, summer and winter alike, to prepare for the first delivery of letters, and that such preparation would be varied by an occasional pull at a hand-cart, used between the post-office and the railway-station.

What Mr. Lankester, the postmaster, thought of his new postman is not known. But as for the poor poet, he soon found that his new vocation could not be endured. The hand-cart and half a crown a day indifferently replaced feasting and flattery, poetry and patronage. After a few days' experience his courage failed him; he retraced his steps to friendly Manchester, and returned to his original craft of reed-making.

In preparing for the incorporation of the telegraphs * 'Memorials of Bygone Manchester.' Procter. 
with the Post-Office in 1870 , it was important to obtain not merely a great quantity of galvanized iron wire, but wire of the best quality specially prepared for being strained on telegraph-posts. Manchester, amongst other places, stood us in good stead.

I remember, in the seventies, visiting the telegraph and other wireworks of Messrs. Richard Johnson, Son and Nephew, at Manchester, from whom large supplies of telegraph-wire were procured, and witnessing all the processes of drawing a No. 8 (Birminghamwire-gauge) galvanized iron wire.

At this length of time, my recollection may be at fault, but I am tolerably sure that I was left with the conviction that within three days of a truckload of pig-iron leaving the works of an iron-producing district - say in Yorkshire-a telegram might pass through it. To go into detail, the requisite quantity could be converted into wrought iron in Lancashire; passed through all the stages of puddling, rolling, and drawing out into a mile of wire; than galvanized, coiled, sent off by train-say to Kendal; put on telegraph-posts, and telegraphy commenced upon it in a third county-all within three days.

Marvellous as the rapidity of conversion was in the seventies, I believe it is the fact that at this date it is possible, due to improved processes, to manufacture, in Messrs. Johnson's works, iron-if already converted to bar-into a coil of No. 8 galvanized 'lilled' telegraph-wire in the short space of four hours.

Hence, in any great telegraph-work of emergency 
requiring land lines, the wire would nowadays be ready to be put in position as soon as posts could be provided, armed with insulators, and planted in the ground.

However, I am not certain that even these instances of speedy manufacture, remarkable as they are, beat the record in other branches of industry.

In 1811 a wager of a thousand guineas was laid that wool on a sheep's back in the morning should, in the form of a coat, be on a man's back by night. John Coxeter, of Newbury, Berks, was the hero. Two Southdowns were shorn, the wool spun, the yarn spooled, warped, loomed, and woven, the cloth, says Percy's 'Anecdotes,' ' burred, milled, rowed, dyed, dried, sheared, and pressed, and put into the hands of the tailors by four o'clock that afternoon, and at twenty minutes past six the coat, entirely finished, was presented by Mr. Coxeter to Sir John Throckmorton, Bart., who appeared with it before an assemblage of five thousand spectators.'

This, as stated, occurred in 1811, but in April, 1816, as though nothing of the kind had been attempted in England, Brown, of Holiday Cove, in the United States, reported as a novelty that he had accomplished the feat within twenty-four hours. He triumphantly inquired (as forty years later the same question, but on widely different grounds, was asked in the Crimea): "What will they say in England?' The reply was obvious; the work had been done, and done better and quicker, some years earlier. Then 
Bock and Company-manufacturers of Manchester, in Ontario county-tried their hand, and by means of improved machinery beat the Britisher outright. They spun the wool, wove the cloth, and made the coat, in nine hours and fifteen minutes.

However, our own Manchester can well take care of its laurels in every branch of trade. Once at a local carriage manufactory a railway waggon was constructed in the short space of twenty-four hours. It is possible for a Manchester packing-house to receive two thousand five hundred pieces of ordinary China shirtings in the afternoon, make them up, pack and deliver them in bales at a railway-station, or at the dock side of the Ship Canal, before half-past six o'clock the same evening.

The total value of the cotton manufactures produced in the United Kingdom-it might almost be said in Manchester-in a year has been put at ninetytwo millions of pounds sterling. A fifth part of the production is for home use; four-fifths go abroad.

Such are the dimensions of one branch alone of that vast trade on which the wealth and prosperity of England in the main depends. 


\section{CHAPTER XIII.}

BOUND FOR THE BORDER.

IF the reader will be pleased to plant himself at Hadley Highstone, at twenty minutes past eleven o'clock at night, he may not hear the tuneful horn, but he will certainly behold the stirring sight of a brilliantly-lighted, well-horsed, Royal Mail parcelCoach rolling swiftly along the York road, on its way to Hatfield and Bedford-the result of my very last official efforts at the Post-Office.

Sixty years ago, and two hours earlier in the evening, this is what another Royal Mail-coach, which carried the Glasgow letter-bags, did every night in the week on its way to Alconbury Hill.

'All roads lead to Rome,' and whether the coach for Scotland was despatched from Lombard Street or St. Martin's-le-Grand, and whether it travelled viâ Biggleswade or viâ Royston, it inevitably came to Alconbury Hill in about seven hours from London. Thenceforward, to Wetherby or to Tadcaster (six miles from Wetherby and nine miles from York), the road was continued through Stamford and Doncaster. 
When things finally settled down-about 1836the recognised route for the Glasgow mail from London was Alconbury Hill, Wetherby, and Carlisle, and for the Edinburgh mail, Alconbury Hill and Newcastle, viâ York.

This long hill was well known to travellers of the Edinburgh and Glasgow mails. 'Here we are,' wrote Francis, Lord Jeffrey, from Grantham, on January 31, 1831; 'to-night it snows and blows, and there is good hope of our being blocked up at Witham Corner or Alconbury Hill, or some of those lonely retreats, for a week or so, or fairly stuck in the drift.'

Jeffrey no doubt was thinking of North Witham, nearly ten miles south of Grantham, where, at the Black Bull, the first change was made on the road to London. Alconbury Hill-the coaches ran to the Wheatsheaf-was much further on, $42 \frac{1}{4}$ miles from Grantham exactly. To get there he would pass through a number of places of interest, either from quaintness of name or historical association-Ram Jam House; Burleigh House by Stamford Town; White Water Turnpike-which is not, nor do I think it ever was, a turnpike-Kate's Cabin Inn ; Norman Cross, the junction of the Lincolnshire roads; and Stilton, which has given its name to a famous cheese. It is otherwise known because of Thornhill of the Bell Inn, a noted rider, who won the Kimbolton Cup with a mare that he accidentally took on to the course after a journey of twelve miles. 
Stilton, which is seventy-five miles from London, was also a town of postal importance. From it took place a liberal distribution of mails; for although Norman (or Norman's) Cross was the actual junction with the Great North Road of the mail-road through Peterborough to Boston, Lincoln, and Hull, yet Stilton, six furlongs south, was a posting-station and Norman Cross was not.

At Alconbury Hill the Wheatsheaf stood in its own grounds, a hundred yards north of the junction of the two great roads, which, at a distance from London of sixty-five miles by way of Royston, and sixty-eight by Biggleswade, merge there into the direct mail-road to Scotland, already mentioned.

I refer to the ancient inn, not the modern one. The latter is planted at the actual junction of the roads, but the original building is recessed sixty yards from the trunk road, and separated from it by a spacious garden and coach-sweep. It is now divided into two residences, one of which is a farmhouse. Both are in private occupation. Conspicuous on the lawn of the farmer's neighbour may be seen, overgrown with ivy, the Wheatsheaf's sign.

The past yet survives vigorously at Alconbury; for its postmaster, connecting the present with a period when the Wheatsheaf was in its glory, recollects the coaches sweeping up to its cheerful door. He bears in mind, too, the beginning of the end, when Landlord Warsop retired from business on the cessation of the road-traffic, and the boy, who is now the man, 
attended the consequent sale. It is he who to-day receives his London letters, not by the rattling eoach, but in the railway bag put out at Huntingdon by the mail-train from King's Cross.

Wetherby, one hundred and ninety-four miles from London, is $202 \frac{1}{2}$ from Glasgow, but it lies nearly midway between London and Edinburgh by the Boroughbridge mail-coach road. The latter important fact left its mark-perhaps it may even yet be traceable-on the front wall of the Angel Inn-which was thought to be more exactly midway than it is-and to which the mails ran for perhaps half a century. Around it the chief postal interest of the little town gathers.

For there, when the mail-coaches were put upon the road, was established the Wetherby post-office. The legend obtains that the house is so old that, when it had to be done up, nine wall-papers were stripped off in succession. Underneath the last layer were found frescoes of unknown date.

The inn, shorn of the extensions to which a flourishing road-trade gave rise, remains very much as it appeared in the coaching days-an old, low building of two stories, with a great frontage to the road. Its stabling, now numbered with the past, took in a hundred horses.

A curious feature in the history of Wetherby is that in 1824 the whole town was sold in seventy-two lots for $£ 168,000$, and in 1878 the only purchaser of a lot then alive was the postmaster, Mr. J. Smith. 
At the Angel, passengers, at least by the down night mail, had a good time; for they not only got a plentiful dinner, but they had an hour or more to eat it in. Those by the up mail, which was due early in the morning, could only have a snack by the way, for the coach was in a hurry to get on to Ferrybridge, where a considerable halt for postal purposes was unavoidable.

That was a journey of close upon seventeen miles, which the ordinary coaches completed in a single stage. The mail, with less time to spare, divided it at Aberford, passing-between Aberford and Ferrybridge-the old Peckfield turnpike, where the Leeds and Hull mail crossed its path, and that house which is still famous in the hunting season, the Bramham Moor Inn.

So many mail-roads converged on Wetherby, or points in its immediate neighbourhood, that it was an attractive rendezvous for such knights of the road as were disposed to rob the mail. On Saturday, January 31,1819 , "the portmantua containing the bags of letters from London for Knaresborongh and Harrogate, and the bye-bags of letters from Wetherby,' was stolen from the mail-rider's horse, actually under the eyes of the officials at Wetherby post-office itself.

It was a highly creditable theft, i.e., in point of dexterity and swiftness. The mail-rider was booted and spurred; his horse stood at the office-door saddled, bridled, and loaded for the journey. The 
rider turned to put on his top-coat. When he faced about, the mail was gone!

In 1826 there was another commotion. Fletcher, the Surveyor at York, put out a public notice:

'Whereas On the Night of Sunday the 5th inst., Between the hours of Ten and Eleven o'clock Three Men attempted to stop the Armed Horse Post Rider near Spofforth, as he was conveying the Mail Bags from Wetherby to Harrogate.

- The Rider escaped with the Bags in safety. The following is a Description of the Men who made this attempt. One a Tall Man, about 5 feet 11 inches in height, wearing a long straightCut Drab Coat, Trowsers same colour, Complexion dark, about 40 years of age. Two others about 5 feet 6 inches, one in a short blue single-breasted Coat, light-coloured Stockings, and Neckcloth and Breeches, the other in a drab single-breasted Coat, Breeches, and light Stockings, both Fair Complexioned Men, and about 30 years of age.

- The same Men are supposed to have made a similar attempt on the Armed Post Rider from York, on the previous Sunday night, near Bilton church.'

It speaks volumes for the coolness and observation of the mail-rider that, in the hurry and excitement of the assault and escape, he yet had leisure to measure with his eye the height of the three highwaymen, take note of their complexion, and the tint of their stockings.

To be sure, the habit of the time, which prescribed knee-breeches for all classes, helped him in this latter respect not a little. Not long ago, I heard one lady remark of another that the latter had 'five shades of colour in her bonnet'; but I doubt if she would have been self-possessed enough to observe, on being the subject of a highway robbery, that 'one of the men 
had on stockings about five shades lighter than his drab coat.'

If Newcastle was practically the Border town for the east-coast mails to Edinburgh, Carlisle, closer still to the boundary, was even more in evidence as the distributing-point for Scotland generally.

Whether the London mail for Glasgow, avoiding Carlisle, passed through Edinburgh, as at one time, or whether Glasgow received its mail viâ Wetherby and Carlisle, as at the beginning of the Victorian era, the Border city, besides sending off mails for Dumfries, Ayr, and Portpatrick, had to provide for the transit of letters between the great Lancashire towns and Glasgow and Edinburgh.

The mail-coaches from the South for Scotland drove, on arrival at Carlisle, one day to the Bush, in English Street, and the next to the Crown and Mitre, at the head of Castle Street, scarcely a stone'sthrow from the Cathedral, and little more from the Castle.

But the traveller of the thirties would fail to recognize to-day, in the Bush-pulled down and rebuilt nearly on the same site twenty years ago-the coaching inn of his youth. The quaint features of the old time have given way before modern ideas. He would see little change in the other inn, now better known as the Coffee House, which externally, at any rate, is just as it was when the Glasgow coach-horsesbreathless with the final run from the lower level of 
the Eden-pulled up, nothing loath, at its hospitable front-door.

The mails were received and delivered now in Blackfriars Street, then in St. Cuthbert's Lane, and again in English Street, at old Post-office Court - so mobile was the department in Carlisle, when coaches carried its correspondence.

Here, in the streets of Carlisle, not far from the Cathedral, the philanthropist, George Moore-a member of the firm of Messrs. Copestake, Moore, and Company, in London-was knocked down and killed by a runaway horse. Besides doing good deeds in the world at large, Mr. Moore had helped the PostOffice in its scheme of establishing postal notes or orders, by presiding over a departmental committee on the subject, in July, 1876.

Half an hour, or even less, after the arrival of the London and Manchester coaches, away from the Bush or the Crown and Mitre went splendidly appointed four-horse coaches-travelling even faster than the London mail-for Glasgow, by Abington, and for Edinburgh, by Hawick.

From Carlisle to Glasgow there are two great highways: the direct mail road, viâ Abington, and the indirect road, thirteen miles and a half longer, which passes through Dumfries, Sanquhar, Strathaven, and Kilbride. It is $95 \frac{3}{4}$ miles from Carlisle, by Abington and Beattock, to Glasgow, i.e., $396 \frac{1}{2}$ miles, viâ Barnet, from Hicks's Hall. Two Glasgow coaches started, in the thirties, from Carlisle at the same time; but the 
swift mail went, as was natural, the shorter way. This coach, the pride of the Scots Road (if I except the Aberdeen Defiance), ran at $10 \frac{1}{2}$ miles per hour, which meant, according to an old contractor's experience, eleven miles an hour over most of the ground.

It left Carlisle so quickly after the arrival of the mail-coaches from the South, that the marvel is how the tired passengers could muster strength enough to face another hundred miles over a country parts of which lie very high, and are bleak and exposed at all times. 'Caledonia stern and wild' shows a good deal of her disposition between the English Border and Beattock Summit.

The Bush and the Crown, in the winter season certainly, offered temptations which the hungry, numbed, drowsy and unrefreshed coach-top rider would have been more than mortal to resist. A halt appealed to all.

It was naturally not unusual for passengerswhether by mail or other coach - to break their journey at the hundred-mile stages. The innkeepers viewed kindly so laudable a practice. 'Passengers,' says a Leicester notice, 'being fatigued on the road from Manchester to London, and London to Manchester, may have the privilege of stopping a day or two at Leicester.' Passengers from the Potteries to London by the Regulator were notified that they had 'the privilege of staying in Birmingham all night by booking through by this coach.'

It is a speculation, not without interest, what was 
the usual length of journey which, in mail-coach days, was made without a break. Mr. Frederic Hill, formerly Third Secretary at the Post-Office, tells how, in 1835, being in the full vigour of life, he travelled from London to Edinburgh continuously, thus spending little short of two days on the coach-top.

Mr. Nobbs, the mail-coach guard, journeyed habitually a hundred and seventy miles without stopping, and has covered as many as two hundred and eighty-six miles, through deep snow, and of course outside his coach, without a halt. I think Mr. Stanley Harris, a well-known writer on the Road, once told me that he travelled through, from Holyhead to London (two hundred and sixty-one miles), outside the mail. But I may be mistaken.

The most interesting testimony, however, which has reached me is from the Rev. Dr. Martineau, who in his ninety-first year gives me, in the following letter, an account of his own experience in this direction seventy years ago :-

' London, 'May 8, 1895.

- My present connection with the North of Scotland dates back only about eighteen years, and therefore does not run off the rails. In the twenties I went frequently single day's journeys from Norwich to London, and thence, after a pause, to Bristol; and also, from the same starting-point, across country to Stamford, on the Great North Road, and thence to York. But my only visit to Scotland was made (with my late sister Harriet) by sea to Edinburgh; and, after coaching to Perth, was continued for thirty days, and completed on foot, till, on the Border, we struck the coach-road to Newcastle-on-Tyne.

'The only longer run on the highway which I remember was 
in August, 1833, when, arriving in London from a Continental six weeks' tour, on a Thursday morning, I was bound to be in Liverpool next day. This could be accomplished only by taking the first fast coach (I think, the Telegraph) right through. By twenty-seven hours' continuous travelling I reached my destination late in the afternoon, pretty well tired of locomotion, having been on the road, since leaving Zurich, six nights out of seven.

'For many years it has been my practice to take my party right through from evening to mid-day at Ariemore, a fifteen hours' spell. But now my daughters and the doctor are peremptory in their insistency on a night's rest at Edinburgh or Perth.

' These particulars, I am well aware, have no interest in themselves, nor should I state them, were they not all that I can offer in reply to your inquiry.'

As another instance, I may add that $\mathrm{Mr}$. F. H. Maberly (the Colonel's cousin) recently informed me that he recollects going down to Exeter by the Old Traveller, one of the last long stage-coaches on the Great Western Road, in October or November, 1839. He got on the coach as an outside passenger at the Old Bell in Holborn, at about four o'clock in the afternoon, and got off it at six or seven p.m. next day, at the Royal Clarence in the Cathedral Close. He does not recall any special sense of fatigue.

The direct mail-road to Glasgow crossed many rivers: the Eden, the Eske, the Sark, the Milk, the Driff, Glengoner Water, Douglas Water, and even the noble Clyde, more than forty miles, however, from Glasgow, and its dredged and deepened reaches.

But its chief interest, in modern eyes at all events, lies in the supposed existence, at one time or other, of the blacksmith's shop at Gretna Green; in the 
Thomas Carlyle country round about Ecclefechan ; in Hamilton Palace, which adorns the Vale of Clyde; and in the ruins of Bothwell Castle, the cradle of the Douglas family :

\section{'And Bothwell's lord henceforth we own, The prop and bulwark of our throne.'}

Gretna, a village a mile on the Scottish side of the Sark, lies in Dumfriesshire, nine miles north of Carlisle. The Green is there, but its famous blacksmith is a myth; though here, as at other places on or near the border-Coldstream, for example-the layman occasionally, at sight, filled up the certificate which bound together a couple for life.

I am not sure that this proceeding bore directly on postal business; yet as, when the deed was done, the eloping couple probably wrote a letter home to say so, it must have had its influence on the revenue.

A 'single' letter from the bride to her parents at (say) Doncaster, 148 miles from Gretna, would cost tenpence halfpenny; a sprig of heather from the hillside, or a forget-me-not from a handy pool, put in a bit of paper, would be an enclosure, which doubled the charge.

A line or two from young Lochinvar to the startled and angry father might have formed a second enclosure, making the letter triple, and bringing the postage to half-a-crown. On an epistle weighing an ounce, the postman's demand at Doncaster might have been, 'Letter, three and fourpence,' as it was not the custom to prepay postage. 
Besides, the transaction, no doubt in all cases, gave rise to animated family correspondence, and unless the unpaid letters written on the subject were all rejected by the addressees, an elopement clearly brought grist to the postal mill.

The author of the Gretna method of tying the hymeneal knot is said by McCulloch to have been Paisley, a tobacconist, who began to adopt it about 1750 and died in 1814, full at least of years, and it may be of honour. At any rate, the trade was too simple-anyone could qualify for it at a moment's notice-and too profitable-two couples a day on the average eloped from England into Scotland-to be let drop. Other craftsmen than tobacconists took a lesson from the forge, and welded bonds indissoluble while life endured.

Gretna Hall-formerly known as Gretna Hotelwas the chief marrying establishment (if such a phrase will pass) when the mail-coaches ran. The coaches going to Glasgow passed it on the right-hand side, a furlong beyond the post-office.

The down-mail was due at Gretna Green about early breakfast-time, which was a convenient hour for a young couple to commence housekeeping. If they were in a hurry to return to the parental roof, the up mail was due about tea-time, and they might have a long day by the gentle ripple of the Sark, and yet be soon enough to book two 'insides' for the mailcoach to Carlisle.

Arrivals by post-chaise came in at any time; they 
were, however, the exception, whatever romance may urge, and not the rule.

It was on this road, not far from Elvanfoot Inn, that the terrible mail-coach accident occurred which Mr. Hyde relates with so much vigour and effect.* At Evan Water-which must not be mistaken for the Clyde, though both rise close together-the bridge which carried the road across it, weakened by frost and floods, gave way on the night of October 25, 1808.

The up mail fell through into the stream; three of the four horses and two outside passengers, unhappily, were killed on the spot; other passengers and the coachman and guard were seriously injured. The down mail-coach came cantering along, all unconscious of the tragedy, and was also about to topple into the chasm, when the screams of a frightened woman stopped it in time and provided means of rescue for those still in danger.

The Elvanfoot Inn, on the south side of the Clyde crossing on this road, has ceased to be an inn, and is now a shooting-lodge; the highway on which it stood was diverted about the year 1824, and with it the custom of the house. The New Crawford Inn (the first halting-place on the north side of the Clyde, three miles south of Abington, and south, too, of Glengoner Water), was well known on the road. It was opened in 1822, and it still flourishes as the Crawford (Cranstoun) Hotel, despite the cessation of the coaches.

* 'The Royal Mail,' J. Wilson Hyde. Blackwood, 1885. 
At first sight it would seem surprising that Glasgow, now so spirited a city, should at the end of the last century have put up with a five days' post to London -and that, too, a riding-post-instead of a four-horse mail, covering the ground in two or three days.

It was not that the municipality were unaware of the speed and convenience of coaches. Pagnan's 'History of Glasgow' proves the contrary by giving the text of an indenture, dated as far back as 1678 , by which William Hoom, of Edinburgh, contracted with the magistrates of Glasgow for ' a sufficient strong coach, with sex able horses, whilk coach sall contine sax persons and sall go once ilk week' between Edinburgh and Glasgow.

At least they knew what a coach was. All the same, Glasgow had to wait another hundred years, and until some small experiments had been tried with a post-coach to Carlisle, before a mail-coach was put on to London.

Even more amazing still is it that, aspiring to rival the city of Edinburgh as a centre of University teaching, and outstrip it in commercial enterprise, the Glasgow merchants should have put up with the delay of their London mail taking the circuitous route of the Scottish capital, and should have continued to do so for four years after Bristol, guided by the illustrious Palmer, had found a swift way to the Metropolis.

An impetus was needed to set public spirit in motion as regards the Post-Office. It came at last. On July 7,1788 , the first mail-coach arrived in 
Glasgow from London, a cloud of horsemen having ridden out to meet it and escort it to the post-office (as its official destination), and to the Saracen's Head for more festive purposes. Down came the course of post with London from ten days to five or six. The mail-coach ran to a time-table of sixty-six hours, or at the rate of about five and a half miles an hour.

From the low speed of the new conveyance, it may be inferred that the bad state of the roads had delayed the extension of Palmer's system to Glasgow. For it is on record that in 1739 (or, as a careful commentator of my acquaintance, on the strength of what seems to be sufficient evidence, puts it, 1783) of highway there was literally none. Travellers on horseback from Glasgow found nothing worth calling a road until they reached Grantham. They rode their horses on a narrow causeway (when they had the chance), with unmade tracks on either side. Trains of pack-horses, on passing, unceremoniously thrust them-now on to rough dry ground, but more often into sloughs, girth-deep. Poorly mounted riders fared ill.

The Glasgow Chamber of Commerce, as would be expected, have ever been alive as to the benefits accruing from an accelerated mail-service, not alone with London, but, as the great West India trade of Glasgow requires, with the port of arrival and despatch of the West India mails.

In 1819, Thomas, Earl of Chichester, and James, Marquis of Salisbury - His Majesty's Postmaster- 
General (for although there were two Ministers in charge of the Post-Office, the department was ever punctilious in using in this respect the singular number)-won their hearts by so accelerating the service as to bring in the London letters early in the morning, instead of late in the afternoon, and thus abridge the course of post with Falmouth by a day. The Postmaster of Glasgow (Dugald Bannatyne) happened also to be secretary of the Chamber of Commerce. No wonder that the Chamber declared, under seal, that these improvements 'contributed to the economy of time, the expedition of remittances, and the extension of business,' and so patted the department-Bannatyne's other master-on the back.

I am not sure that nowadays public bodies are given to thanking the Postmaster-General for his services; the rather that their energy is sometimes expended in an opposite direction. But perhaps postal benefits are more frequently conferred in the Victorian age than they were in earlier reigns, and so the novelty has worn off.

My belief is that Bannatyne did much for the community in accelerating the mails. He was still in office when the sixty-six hours by road had been brought down to forty-two. As postmaster, he could offer suggestions to the Deputy Postmaster-General at Edinburgh, and help on his views by private note to Lombard Street or St. Martin's-le-Grand; as secretary of the Chamber of Commerce, he could egg on the merchants to put pressure on the Post-Office, and, 
when their prayers were granted, write letters of grateful appreciation in their name. He, as nearly as might be, solved the insoluble; he learned to serve two masters.

Bannatyne, too, was able, because of his previous experience as a merchant, to do the department good service in buying coal for the mail-packets at Milford, Howth, and elsewhere. Between 1821 and 1831 he bought and shipped more than fifty thousand tons.

Despite civilities, the Chamber were not to be caught napping. They feared that the Post-Office, lulled into a sense of security by their compliments of 1819, might be inclined, in 1825, to do the inexcusable thing of favouring Edinburgh and forgetting Glasgow. Accordingly, a committee of merchants was chosen to watch the Post-Office arrangements for the acceleration of mail-coaches, and take care that Glasgow got its due. That there must be as early an arrival of the letters at Glasgow as at Edinburgh went without saying.

This 'was the most unkindest cut of all.' The Post-Office-which was straining every nerve to do its best for everyone-was to be watched as though it could not be trusted! It had benefited Edinburgh willingly enough, no doubt, but still in a way perforce, i.e., the London mails being due at Aberdeen too late to be useful, a quickened service to the Granite City had become indispensable, and such meant necessarily an earlier arrival in the Scottish metropolis as well as at Aberdeen. 
However, neither city had much to complain of when, some years later, the London mail-coaches got respectively to Edinburgh at two twenty-three, and to Glasgow at two o'clock in the afternoon.

A few years previously, when the Battle of Waterloc was won, the mail-coach which brought the news to Glasgow bore, it is said, a red flag on its roof, the coach-horses being adorned with laurels. 'The guard, dressed in his scarlet coat and gold ornamentals, came galloping at a thundering pace along the stones of Gallowgate, making for the post-office in East Albion Street, and sounding his bugle amidst the echoing of the streets; and when he arrived at the foot of Nelson Street, he discharged his blunderbuss in the air.'

Not many pulses but beat the quicker along Clydeside on such a day.

The mail-guard's eagerness rivalled the enthusiasm which a W'estminster reviewer of 1852 recalled 'of the crowds which, in the time of the Peninsular War, blocked up the streets of every provincial town, when day after day mail-coaches, with flags proudly flying, brought news of battles fought and won.'

In 1837, under the improvement just glanced at, a letter reached Glasgow from London in forty-two hours. But Dr. Cleland records the result of an effort of posting, which took place five years earlier, and which throws into the shade the best performance of Her Majesty's mail-coach. 
The Reform Bill of 1832, he says, passed the Lords (e.g., was read a second time, for it did not actually pass until June) at 6.35 a.m. on Saturday, April 14. Mr. Young, of the Sun newspaper, started from the Strand an hour later, in a post-chaise and four, for Glasgow, taking with him copies of the Sun, in which were twenty-two and a half columns of the debate and the figures of the division. He went, no doubt, through Barnet, changed at the Red Lion or Green Man, and reached Atkinson's, in Miller Street, Glasgow, at 7.30 p.m. on Sunday-time occupied, thirty-two hours and fifty minutes, or at the average pace of eleven miles and a quarter in the hour, including stoppages. Mr. Braid, the present postmaster, receives his London mail in ten hours and two minutes from the General Post-Office.

If the Glasgow mail-road had its points of interest and natural beauty in respect of the streams which it crossed, the road to Edinburgh might well, in modern phrase, have been dubbed the Rivers Route; for at least eight river bridges had to be crossed in the ninety-one miles between Carlisle and that city. No sooner were the leaders of the mail-coach cast loose at the Crown, than the long bridge over the broad river Eden presented itself; five or six miles further on is the river Line; in the eleven and a half miles between Longtown and Langholm the beautiful Eske runs three times under the highway; and Hawick itself, forty-three miles from Carlisle, may be said to be on the Teviot. 
A couple of miles further north another bridge carries the Edinburgh road over Ale Water, and in Selkirkshire are both the Ettrick and the Tweed. Few streams of consequence crossed the path of the coach in the last thirty miles. Inns, toll-bars, and mileposts carried the road at last to the Cross at Edinburgh, 3913 miles from Hicks's Hall in London.

Yet there were other beauties in the mail-coachman's eye than the trout and salmon streams which watered the great west-coast Edinburgh road from the Border. For the first twenty miles out of Carlisle - to Langholm, in short-the highway is, or used to be, a splendid one for quick driving; it was a road on which, if anywhere, De Quincey's stage of eleven miles in fifty minutes might be possible. But from Langholm to Mospaul, in Roxburghshire, it is hilly; and Fiddleton Hill, if driven up with a heavy load when the roads are deep, is a slope to be remembered.

Out of Carlisle ran on August 31, 1862, the very last of its mail-coaches. The North British Railway, which was slowly creeping southward, had reached Portobello, on its way to Berwick, June 22, 1846. Turning sharp to the right hand from the Berwick rail, it made a bee-line for Dalkeith and Galashiels. It was at Fushiebridge in 1847, at Bowland in 1848, and at St. Boswells in March, 1849, when, again making due south, it bethought itself of Hawick, where it arrived October 25, 1849.

This broke the back of the Carlisle-Edinburgh 
mail-coach. The glorious four-in-hand which went spanking down the street from the Bush in the old days, at ten or eleven miles an hour, now started from the White Hart and the Royal, and resolved itself into a three-horse coach as far as Langholm, where it required its fourth horse for the run to Mospaul Inn and The Tower at Hawick.

The mail-coach held a peaceful monopoly of that section of the road for twelve years, but by November, 1861, the line from Carlisle northward had been carried to a point near Scots Dyke (now called Scotchdyke) toll-bar, and on August 1, 1862, it opened into Hawick, and ran the successor of the fine old coach for ever off the road.

The Tower Inn (now hotel) is still in sound repair ; but as for Mospaul Inn-a long, long stage south of Hawick, where mercifully the horses which had just come up the hill from Langholm were led smoking to their stable, and the travellers cheered themselves with a nip of the wine of the country before making for the Teviot-as for Mospaul Inn, what is it now but a heap of ruins?

There used to be in my youth a train called the Parliamentary train on every railway, which started early in the morning on week-days, and, stopping at each station on the way, carried passengers to their destination in a not over-luxurious nor under-occupied vehicle, at the statutory charge of a penny a mile.

Since the practice has obtained of conveying third- 
class passengers at the same or a lower fare by all trains, even the swiftest expresses, the 'Parly' has fallen into abeyance.

Once, when very young indeed, I took this train, by preference, from Euston to Liverpool. My impression is that I started at six or seven o'clock in the morning, and reached my destination well before night. In 1846, at all events, the seven o'clock a.m. train from Euston for Lancaster, by which passengers ior Liverpool could travel as far as Warrington, stopped at forty-two stations up to that point, and the branch train was not due at Edgehill or Lime Street until 10.30 p.m. I had ample opportunity, even at a somewhat later date, of noticing the country by the way, and the details of even the smallest roadside stopping-places.

To this day, the quaint appearance of the little Hartford Station-a hundred and seventy miles or so from London-as designed in the days of the Grand Junction Company, is stamped on my recollection.

Between Euston Square and Carlisle are nearly ninety stations. A single stoppage is generally held to involve five minutes' delay in slowing down speed, in the actual pause, and in getting up speed again. Thus, from terminus to terminus, by the Parliamentary train, more than seven hours might by taken up in stoppages alone. Even in 1854, several years after the opening of the line throughout, the early morning train from Euston took nearly fourteen hours to get to Carlisle, stopping, not, indeed, 
ninety times, but not fewer than forty-eight times on the way.

On Sunday, September 8, 1895, an experimental train of seven vehicles covered the whole distance, without a single stoppage, in seven minutes under six hours, or in less time than in the old days stoppages alone would have absorbed.

Here is a striking contrast. Within my lifetime the transit from London to Carlisle-a distance of nearly three hundred miles-has been reduced from more than thirty-two hours by coach to less than six hours by rail.

Almost on the very day on which this railway feat was accomplished by driver Benjamin Robinson, there died Joseph Bell, the first engine-driver of all, inasmuch as he drove Stephenson's engine, the Piocket, which is now in the National Museum at South Kensington. In sixty years mail-coaches were born, attained perfection, and, alas! perished. In sixty years, Bell saw the begimning of passenger railwaytrains, and all but saw the latest marvel, viz., a speed of fifty miles an hour, maintained for six successive hours without even a solitary halt by the way. 


\section{[244]}

\section{CHAPTER XIV.}

\section{A JOURNEY DUE NORTH.}

Frox Wetherby in early days, and from York in the last period, the London Royal Mail coach found its way to Newcastle-on-Tyne. Despatched from the General Post-Office at eight o'clock at night, it was due at Nercastle, in its prime, at a little before two o'clock on the morning of the third day of its journey due North.

When I first became acquainted with Nercastle, a relic of the old mail-coaching days still spanned the Tyne. The low-level stone bridge, with its nine elliptical arches, blocked the waterway indeed, but carried the great east-coast road from York to Berwickon-Tweed out of Durham into Northumberland.

Surely there must yet be those who can recall some stages of this arduous mail-coach journey. How, going North, the bridge landed the coach at Side and Sandhill, and how, at ten minutes to two o'clock in the morning, the weary horses drew the not less weary passengers and the mail up the steep grade of one in twelve of Dean Street. 
It would be too dark, and the passengers would be too fatigued, to notice, as the coach rolled past Sand. hill, a large old-fashioned building, one of the row which fronted the river. From the westernmost window of the first-floor, according to tradition, eloped on the night of November 18, 1772, Bessy Surtees, wife next day of John Scott, afterwards the famous Baron Eldon and Lord High Chancellor of England. The house still stands, and a tablet on it commemorates this fact.

Perhaps the up journey may have had more pleasurable features. With four fresh horses from the Queen's Head, and strengthened and restored by a good supper and parting cup, the travellers started, let us suppose at nine o'clock on a warm summer's evening, down Pilgrim Street, calling at the post-office in the Arcade for the night mails.

There was a time, indeed, before 1832-before, in fact, Grainger built the Arcade-when the coach passed the old post-office in Dean Street; and inhabitants still living can recollect the bags in the small hours being raised or lowered by rope from an upper window.

Slipping smoothly across Trne Bridge, coach and horses, with their load, began the ascent southwards through Gateshead. That long climb up an average incline of one in twenty-one for two whole miles, almost to Ayton Bank, gave passengers the chance of seeing how a chosen team, drawing a wellladen coach, could trot and canter up the slope and 
carry them $8 \frac{1}{2}$ miles to Chester-le-Street (which I take to have been the first change in Durham) in something less than the hour.

The old low-level causeway no longer stays the passage of shipping up the Tyne; a hydraulic swingbridge replaces it. Not even the local mails now pass over from the Side. Such as are for Gateshead go along the modern high-level roadway, and such as are for distant towns, by the rail which is carried on that mighty structure, the High-Level Railway Bridge, twenty-seven feet overhead and one hundred and twelve above high-water in the Tyne.

The bridge was designed and carried out by those notable civil engineers, Robert Stephenson and Thomas E. Harrison. Completed and opened for traffic August 4, 1850, it cost altogether nearly half a million sterling.

Once the mail-service between London and the North was threatened with disruption. A great fire broke out at Gateshead in the course of June 24, 1866.

It originated in buildings almost immediately under, at all events in dangerous nearness to, the southern end of the High-Level Bridge. By great exertions the flames were prevented from getting hold of the structure, and, beyond some slight damage to one of the bays, no real harm was done. Mr. Harrison came down, to direct the salvage efforts, by special train from London, at a speed which was then remarkable in railway experience. 
In my lifetime the Postmasters of Newcastle have been rather numerous, Lorraine, Headlam, Pellatt, Montgomery, and Nind having been followed by $\mathrm{Mr}$. Thomas Hunter and the present incumbent, $\mathrm{Mr}$. Stevenson, sometime Her Majesty's packet-agent at the island of St. Thomas in the West Indies.

The post-office itself has declined to be always tethered to the same spot. From Dean Street it has moved to the Arcade, and thence, in 1876, to the fine new building in St. Nicholas' Square. How long it will remain there-in view of the exigencies of the letter, book, sample, and parcel posts, the savings bank, and telegraphs and telephones-the twentieth century will decide. Great extensions of the new building had been already called for and effected by 1891.

Meanwhile, the past glides into the present by imperceptible changes; the Queen's Head, on the east side of Pilgrim Street, which held on until the eighties, now no longer feasts mail-coach or mailtrain passengers, whether down or up. Altered and adapted to modern purposes, within its walls eager politicians have formed a club. The ancient and busy Turf Hotel in Collingwood Street, which received and despatched the old stage-coaches, other than the mails, has blossomed into a splendid bank. Even the rooks have taken their departure, which in early mail-coach days might have been seen in their home on the spire of the Exchange; in fact, they actually made their nest on the vane itself. Of course, with 
every shift of wind round went the nest; yet the rooks brought up their young, undismayed, and continued to do so for trelve consecutive years, until nest and vane and spire were all pulled down together.

The keep of the antique castle stands-

'Was I not yesterdaye at the Newe Castelle That stonds so fayre on Tyne?'

The Battle of Otterbourne.

In the seventies the modern time-gun, fired by a spark from the General Post-Office in London, replaced its ancient artillery. But this piece of ordnance has not been discharged for years, on account of the concussion resulting from its discharge being deemed likely to injure old property in the vicinity of the castle. A time-gun is let off daily, at one o'clock, at North Shields instead.

At one period not fewer than forty mail and other coaches were despatched daily from Newcastle.

The London night mail-coach was continued through Edinburgh to Inverness, and orer the Muir of Caithness to Thurso, 783 miles from London. From Thurso the local mails were conveyed by pairhorse conveyance, westward, to Tongue. I recollect, in a very hot summer, travelling over the meor during a heary thunderstorm, when I witnessed the phenomenon of the electric spark passing upwards from the heated surface of the ground to the cloud above-atmospheric conditions, I presume, reversing 
the usual direction of electrical discharge, i.e., from the cloud downwards.

The railway has supplanted all the coaches between London and Thurso (except the Kingussie branch coach to Fort William), but this pair-horse mail still runs. It passes, at anything but a breakneck pace, over forty-five miles of as wild a country (via Reay, Melvich and Bettyhill), as the traveller would care to see, until to his satisfaction he finds an oasis in the desert, in the shape of a post-office planted amidst the fine fishing facilities which bring trade to the postal telegraph in the smiling village of Tongue.

The Thurso ride to Tongue is not, however, the longest and loneliest that the mail-cart driver has to undertake in that remote part of Caithness.

The forty-seven miles from Lairg to Lochinvar cover a longer and more lonely road. A pair-horse mail-cart gets over it in eight hours. This road has been distinguished by mention in a recent work of fiction, not, I fear, on account of the weight of the mail-bags, but because of the wild country it passes through. Lairg is also the starting-point of two other long and dreary rides-to Scourie, forty-three miles, and to Tongue itself, thirty-seven miles.

The route of the branch cart from Lochinvar to Drumbeg ( $14 \frac{1}{4}$ miles) provides the finest and most exciting drive in the United Kingdom. Not only are there splendid views-running as the road does close to the coast-but the cart is driven for part of the distance along ledges of rock overhanging the depths 
beneath. Thus, the mail-cart driver's life, in dark and stormy weather, is not wholly free from perils of which the public hear but little.

Last winter, indeed-that is, January, 1895-told a story in these parts of something more than peril. The forty-mile mail-cart ride from Wick to Helmsdale crosses the Ord of Caithness at one point eight hundred feet above sea-level. In the deep snow one of the contractor's horses missed his footing, and the poor beast fell down the side of the Ord. On another day one of the conveyances used on this road became embedded in the snow, and there it remained from December 29, 1894, to the 11th of the following March.

Such are some of the difficulties which the servants of the public have to battle with in carrying Her Majesty's mails in the Far North.

The pride of the Scotch roads was undoubtedly the Edinburgh and Aberdeen coach, Defiance, which was to North Britain what the Telegraph and Quicksilver had been to the South. Mr. Oswald Mitchell, of Glasgow, gives its time-table-129 $\frac{1}{4}$ miles in twelve hours and ten minutes, including the crossing at Queensferry and thirty minutes for stops by the way. The finest spurts were ten miles in fifty minutes down to the feiry, $8 \frac{1}{2}$ miles in forty minutes running into Perth, and $6 \frac{1}{2}$ miles from Cupar Angus in half an hour.

Would that the Defiance could be classed as a 
mail-coach, but that is not possible! For although magnificent with coachman and guard in red coats with yellow collars, she carried, besides them, fifteen passengers-four inside and eleven outside, seventeen persons in all-instead of only seven or eight, as the mail would have done. George Stow would have been aghast at the sight of her load and her pace!

I do not think that the feat of endurance said to have been accomplished by Captain Barclay (otherwise Alladice), of Ury, in driving the mail from London to Edinburgh, close on four hundred miles, without giving up the ribands over a single stage, has ever been excelled, unless, indeed, by Sir Robert Cary in 1603.

The latter rode on horseback, as is well known, over much the same ground, carrying North the tidings of the death of Queen Elizabeth, and covering the distance in about sixty hours. The great Northern highway, or horse-road, was a mere track, full of holes, and in parts well-nigh impassable. He stopped, for any length of time, at only three places on the way, sustaining a bad fall at one of them. At the best of times, and with roads in the finest order, the mail, more than two hundred years later, took fortytwo hours to reach Edinburgh. Captain Barclay, born in 1779, was no common man. On June 1 , 1809 , being then thirty years of age, he started to walk, on Newmarket Heath, for a thousand consecutive hours, a mile in each hour. Barclay finished his task on July 12, his weight being reduced during 
this stupendous walk from thirteen stone four pounds to eleven stones. Bets amounting to a hundred thousand pounds depended on the result.

As fresh as ever, and in perfect health, the Captain, his walk ended on the 12th, started on the 17 th with his regiment on the ill-fated Walcheren Expedition, and returned in due course safe and sound. A year or two earlier he had given proof of his extraordinary physical powers by doing without sleep for two nights and three days, and in the interval walking a hundred and thirty miles, dancing at balls, shooting on grousemoors, and dining at friends' houses. He would have exactly fitted the requirements of the Post-Office at the transfer of the telegraphs in 1870, but, unhappily, he died in 185t, the very year in which the depart. ment began a new lease of vigorous life.

Barclay does not stand alone in my memory of famous sportsmen who sometimes mounted the box of the mail-coach, for besides him and the renowned rifle-shot, Captain Horatio Ross (whose son won the first Queen's Prize at Wimbledon), there was the beau-ideal of sporting men, Squire George Osbaldeston.

Sholto and Reuben Percy, in their' 'Anecdotes of Sport and Eccentricity,' published in 1826, make mention of a remarkable Osbaldeston of their time, who, turned out of doors in early manhood by his father, contrived, as an attorney's clerk, to support on sixty pounds a year a wife and several children, some couples of hounds, and two hunters, getting 
with the latter an occasional day's sport in the season. It is true, his dogs lived in the attics and his horses in the cellar, there being no sanitary inspectors in those days. House rent must have been very low, and the young squire did a good turn now and then for a brewer, a corn-chandler, and the butchers of Clare Market, and so pulled through until better times came.

However, this could not have been George, my hero of the turf, for he was left an orphan in 1793, only six years old. The Squire once rode on horseback a distance of two hundred miles in eight hours and forty-two minutes. He sat in Parliament for East Retford, and fought duels with Lord George Bentinck and the famous ex-pugilist and Member of Parliament, Gully.

'Lastly,' says a writer of the early thirties, 'Mr. Osbaldeston has made his appearance on the Heath [Nermarket], not as the Hercules of horsemen, as he proved himself in his awful match against time, but as the ormer of a string of race-horses. We had rather see the Squire with his hounds in Northamptonshire, where nothing can eclipse his fame.'

Osbaldeston's feats are set out, in more or less detail, in no fewer than nine considerable works of reference. He died in 1866.

The rattle of the pole-chains of the mail-coach is still heard in Scotland. It may be only a short career which is left to the old Fort William coach from Kingussie in the Highlands. But, meanwhile, where 


\section{ON THE TRACK OF THE MAIL-COACH}

can be found a more inspiriting road to travel on in summer behind a four-horse team? In six hours and forty minutes the mail-coach is taken over fifty miles of scenery alternating in mountain, moor, loch, and forest, which, even in the land of fascinating prospects, is exceptionally impressive. 


\section{[ 255 ]}

\section{CHAPTER X V.}

WESTWARD HO!

Whнт appearance the coast of Ireland presented when I approached it for the first time I cannot say. I was on my way to Cork to receive despatches consequent on the Trent affair, which were anxiously expected from the British Minister at Washington.

It was seven o'clock in the morning, and I had not then made the valuable discovery that a prone position in the paddle-box cabin, at right angles to the steamer's course, was the finest preventive of seasickness ; at least, I have since found it so in making for the hospitable shores of the Sister Island.

We had moored alongside the Carlisle pier, in Kingstown Harbour, before the chance of beholding the beauties of the Irish coast had accurred to me.

In later years, when the opportunity presented itself of crossing the Irish Sea, I went Westward always by the day mail-packet. Then, in fine weather, and especially in the summer time, almost invariably, when we had passed the Kish, I enjoyed the sight of the sun setting behind the Wicklow mountains. 
However, I have begun my story twenty-four years too late.

In 1837, in Ireland, as in Great Britain, coaching had reached the pitch of perfection. All recollections of the eleven years of famine, which occurred between 1724 and 1772, had passed away, and from 1782 set in a period in which Ireland, said an orator of 1800 , ' had risen in civilization, in wealth, in manufactures, in a greater proportion, and with a more rapid progress, than any other country in Europe.' Mailcoaches played a part in the upward movement.

In spite of all the prosperity of Ireland at this period, it is strange how much ignorance prevailed, in the early part of the century, about the means of communication with its shores. Miss Austen makes one of her heroines declare that the Isle of Wight is the proper place of embarkation; Niss Plumptre, who wrote a book on Ireland, on the strength of visits in 1814 and 1815, decides, on the advice of an experienced friend, to proceed (presumably from London) to Bristol, and there engage a passage on a trading-ressel to Dublin. But at Bristol no such vessel is to be found; so, on further advice, she takes the coach through Gloncester and Salop to Liverpool, and there obtains passage by the packet for a guinea.

At this epoch (1814) strange legislation affecting the Post-Office was still operative. The 13th and 14 th of Charles II., chapter 11, section 22, prohibited all English packets from taking parcels; and the 
Irish Act of the 46th of George III., chapter 87, section 6 , laid the same embargo on the Irish packets. As a consequence, parcels, unless sent in the mails at costly letter postage, which was out of the question, could only be exchanged between London and Dublin once a fortnight.

The Prince Riegent coach might take your parcel to Holyhead, but there it lay, if the Henrietta had sailed, for a fortnight. Now a package, say, of eleven pounds' weight and prepaid eighteenpence, or one weighing a pound and prepaid threepence, posted in Great Britain on Monday, is on Tuesday in Ireland, if not actually delivered at its destination.

Disasters, in the form of failure of the potato crop, famine, and pestilence, were unhappily yet to come; the population had still to fall from nearly eight millions to less than five; the Encumbered Estates Act had not been dreamt of ; and such a fact as the emigration of three and a half millions of persons in a period of forty years had presented itself to the thoughts of probably no political economist.

So, all unaware of impending misfortunes, but not free from a presentiment than an extension of the railways was inevitable and likely to extinguish their existence, the mail-coaches still gaily careered away from Dublin, and far and wide in the land, some by day, but most of them by night.

'For the information of foreigners,' says the 'Postchaise Companion,' a book, full of useful facts, which was published by the Flemings, of Dublin, at the 
beginning of the century, "it may be proper to remark that eleven Irish miles are equal to fourteen British; and one shilling and a penny Irish currency is a British shilling.' Irish miles, as far as I have trudged them, are no shorter now than when the century was young; but as for the shilling, the halcyon days are gone when it produced thirteenpence across the water. By a wise use of the parcel post from Ireland, however, more may be done with the shilling than is generally known.

In the subjoined table of mail-coach services, it must be understood that the miles stated are Irish, and not English miles:

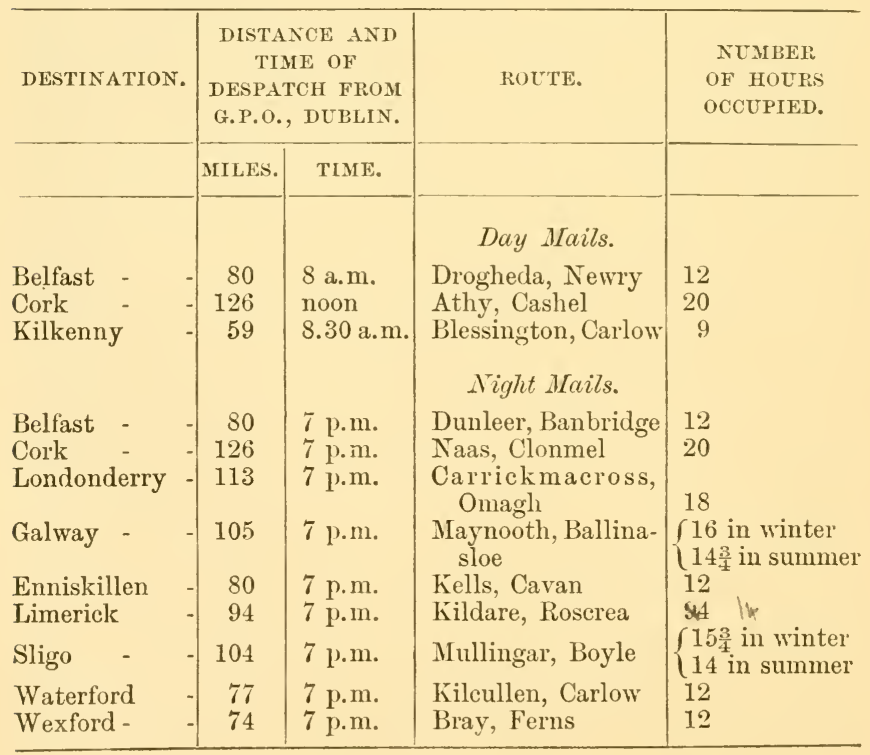


As a matter of course, all the mail-coaches, whatever the particular point of departure for passengers, called for the mails at the General Post-Office, opposite the Nelson monument-a column on which the figure of the hero, thirteen feet high, commands a full view of the Liffey from an altitude of a hundred and twenty-five feet. The building itself, which was erected from the designs of Francis Johnston, has, like Smirke's structure in St. Martin's-le-Grand, 'a fine hexastyle portico,' eighty feet broad; but, unlike the porch of the building in London, it projects over the foot pavement.

Including the mails, not fewer than fifty-seven principal coaches worked out of Dublin in 1837. Dawson Street and Upper Sackville Street were the favourite, but by no means the exclusive, points of departure. The Newry Lark, for instance, winged its flight from Bolton Street at a quarter before nine a.m., and even earlier astir than this cheerful bird was the Wonder, which started at a quarter before six from the Imperial Hotel, while the No Wonder for Armagh, not to be outdone, went off at the same time, from the same place. These were not staid mail-coaches, which disdained such tricksy titles, but private ventures.

So long as Howth was a packet-station, coaches of course ran at suitable hours swiftly along the admirable mail-road between Dublin and Howth Harbour. There was once a wonderful escape on that road. When, in 1815 , the work of constructing the harbour 
for the mail-packets was in progress, crowds of spectators used to drive down from Dublin to see what was going on. Parts of the road are flanked by precipitous descents. On a Thursday evening in June a coach, in which were four gentlemen, was shoved out of the road by a number of jaunting cars, and was ' tumbled over and over the dreadful steep opposite Lord Howth's gate,' and dashed into a thousand fragments. Happily, and I must add miraculously, the occupants escaped with a few bruises.

Belfast, like its great South-Country compeer, Cork, enjoyed a day as well as a night service by mailcoach. The night mail, in common with other coaches, left Dublin at seven p.m. ; it was at Drogheda at half-past ten; at Dundalk three minutes after one o'clock in the morning; at hill-surrounded Newry at about half-past two. It reached Belfast at seven a.m., in twelve hours from Dublin in winter, and half an hour less time in summer.

The day coach took the same route, left Dublin at eight o'clcck in the morning, and was due in Belfast (80 Irish or 102 English miles) by eight o'clock at night. The road, as are all Irish highroads, is excellent, and, except about Newry, fairly free from hills, so that the coaches easily maintained over the stages a good nine miles an hour, and, perhaps, between Drogheda and Dundalk a good ten. The Belfast Fair Trader ran as fast as the mail.

From Belfast were despatched three important cross-road mails - to Derry, 70 Irish miles, in $12 \frac{1}{2}$ 
hours; to Enniskillen, $73 \frac{1}{2}$ miles, in $13 \frac{1}{4}$ hours ; and to Larne, 18 miles, in $3 \frac{1}{4}$ hours.

Mention of the Enniskillen mail reminds me of a little anecdote. Of course, the correct phrase to denote the official emptying of a pillar-post or wallbox is 'clearance' or ' collection.' But in Bundoran, a small, pretty watering-place on the Donegal coast, which I used occasionally to visit on trips from Enniskillen to Sligo, a wholly different phrase is current. 'Is there not a letter-box along that road?' inquired a friend the other day at noon. "Tis so, your honour,' was the civil reply; ' but,' added the informant, 'it is not until eight o'clock the box will be robbed.'

It was on a journey from Belfast to Dublin, in 1812, that the elder Charles Mathews, the comedian, had a lucky escape from highway robbery. The Belfast fly in which he had taken his place carried ten inside passengers. At Drogheda, at three o'clock in the morning, Mathews left it, and procured a bed at the inn, meaning to continue his journey next day. No sooner had the fly moved on without him towards Balbriggan than highwaymen stopped it, compelled the nine passengers to alight, threatened them with instant death, and robbed them of two thousand pounds. Mathews, safe in his bed, had three hundred pounds with him, besides a quantity of stage-clothing, all of which he would have lost but for the timely sense of fatigue which caused him to rest the night at Drogheda. 
There was a great ' to do' once in a town not far from Belfast, in consequence of brevity of endorsement being carried to an extreme. A postman could not deliver the letters of a certain merchant at his private house, because the only information obtainable was that the family had gone to the seaside. 'Gone to the sea' was the postman's first idea, 'Gone to sea' his second and more compact note on the letters, which, being returned to the senders, spread consternation amongst the young merchant's friends and business correspondents.

Here, at Belfast, by the way, has Mrs. Maziere left a name behind her, not so much, perhaps, as Postmistress of Belfast, but rather as a long-lived annuitant. She received her pension for the long period of forty years-from 1795 to 1834 .

The memory reflects a stirring incident in Strabane one market-day, in January, 1843. The Sligo threehorse mail from Derry was thundering down the narrow street leading from the bridge, when inopportunely, in turning Walker's Corner, it struck a cart laden with oats in such a way that the weight of the oats shifted to the back, and in a twinkling, like Mahomet's coffin, the draught horse was seen to be dangling in mid-air.

A constable rushed forward to stay the mail. $\mathrm{He}$ laid sacrilegious hands on the coachman's whip, and bade him leave the box. Was the guard, the bold Meighan, to suffer without remonstrance this indignity to the mail? Not for a moment. He snatched a 
pistol out of the arm-chest, and prepared at once to finish off the constable on the spot.

On this the arm of the law postponed its rigours. The coach drove off jubilant towards Sligo; while the oat-cart horse was left contemplating the firmament from the altitude of a first-floor window.

In due course Meighan was haled before the magistrates. He threaten a constable? Not he, indeed! Never did milder man smile from a coach-top. The pistol was neither cocked nor presented. It was merely produced from moral motives, and quite in a Pickwickian sense-rather, indeed, as an aid to the constable in performing a difficult and delicate duty than as a hindrance. So he got off.

Cork, as will have been seen, had in 1837 the use of two Dublin mail-coaches, one starting with the day mail at noon, and the other with the night mail at seven p.m. Both took twenty hours for the journey. The route of the latter coach included the beauties of Kilkenny, once, probably still, accounted ' one of the most elegant towns or cities in the kingdom ... which has fire without smoke, earth without bog, water without mud, air without fog, and streets that are paved with marble.'

To so much perfection there was at that time but one drawback-the heavy postage to Dublin, viz., eightpence.

The day coach took the other route, and ran through Cashel, in county Tipperary, and by its famous rock. But it did so at half an hour after 
midnight, when the picturesque is not always seen to the greatest advantage.

It was Sydney Smith who said: "When the Dublin mail was stopped and robbed, my brother declares that a sweet female voice was heard behind the hedge exclaiming, "Shoot the gentleman, then, Patrick dear !", '* If this event occurred at all, it was certainly not the Cashel mail which was assailed. Michael Meagher, its guard, duly armed, would have been too strong for any reasonable display of footpads or highwaymen. This plucky official won repute by dashing in upon burglars as he came off the coach in Cashel at two o'clock on a June morning in 1835. A brother guard, Edward Ladbrook, came to the rescue, and there was a 'desperate struggle in Ryan's shop,' which ended in the capture of the thieves. Both these guards were men of the highest character, and apparently of dauntless courage.

If the mail-guards were courageous in the presence of danger, the constabulary were not less so. But for the exertions of Constable Kennedy and the police of Meelick on October 21, 1846, a sorry tale would have been told of the Limerick and Galway coach. For as it drew near the Cross of Cratloe the waters were out. Storms of rain had done great damage far and wide, and, due to the tempestuous weather which prevailed, the mail-coaches, even the mailpackets, suffered severely. The Limerick road towards Ennis was flooded for miles. A leading-

* 'A Memoir,' by Lady Holland. Longmans, 1855. 
horse got his hind-legs into a 'gripe,' or watercour'se, three feet deep. Guard Keating sprang down and saved the horse, being himself up to the waist in water. But one man, however determined, could not right the coach and relieve the passengers stuck fast in a waste of waters.

Then Kennedy from afar saw their plight, and he and his men, wading a mile, came to the rescue, and brought them safe to higher and firmer ground. ' $\mathrm{He}$ risked all to save us from our perilous situation,' reported the grateful Keating.

By means of the two mail-coaches from Dublin, (not to speak of another day coach which left at eight a.m. and ran through Clonmel in twenty-one hours and a half), Cork, with the help of four local mail-coaches, to Limerick (51 $\frac{1}{2}$ Irish miles), Waterford ( $64 \frac{1}{2}$ miles), to Bantry, Kinsale, Killarney, and Tralee, was in direct communication with Dublin and all the large towns in the South. I have driven along the great Southern coast roads-from Wexford to Youghal, and Dunmanway to Crookhaven-and have been amazed at their solidity and magnificence, despite the transfer of traffic from road to rail.

In 1835 Friedrich von Raumer, of the University of Berlin, visited the United Kingdom, and in the following year published a book of travels, mentioning a trip to Killarney, among other places. He arrived on Thursday evening, and the next day being rainy, he departed at night without seeing the lakes, the object of his visit, at all. Still, he could say with

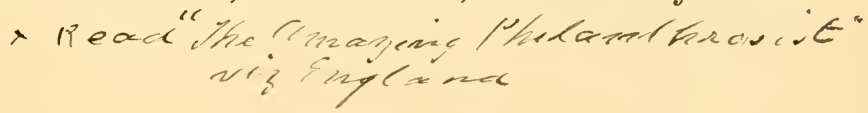


truth that he had been to Killarney, and could write a few lines on the subject.

Thirty-five years later I was at the Railway Hotel at that town, when a party of American tourists arrived, provided with alpenstocks. The next day, which was Sunday, it rained, as in Von Raumer's experience. Similarly, the party, without having stirred from the hotel, decided on a departure by the five o'clock train for Dublin, being entitled to cut 'Killarney' on their alpenstocks without having had the trouble of visiting the lakes.

Another party of tourists-not, indeed, on the same occasion-whiled away the time at Killarney by asking each other arithmetical questions, one of which, whether soluble or not, occurs to me as at least original: 'If,' said the questioner, 'three times five made eighteen, what would be four times seven?'

As to inland postage, the pendulum of change had swung freely to and fro. When the century began, the rate for a letter from Dublin to Kilkenny was only fivepence, instead of eightpence, the charge just before penny postage came in. Postages of elevenpence to Derry, fifteenpence to London, sixteenpence to Southampton, seventeenpence to Aberdeen, and so on, were supplanted by the pleasing change to the penny rate, which franked a half-ounce letter within the limits of the British Isles.

Fine as were the roads and well horsed the mails, travelling in 1836 between Cork, Limerick, and Waterford was not without its drawbacks. The bold 
peasants-their country's pride-even little children who could scarcely toddle, had contracted the playful habit of throwing stones. His Majesty's mails came in for a share of these attentions, though in a less degree than other vehicles. Still, a stone was just as hard when thrown at the Royal Mail as if aimed at the private barouche. Further, the more agile and adult were in the habit of climbing the back of the mail and hanging on to the guard's seat for miles. When forced by him to quit their hold, a cheerful volley of stones gave expression to dissent.

Sometimes an occasional shot varied the monotony of the road. On these pleasantries becoming known, there were not wanting impetuous spirits who saw in the attacks a lawlessness to be put down by force. But cooler heads viewed them in a different light, and wiser counsels prevailed. In stones, and even in occasional shots, they recognised rather the signs of a frolicsome spirit than any overt act of hostility.

As for the irregular practice of young men climbing up behind the coach, the sagacious Secretary of the Post-Office in Dublin, Augustus Godby, hit on a happy plan. All the guard had to do, he said, was to lean over from his perch, lift the culprit's cap, and fling it far back on the road. Then the hanger-on was bound to quit his hold to pick up the unconsidered trifle.

If Cork and Queenstown are entirely different places, being eight or ten miles apart, yet in all accounts of the Irish mail-service the city and the 
town ought to be taken together. It is only six and a half miles from Cork to Passage West, but then there is the ferry to cross, and it is as much as eleven and a quarter by railway throughout, because of the angle formed by the branch line from Queenstown Junction. Cork, as the capital of the South, and Queenstown, its lovely suburb and largely its port, are inseparable. I write this not ignoring the fact that by a recent deepening of the channel very large vessels can now come up to Cork itself. But it was not so in the fifties.

I have only seen the Cove, or harbour, of Cork thrice. Cove, by the way, was the name of Queenstown before Her Majesty landed there in 1849, when it ceased to be used. Once I visited Queenstown to receive the Trent's mails, in 1861 ; again about 1870 , when I travelled by special train all over the Great Southern and Western Railway, to arrange telegraphic matters; and a third time in the following year, to negotiate with the late Lord Fermoy, at Trabolgan, the terms for acquiring the telegraph to Roche's Point.

On each occasion the beauty of Queenstown and its harbour left an indelible impression on my mind, even though that effect was qualified, on the last visit, by the imminence of an upset in a sailing-boat, due to a sudden squall of wind in crossing the great harbour.

Having said as much, I shall venture-though descriptions of scenery are far from my purpose-to 
reproduce a few lines written by Mrs. Blake, of Boston, Massachusetts,* who says of the Cove of Cork :

'The hitherto unknown loveliness of the soft green upon the hills, the vivid masses of golden yellow gorse, shining like decorations upon the brow of height and headland, the soft languor of the warm air, the picturesque lines of gray houses rising from or nestling amid the green slopes, the imposing situation of the fine buildings around which the town [Queenstown] is grouped, the massive earthworks and embrasures of the two outlying forts, and the general air of cheerfulness and bright expectancy, would force the spirit of the least imaginative into sympathy.'

I now take breath to say that surely this glowing paragraph justifies my passing comment.

Queenstown itself is on an island-Great Island (seven miles by four), as distinguished from Little Island, which lies higher up the lough. It faces, at a distance of three or four miles (with Spike Island and the naval establishment of Haulbowline in between), the comparatively narrow entrance of the harbour, where Roche's Point on the east, and Church Bay on the south-west, open out into the Atlantic Ocean.

It is to the ci-devant Inman Line--now carrying the United States mail-that belongs the distinction of first calling at Queenstown, in 1856, to land and embark despatches; but it was not until 1860 that the practice was firmly established by the Cunard mail-packets making the Cove a regular port of call.

Part of my business was then to edit, as it were, what was called the Queenstown Landing-table-a * 'A Summer Holiday in Europe,' 1890. 
more difficult guide, perhaps, to act upon when the mails had to be taken by water from the mail-steamer, lying outside, right up Lough Mahon, to Cork, than now, when they are put ashore, subject to varying circumstances, at the deep-water quay in front of Queenstown railway-station. The key of the situation was the time of despatching the mail-steamers for Holyhead from Kingstown. If the steamer arrived off the Cove or came inside it in time to catch the ordinary mail-train from Cork to Dublin, no question arose; if not, it had to be determined whether time allowed of overtaking the mail by special train and catching the steamer at Kingstown.

In the latter case, the English mails were landed and sent up to Dublin; otherwise they were carried on to Liverpool. Of course, when practicable, the mails for Ireland were always landed; but not so those for Scotland. The table was arranged to show, as far as possible, for each hour of the twenty-four what course should be followed.

When the train from Queenstown to Kingstown, the boat from Kingstown to Holyhead, and the train from Holyhead to Euston Square, are specially provided thronghout, there is no need to consider the times and the seasons, and the whole of the mails are sent through Ireland, if they can be landed at all.

When I first visited Cork, Mr. Arthur Webb, the postmaster of pre-penny-postage days, had been succeeded by Mr. Barry, a member of an ancient family of that name, which has owned the island where 
Queenstown stands since the middle of the twelfth century. It has disputed with the Roches, from perhaps even an earlier period, the sovereignty of half the extreme South of Ireland.

I am not sure whether the famous Sir Boyle Roche, who assured the House of Commons that, not being a bird, he could not be in two places at once, was a member of this family or not, his name being spelled by some writers 'Roach.'

- In any case, he was the celebrated author of a great many original remarks, the memory of which survives. It is not, however, so well known that his attached body-servant was also an unconscious humotist of the first order. When poor Sir Boyle - had paid the debt of Nature, and this good fellow wished to acquaint the late Baronet's especial friend with a change in the last arrangements, it is stated that he went to him and said, "Sir, my master sends his compliments, and he will not be buried until to-morrow night.'

The postal telegraph office at Roche's point is situated on a point of land on the eastern shore of the entrance of Cork Harbour.

It was opened in March, 1862, by the London and South of Ireland Telegraph Company, of which the late Lord Fermoy was promoter and principal shareholder. His lordship's rights were acquired by the Post-Office, who paid under the award of an umpire eight thousand pounds for a line which probably could now be put up for a tithe of that sum. The 
costs of the arbitration alone largely exceeded the prime cost of construction. I went over to Ireland to negotiate the purchase, but was aghast at the value attached to the enterprise, and soon saw that labour to bring about an amicable settlement, which both sides should deem just, would be entirely fruitless.

The importance of Roche's Point as a telegraphstation dates back to a time before the laying of the second Atlantic cable. At that period the latest news from the continent of America was obtained from the homeward-bound American steamers, which called off the Point to land mails and passengers for Queenstown.

In order that not a moment should be lost, a boat's crew of five men was ready at all hours to board the steamers and obtain from the pursers the messages which the captain, crew, and passengers wished to forward to friends at home-or through the British Isles to those abroad-announcing their safe arrival off Cork. A staff of four telegraphists was maintained for the sole purpose of despatching private and press telegrams thus landed.

The Times newspaper also kept a boat and crew in readiness for the collection of despatches. When the weather was too severe to allow of the vessels being boarded outside the harbour, the pursers had the telegrams and money, in prepayment of charges, enclosed in air-tight canisters and thrown overboard, to be picked up by the boats. Such canisters often 
contained more than three hundred messages, especially so when received from a Cunard steamer which had called off Cape Race to pick up despatches giving the latest American exchange prices and news of the Civil War which raged between the Northern and Confederate States.

Of course, on the opening of the new, cable, in 1866 , messages from America gradually ceased.

Roche's Point postal telegraph office still renders good service by announcing the arrival of mailsteamers and the departure for Queenstown of tenders conveying mails; so rendering it practicable to make the special arrangements for the conveyance of the mails through Ireland almost perfect.

But Roche's Point is not the only signalling-place for Transatlantic mail-steamers on the south coast of Ireland. There is another, ninety or a hundred miles to the south-west, which has just been the scene of a new and interesting departure in submarine telegraphy.

Twenty years ago I recollect sending by telegraph a birthday congratulation to a youngster at Hampstead, to the effect that the telegram was despatched from an old Irish tower, perched on a desolate mountain, known as Browhead, in the remote island or peninsula of Crookhaven, about six hundred miles from his home. The tower was not a luxuriously furnished abode, a huge cast-iron A B C telegraph and an empty patent mustard case being the chief items of its equipment. 
I was then on a visit of inspection. Browhead was utilized as a signal-station for noting and telegraphing to Cork and Queenstown the passing of homeward-bound packets near the Fastnet Lighthouse (nine or ten miles out in the Atlantic), that is, when they could be seen from the mountain.

The lighthouse has now been put into direct telegraphic communication with the mainland at Galley Cove, a mile or so from Browhead, by a special electrical method.

The rock on which the lighthouse stands is almost vertical, and rises eighty-seven feet above low-watermark. If a submarine cable were carried along the sea-floor and up the face of the rock, it would speedily be broken by the force of the waters, or chafed through on the sharp rocks hard by. Nevertheless, telegraphic communication has been successfully established and maintained, under the special method of Messis. Willoughby-Smith and Granville, by means of a cable which is not continuous, but which stops about one hundred and twenty feet short of the rock, and bathes its open end twelve fathoms deep in the Atlantic Ocean. It is kept in position by a weighty 'mushroom' anchor of copper.

In the ordinary way, the circuit which is essential to all telegraphic operations would be formed by an insulated metallic conductor (a cable, in short) from the telegraphic instrument in the post-office at Crookhaven, to an instrument in the lighthouse. The current would go in one direction by wire, and to 
enable it to return through earth and water to the starting-point, the conducting wire, after passing through both instruments, would be carried down at each end to the earth or the sea.

But as the ordinary way is not in this instance suitable, leakage and 'conduction' are called into play; and between them the beautiful and highly sensitive 'mirror' apparatus, invented long ago by Lord Kelvin (when Sir W. Thompson), is made to flash signals, with perfect ease, at the lighthouse from the shore, and rice-rersî.

The reader, if unversed in electricity, may gather a vague idea of the meaning of these terms from the fact that, while the bulk of the electricity sent by cable from Crookhaven flies back to its starting-point without entering the lighthouse at all, a minute portion, sufficient to deflect the mirror, leaks-in other words, darts through the water from the ' mushroom' anchor, to which the cable is made fast, to one of two wires from" the mirror instrument in the lighthouse, which are fastened to the wall of rock. They are carried down, some distance apart, below lowwater mark, and are connected to heavy cylindrical blocks of copper, known as 'centipedes.' These are jammed into the crevices of the rocks, and secured by clamps and bolts.

So, with a taste of actual electricity, due to leakage, or a sort of shamefaced scuttling over to the rock of a surplus spark or two-vibrations, as it were, from the gymnotus, or salt-water electrical eel, nine 
miles long, which has crept out from the land-the wondrous mirror contrives to reflect with fidelity signals from Crookhaven, or, similarly, at that office, signals from the lighthouse. These latter, too, are despatched from a chamber perched more than a hundred feet in the air, on the summit of a seagirt rock. Over the Fastnet it is the rule, rather than the exception, for the Atlantic waves to send at least clouds of spray, and, as often as not, to break in great billowy masses.

After this rough-and-ready, but not inaccurate, exposition, I must add a technical word or two, warranted by what one of the inventors himself tells $m \epsilon$, for the satisfaction of those who may demand a more exact explanation; althongh I admit that without the aid of a diagram it is difficult to set forth the matter with absolute clearness.

The two wires which are led down the front of the rock into the sea may be compared to the merrythought of a fowl, the inirror being intermediate at the bony apex. One wire and its ' centipede' may be considered as an earth-wire, the other as a cable-wire, although actually it is an earth-wire too.

Each time the Crookhaven battery is connected to the main cable, and a signal is thereby sent, it necessarily follows that the main cable's two earthplates-viz., the 'mushroom' submerged in the vicinity of the Fastnet, and that in the water at Galley Cove, close to the Crookhaven post-officebecome charged (together with the cable), either 
positively or negatively, according to the direction of the current. The sea around each earth-plate is similarly charged. Now, if the merry-thought, or rock circuit be so arranged that one of its ends is in the charged area of the main cable, and the other end, or earth-plate, is more or less out of the charged area, a current will flow through it, because of a difference of 'potential' between its two ends or earth-plates.

It will, I hope, be evident from the foregoing paragraph that the two earth-plates of the second, or rock, circuit act as the two plates of a battery (of extremely small electromotive force), and consequently the mirror of the receiving instrument at the apex of the merry-thought is deflected, the instrument acting as though the two ends of the rock circuit were connected direct to the two plates of an ordinary cell.

Of course, when the rock 'sends' and the shore 'receives,' the same law holds good, the nearest 'centipede' affecting the 'mushroom,' although there is a watery gap of a hundred and twenty feet between them.

In this way the difficulty, held until lately to be insuperable, of electrically connecting isolated lighthouses or lightships with the shore seems to be in a fair way of being permanently overcome. Mr. Preece, C.B., has stoutly averred before a recent committee of the House of Commons, that the word 'impossible' as regards electrical matter's does not exist. 
The Point, it must be admitted, is a long way off the track of the mail or any other coach. The nearest railway-station, and certainly the nearest town, is Midleton, ten or twelve miles distant. The small village of Whitegate is close at hand, but beyond that and a few cottages and the coast-guard buildings, which lie as it were under the shadow of Trabolgan-the home of the Roche family - there is nothing in the way of civilization to vary the monotonous occupation of looking out for the mailboats.

Yet good servants of the Crown spend a lifetime there without a murmur, undismayed by the absence of variety and by the scarcity of entertainment incidental to more populous places. When I was at Roche's Point, about twenty-three years ago, I found my good colleague, Mr. Kennedy, in charge of the telegraph-office. After thirty-four years' service he is there still.

On the Dublin and Wexford coach-road there were seven changes in the seventy-four miles; the accelerated time of running was $11 \frac{1}{2}$ hours - a low speed, it is true, but the stages were long, and the coach, unlike the English mails, was heavily loaded. It carried, when full, as many as twelve passengers, besides coachman and guard. The average pace, allowing for stops, was seven miles an hour.

Once a coach-horse presented himself in advance of the mail at his stables at Wexford. A wheel of the 
mail-coach had given way; thereupon Guard White had mounted one of the leaders, slinging the bags across the crupper behind him. The horse liked neither rider nor bags, flung them both off-the former against a bridge, the latter into the road-and cantered on gaily to his accustomed manger. The injured guard picked himself up, collected his bags, hired a donkey-cart in the Queen's name, and drove up to Wexford post-office more bruised than overdue.

Does any traveller on the down mail-coach on a certain September night of the very early sixties yet recall the momentous drive between Ashford and Rathdrum? How, soon after leaving Newtown Mount Kennedy, the wind rose; how, when Ashford clock had not long struck ten, it became the great equinoctial gale which blew down tree after tree across the mail-road, and blocked it to all traffic; and how the coach had to turn back and evade the eight-mile length, which the tempest had closed, by a long flank march ?

The coach for Wexford took me up one day at Enniscorthy. I did not then know that there was a story, if only a simple one, to be told of Miss Gill, sometime postmistress. Like the Roman sentinel at the Misenum Gate of Pompeii, she had her duty to do, and did it, though dying in the act. Soon after half-past four o'clock on a dark morning in 1861, Guard W. V. White (now of Southampton), on the down night mail-coach from Dublin for Wexford, blew 
his horn in Enniscorthy, and in a minute or two pulled up and got off the coach at the post-office.

It was lighted up, the door was ajar, the local bags he could see were tied and sealed, and ready for despatch. But there was no postmistress in waiting as usual. The door would not open freely. White pressed it hard. Some obstruction lay on the floor behind it.

The Postmistress of Enniscorthy, well stricken in years, had arisen before daylight to finish her last work. She had made out the letter-bills, and closed and sealed the mails. Then the horn blew. What it cost her failing strength to reach the door, to render her last service to the State, none may know; but no duty was left undone; there was no postal irregularity to report against the dead Postmistress of Enniscorthy. 


\section{[28I ]}

\section{CHAPTER XVI.}

TELEGRAPHS ON THE TRACK.

When statutory authority enabled the Postmaster to acquire, construct, and work telegraphs, the attention of the Post-Office was naturally directed to the highroads. Where the mail-coach had run, the postal telegraph might follow. To the erection of posts and wires on cross-roads and country lanes there could surely be no objection.

But the proof of the pudding lay in the eating. Strong opposition sprang up, and it needed all the address of the department to obtain the consent of road trustees and parish boards to the execution of needful works.

In later years, when I had advised the construction of a new line of telegraph much required, and since put up, from London to Hull, along the old coachroad by Hadley Highstone and Alconbury Hill, I found its most vehement opponent-in his capacity of churchwarden-in mine own familiar friend.

On some occasions the tact and persuasive power's of the late Mrr. Edmund Yates were turned to good 
account by the Post-Office in inducing local authorities, who demanded that the wires should be laid underground, to grant a wayleave for overhead wires. One local board in Cheshire was obdurate. Mr. Yates went down and addressed them in a convincing speech, marked by an array of unassailable facts and the use of faultless argument. "Thank you very much for your interesting speech, Mr. Yates,' said the chairman. 'But the fact is, we have just received a letter from the Post-Office, agreeing to put the wires underground, so we need not detain you. Good-day!' By some regrettable oversight, due to severe pressure of business, we had, while agreeing to give way to the local board, neglected to advise our envoy of the change of front.

In the long-run, the good sense of the country at large came to the aid of the Post-Office. Telegraphs, especially light lines of two or three wires, were not found to be so unsightly as was feared, or else the eye became accustomed to them, and opposition disappearing, all went merrily as a marriage-bell.

In looking back to the far-away past, I think that, next to my adventure with the ghost at Ipswich, the most curious experience I have ever had was a night spent soon afterwards, in 18t8, in the Primrose Hill tumnel, on the London and Birmingham railway, for the purpose of mending the telegraph.

The Euston and Wolverton single-needle wire had failed, and the fault was thought to be in a cable of several wires, suspended in the tunnel. 
As far as I can recollect, each wire was insulated, not by means of a gutta-percha coating, but by cotton yarn, twisted around it and tarred. The wire, with others, was then laid up in a rope or cable. We cut the cable, and I suppose detected the fault; but what remains on my mind is the novelty of spending some hours in a dark tunnel, a mile long-with nothing to guide one but a feeble lamp-and the necessity of looking out for the nearest alcove in the brickwork, in case a speck of light in the remote distance gave warning of the approach of a train. The alternative, as one of the party cheerfully suggested, was the selection of a spot between the rail and the wall, where one might best lie down, and, squeezing one's self flat against the tunnel side, contemplate at the distance of $a$ few inches the passage of the engine, its glowing fire-box, and the swift-revolving wheels of the train.

When mail-coaches began to fade away, the electric telegraph boldly raised its head. Letter-rates, oppressive as they had been, were moderation itself compared with the charges of the new electric post.

The latter were enormously high. The cost of the shortest message to a town two hundred miles off was eight or nine shillings, with the addition of a shilling for porterage, although the addressee might live next door to the telegraph-office of delivery, or even in the same house. A message from London to Glasgow cost fourteen or fifteen shillings.

While these rates prevailed, a clergyman came to 
the West Strand telegraph-office in 1848, desiring to transmit his sermon to a provincial address. I told him the charge would be eighty pounds. He retired, as might be expected, aghast. This was at the rate of about eight shillings for twenty words, so that the sermon must have contained about four thousand words. Such a despatch would now cost, at the halfpenny per word rate, not eighty pounds, but eight, and at press rate, not eighty pounds, but two pounds.

Similarly, I remember the great John Bright coming from the House of Commons to the same office at a somewhat later day, to send a Parliamentary despatch to a Manchester newspaper, and remarking, with severity, on the enormous cost which even a couple of hundred or so of words would involve, leaving, as it then did, but little change out of a five-pound note.

If Sir Rowland had had time to spare, he would, I think, have entered on telegraphic reform with much zest. As it was, he did what he could to help on a plan I had shaped to that end.

When electric telegraphs were first erected, a very general belief prevailed among uneducated persons that the actual message-paper itself was transmitted through the wire, as it is now through the pneumatic tube.

I recall an instance of the sort in the late forties. A message had been handed to me by a countryman for despatch. He paid the fee, and saw me hang the message on the double-needle instrument. I quickly 
signalled it to the transmitting office, and told the sender that it had gone. 'Gone!' said he; 'nay, it's there still. Put it in the machine, and send if off properly, man!' 'Oh, very well,' I replied; ' if you prefer it that way, here goes!' Then, I am ashamed to own, lending myself to deceit, I unfastened the back of the instrument, thrust in the paper, shut up the apparatus, rang the bell vigorously, and nodded to my client. He went away with a smile upon his face and a satisfied expression at having brought the youngster to book and compelled him to telegraph properly.

But one was hardly prepared for credulity of the same sort forty years later. Yet when new wires were erected north of Banbury, in 1890, an old woman in one of the villages through which they passed asked what the wires were for, and received a proper reply. 'Ah, well,' was the rejoinder, 'I expect I should have to watch them a long time before I saw a telegraph-message going along. My eyesight is getting so bad!'

An anecdote of the same sort which reached me from a town in Norfolk fits in very well with my own experience :

The heroine came to the post-office to send a sixpenny telegram, but found that her draft ran to twenty-three words, costing elevenpence halfpenny. So being, like Mrs. Gilpin, of frugal mind, she sacrificed many of the official forms in preparing fresh drafts, until at length the words were reduced to 
twelve in number and the charge to the regulation sixpence. Then the good woman begged for an envelope in which to enclose her telegram, so that its contents might be shut out from prying eyes during transmission over the wire.

More to the point still, however, is the case of a working woman, who recently came on a visit to a Lancashire town, and found that she had brought away the house-key, instead of leaving it behind for her husband's use. She promptly repaired to the Bolton post-office, and desired that the key might be sent home by a sixpenny telegram. The inability of the counter clerk to comply with her request drove the applicant away in high dudgeon. For what, then, was the use of the telegraph, she would like to know.

There are those who, on the subtle question of electricity and its phenomena, know more than the expert. A colleague once travelled in the company of a gentleman who deplored the prevailing ignorance of the principle of the telegraph. "What so simple?' said he. 'Get a magnet, and file it to a point at both ends, and swing it on the centre. Get another, and do the same. Put one in London and the other in New Zealand, with a wire between, and just as you move one, so will the other move.'

But the plan described, although somewhat startling, is not original, and, if similar to that set forth by Addison and Steele in the Spectator, is not by far so simple as theirs. Addison made two friends agree 
to provide themselves each with a dial-plate, having the letters of the alphabet arranged around it, and a magnet suspended on its face. Then, at an agreed time, the friends were to retire to their respective rooms-one in London and the other in Rome-and, pointing the magnet to the required letters, signal messages without a wire.

On the other hand, there are those who regard the telegraph with suspicion.

The post-office at Penryn, in Cornwall, has been for more than forty years, and still is, in charge of a postmistress. 'Twenty-five years ago the incumbent of the day had an uncomfortable experience of the introduction of postal telegraphy. Whether in the hurry of the transfer we had omitted to provide some of the usual fenders of electricity, or whether the season was unusually electrical, I do not now recollect; but, whatever the cause, it too frequently happened that little balls of fire, with sharp crackling reports, danced about the instrument before the naturally affrighted lady's eyes, until the service of the telegraph seemed to her on occasions to afford the prospect of immediate destruction.

However, Mrs. Tamplin stuck to her post, in spite of the alarming demeanour of the telegraph. Not so the aged sub-postmistress of a village in Essex. Nothing would persuade her that a Wheatstone's A B C was a model of quiet behaviour, and had never been known to explode. As the department declined, in spite of remonstrance, to remove it, the 
old lady preferred to resign her office, and retire from the danger's of a public post into the security of private life.

When, ten or eleven years ago, the sub-office at a village near Wolverhampton was opened for telegraph business, the sub-postmaster, who was nearly seventy years of age, could not realize the fact that words could be signalled over the wire, and for three nights in succession he walked, after eight p.m., to the headoffice, where the village telegrams had to be repeated - five miles there and back-to compare the telegrams he had dealt with during the day with the head-office copies.

Not so painstaking was the sub-postmaster in a certain town I know very well. The telegraph had just been extended to his shop, and, all inexperienced, he sent the first message to the head-office. Because of indistinct signalling, the receiving clerk required several words to be repeated. The sub-postmaster, not understanding the situation, became impatient, and at last, unable to control himself longer, he tore the line wire off the instrument, and to cool down went out for a walk.

A few years ago, at Preston, a North-Country cattle-dealer handed in a telegram, the address of which was written clearly enough, but its text consisted simply of eight strokes. The counter clerk asked if the strokes were intended for figures. The sender replied: "Call them figures, or whatever you like, so that they come out the same at the other end, 
and I'll tell you why. That telegram is going to my housekeeper; she can't read or write a word, but when the telegram reaches her she'll count the strokes, and understand that I shall be home at eight o'clock to-night.'

In the old double-needle days, I recollect that the signs for $\mathrm{F}$ and $\mathrm{G}$, and $\mathrm{X}$ and $\mathrm{Y}$, sometimes played havoc in the true meaning of telegrams. A faulty $\mathrm{F}$ would transpose 'beef' into 'beg,' and a badly signalled G, 'wig' into 'wife.' Again, $\mathrm{X}$ would take the place of $\mathrm{Y}$, and $\mathrm{Y}$ substitute itself for $\mathrm{X}$ with alarming facility and disconcerting results. I remember myself, somewhere in the forties, sending the porters at Waterloo on a hurried quest after a black boy, said in a telegram to have been left behind in the train. A dark, leather-covered jewel-case or despatch-box, it is true, was found on the cushions of a first-class carriage from Dorchester, but no forlorn little negro rewarded the strictest search.

A well-worn version of one old story, which acquires more and more power on repetition, lays the scene of action in Liverpool, to which city a barrister on circuit, who missed his wig, telegraphed urgently from Preston to the effect that his wife was locked up in the strong room.

Another, which certainly comes from Liverpool, is to the effect that a gentleman's wig had presented him that morning with a fine box; but what is possible in telegraphy is not always probable.

Numbers, at any rate, in early telegrams, were the 
root of evil; ' fifty' turned itself into 'eighty,' and ' hundred' into ' thousand,' with great ease. Figures generally comported themselves very much as they pleased. Amongst the older telegraphists, a tradition lingers of a telegram having been sent to Portugal or Spain, ordering five thousand boxes of oranges. In the course of transmission an additional cipher slipped in.

I do not know what is the actual content of a box of oranges, but will assume that it is four or five cubic feet. Now, while a fruit steamer could probably stow away in her hold five thousand boxes, or twenty or twenty-five thousand cubic feet-about six hundred tons' measurement of goods-a quarter of a million of cubic feet, as represented by fifty thousand boxes, would require several steamers. The legend mentions ten vessels in all, which in due course were loaded and despatched from Portugal, to the dismay of the consignees. On the arrival of the fleet in English ports, it may be imagined that the price of oranges ruled low.

I am not sure that, to begin with, we signalled the number of words in a telegram. If we did so, we only counted those of the text, not those in the address. But singular blunders brought about the present rule.

The late Mr. Graves was a well-known merchant of Liverpool and an influential Member of Parliament. By persistent ill-luck, the Telegraph Company caused telegrams for Mr. S. R. Graves to be delivered to another merchant, Mr. S. Hargreaves, and vice 
versî. This was a mistake of sound. The receiving telegraphist or writer omitted the aspirate, or supplied it in the wrong place.

Blunders like these could only be met by a stringent rule, which compelled the receiving telegraphist to read over as well as count the words of a telegram which his writer had written for him. Accuracy of transmission, no less than speed, was the life-blood of a telegraph company. I call to mind a shrewd remark of Sir W. F. Cooke, in 1850, when a director of the Electric Telegraph Company. 'It would be better for the company,' he said, 'to lose ten pounds than make a material blunder in a telegraphic message.'

Perhaps the most singular case on record is that in which an unusual irregularity transferred the text of a betting telegram to the address of a social message. So a lady in a North Wales watering-place, anxiously awaiting news of her daughter's safe arrival at a distant town, received a telegram duly addressed to her, and couched somewhat thus :

'Put two ponies on Marston Moor, but hold the monkey for the present.'

On presenting the telegram at the office and receiving an explanation, the recipient declared she had been quite sure that the telegraph instrument had gone wrong, for not only was the message gibberish, but it was not even in her daughter's handwriting. It is not, I think, on record what action the betting man took when he received the message meant for the mother. 
Telegraphic blunders lost none of their humour when improved apparatus replaced the old forms.

The Right Hon. G. J. Goschen, M.P., in a debate on the currency, the proper value and the denomination of coins, was reported by telegraph to have said that 'all cows should have their exact value stamped in plain figures upon their faces.' But this was clearly the result of indistinct writing. So, too, was the announcement between parentheses of 'Ironclad chairs,' following on a speech of doubtful acceptance delivered by another honourable member.

Again, the report of a cricket-match in the South of England read: "The match was commenced at twelvethirty, in the presence of a small boy'-the word 'company' having been abbreviated to 'coy,' and misread 'boy.'

I saw in print once, in the columns of a daily paper, an amusing blunder, due also to abbreviation. In long press-messages the telegraph clerks were in the habit of using certain contractions, known only to themselves, which saved the trouble of signalling long words. This was all very well if the clerks at each end understood the code, not otherwise. I think the late Lord Derby was speaking in Lancashire on the education of the young. He dwelt on the importance of certain methods of instruction for children. 'The noble lord laid special stress on simple teaching for kids,' was the telegraphic version.

' The favourite,' said the report of a race-meeting, 'won somewhat easily by a week'-a phenomenal 
performance, seeing that the race endured but a short five minutes.

The late $\mathrm{Mr}$. Charles Galbraith, who rendered great service, under Sir W. O'Shaughnessy, to telegraphy in India, and who was at one time Chief Superintendent of Telegraphs at Bombay, used to describe many ingenious and sometimes successful attempts of native employés to communicate the tenor of English telegrams, especially during the cotton famine, to outside confederates.

The messages in early days were brought in some instances by mail steamer from Suez to Point de Galle, and thence telegraphed overland to Bombay. One method was to write a telegram in triplicate, filing one copy, sending another to the addressee according to rule, tightly rolling up the third copy and dropping it out of the window. This being detected and stopped, a new plan was adopted. The telegraphist would lean his head pensively on his hand, and abstractedly tap off signals in the Morse code to his ally watching outside.

Yet a third plan in operation was to order goods of a supposed tradesman's assistant who called daily at the office-door. 'Send me sorme tea' meant cotton up; 'no sugar to-day' was the equivalent of prices down.

But the most daring attempt of all was an actual tapping of the wire, which at one point passed through the jungle. The wire had been cut and led into a small hut, and an instrument and a discharged 
operator provided. Had this dexterous fraud remained undiscovered, every message passing over the wire could have been read off, and the Bombay office have been none the wiser.

But these things happened many years ago, in the infancy of Anglo-Indian telegraphy, and were soon corrected by the growth of experience and close supervision.

The Morse code is frequently imitated by means of a two-toned whistle, the upper and lower notes being respectively used as the equivalents of dots and dashes. This plan, or one of long and short blasts, might, as it seems to me, be universally turned to account in steamships, as a means of signalling at sea at all times, and especially in a fog. But visible tapping of the fingers is the method ordinarily in vogue amongst experts ashore.

A famous mesmerist and hypnotist was dumbfounded by the fact that two of his audience were able to communicate the numbers of certain banknotes to each other by a mere grasp of the hand. $\mathrm{He}$ did not see, and could not guess, that the grasp involved a gentle tap of the fingers of one confederate on the wrist of the amateur medium.

A droll episode once followed on 'tap' signalling. Two English telegraphists were travelling from Brussels on the Grand Luxembourg Railway towards Basel. Three-fourths of the journey passed, the companions having had, so far, the compartment to themselves. At Strasburg they were joined by a 
third traveller. He seemed to be a man of considerable importance, and was well and fashionably attired.

The two friends, after the manner of Britons, secretly resented the intrusion. One 'tapped' to the other, as though drumming on his knee, "What a bore! How well he's dressed! I wish he'd go.' 'Thank you, gentlemen, for one compliment at any rate,' promptly, in effect, said the stranger cheerfully. 'I am glad you like my coat; I hope you will let me stay.' He proved to be also an English telegraphist, and was taking a holiday, arrayed with befitting splendour.

Ingenious devices, especially in the case of longdistance messages, are sometimes resorted to with a view to economy. One firm, interested in the Australian trade, were in the habit of refusing certain telegrams, which seemed to be beyond doubt intended for them. Notice of this refusal, and consequent non-delivery, was given by telegraph free of charge to the colonial correspondent, and eventually it appeared that the notice was used by the English firm as a negative answer to the Australian offer, thus saving the cost of a reply-telegram.

Other devices have been long in use, such, for example, as that of registering fifty or a hundred titles for the same firm, the use of one of the titles signifying not only the name of the firm, but also a particular fact, such as the rise or fall of the market; another would indicate exceptional activity in one of 
the articles of Australian produce; each would have a special and distinct signification.

Australian telegrams may sometimes reach this country by way of Marseilles, but my belief is that they chiefly come through Porthcurno, in Cornwall. Now, if there is a place more completely off the track of mail-coach or railway than other places, it is surely this same Porthcurno-a sandy cove, where the Eastern Telegraph Company's cable lands, about ten miles from Penzance. Here, as at Valentia, in county Kerry, may wonders any day be seen.

By means of the relay and the syphon recorder, the company transmit telegrams from Porthcurno to Melbourne, Victoria (13,695 miles distant, as the wire runs), in about two hours. An express message could be got through in less than half an hour, and with the line clear from end to end a signal has been known to pass between Cornwall and Victoria in five minutes. There are seventeen stages or lengths of telegraphic circuit; at the termini of eight of them the telegrams are repeated by human agency, at the other eight they are passed onwards by 'translation,' that is, by the automatic action of relays.

The route of the Eastern Company's telegraph is by sea from Porthcurno, viâ Gibraltar and Malta, to Alexandria; thence by land to Suez, by sea to Bombay, across the peninsula to Madras; by sea to Penang, and thence by land and sea, viâ Singapore, to Batavia, Port Darwin and Adelaide to Melbourne. Two-thirds of the distance, approximately, are covered 
by submarine cable, and for the other third the wire is carried overland.

There is one magnificent stretch of land-wire in Australia, between Port Augusta and Alice Springs, 1,036 miles, over which the telegraphists speak direct by translation. The much greater length of cable (1,662 miles) between Aden and Bombay, however, offers no obstacle to direct transmission. But the speed of working is probably lower than over the shorter land-line, aided as that is by translation.

I have never known the Post-Office to lose its head under the most embarrassing circumstances. That is saying a great deal. When snow blocked the roads, the mails still went somehow; when a storm broke a Scotch cable, still the telegrams went forward. The submarine cable across the Sound of Mull gave way in March, 1895. The season was not suitable for ordinary repairs. The Office rose to the occasion. A mile or two of gutta-percha-covered wire was laid on the ground on the Morven coast, parallel with the ordinary telegraph-wire on the opposite coast, which is suspended on posts between Auchnacraig and Craigmure, where the Sound narrows, and is about a mile and a half wide. Then, from Morven or Fort William, messages were transmitted direct to Auchnacraig, and by that office repeated to Tobermory. For the benefit of experts, I may add that the receiving instrument was a telephone, and the transmitter a 'buzzer,' an ordinary key making the usual dots and dashes. So 
messages were sent over a gap of a mile and a half as easily without a wire as with one.

As in the old time, in America, the buffalo destroyed the telegraph by using the poles planted on the plains as rubbing-posts, so did a bovine foe check this important advance in practical telegraphy. For a Highland cow, never having seen gutta-percha before, took the Morven wire, which lay upon the ground, to be grazing material of superior quality, and broke the circuit by taking a bite out of it.

The Postmaster of Teignmouth had a singular experience when a clerk at Bristol. He was on duty at the public counter, and for a moment leant his head against a gas standard, when he distinctly heard the telegraphic call, in the short and long sounds of the Morse code, 'BS BS BS V SO,' meaning' 'Bristol, Bristol, Bristol, the Southampton office wants you.' Bristol answered, and the clerk below read off and took down a message which was being received three floors above, afterwards verifying the accuracy of the transcript by a reference to the message-form in the signal-room. I think that the law of acoustics, rather than that of electricity, must be left to explain this occurrence.

The telegraph, of course, has its romance, when sorrow is sometimes turned into joy. Has the counter clerk at a certain telegraph-office in Lancashire yet forgotten the blow dealt, by an ill-chosen word in a telegram, to a poor Jew, whose wife had been taken ill at Plymouth, and how, when he came to the 
telegraph-office and entreated the clerk on duty to write a needful message for him, a timely reference to Bradshaw chased the cloud from his brow. 'Rachel departed at eight o'clock'-not, however, this life, as the stricken husband had concluded from the telegram, but by the eight o'clock train from Plymouth for the North.

Not snow-storms alone, but wind-storms, have called out the energies of the Post-Office, on the mail-coach track, in sending its mails by railway, and especially in maintaining the telegraph.

Gales occasionally traverse these islands at great speed -at more, even, than sixty or eighty miles an hour-when the telegraph-wrack is more general, and reinstallation proportionately more expensive than ordinarily in the winter.

The gale of December 21-22, 1894, was, according to a paper read before the Royal Meteorological Society by $\mathrm{Mr}$. Charles Harding, one of exceptional severity. It certainly blew trees across the telegraph lines in such numbers that in Lancashire and Yorkshire, Durham and Northumberland, Cumberland and Westmorland, in the West of Scotland and in the North of Ireland, the damage done was general, and cost many thousands of pounds to repair. For four consecutive hours the velocity of the wind exceeded one hundred miles an hour. At Fleetwood its violence was greatest; there, at nine a.m., on the 22nd, the wind blew continuously for some time at 
Rifles, and under the leadership of Colonels du Plat Taylor, C.B., and Raffles Thompson, is amnexed to the Rifle Brigade.

For a brief period in the sixties, I, too, who for years had been an ardent volunteer, held a commission in this distinguished regiment; I wish I could add that my services were distinguished also. I did, however, once for the space of a few minutes command the corps, and on that occasion address it, in Westminster Hall, in a speech which I flatter myself surpassed even that of Single-speech Hamilton, at least in brevity and point-to say nothing of the last harangue at Fontainebleau. It consisted of only four words: 'Battalion, stand at ease!' The order was obeyed with all the alacrity and precision of veteran troops, Her Majesty's servants-officers, sub-officers, and soldiery, at once standing easy.

This regiment contains within itself what really are two important additions to the regular army: (1) The Army Post-Office Corps, raised in 1882, consisting of three officers and a hundred rank and file, properly trained and equipped, and ready to undertake the postal duties of an army corps in the field whenever called up for service; and (2) a picked detachment of two companies of highly-trained and expert telegraphists, forming a reserve to the Telegraph Battalion of the Royal Engineers.

All the men of these three companies are medically examined, and enlisted under the same conditions as other army recruits. They are at once transferred to 
the 1st Class Army Reserve, the 24th Middlesex Rifle Volunteers being responsible for their training and efficiency.

Both these organizations have been tested by actual service in the field. They were utilized in the British expeditions to Egypt in 1882 and 1885, and the approved work which they did on those occasions seems to justify the position which they hold in the Army List.

Besides this, the Post-Office has for the last twentyfive years actively co-operated with the War-Office in training young men of the Royal Engineers in the use of various forms of telegraph, particularly the 'sounder'; and it still employs a certain quota, for a sufficient period, as clerks in various telegraph-offices. A number of these military telegraphists rendered good service during the expedition to the Soudan in 1885, for the relief of General Gordon, at Khartoum.

Colonel Beresford, R.E., who has been associated with postal telegraphs at home, is said to have related an incident abroad in which the military clerks and the 'sounder' figured. The story is to this effect:

'At the action of McNeill's zareba, the telegraph was at work in the fighting line. The cable had been laid out with the troops as they marched out towards Tamai, and on forming a zareba, a "sounder" was set up, and communication opened with the base. In the confusion occasioned by the sudden attack of the enemy, the instrument was lnocked over, and the clerk (Corporal Bent) had to take part in the defence. 
The fight lasted about twenty minutes, and immediately on the Arabs being driven off, a new instrument was set up, and several messages, including one for the Times and one for the Daily Neus, were sent forthwith.'

Telegraphy brought me into communication with a good many people of note in the course of years. I remember that, about 1854, during the progress of the Crimean War, I delivered into the hands of Lord John Russell, then Prime Ninister, a telegraphic despatch relative to an attack on the Redan, a fortified work outside Sebastopol, when a famous young officer, afterwards known as 'Redan Massey,' distinguished himself-as, indeed, did all the soldiery more or less-by brilliant acts of heroism. As Lord John, a small man of grave aspect, read the despatch, Lady Russell exercised a wife's privilege of looking over her husband's shoulder. His lordship was making a sort of official progress, and I intercepted him on the platform of a railway-station, anticipating H. M. Stanley's salutation to Livingstone in the African desert by a raising of the hat and a 'Lord John Russell, I presume.' I wish I had preserved the acknowledgment of delivery he gave me as a fragment of the historical past.

The late Earl of Carnarvon was somewhat of the build of Lord John, but he was as eager and ready of speech as the other was sententious and grave. About twenty years after my rencontre with Earl 
Russell, Lord Carnarvon, desiring to secure telegraphic accommodation for the villages included in his Berkshire estate, came to see me at the PostOffice, and we pored over the Ordnance map together, he describing clearly and readily his wants, and I explaining what the department had in view. His lordship was very pleasant to deal with, and showed no disposition to stand out for more telegraphs than the department could reasonably be expected to establish.

Very different from either was the late Earl of Lucan, whose tall military figure marched into my room in the General Post-Office (West) one fine day in the early eighties, just thirty years after the Balaclava charge, which he directed in the Crimea, to discuss arrangements (postal, however, rather than telegraphic) affecting his Irish estates.

I am afraid I lent but mechanical attention to the subject of conversation, my thoughts being absorbed in contemplation of the man who, in actual obedience to Lord Raglan's orders, or by tragical misapprehension, contributed so sanguinary, if glorious, a page to the history of the Crimean War. 'C'est magnifique, mais ce n'est pas la guerre!'

A well-known apparatus in connection with electrical processes is termed a switch. It fulfils much the same purpose as a railway-switch, diverting the accustomed path. A colleague of mine was testing submarine wires at the cable hut at Greenore Point, in the South of Ireland. A lady and her grandchild 
looked in at the open door. They seemed interested, and the honours of the little shed were done to them. On resuming duty, while the visitors still lingered, the electrician said to his assistant, 'I wish we had a reversing-switch.' The visitors disappeared, only to return from a thicket hard by with a bundle of twigs neatly cut, which were shyly tendered, and a hope was expressed that one of the switches might do. 


\section{[ 306 ]}

\section{CHAPTER XVII.}

PILLARS OF THE PAST.

There are colleagues of bygone days still living who served in the Post-Office under Colonel Maberly. I never had the opportunity. He was transferred to the Commission of Audit in the year before my own appointment to his old department, and I only saw him once in the City, for a few minutes, when he was advanced in years, and had fresh interests to occupy his mind.

After Freeling's death, the Post-Office was not left long without a permanent chief. On September 29, 1836, Lord Lichfield appointed Maberly-LieutenantColonel William Leader Maberly, to give him his full style-to be the Secretary.

It has been the fashion somewhat to depreciate the public services of this capable officer, and to regard him as one disposed to obstruct rather than facilitate the progress of the Post-Office. But I believe the contrary to have been the fact, and that Maberly's opposition to penny postage arose, in the main, from a natural reluctance on the part of a newly-appointed 
official to encounter the sacrifice of revenue which the inception of the scheme involved-reluctance which, looking at his position, it is hard to decry.

Maberly found himself in the responsible and difficult place of custodian of a branch of the public revenue which seemed to be in a decaying state, and the productivity of which it was his laudable ambition to restore. He found himself, too, the successor of a Secretary who, for nearly forty years, had, with sterling ability and remarkable success, wielded almost unquestioned sway. He was followed, as we know, by a reformer who, brilliantly capable, originated a plan overwhelmingly popular. Between these famous men the ci-derant Colonel of Foot has suffered partial eclipse.

Maberly and Lichfield were not alone in their opposition to penny postage. Even when the great measure had been some years in operation, and monetary success was in view, its popularity had not entirely silenced opponents. So great an authority on public finance as McCulloch, the statistician, and writer on political economy, in his 'Account of the British Empire,' expressed the opinion, as late as 1847 , that to change from an average charge of sevenpence or sevenpence halfpenny to the uniform penny was ' to rush from one extreme to another, and to endanger a considerable amount of revenue without any equivalent advantage.' He held the view that if Scotch and Irish letters for London had been rated at sixpence, and other letters in proportion, and had 
mercantile circulars been allowed to pass 'under covers, open at the ends, at a penny or twopence each, the clamour for a uniform rate of penny postage would have died away.'

McCulloch no doubt weighed the matter only as a financist of the day, and took no account of the prospective incentive to commerce of cheap and uniform postage, and the moral and social aspects which it presented. He expressed a wish that he could come back in about three hundred years to see the result of the political and economical principles in action in 1842.

Colonel Maberly was only thirty-eight years of age when he became Secretary, and was, therefore, in the prime of life. He had served in the army from 1815 to 1832 . 'When my husband and I were quartered at Bermuda,' said the wife of an old sergeant of sappers, forty years ago, 'there was much insubordination, and a good deal of flogging in consequence. Some fresh troops arrived, and with them Colonel W. L. Maberly. He took command as senior officer on the station. From that day, sir, there was not a single case of flogging, but excellent discipline was restored and maintained.'

The Colonel had long been a Member of Parliament; in fact, with short intervals, from 1819 until 1834, or later. He had represented during that period Westbury, Northampton, and Shaftesbury in the unreformed House, and Chatham under the Reform Act of 1832. So he was a practised politician. As Clerk of 
the Ordnance, he had been a member of the Government, and therefore was not unacquainted with the drift of public business.

Young, vigorous, experienced, and Lichfield's personal friend, Maberly was the very man to give effect to his chief's ideas of progress, and even of reform. He did his best. There has, probably, been no more painstaking officer of the department than the Colonel -none who stamped his mind more thoroughly on every minute and draft that came before him. He was made a Commissioner of Audit in 1854 .

In person, Maberly was tall, broad-shouldered, and soldierly. Mr. Henry R. Page, who, in the late forties or very early fifties, daily took papers to him for instructions, speaks of him, as others have done, with affectionate regard, to this day. 'He certainly secured the strong personal attachment of many of his officers,' writes Mr. Page. 'Perhaps a good way of putting it would be by saying that not a few of us felt proud of serving under him, and had a most loyal liking for him as our chief.'

As a soldier, the Colonel could express himself with directness and force. Mr. Hodder, in his 'Life of Sir George Burns,"* relates the particulars of a discussion regarding a proposal of Burns to carry the mails without charge (as he did for many years) between Glasgow and Belfast :

"When Colonel Maberly heard the offer, he exclaimed, "Burns, you are a fool!" However, he sent * 'Sir George Burns, Bart.' Hodder and Stoughton, 1890. 
for Mr. William Page [then, and for many years afterwards, head of the packet branch of the Secretary's office], and they discussed the matter fully, when, after hearing the details, the Colonel said, "No, Burns is no fool. He knows what he is about!" "

The Colonel obviously did not deal in delicate euphemisms, such as would remind me of a remark, made in the twenties, concerning the writings of $\mathrm{Mr}$. W-, a police magistrate. The latter had encountered, while out riding, a heavy fall, being thrown on his head on a hard bank. That he experienced no unpleasant results he attributed to his habits of exercise and a careful diet. But the critic, in noticing this story, wrote that 'Mr. W- ought certainly to know best, but our equally confident conviction is that the escape was entirely owing to the original firmness of the exterior defences of the brain.' Maberly, in this case, would certainly have gone straight to the point, and expressed his meaning in terms much briefer but not less explicit.

The net revenue of the Post-Office, which had been declining before the new Secretary's appointment, certainly did not lose way under his supervision while the high rates still obtained. It was in 1838-39 a quarter of a million more than it had been five years earlier.

I do not think the Colonel could have given much attention to the development of mail-coaches. His inclinations might have leant that way, as he was a judge of a horse, and (I believe) hunted the Surrey 
Fox-hounds. But the occasion was swiftly passing, and he had rather to arrange for the conversion of mail-conveyance from the road to the rail, the transfer of the money-order system from private to official hands, and the transit of Indian letters by way of the Mediterranean (thus disestablishing the route by the South Atlantic). He was perhaps at his best in dealing with men, and especially with large bodies of men. He knew how to conciliate and control. His name was widely known long before his retirement.

Colonel Maberly died in February, 1885. His sister, Lady Adean, and his half-brother, General Maberly, survive him.

In 1854 came into power, as full Secretary, the Great Reformer.

A modern Post-Office book naturally includes a page specially devoted to Sir Rowland Hill, and I should be sorry for this volume to be in that respect an exception.

But, as a matter of fact, Sir Rowland became Secretary of the Post-Office only when mail-coaches had passed out of the region of practical postal politics. The railways, as channels of conveyance, reigned supreme.

It was in 1837 that the coaches attained the zenith of their success, and it was then, also, that their splendour began to decline. Rowland Hill was still hard at work on his plan of postal reform, which, 
even if it contemplated the mail-coach as an agent, had no special reference to its further development. He had formed his scheme in 1835; in 1840 it bore fruit; in 1842 Hill was, after temporary employment on postal matters at the Treasury, sent to the rightabout as superfluous; in 1846 the Ministry of Lord John Russell brought him back again to share in a dual management at St. Martin's-le-Grand; but it was not, as I say, until 1854 that he actually became Secretary of the Post-Office.

By that time nearly all the great trunk railways were open, or had been planned, and were fast approaching completion. Mail-coaches had almost wholly disappeared from the road.

The reformer must have based the success of his scheme on railways, for without their aid cheap and uniform rates of postage, as we know them now, could never have come about. This is not saying that penny letter-postage, pure and simple, would have been impracticable and unremunerative by mail-coach. Such a conclusion is by no means certain.

Under the postage rate of a penny for the weight of half an ounce, inland letters produced on the average $1 \frac{1}{4} \mathrm{~d}$. apiece, and ran in number $25^{\cdot} 6$ to the pound. It was reckoned that, although mail-coaches on the average carried only about three hundredweight of mails, they could, if necessary, be loaded up to fifteen hundredweight. At that rate, a full load in one direction would represent 42,840 letters, which 
would produce $£ 223$, and in both directions of course double that amount.

If one-fourth be allowed for coach-conveyance, $£ 111$ would be available as a payment to the coachcontractors. It is not easy to say what was the average distance traversed by a letter. Nowadays, it is found that local letters form a very large proportion of the whole. In mail-coach days, it is probable that neighbouring towns, rather than very distant ones, had the most correspondence with each other. So perhaps a hundred miles would be a fair basis of calculation.

The Post-Office paid various rates for mail-coach services; but at a shilling the double mile, coach and horses, going and coming a hundred miles, would not cost more than five pounds per diem. So an available income of $£ 111$ would leave a very large margin, not merely for incidental charges in connection with coach-service, but for disturbing factors in this rough estimate.

Printed matter at a halfpenny per two ounces, and newspapers at a halfpenny for practically any number of ounces-not to speak of post-parcels at the present average postage of fivepence halfpenny for a little less than an average weight of three pounds-necessarily would swamp the calculation altogether, a result which, perhaps, may be in the minds of those who contend (rightly enough) that the Post-Office could not get on without the railways.

Only it is as well to bear in mind that a small 
letter, weighing five-eighths of an ounce and producing a penny farthing, is very different, when viewed as a remunerative item, from a bulky postal packet, weighing a varying number of ounces, and carried and delivered for a halfpenny.

Twenty years, nearly-eighteen, at all events-had passed since Freeling's death. Mail-coaches were well-nigh forgotten at the Post-Office. A new ruler, who had little sympathy with the ways of those who had gone before him, presided at St. Martin's-leGrand. His thoughts were bent on fiscal reform. Mail-coaches, for the reasons given, could have no place in the range of his mind.

'Within these few years,' narrates a writer in the late thirties, ' a plan of singular boldness and ingenuity, and developed with the utmost perspicuity and fairness of intention, has been put forth by $\mathrm{Mr}$. Rowland Hill.' He was necessarily intent on working it out by means of the rapidly-extending railway system.

So I have nothing whereby to associate Sir Rowland Hill with the older days; he was never actually on the track of the mail-coach.

Yet in the late forties, when Hill, holding an anomalous position on the establishment, had commenced duty at the Post-Office, I remember an effective contrast, to which he may have assented, between lumbering ugliness and grace and swiftness, which recalled the old glories of the road.

Postmen were despatched on their rounds from 
the General Post-Office in closed omnibuses of the heaviest build and gloomiest design. They were named accelerators, as being the means of depositing the men at the beginning of their walks sooner than they could reach them on foot. No doubt the accelerators did so ; but, rudely built and poorly horsed, they were an eyesore in the streets.

On the other hand, the late Mr. Macnamara, who contracted for conveying the mails to the Metropolitan boundary on the Great North Road, put on light, elegantly-built and splendidly-horsed four-in-hand omnibuses-Royal Mails, in short-which started from the Post-Office yard and ran to Hadley Highstone in about an hour and three-quarters. They would have done it in the old mail-coach time-an hour and twenty-four minutes-but for the fact that the easier road under the Archway was superseded by the terrific pull up Highgate Hill, as mails had to be exchanged at the post-office on the top of it. There was also a stop of four or five minutes for local sortation near Brown's Wells.

Otherwise the beautiful horses, a gray team and a chestnut, with which the mail was equipped, were equal to ten miles an hour. They excited admiration all along the road, being compact little nags of about fifteen hands high, the wheelers full of go, the leaders of action, and both of good substance. It was a joy to ride behind them.

If this were a coaching-book pure and simple, where it is customary to toss men's names about, as 
'knights of the box' whose fame should be preserved, I would say that there never could have been a finer whip in a scarlet coat than Ansdell, who drove the chief mail, nor a smarter guard than the justly esteemed Bob Lloyd (or, as Ansdell, with a fine Norfolk roll of the tongue, addressed him, Rāabert), who blew the rousing horn behind it. The inn at which they changed-the Wellington, at the northern foot of Highgate Hill, where the more or less ancient roads join-though somewhat altered, still, I think, stands.

When Hill set his hand to the plough, it was not alone postage-rates that called for reform. All the machinery of the Post-Office needed to be overhauled. The mails on the main coach-routes ran swiftly enough, but when it came to dealing with letters sent 'forward' on London, for retransmission, delays occurred which now seem incredible.

The town councils of Uxbridge and Gravesend would certainly have something to the purpose to say at St. Martin's-le-Grand, at Westminster, and in the daily press, if letters written at the former town after post-time on Friday night were not, in the ordinary course nowadays, delivered earlier than Tuesday morning at the latter town.

In any case, a through letter, which came into London in the early morning, lay there until night, so the third day was reached before it could be delivered. As the forward letters were as much as a fifth of the total number of chargeable general post 
letters brought to London, it will be seen how large and serious the question had become.

Even on the main roads there was much to be corrected. If two letters were put into the proper district receiving-house in London, between five and six o'clock in the evening, one addressed to Highgate and the other to Wolverhampton (118 $\frac{3}{4}$ miles from Highgate Archway on the same road), the Wolverhampton letter would be delivered first.

These were some of the illustrations with which Rowland Hill enforced parts of the case which he put before the public.

In London, and what have become the suburbs, despite twopenny posts, threepenny and fourpenny posts, collections were few and deliveries sluggish. In fact, to transport letters between London and Hampstead, Rowland Hill found, to his surprise, required, under the most favourable circumstances, about ten hours. Perhaps a fourth of the time may now suffice.

One of Hill's important devices for facilitating the operation of his scheme was the prepayment of postage by means of small paper labels, representing a duty of a penny and twopence, and rendered easily adhesive by a 'glutinous wash' at the back. I have before me a return which is an indication of the important service rendered by the Inland Revenue department to the Post-Office in supplying these duty labels, otherwise postage-stamps.

The figures are so vast that I hardly know what 
exactly they express, a row of ten numerals being somewhat beyond ordinary comprehension. At any rate, 2,632 millions of bits of paper are stamped, gummed, and sent annually to the post-offices of the United Kingdom, under the supervision of the Controller of Stamps, Mr. J. S. Purcell, C.B.

The penny postage and receipt label absorbs more than two-thirds of the total; and halfpenny equal now, as nearly as possible, half the number of penny stamps. Only seven million fourpenny, but nearly fifteen million of fourpence halfpenny, as also only two million tenpenny stamps are used in a year; of shilling stamps, ten million are issued. These singular disproportions are largely explained by parcel-post requirements. I print in the appendix a full statement of the issue under each rate of postage.

Speaking of postage-stamps, it is known that the blank margin is useful in many ways. Once, at a Midland post-office, a little girl came to the counter and asked for some 'plaister' from the postage-stamps. 'What do you want it for?' the postmaster asked. The girl replied, 'Please, sir, we want it for mending feyther's nose.'

It is not a little surprising that the intuitive genius of Sir Rowland did not at once catch at the idea of freely employing pillar letter-boxes as cheap and powerful incentives to letter-writing. But although he inclined to their use, I doubt if at first he was warmly disposed in their favour. Perhaps to work out 
the main features of the great scheme he was engaged on alone demanded all his enthusiasm.

The origin of the boxes is not as clear as it might be. They were certainly not a British invention, having been long in use abroad before they were adopted here. Such as we originally contrived were heavy and inartistic, not to say extremely ugly.

The first official trial of pillar-boxes was a timid experiment in the Channel Islands in 1840. By degrees they became general, and their appearance improved. I have an impression that there was a specially constructed pillar letter-box of rather magnificent design, though I cannot recollect its exact position, in the Great Exhibition of 1851. If so, it should be existent somewhere. Wall-boxes still preserve a Spartan simplicity of elevation.

There is a surprise in store for some investigator of a later age than Macaulay's New Zealander. Far down in the bowels of the earth-that is, flung into disused coal-mines in Warwickshire-by thousands, are obsolete enamelled plates removed from wall and pillar letter-boxes and post-offices. They are, I presume, to a large extent indestructible because of the enamel, and they will form the subject of curious speculation on the part of those who dig hereafter for traces of our time.

The Postmaster of Newport, in the Isle of Wight, told me that he saw a nest of birds (tomtits, he believes) in a private letter-box attached to the gate of a farmhouse. The birds had built their nest and 
hatched and fed a brood of fledglings, although letters and newspapers had been arropped into the box almost daily. The nest must have been built safely in a corner, otherwise a rain of correspondence would have fallen on the young birds. The postmaster also told me that, there being a difficulty in opening the lock of one of his wall-boxes, it was found on examination that the obstruction was caused by the deposit, by bees, of honey in the lock.

One of the wall-boxes in the Isle of Wight is situated near the entrance to an avenue, in which the owner has placed a private letter-box. Meeting a vendor of hot muffins and crumpets in the street one day, the former requested the latter to put sixpennyworth into his box. The vendor engaged to do so, and, on reaching the entrance-gate of the avenue and seeing the wall-box, took it for granted that that was the private box. So he crammed through the slot the whole of the muffins, which in due course were collected for the night mail 'up,' though in what way the sorters treated the irregularity is not upon record.

It is not unlikely that the first letter-boxes in British dominions were those fixed in Melbourne, Victoria. At all events, although it was only in 1837 that a post-office was opened in Melbourne itself, there were in 1846 at least two letter-boxes in the town distinct from the box at the post-office. One was fixed in the wall of the watch-house in one direction, and the second in the police-office, in the other direction. 
These boxes were intended for the deposit of unpaid letters. With a fine disregard for public convenience, amazing in a new colonial district where democracy surely held up its head, the collection for the night mail was made in the morning, and, as a natural consequence, no more than a letter a day rewarded the trouble of clearing the boxes. Yet Mr. Kemp, the postmaster, had a high character for intelligence and zeal, and must have had some sufficient, but unexplained, reasons for this curious arrangement.

Mr. Frederic Hill, while working with his brother at the Post-Office, became aware of an order given by the Postmaster-General of the day for all letters addressed to him to be put on his table. He found thereon next day heaps mountains high.

History did but repeat itself. I came across an anecdote the other day which shows that a hundred and fifty years earlier King George II. gave Sir Robert Walpole a similar order, i.e., to submit to him every paper of consequence before taking action on it. The machinery of State being thus threatened, Robert and his son Horace, on that occasion at least, laid their heads together.

Next day a waggon-load of papers was sent down to the King, the Prime Minister apologizing for the short supply, but assuring His Majesty that in a few days quite twice as many would be ready for perusal. So the royal order, issued the one day, was hastily withdrawn or suspended the next, and was nerer heard of again. What happened to Sir Robert in 
the eighteenth century occurred, much after the same fashion, in the consulate of Sir Rowland in the nineteenth.

Hill used to describe the Surveyors as the 'eyes of the department.' They certainly had, and have still, to look about them betimes. They must be ready at all hours to supervise the machinery of their district. On one occasion there was an especial reason to take particular note of the working of a certain night mail cart in the South of England. One of my colleagues of the Secretary's office was at that moment travelling with the Surveyor. The two officials rose at about four a.m., and posted themselves a mile from the town to watch for the cart's arrival. They were speedily noticed by a vigilant policeman, who thought that at that untimely hour they must be hanging about for no good purpose. He therefore 'shadowed' them all the way to their lodgings, took a note of their address, and then came confidentially to warn the postmaster to be on his guard, as two suspicious characters had been seen that morning watching the arrival of the mail, and no doubt were preparing to rob it.

Akin to this is the experience of a provincial clerkin-charge, or temporary postmaster. There being a deficiency in the accounts of an Essex sub-postmaster, he went down to take over the control and hold what balance in cash was available. The sub-postmaster was absent, raising money to make good the deficiency ; his wife was deaf, nervous, and naturally 
perturbed. A lodger, getting wind of the handling of the balance, suspected fraud. He communicated with the police, and the village constable soon made his appearance, announcing his intention of remaining in the post-office as long as the clerk did. 'Then,' said the latter, ' as I have taken rooms here, you will probably have to stop for three or four months.' 'Indeed!' replied the constable. 'Well, as you say you are on Her Majesty's service, and are lodging here, I suppose it is all right; but I made sure, the moment I saw you, you were one of the gang of thieves now engaged in robbing post-offices.'

One of Hill's considerable achievements, which he could hardly have ventured upon had mail-coaches been his sole resource for the conveyance of lowpriced postal packets, was the establishment of the book post.

It is not clear to me how so logical a mind as his satisfied itself of the equity of rendering, at a low charge, for one kind of postal article, precisely the same service for which it claimed a higher charge when it was required for another kind. But saving clauses, such as providing that the ends of the cheap post packets should be left open, and retaining power (never exercised, to the best of my knowledge) of delaying them in the post-office, perhaps reconciled the reformer to a departure from uniformity of charge.

Of the value, however, of the boon conferred by this beneficent measure on readers, writers, printers, 
publishers, and some other classes, there surely is no doubt.

A little anecdote of the early days of the book post is worth preserving. To Bertram House, at Hampstead, where Sir Rowland had taken up his abode, once came, on the institution of the book post, the late Professor De Morgan, to suggest a relaxation of the rule which forbade writing of any sort in a bookpacket. Was the lover of old books, urged the Professor, to be debarred from sending a volume to a friend, except at the cost of letter-postage, simply because within was written the legend:

\section{'Anne Price, Her Booke.}

May she have Grace

Therein to looke'?

Sir Rowland admitted the soft impeachment, and forthwith amended the rules.

It is not unlikely that, much to the public advantage, the concession then made virtually opened the floodgate which has let into the book-post an influx of postal matter so striking, as still, in the forty and forty-first reports on the Post-Office, to call for special observation. 


\section{[ 325 ]}

\section{CHAPTER XVIII.}

\section{A FUTURE FOR THE GLEBE.}

Writing now at the close of the century, the beginning and middle of which were adorned and enriched by the fruitful labours of the two great Secretaries of the Post-Office-Freeling, with his mail-coaches, in the Georgian, and Hill, with his low rates of postage and ever-increasing postal facilities, in the Victorian erathe conviction steals upon the mind that the genius of the two may have made the way easy towards the solution in part of a great economic problem which surely is one of the embarrassments of the day.

The denuding of the rural districts of their population, and the flocking to the towns of the sons of the soil, seem to threaten England with a disaster the like of which it has never yet encountered. For it is the glebe, after all, which produces the food, if it is the town which receives and consumes it.

It is no part of my plan to seek deep down for the causes which have conspired to initiate this proletarial hegira, nor am I qualified to do so. All I propose to show is the potentiality of the State, by 
the agency of one of its departments, to take at least a step towards checking the movement-possibly towards reversing its direction. The means are ready to the hand in the parcel post, day mail conveyances, and local telephonic exchanges.

My conviction is that by a liberal use of these powerful accessories of commerce and social life, exercised through the agency of the Post-Office, the aspect of the rural question may, in less than a generation-perhaps in a decade-be wholly changed for the better. The resources of the Post-Office are practically inexhaustible; those of the telephone-the vital importance of an extended use of which has been insisted on by many high authorities-are as yet undreamt of.

Naaman the Syrian hesitated to bathe in the river Jordan because the proposed remedy appeared to him to be too simple to be a true one. But sometimes, as with Naaman, the simplest is the best, the most effective, the only cure.

The country is deserted for the town because wages are better in the latter and life more cheerful than in the former ; in other words, because in rural parts the proportion of employers to the working classes is too small, and labour there has, so to speak, become a drug in the market.

The person of private means, or the prosperous townsman, shrinks, for the most part, from a purely rural abode. He foresees, or has experienced, the difficulty of supplying the needs of civilization. The 
small producer gives country districts a wide berth because of the difficulty of disposing of his wares. Who is to consume the butter, eggs, and poultry of a farm, if there be few or no local residents to buy them? whose horses are at hand to eat up the hay, the beans and the oats which the district may produce?

The cottager at this moment may inquire in vain how he is to convey his basket of garden-stuff-freshlycut flowers or honey-into the town at a profit, if he has to sacrifice his day's labour and take them in himself. How is the doctor to be quickly summoned by those who have not the means of employing a mounted express? How are varying supplies from the tradesman to be readily ordered and obtained by the house in the country several miles, or even a mile, from the town? Still more, how may an outbreak of fire be quickly subdued, and not improbable burglars deterred or quickly repelled? The telephone alone can furnish a cheap and effective reply.

The night mail usually arrives at the post-town in the small hours of the morning, and the rural postman starts with the letters at about six o'clock, before a single shop-shutter is down. Therefore he cannot take out parcels posted that morning; the shops are not open to make them up, and the post-office is not open to take them in.

In some cases, a second despatch, or day mail, is already sent off from the head post-town to the rural district. It is most frequently taken by foot 
messenger. According to my plan, it should be forwarded by a conveyance supplied under contract, and fitted for passenger and parcels traffic-a Bianconi's car, in short, starting early in the forenoon, being limited in its fares by a published tariff, and conforming to regulations analogous to those which control Metropolitan vehicles. Where a day despatch is not already established, a foot post, at any rate, should follow the first delivery, unless, by local arrangement, a mounted post could be employed at reasonable cost.

Every village would thus have two posts on weekdays, one giving the present accommodation, the other bringing out letters, parcels, and stores ordered by letter overnight or telephone that morning. This alone would be a postal boon of magnitude. In the reverse direction, the mounted mail would take in produce for next day's consumption. Without passengers, such a conveyance as I am thinking of would cost ten pounds per double mile per annum; with passengers, perhaps five pounds; and as traffic grew, the cost to the Post-Office would necessarily diminish, because a lower mileage rate would be accepted by the contractor.

Since the establishment of the parcel post, a great many rural foot deliveries have been turned into mounted deliveries, and every year the number increases. Where these exist, a part of the scheme is already provided for, all that is needful being the conversion of a mail-cart into a passenger-car. Where 
no second mail arrives at the post-town, there would be difficulty in justifying on purely postal grounds a second despatch to the villages. There are, however, I believe, in England and Wales only two such towns.

The parcel post recognises a uniform rate of postage. I own that in the past I have seen, and I still see, great difficulties in departing from uniformity; but in a national emergency difficulties must be made to vanish, and they should in my view be brushed aside in this case.

An eleven-pound parcel costs in postage eighteenpence. The rate for one of similar weight between post-town and village, served by a road conveyance, under these suggestions may be fixed as low as sixpence, and yet be made profitable. Lighter parcels might pass at lower charges. Such would be the distinction-by rail one rate, by road another and much lower one. It would, in my judgment, be impracticable-in fact, under this plan, unnecessaryto distinguish between the contents of one parcel and another; and that with the object of sending one class of produce at a lower rate than another class.

The telephone, which I regret to see a statesman of weight regards as a luxury of the rich, is, from my point of view, a necessity of the poor. The public have little idea of its enormous social and commercial importance to all classes, nor how cheap and easy telephonic communication can be made if the State choose to give its mind to the matter. 
Not in my opinion alone, but in that of persons who can speak authoritatively on the subject, is a telephonic exchange needed in every town and in every considerable village. A wire from town to country, where poles are available, costs annually for interest on first outlay, at two and a half per cent., five shillings per mile per year; for maintenance, from ten to twenty shillings. Where new poles have to be provided the added cost is five shillings for interest, and from fifteen to thirty shillings for maintenance. An expert holds the opinion that twenty-four shillings will suffice to maintain both the poles and the wire. A telephone made without the middleman costs but a few shillings; it need be no more expensive than a Waterbury watch.

So the annual cost of keeping up a mile of telephone-wire ranges at the most from twenty-five to forty-five shillings, and even allowing for the doubling of the wire, three pounds would probably be an outside average. Perhaps even two pounds a year per wire would in practice cover everything.

The prime necessity of a liberal extension of the telephone in the direction indicated, I mention here, not as an original suggestion of my own, but as an essential feature of the plan propounded in this chapter. It has been urged in a general way more than once by a Nember of Parliament who has for some years past directed public attention to details of postal economy, and it has been advocated in the public press, and before a Select Committee of 
the House of Commons, which sat in the spring of 1895, by Major-General Webber, C.B., of the Royal Engineers.

This gentleman is especially fitted to guide opinion in the matter, inasmuch as he served under the Postmaster-General for many years in maintaining, with the aid of two companies of his corps, postal telegraphs over a wide area. He has also, since 1880 , given close attention to telephony in its several aspects.

Moreover, General Webber laid his plans, in the shape of a full explanatory and figured statement, before the British Association, at Ipswich, in September, 1895, without, as far as I am aware, any of its calculations being successfully impugned.

There would seem to be a general consensus of opinion that a liberal use of the telephone in rural districts would be of immense advantage to the State. How the telephone should be provided, by whom and under what conditions, may be matter of opinion, and is, in any case, of secondary importance. The primary object should be, by hook or by crook, to bring the telephone within the reach of everyone.

The Postmaster-General could to-morrow lay on day mail conveyances to any point he pleases, and, subject only to the vote of Parliament for supplies, he can put up telephones wheresoever he thinks fit. Even as regards parcel post rates, the Post-Office, with the consent of the Treasury, can do much. In 
fact there is no lack of power ; it is national sentiment alone which needs to be aroused.

As regards postal distribution, it is merely a question of cost in each case whether a line of post shall be left to be wallied by a foot-messenger, or made a mounted post at the extra outlay of a few shillings a week. As regards the telephone, difficulties are presented by a paper (No. 267) laid before Parliament last year, according to which the Postmaster-General has parted with his rights in the provinces-at any rate, to the extent of assigning 213 districts, urban and rural, to other authorities.

Whether this arrangement has been ratified or not, and whether it is susceptible of modification, I do not know. Parliament, which binds, can, however, loosen; and it may be that the arrangement which seems to shut out the Post-Office from telephonic action in rural parts, really lets it more easily in. I do not profess to judge. My preference would be for telephones in a hand which is directly controlled by Parliament, and that the hand of the Post-Office. Such a view seems, also, to be favoured by the bulk of the evidence taken by the Select Committee.

But no insuperable difficulty occurs to me, in the working out of such a scheme, as is presented in this chapter, by the Post-Office in conjunction with any telephone company. A company could contract for, supply, and maintain telephone-lines either on its own responsibility or as the agent of the department; and to the advantage of both. 
A telephonic exchange in a town, according to ideas which I think will be generally accepted before long, ought to be fixed at the head post-office, with short wires radiating to every professional office, private house, or shop that chooses to pay as rental a sum which may be lower and need not be greatly higher than five pounds a year. Similarly, in a village, there should be either a call-office at the sub-postoffice, or an exchange with short wires radiating to renter's' houses. A single wire, or a loop, a mileperhaps five miles-long, would stretch between the post-offices and connect both centres; gossamer filaments uniting two electrical cobrebs. MajorGeneral Webber, in his evidence before the Select Committee, termed these country systems the 'capillaries of the great national system.' For the purpose of this chapter, I limit myself to their local utility. Where the annual charge would be less than five pounds, purely local communications are in view; where it would possibly be more than five pounds, communication through two exchanges is contemplated.

In other words, telephonic communication from one part of a village to another part of it, or, similarly, from one part of a country-town to another part of the same town, can be very cheaply provided and maintained. When a renter in the village requires the means of telephoning to a renter in a neighbouring town, and two exchanges are put in action, the cost is necessarily somewhat enhanced. 
Many of the obstacles which a year or two ago might have attended the adoption of these suggestions have been removed by the Parish Councils' Act. The villages are now in a position to treat with the Post-Office for such privileges as it may choose to afford under guarantee, and as the plan herein advocated could not be put in operation at once everywhere, a reasonable preference might be given to those who were first in the field with applications, or first by formal resolution to secure the department against loss of revenue, if the capital outlay for instruments and lines had to be incurred by that department.

The parcel post and the telephone would then receive a generous impulse, and while timid politicians might shrink from any enlargement of the responsibilities of the Post-Office, Parliament would know how to brush such fears aside, devise checks, and take sufficient precautions. In fact, if the telephone companies contracted to maintain telephones, there is no sufficient reason, that I can see, why they should not also contract to maintain telegraphs; in which case, so far from the established force of the Post-Office being increased, the out-door department of the telegraph branch might be reduced to any extent that the Postmaster-General saw fit. The time seems ripe for great changes in this direction.

Postal telephones are administered as follows: A householder may rent a private wire to a postoffice. He may send a message for delivery within 
a moderate distance of that office for threepence. If there is an exchange-that is, if from the post-office a number of short wires radiate to points in the town itself, or thereabout-the renter may speak, without charge, direct to a co-renter. Therefore, it only needs a local hiring of short wires by the professional men and tradesmen of a town (in other words, plenty of town renters) for the rural renter, or the rural ' call' office, to be in touch with all-with professional men, tradesmen, the post-office, police, and fire brigade.

That is what these suggestions aim at. Supplementing a cheap local parcel post and a day mail conveyed by a passenger-car, there should be, not alone in a great town here and there, but in every town, a telephone exchange, and in every village either that or a 'call' office.

In 1846, Mr. Punch, with prescient mind, foreshadowed, in his eleventh volume, some such arrangement in these words:

' Since the electric telegraph is being extended everywhere, we think it might be laid down, like the water and the assessed taxes, to every house. By these means a merchant would be able to correspond with his factors at sea-towns, a lawyer would communicate with his agents in the country, and a doctor would be able to consult with his patients without leaving his fireside.'

This, and more, is what the telephone alone can easily do. No practicable telegraph could be carried from the doctor's study to the patient's bed, and so enable them to speak mouth to ear; but with the 
telephone, under the plan described, this is feasible enough, and it could be done, too, as quickly as a messenger callș up a speaking-tube from the frontdoor to the doctor in his room.

In time, rich and populous England will learn a useful lesson from small and thinly-inhabited statesfrom Sweden and from Switzerland, from Denmark and elsewhere; for already in Sweden the Government is about to combine the telephone with the State telegraph system. In that country everybody is stated to be 'on the telephone.' This is the key of the whole situation.

England, whether urban or rural, would be a changed place-half its local troubles would vanishif that development were given to the telephone, of which it is capable. Ten years ago, in Mr. Fawcett's time, it was in London only that it was my ambition to connect every house to every profession and trade, for every conceivable purpose, even to the saving of time in avoiding fruitless social visits to people 'not at home.' Now events seem to demand a wider, indeed a national effort.

Given facilities for turning electricity readily to account as a means of communicating thought, the public eagerly avail themselves of them. Proof of this assertion is easily adduced.

In 1835, the telegraph and telephone being as yet unborn, electricity played no part as an agent of communication.

In 1855, the telegraph being well established, the 
number of messages sent by its means, at a charge, under the then prevailing tariff, of four or five shillings apiece, was about 1 million.

In 1875 , the average cost of a postal telegram being only one shilling and twopence, and private wires, for use outside the telegraph system proper, coming into vogue, the number of public and private telegraphic communications was probably as many as 40 millions.

In 1895 , the average cost of a telegram having been reduced some years previously from one shilling and twopence to about sevenpence halfpenny, the number of postal telegrams alone has risen to 72 millions.

The Post-Office having also private telephone systems, telephone companies being in active operation, and one company claiming to have transmited 279 millions of messages, it is reasonable to estimate the total number of electrical communications for the year at not fewer than 450 millions.

But this figure, so far from exhausting the probable capacity of the telephone, is but a fraction of the possible total. If, in the United Kingdom, the number of adults who, had they the chance, would use the telephone at least once in each day be put as low as five millions, then the total for the year of their transactions with it would figure at 1,825 millions.

To give rein to a reasonable enthusiasm, and assume that ten millions of adults would, if they could, use the telephone twice a day for professional 
purposes, domestic purposes, and even the details of a labouring man's daily avocations, we should reach the imposing, but still moderate, figure of 7,300 millions.

'As it is, in Great Britain,' testifies a high authority, ' there is only one subscriber to the telephone service out of every 520 people. Everywhere' [meaning abroad], he adds, 'competition is giving way to one system.' Such, in my judgment, should be, without exception, the case in England also.

Here I will stop, having demonstrated sufficiently the present comparatively limited use of the telephone and its future possibilities.

What is now wanted is a bold politician who, with firm hand, shall enforce by his eloquence and influence the acceptance of a complete scheme such as is broadly indicated here-one that, with the assent of the country, can be developed by degrees, and ultimately carried into general effect.

So the Post-Office, having in the past helped to enlarge the boundaries of commerce and encourage thrift, may, if the nation please, speedily enter on its next beneficent departure-viz., the restoration of prosperity to hamlet and homestead.

If it succeed (as if allowed to embark on the enterprise, the department is certain to do), landed proprietors may once more take heart of grace, the field-labourer return from the alley of the town to the village-green-from the tainted air of the factory 
to the pure breeze which rustles in the hedgerowsfrom loitering at the street corner to tillage of the soil. The good men do, we have been told, is oft interred with their bones. But there are exceptions, and the beneficent labours of Freeling and Hill in the distant past may yet enable others, in an early and a golden future, to reap fresh harvests on the Track of a new Mail-coach. 


\section{[ 340 ]}

\section{A P P E N DIX A.}

A Statement showing the Numbers of Postage-stamps issued during the Year ended March 31, 1895.

\begin{tabular}{|c|c|}
\hline Rate. & Numbers (ix Sixgle Stamps). \\
\hline $\begin{array}{l}\frac{1}{2} \mathrm{~d} . \\
1 \mathrm{~d} . \\
1 \frac{1}{2} \mathrm{~d} . \\
2 \mathrm{~d} . \\
2 \frac{1}{2} \mathrm{~d} . \\
3 \bar{d} . \\
4 \mathrm{~d} . \\
4 \frac{1}{2} \mathrm{~d} . \\
5 \bar{d} . \\
6 \mathrm{~d} . \\
9 \mathrm{~d} . \\
10 \mathrm{~d} . \\
1 \mathrm{~s} . \\
2 \mathrm{~s} .6 \mathrm{~d} . \\
5 \mathrm{~s} . \\
10 \mathrm{~s} . \\
£ 1 \\
£ 5\end{array}$ & $\begin{array}{r}701,353,644 \\
1,688,338,152 \\
35,178,520 \\
19,599,990 \\
56,067,720 \\
33,634,604 \\
7,173,600 \\
14,780,080 \\
5,957,700 \\
51,600,769 \\
5,137,800 \\
2,207,220 \\
10,703,140 \\
550,669 \\
309,147 \\
95,272 \\
56,438 \\
18.196\end{array}$ \\
\hline & $2,632,762,661$ \\
\hline
\end{tabular}

From the total number of 1 d. stamps, $118,800,000$ stamps, representing an amount of $\$ 495,000$, repaid by the Postal Authorities on account of postage-stamps used for fiscal purposes, must be deducted.

$£ 26,160$ is also repaid on account of stamps of higher value used fiscally. 


\section{[34I ]}

\section{APPENDIX B.}

\section{Notes to Chapter XVIII.}

THE telephone, when first introduced into this country, was regarded rather as a scientific toy than an instrument of great practical value.

It was certainly a wonderful apparatus, but imperfect. The best method of arranging a working circuit was not well understood, or, if understood, not at first generally adopted. Sounds-humming, clattering, confusing noises-imparted by induction to the private-wire circuit, interfered with the popularity of the new telegraph, even when cost was of secondary importance.

Improvements in the apparatus, secured by patent rights, made the telephone relatively an expensive luxury; but when the patents expired, prices fell, and the novel invention and its eccentricities having now become well understood and perfectly within control, the powers of the telephone are being gradually but surely appreciated.

Most forms of telegraph-eren Wheatstone's simple 'A B C' - cannot be put into the hands of an absolute novice: all require some degree of training on the part of the operator. The telephone, however, in its manipulation is simplicity itself. When about to put it in action, we lift the hearing-tubes to the ears. In sending a message we speak to the aperture, in receiving one we listen at the tubes. That is the whole process. Even an ordinary house speaking-pipe is not quite so simple to manage.

Unlike the telegraph, which, once fixed and adjusted, cannot be readily removed to another spot, the telephone may be taken about the house as easily as a chair. Left for day use in the 
hall, library, kitchen, or where not, the last duty of the housemaid at night might be to place it by her employer's bedside.

By day the master gets a cab or a messenger; he speaks with his distant office, instructs his stock-broker, or calls for articles from the chemist. The mistress orders fish, flesh, or fowl, and stores of usual or exceptional consumption, much more easily than by going to the shop or standing at her door; she can keep a dilatory dressmaker up to the mark, can make sure that this friend or that is at home for a call. All may be done without effort.

At night the doctor can be spoken with, mouth to earsymptoms described, palliatives employed under his skilled advice, his attendance summoned at any moment.

As the 'cracksman' is cutting through the plate-glass of the dining-room window, the master, listening in bed, can whisper the fact in the ear of the constable at the police-station, who is thereby enabled to secure Mr. Sikes before the householder has well got on his boots or found his thickest cudgel. An expert burglar might, it is true, cut the wire before beginning operations, but there are ways of baffling even that astute device.

As to fire, time, next to water, is the essence of extinction.

All the remarks which apply to the town residence and the use of the telephone may be urged with tenfold force in regard to a house in the country. To say the least, the telephone halves the distance; it is also true to say that it robs rural parts of their terrors.

From another point of view the telephone is essential to everyone having occasion to communicate with his neighbours -with him who has something to sell and him who desires to buy.

Even the artisan out of work may quickly find by its means where his services can be utilized; while access to the telephone of a farm-house by the labourers of the estate would be an inestimable boon in a hundred ways, and especially in cases of illness.

The policy of a private company, and probably of a Government department, is to wait for a demand before supplying it. The present aspect of affairs seems to call for more spirited 
action-such as would establish in every town, whether there is a demand for it or not, a telephonic exchange.

To do so successfully, it is obvious that there must be at least the nucleus of a system attached to the exchange, or there would be no inducement to renters to join it. An exchange with only one subscriber would be farcical. So it might become needful, for the first year, to connect a limited number of clients with the exchange at a reduced rental, or even free of charge.

That, according to my view, should at once be done all over the country, a certain number of connections with each exchange of trades and professions being guaranteed-twenty-five in one town, a hundred in another.

At the end of the year, everyone who had a purpose to serve would desire to be ' on the telephone '-the residents, because of its convenience; professional men and tradesmen, lest their earning power should fall away-and the favoured renters would have to pay full price or give up the connection.

Then the villages should be connected with the post-town; not all at once-that would be impossible-but in a sequence, to be determined by one of many simple tests.

The Postmaster-General would announce that he was prepared to connect villages with post-towns by a telephone along the postal route, on a guarantee from individuals, or the parish council, of working expenses; and simultaneously to put on a passenger mail-conveyance (a 'Bianconi' car), and carry postparcels locally at the favoured rate.

On an application being received, the details adjusted, and an agreement for a term of years being signed, the PostmasterGeneral, either by his own officers or by a telephone company acting as his agent, would construct and maintain the lines of wires. The ordinary postal processes would put in force the car and the parcel rate.

The whole procedure would be quite simple - a single district or a thousand might be taken in hand at once. They would all be independent of each other.

Then, as General Webber urges, there would be this collateral advantage-the chief, perhaps, in the official eye-the local telephones would act also as feeders to the general telegraphic and telephonic systems. 


\section{$[344$ ]}

\section{APPENDIX C}

\section{Note to Chapter IX.}

The Great Western Railway Company, it is stated, are now constructing new 'coaches' for through traffic, via the Severn Tunnel, between the North and West of England. They are $8 \frac{1}{3}$ feet wide and of the unusual length of 58 feet, and are built on steel frames, so as to prevent telescoping as far as possible in case of accident. Easiness of running is secured by mounting them on two four-wheeled bogies with a double set of hangers and springs. Each coach has seven compartments, not including that for the guard and luggage, and carries forty-eight passengers. The carriages are said to be beautifully upholstered, and decorated with coloured photographs of places of interest on the Great Western system. Each coach, which weighs 23 tons, is lighted by gas, is supplied with four lavatories and a corridor, and is to be warmed by steam. 


\section{[ 345 ]}

\section{N D E X.}

A.

Aвcherch Lane, 5, 18-20

Accelerators, 315

Accidents, Coach, 48, 233, 250, $260,262-265,278,279$

Accounts, 9-11

a penny wrong. 11

Alconbury Hill, 220-222

Alexandria, journey to, 106

Alibi, a well-planned, 84, 85

'Alphabet,' the, 183

Anchor, unusual form, 108, 109

Andover, 117, 119

Inns, 117

Apple-tree on church, 97

Appointments, old methods, 11-13

Aquatic penny post, 70,71

Arming of mail-guards, 16, 17

Army Post-Office Corps, 301, 302

Atlantic passages, 187, 188

Aust ferry, 148-150

Australian telegrams, 296. 297

Ayrton, Rt. Hon. A. S., M.P., 36

B.

Bannatyne, Dugald, 236, 237

Banning family, 11, 179, 193

Charles, 193

Barber as postman, 128

Barclay, Capt., 251, 252

Barnet and St. Albans Road, $164-166,168.170$

Bates, Cephas, 84

Barton-on-Humber, 64.66

Battle of Barnet, 172 of Hadley, 173
Beaufort, John St. L., 204-206

Beckhampton inns, 51-53

Bees in letter-box, 320

Belfast coaches, 260, 261

Beresford, Col., 302

'Bianconi' cars proposed, 328

Blunders in telegrams, 289-293

Bolventor, 1.21, 122

Boniface, C., 48, 49

Book-post, 323, 324

Boulton, G., 181

Braid, F., 239

Bridgewater Arms, the, 199, 200

Bright, Rt. Hon. John, 284

Brindisi, 107

Bristol, 146

Britannia, the, 188, 189

Browhead signal station, 274

BS BS BS V SO, 298

Bull and Mouth, the, 23, 30, 31, 37,38

Burgoyne, Sir J., 9

Burns, Sir G., Bart., 185, 187, 309,310

Bushranger, a, 63, 64

C.

Cage for evildoers, 175,176

Calvert, B., 83

Cumpania, the, at landing-stage, 193

Campbell, Capt., 57

Campden, Visct., 41

Candlestick a danger, 120, 121

Canterbury post-office, 83,84

Capern, E., 215

Cardiff, 144, 145 
Carlisle, coaches, 226-228

Inns, 226, 227

Special train run, 243

Carlyle, T., 170

Carmarthen, 122-125

Carnarvon, Earl of, 303, 304

Carrefour, 40

Cary, Sir R., 251

Cary's Road-book, 118, 153

Cat, Parliamentary vote for a, 126

Chaplin, W., 29

Charges of telegraph companies, 283,284

Chartist riots, 160

Cheating in telegraphy, 293, 294

Cherhill gang, the, 52

Chichester, Earl of, 131

Chipping Barnet, 168, 169

Christmas cards, 194

Churches :

St. Mary Woolnoth, 1, 2, 5,18

St. Mary Woolchurch Haw, 2

Shoreditch Church, 40

Holy Trinity, 67

St. Chad's, 171

Coach-journeys, discomfort of, 201,202

Coaches. See Day coaches, Fast coaches, Mail-coaches, Parcel coaches, Stagt-coaches

Collins' Line, 185

Consols, three shillings' worth of, 213

Conynghain, Marquis of, 31

Cooper, Mr., 103

Cork, 267-270

Costly practical joke, 117, 118

Cow breaking circuit, 298

Cox, J. N., 138

Cox, Newberry, 133.137

Cox, IV., mail-guard, $47,4 \mathrm{~S}$

Credit balances, 10

Crookhaven signal - station, $273-276$

Crusoe, Robinson, 104

Cunard Co., 185-189

Cunard, Sir S., Baro., 185-187

D.

Dai-y-Cantwr, 161, 162

Date-stamping, uses of, 133
Davy, Sir H., 142

Day coaches, successful, 30, 31, 181,182

Day mails for rural parts, 327 , 331,343

De Haussez, M. de, 24

Defiance coach, 250, 251

Delaval, Sir F. B., 117

De Morgan, Prof., 324

Depopulation of rural districts, 325-327

Diving feat, 151, 152

Dog as guide, 125, 126 as groom, 127

Doughall, T., 16

Dover and Calais service, 88-93 Cost of, 92, 93

Dover mail, 79 Road, 80

Drinking habits discovered, 125

Driver of last mail-coach, 98

Dublin coaches, 257, 259, 260

Duesbury, J. A., 73

\section{E.}

Early dinner (Manchester), 208

Economical telegrams, 295, 296

Edinburgh coach in snow, 46,47

Eldon, Lord, 245

Electrical communications, extent of, 337

Engine-driver, first, 243

Excavations, 2, 3

Eyre, Simon, 141

F.

Falmouth :

Indian mails, 105, 132

Green Bauk Hotel, 122

Postinaster, 133-137

Foreign ship-letters, 135

Mails, 136, 137

False mail proposed, 137

Fast coaches :

Bristol and Portsmouth, 27

Liverpool and Preston, „28, 184

(Quicksilver, 117, 119

Telegraph, 30

Sherınan's, 30, 31

Wonder, 31, $176^{\circ}$

Red Rover, 31 
Fast coaches - continued

Gloucester and Brighton, 32

Glasgow, 228

Edinburgh, 240, 241

Defiance, 250, 251

Macnamara's, 315

Fastnet Lighthouse, 274-277

Fawcett, Rt. Hon. H., M.P., 37

Fermoy, Lord, 271

'Feyther's nose,' 318

Fifty years' walking, 159

Finchley Common, 167

Finett, Sir J., 89

Finger in letter-box, 184

'Forward' letters, 316

Fourgon, a, 87, 88

Franking, 6-8

Fredericks, T., 87

Free delivery of letters (South Wales), 155, 156

Freeling, Sir F., Bart., 5, 6, 8, 20, $27,32,33,36,131,325$

Freeling, F. H., 33

G. H., 33

Frost of $1895,55,60$

Fulton, R., 91

G.

Galbraith, C., 293

Gales :

Irisb, 279

Of $1894,299,300$

Galvanized wire, 217, 218

Gay, W., 132

General Post-Office (in Lombard Street) :

Cost of maintenance, 18

Mail-guards', Comptroller's, housekeeper's rooms, 18, 19

Unpaid letter box, 19

Paid letter window, 19

Mail-coaches, 19, 20

General Post-Office at St. Martin's-le-Grand :

East, moving in, 20

The building, 21-23

West, 36, 37

North, 37

Gill, Miss, 279, 280

Gladstone, Rt. Hon. W. F., 209, 210
Glasgow, 234-239

First London mail, 234, 235

Chamber of Commerce, 235237

Postmasters, 236-239

Golden Farmer, the, 95

Granville, Mr., 274

Gravenor, IV. (post-boy), 82

Gretna, 231, 232

Green, 230, 231

Hall, 232

Grimthorpe, Lord, 174

Guards (mail), 13, 14, 16, 47-49, 262-265

H.

Hadley Highstone, 163, 170

Harley, H. O., 207

Harris, S., 229

Hat, Welshwuman's, 157, 158

Heavily-laden coaches, 250, 278

Heroism on mail-packet, 130, 131

Hicks's Hall, 39-41

Hicks, Sir B., 41

Highwaymen, 16, 52, 156, 157, $166,179,225$

(See also Robberies of the mail.)

Hill, Frederic, 229, 321

Sir Rowland, K.C.B., 36, 105, 311-318, 323, 324

Holborn Bars, 40, 42

Hoodwinking thieves, 16, 156, 157

Horne, B. W., 30

Horses :

Methodical, 123.125

Highwaymen's, 95, 166, 167

Hounds, 182, 183

Hull :

Postmen, 67-69

Post-office, 69-72

Aquatic post, 70, 71

Growth of letters, 73

Mail-coach, 74

Hulls, J., 91

Hundred-mile stages, 228

Hyde, J. Wilson, 233

Hyde Park Corner, 40

I.

Ice in Boston Harbour, 188

Ilfracombe, 143, 144 
Indian Mails :

Through France, 86-88, 105

First, 132

Indian Queen, 122

Indian telegrams, 293, 294

Inman Line, 111

Ireland :

Mail-trains in snow, 57,58

Mail-coach services, 258

Inland postage, 266

American mails, 270

' Ironclad chairs,' 292

Isle of Man :

Snow, 59, 60

Mail-service, 185

Isle of Wight packet, 100

Ivy Bush, 152-154

\section{J.}

Jackson, Mary, 159

Jamaica, danyers in, 109, 110

Jamaica Inn, 121, 122

Jarvis, J., 68, 69

Johnson's wireworks, 217

Journeys by coach, 201, 202, 228. 230

Joyce, H., C.B., 28, 129

K.

Kains, J., 108

Kaye, Mr., 22, 23

Kilkenny, 263

Killarney, 265, 266

King George passage-boat, 88, 89

Kingston-upon-Hull, 62

L.

Lambert, J. P., 108

I ambert, the diver, 151, 152

Larne steamers, 56, 57

Law of averages (an example), 112,113

Lawrence, F. .J., 33

Lefevre, G. J. Shaw, Rt. Hon., 37

Lepsius, Dr., 105

Letter-boxes at Melbourne, 320, 321

Letters :

Enclosures, 6, 7

125 miles of, 191
Liberty of St. Martin's-le-Grand, 21,22

Lichfield, Earl of, 31, 32, 116, $117,307,309$

Lifeboat telephones, 196

'Limited' coaches, 177

Liver pills, 211

Liverpool :

Mail-coaches, 177, 181-183

Mail-steamers, 185.192

Landing-stage, 192, 193

Post-office, 193-196

Postmaster, 194-196

Postal growth of business, 195

Lizard 'Town,' 115

Signal-station, 138

Loss of Mosel, 139

Local parcel post proposed, 335

London in snow, 45, 46, 54, 55

Loughor, Nanny, 158, 159

Lucan, Earl of, 304

II.

Maberly, Col., 36, 146, 306311

F. H., 230

McCulloch's views, 307, 308

MacIver, D., 187

Macnamara's coaches, 167, 315, 316

Mail-bags, 97

Mail-box, 13, 14

Mail-carts, lonely rides, 249, 250

Mail-coach office, 38

Mail-coaches :

From London, 19, 20

At St. Martin's-le-Grand, 23

Acceleration of, 24, 31, 32

Speed, 24, 25

Cost, 32

Snow, 45.49

Mail-guards. See Guards (mail)

Mail-riders, 14, 15

Mail-service contracts, 26, 27

Mail-trains in snow, $45,55-58$

Malle poste, 24

Manchester :

Mail-coach centre, 197-201

Postmasters, 204-207

Postal staff, 207

Early dinner, 208

Strange inquiries, 208-210

A poet. 215 
Marine sorting, 189, 190

Martineau, Dr., 229, 230

Mathews, C., 63, 261

Matrimonial questions, 209, 210

Mellersh, H., 104

Merewether, MIr., 52

Miller, P., 91

Mining disaster, 146, 147

Mistaken identity, 33, 34

Montagu, gallant defence of the, 130,131

Moore, G., 227

Moore (mail-guard), 48

Mosel, wreck of the, 138, 139

Mosey, Mr., 69, 71

Muffins in letter-bix, 820

Musgrave, T. M., 132

'Mushroom' anchors, 274-277

Mysterious addresses, 214, 215

\section{N.}

Nash, G., 189

Nerve, loss of, 50, 51

New York mails, 191, 192

Newcastle :

Bridges, 244-246

Bessy Surtees, 245

Postmasters, 247

Post-nffice, 247

Coaching inns, 247

Time-gun, 248

Newman, J. H., 47

Night mail-coaches, 327

Nobbs, M. J., 29, 53, 229

Norman, Capt., 130, 131

Norwood, W., 86

Nosebag by apparatus, 98

Nott, Gen. Sir W., K.C.B., 153

\section{O.}

Obelisk at Westminster, 40

Octogenarian, an, 77

One-legged postman, 68

Ord of Caithness, 250

Osbaldeston, Squire, 252, 253

\section{P.}

Page, H. R., 309

$$
\text { W., } 310
$$

Palmer, J., 5, 27, 98

Parcel coaches, 25, 94, 95
Parcels, proposed rural rates, 329 Old-time, 256, 257

Parliamentary train, 241, 242

Paterson, Mr., 91

Paterson's Road Book, 100, 118

Pat's spelling, 212

Posting, 212

Passages leading to post-offices, 70,71

Passengers by ma'l-coach, 27-29

Payne, J., S7, 88

Pellatt, G., 104

Peninsular and Oriental Company, 100, 105, 107

Penniless with a five-pound note, 144

Penny postage, practicable by coach, 312, 313

Penzance, 129, 140

Percival, J., 158

Period of mail-coaches, 243

Pickering snowed up, 58

Pillar letter-boxes, 318-320

Pincher, H. (post-boy), 83

Portskewet ferry, 148-150

Post-coaches, 177

Postal families, 11, 12

Postmaster styled 'deputy,' 104

Postmen-poets, 215, 216

Postmistresses :

An octogenarian, 77

Devonport, 120, 121

Some offices under, 132, 133

Penzance, 140

Buxton, 141

Sheffield, 202, 203

Enniscorthy, 279, 280

Postwomen, remarkable, 158,159

Preece, W. H., C.B., F.K.S., 277

Preston mail, 28, 184

Price, Ann, 158, 159

Price family, 11

Primrose Hill Tunnel, 282, 283

Printer, an old, 64

Purcell, J. S., C. B., 318

Q.

Quarantine at Southampton, 103

Queen's Hotel, 37, 38

Queenstown, 267-270

Quicksilver coach, 117, 119 
R.

Raikes, Rt. Hon. H. C., M.P., 38 Railways :

Mania, 75, 76

Surveys, 77-79

Penny postage facilitated, 312

Rebecca riots, 161

Peform Bill, 239

Reforms, slow maturity of, 17

Registered letters, 135

Retaliatio n, acts of, 140, 141

Reversing-switch, 304, 305

Rich, J. D., 194-196

Richardson, C., 151

Richmond, Duke of, 24, 31

Roach (Roche), Sir Boyle, 271

Road - measurements (starting. points), 40

Roads in South Wales, 145, 146

Robberies of the mail, $13-15,84$, 180,224

(See also Highwaymen.)

Roche's Point, 271.273

Rodmell, Mr., 68, 69

Rothschild's expresses, 82,83

Royal Mail Company, 107

Rufus Stone, 99

Rural districts, a scheme for the benefit of, 325-339

Russell, Lord John, 303

$\mathrm{S}$.

St. Albans, 174-176

St. Giles's Pound, 40

Sagg, D., 67

Salt, Sir T., 142

Sambrooke, Sir J., 170

Scotland :

Snow, 55-57

Coaches, 249.254

Severe winters, $53-55$

Severn :

Ferries, 148-150

Tunnel, 150, 151, 344

Sherborne Lane, 1,5

Sherman, E., 30

Ship-letter mails, 81, 135

Shoreditch Church, 40

Signalling at sea, 294

Sites of post-offices, 70

Smirke, Sir R., 20-23
Southampton :

Rise of trade and population, 99,102

Isle of Wight service, 100

Railway, 100, 101

Hotels, 101

Docks, 102

Postmaster and staff, 103

Steamship companies, 100 , $107,110,111$

Tragedies, 111, 112

Sovereign for three-halfpence, 214

Stage-coaches :

Dangers, 24.26

Duty on, 29

Stamps (numbers issued), 318 and

Appendix A

Standard in Cornhill, 40, 42

Stanhope, Lord, 91

Statham, Mr., 179

'Stock,' 212-214

Stone-throwing, 267

Stones End, 40

Stones, J., 68

Stow, D., 19

Sub-postinaster, a scrupulous, 288

Sub-post-offices in South IVales, 155

Surveyors, 322

Suspicious characters, 322,323

T.

Taff Vale Railway, 146

Tailors' bills, 35,36

Tanner, H., 37

'Tap' signalling, 294, 295

Taxing letters, 6

Taylor, Col. du Plat, C.B., 301

Telford, Mr., C.E., 170, 171

Telegrams :

Odd requests, 285,286

Mysterious message, 288, 289

Blunders, 289-291, 293

Cheating, 293, 294

Tap signalling, 294, 295

Economy, 295, 296

Australian, 296, 297

Ambiguous, 298, 299

Eccentric circulation, 300

Telegraph :

High rates, 283, 284

Primitive notions, 284-288 
Telegraph-continued

Without wires, $274-277,297$, 298

War, 300-303

Telephones :

A necessity, 329

Exchanges, 330, 333

Cost, 330, 333

Rural districts, 331

Postal rights, 332

Parish councils, 334

Postal wires, 334,335

Swedish system, 336

Number of messages, 337

(See also Appendix B.)

Teutonic's mail, 191

'The Mrs. Blank,' 210, 211

Thompson, Col. Raffles, 301

Tichborue Claimant, 96

Tilley, sir J., K.C.B., 18, 36, 37

Titchbourne, Chidiock, 96

Todd, A., 4

Tolls, 161

Tomtits in letter-box, 320

Trains in snowdrifts, 45,58

Tram-roads, 147, 148

Travelling post-office in snow, 58

Trollope, A., 211

Turner, Mr., 109, 110

Turnpikes, 80, 161

Turpin, R., 95

U.

Union Steamship Company, 110, 111

Unpaid postage a heavy tax, 9
V.

Viaduct at Highgate, 165

Victories, news of, 238

Villiers, Rt. Hon. C. P., M.P., 64

Vinegar an antiseptic, 19, 103

Viner, Sir R., 2-5

Volunteers from P.O. in Egypt, 302

W.

Walpole, Sir R., anecdote of, 321, 322

War-telegraphs, 300-303

Warning, a friendly, 49

Waterford, Lady, 153, 167, 168

Waterside Inn (Barton), 66

Watkins, Capt., 130, 131

Webb (mail-guard), 47

Webber, Major-Gen., R.E., C.B., 331, 333, and Appendix B

Wetherby, 12, 223, 224

Wheat, J., 64

Wheatsheaf, the, 221, 222

White, H., 14

Willatt family, 204, 205

Williams, J., 36

Williams, Mr., 103

Willock, R. P., 206, 207

Willoughby-Smith, Mr., 274

Wolff, Dr., 169

Wray, J., 70

Wreaks, Miss, 202, 203

Y.

Yates, Edmund, 106, 281, 282

Z.

Zareba, a, 302, 303

THE END.

BILLIXg AND SONS, PRINTERS, GUILDFORD. 





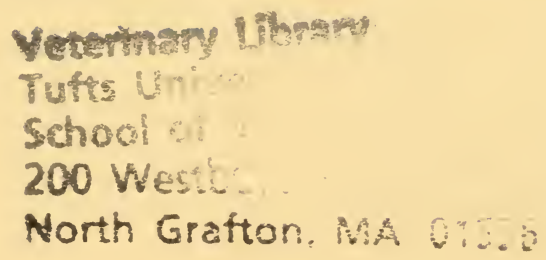


